\title{
RWE
}

Nina Möllers, Karin Zachmann (eds.)

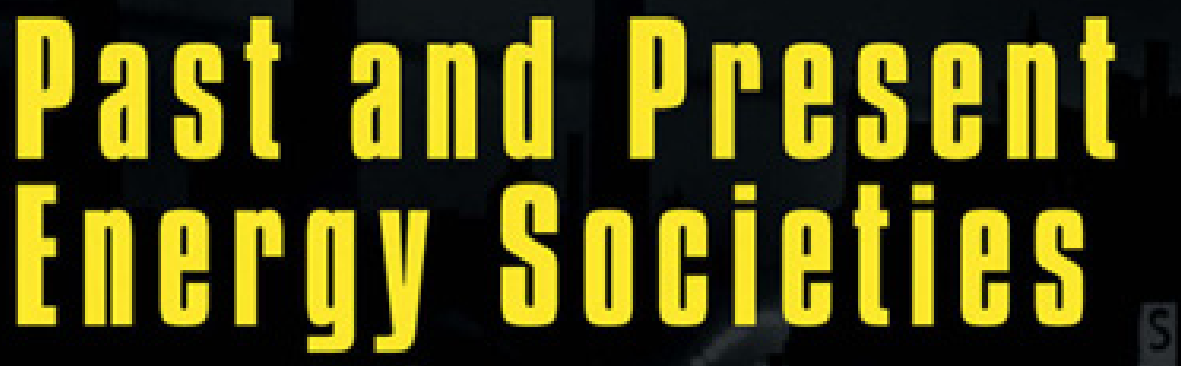

How Energy Connects Politics, Technologies and Cultures

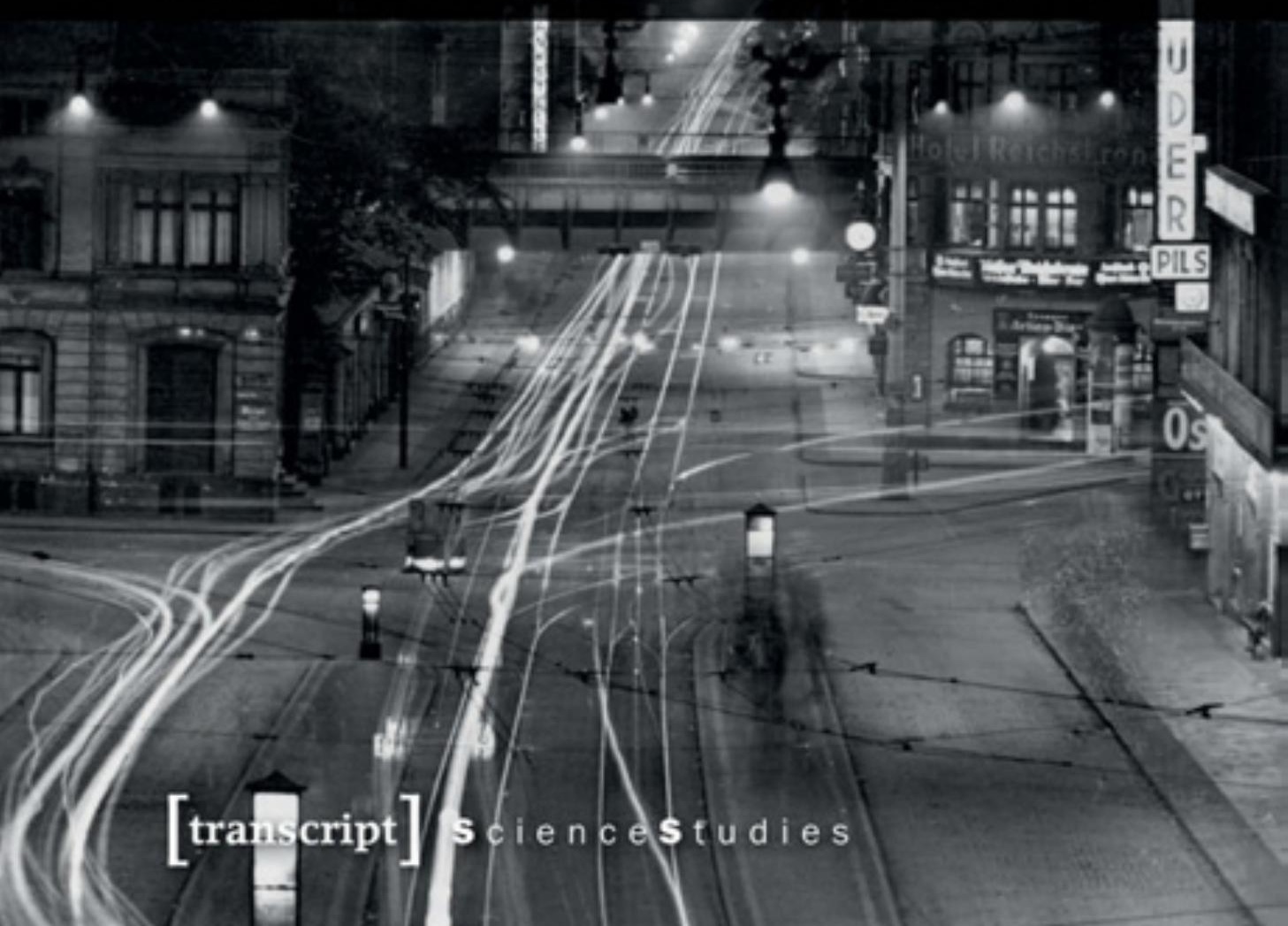


Nina Möllers, Karin Zachmann (eds.)

Past and Present Energy Societies 

Nina Möllers, Karin ZaChmann (EDS.)

\section{Past and Present Energy Societies}

How Energy Connects Politics, Technologies and Cultures

[transcript] 

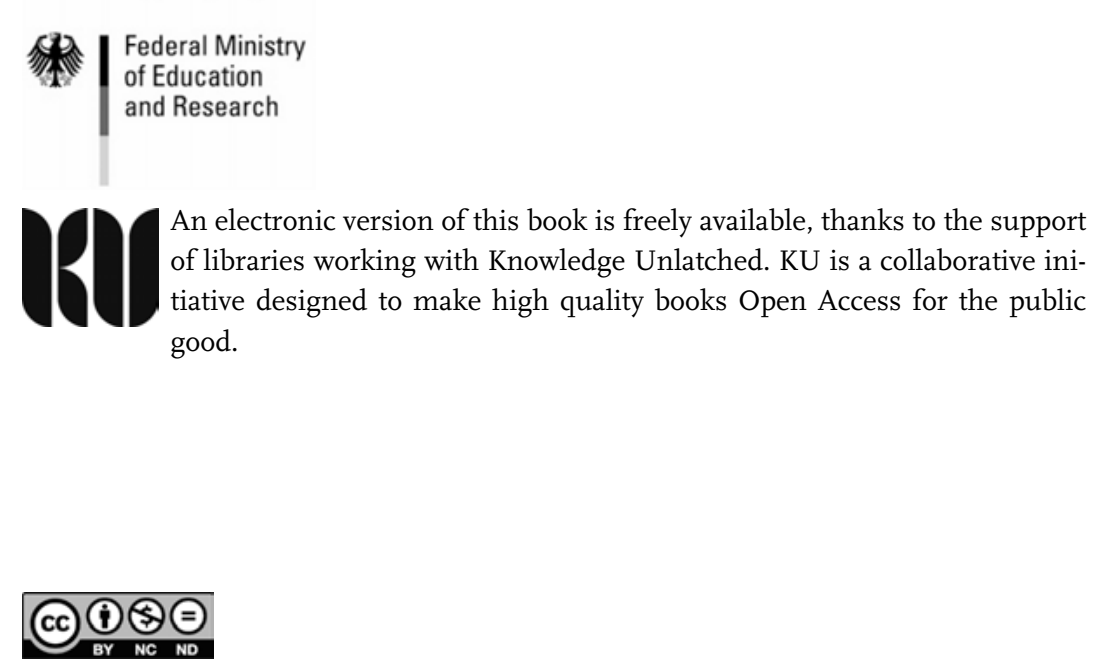

This work is licensed under the

Creative Commons Attribution-NonCommercial-NoDerivs 3.0 (BY-NC-ND).

which means that the text may be used for non-commercial purposes, provided credit is given to the author. For details go to http://creativecommons.org/licenses/by-nc-nd/3.0/.

\section{Bibliographic information published by the Deutsche Nationalbibliothek}

The Deutsche Nationalbibliothek lists this publication in the Deutsche Nationalbibliografie; detailed bibliographic data are available in the Internet at http://dnb.d-nb.de

All rights reserved. No part of this book may be reprinted or reproduced or utilized in any form or by any electronic, mechanical, or other means, now known or hereafter invented, including photocopying and recording, or in any information storage or retrieval system, without permission in writing from the publisher.

(C) 2012 transcript Verlag, Bielefeld

Cover layout: Kordula Röckenhaus, Bielefeld

Cover illustration: RWE-Stammzentrale mit Leuchtreklame, Essen, um I930

Source: Historisches Konzernarchiv RWE

Typeset by Katharina Lang, Bielefeld

Printed by Majuskel Medienproduktion GmbH, Wetzlar

Print-ISBN 978-3-8376-1964-5

PDF-ISBN 978-3-8394-I964-9 


\section{Inhalt}

Past and Present Energy Societies

How Energy Connects Politics, Technologies and Cultures

Karin Zachmann | 7

\section{Cultural Representations of Energy}

\section{Electrifying the World}

Representations of Energy and Modern Life at World's Fairs, 1893-1982

Nina Möllers | 45

"We want to live electrically!"

Marketing Strategies of German Power Companies in the $20^{\text {th }}$ Century

Sophie Gerber | 79

Filming Electrical Consumption

EDF's Promotional Films (1946-2004)

Yves Bouvier | 109

\section{Energy Consumption Practices}

\section{Managing Energy Consumption}

The Rental Business for Storage Water Heaters of Berlin's Electricity

Company from the Late 1920 s to the Early 1960 s

Nina Lorkowski | 137 


\section{Saving Energy by Shifting Clocks?}

Energy Policy and the Introduction of Daylight Saving Time in East and West Germany

Mathias Mutz | 163

\section{Energy Consumption Practices and Social Inequality}

The Case of Low-Income Households

Karl-Michael Brunner, Anja Christanell, Markus Spitzer | 195

\section{Societal Perceptions of Energy Resources}

\section{Cultural Meanings of Wood Gas as Automobile Fuel}

in Sweden, 1930-1945

Helena Ekerholm | 223

\section{Missing Green in the Black Gold}

Environment in the Public Debate on West Siberian Oil Production from the 1970s to the Present

Valentina Roxo | 249

\section{Publics in the Pipeline}

On Bioenergy and its Imagined Publics in Norway and Sweden

Tomas Moe Skjølsvold | 277

\section{Patterns of Energy Transitions}

The Long-Term Role of Energy in the Economic Growth of Europe

Silvana Bartoletto | 305

\section{Authors | 331}

Figures and Tables | 335 


\title{
Past and Present Energy Societies
}

\author{
How Energy Connects Politics, Technologies and Cultures
}

\author{
KARIN ZACHMAN N
}

\section{An Introduction}

"Where were you when the lights went out?" With this short, pointed question, David Nye opened his book on the history of electricity blackouts in America. ${ }^{1}$ These few words sufficed to set his program, namely to explore blackouts not as technical failures but social constructions. Thus, he used sudden darkness to illuminate the political, technological and cultural dynamics of high-energy societies.

In the studies that follow, we are pursuing a similar aim but with a different angle. To investigate how energy concatenates politics, technologies and cultures, we invited researchers from different fields in the humanities and social sciences to discuss energy as a resource, a symbol and a consumer good. ${ }^{2}$ We focussed attention on a variety of sites in Europe and the United States and travelled not just through space but also through time - from the $19^{\text {th }}$ to the $21^{\text {st }}$ century - in order to understand how energy was perceived, appropriated and put to use for a broad variety

1 | David E. Nye: When the Lights Went Out. A History of Blackouts in America. Cambridge, MA: MIT Press 2010, 1.

2 | The contributions in this volume are based on papers given at the international workshop "Deified - Damned - Depleted: Energy as Symbol, Resource and Consumer Good", organized by the research project "Objects of Energy Consumption" at the Deutsches Museum, January 20-22, 2011. We thank the Federal Ministry of Education and Research (BMBF) for the generous funding of the research project, the workshop and this publication. 
of purposes. Presenting here the findings from these studies, we hope to contribute new perspectives on past and present energy societies.

At the outset, however, such an undertaking encounters a major difficulty. This is the problem of finding a comprehensive and definitive concept of energy, not just in the sciences but in technology and culture. In science, the physicist and Nobel laureate Richard Feynman once stated in one of his famous lectures in the 1960s: "It is important to realize that in physics today, we have no knowledge of what energy is. We do not have a picture that energy comes in little blobs of a definite amount." 3 There are, of course, formulas to calculate a numerical quantity that is always constant. But according to Feynman, this numerical quantity is an abstract thing that tells us nothing about the mechanisms and reasons for the different formulas. ${ }^{4}$ Other scholars from a broad spectrum of fields - including more Nobel laureates - advanced the idea of energy as an all-encompassing concept. This becomes obvious in the introduction of physicist R. Bruce Lindsay's history on the concept of energy: "No other concept [than the idea of energy, K.C.Z.] has so unified our understanding of experience. Without exaggeration we can say that every single aspect of human experience, whether it be what we observe in the external world, or what we do or what is done to us, can be adequately described either as a transfer of energy in one form from one place to another or the transformation of energy from one form to another." 5 But also Lindsay ends up asking: "But what is the thing that is transferred and transformed?" He consulted encyclopaedias and dictionaries but to no result. Fighting resignation, he asked: "Must you then pursue a whole course of university physics with its awful array of mathematical symbolism in order to understand what energy means, how it is measured, and the reason for its overwhelmingly important role in human life?"6 Lindsay suggests instead trying another approach, namely to detect the key idea in energy. Thus, from a philosophical perspective he

3 | Richard P. Feynman, Robert B. Leighton, Matthew Sands: Feynman Lectures on Physics: Mainly Mechanics, Radiation, and Heat. 3 vols. Reading, MA: Addison-Wesley, 1966, 59.

4 | Feynman: Feynman Lectures on Physics, 59.

5 | R. Bruce Lindsay: Energy. Historical Development of the Concept. Stroudsburg, PA: Dowden, Hutchinson \& Ross, 1975, 2.

6 | Lindsay: Energy, 5. 
characterized energy as "constancy in the midst of change." 7 This short assertion effectively translates the first law of thermodynamics (that energy is 'conserved') into a philosophical statement that is broad enough to guide Lindsay's exploration on how energy emerged as a concept in history.

Scholars and intellectuals in the social sciences, however, differ from physicists because they are not so much interested in exploring what is constant but rather in seeking explanations of change. In doing so, well-known academics contributed to what has become known as the 'energy-civilization equation', i.e. a train of thought that deduced societal achievements (civilization) from increases in energy consumption. ${ }^{8}$ "Because we use a hundred and ten times as much coal as our ancestors, we believe ourselves a hundred and ten times better, intellectually, morally, and spiritually." 9 This is how Aldous Huxley, author of the dystopian novel Brave New World (1932), satirically presented the energy-civilization equation that many other writers and thinkers assumed was a valid construct. Radical innovations, such as the steam engine, the internal combustion engine, and the dynamoelectric machine, fundamentally changed existing energy regimes and led to the development of thermodynamics, the basic formulation of the relationship between work and energy in Newtonian physics, and the establishment of the first and second laws. Together, they also inspired scholars to define energy as the driving force throughout human history that is responsible for all changes.

That energy might fundamentally drive history is the central premise of this introduction. As a first step, it will outline, albeit briefly, how the deterministic tradition of a societal energetics emerged and changed against the background of energy transitions and societal evolutions. Contextualizing and historically grounding the developing energycivilization equation will, it is hoped, provide us with the means to understand that the challenges of the pending energy transitions of the $21^{\text {st }}$ century require a more reflective picture on the complex relationship between energy and society. This introduction then goes on to introduce

7 | Lindsay: Energy, 5.

8 | For an overview see George Basalla: "Energy and Civilization”, in: Chauncey Starr/Philip C. Ritterbush, eds. Science, Technology, and the Human Prospect: Proceedings of the Edison Centennial Symposium. New York: Pergamon Press, 1980, 39-52.

9 | Aldous Huxley: “Progress”, in: Vanity Fair 29 (1928), 69. 
the anthology's chapters and to show how the authors approach past and present energy societies and thus contribute new perspectives on the linkages between energy, politics, technologies and cultures.

\section{Revisiting the Energy-Civilization Equation}

Many writers in $19^{\text {th }}$ century Great Britain attributed the country's becoming 'the workshop of the world' and the then wealthiest nation to the advent and expansion of steam power. ${ }^{10}$ The technical and popular literature on the European continent replicated this deterministic energy-civilization view in many versions. But early on we can also find a critical stance against this formulation. Although his statement, "The hand-mill gives you society with the feudal lord; the steam-mill society with the industrial capitalist," is often interpreted as proof for the assumption that Karl Marx (1818-1883) subscribed to the energy-civilization equation ${ }^{11}$, Marx explicitly contradicted this view in the chapter on machinery and big industry in the first volume of Capital. ${ }^{12}$ Here he maintained that not the steam engine bore the responsibility for the industrial revolution but rather the machine tool. "The machine proper is therefore a mechanism that, after being set in motion, performs with its tools the same operations that were formerly done by the workman with similar tools. Whether the motive power is derived from man, or from some other machine, makes no difference in this respect."13 Others, however, were more impressed by the power of steam and subsequent heat engines.

10 | For details cf. Basalla: "Energy and Civilization", 42-43.

11 | Karl Marx: The Poverty of Philosophy. Chapter 2, Second Observation, http://www.marxists.org/archive/marx/works/1847/poverty-philosophy/ch02. htm, Accessed 28.12.2011.

12 | In the online edition, the chapter on "Machinery and Modern Industry" is chapter 15. Cf. Karl Marx: Capital. A Critique of Political Economy, Volume One. Chapter 15: Machinery and Modern Industry. Section 1 - The Development of Machinery. http://www.marxists.org/archive/marx/works/1867-c1/ch15.htm, Accessed 28.12.2011.

13 | Shortly thereafter Marx stated again: "The machine, which is the startingpoint of the industrial revolution, supersedes the workman, who handles a single tool, by a mechanism operating with a number of similar tools, and set in motion 
The British philosopher and sociologist Herbert Spencer (1820-1903) subscribed to the energy-civilization equation when he reasoned that energy is largely responsible for material differences between societies. ${ }^{14}$ The more energy a society could harness from its resources, the better it fared relative to others. Based on his notion of physical power, Spencer conceived society as an energetic system. He interchangeably used metaphors of power, energy and force for developing his concept of societal evolution. Surprisingly, however, Spencer did not deal with the social use of nonhuman energy forms. ${ }^{15}$ That remained for Sir Patrick Geddes (1854-1932) who built on Spencer but advanced the use of non-human energy to become a main argument for explaining societal evolution. A Scottish biologist, sociologist, and city planner who co-founded the British Sociological Society in 1902 and strove to develop a concrete and applied sociology of cities that he called "civics", Geddes subdivided the industrial era into a 'paleotechnic' and a 'neotechnic' phase. He distinguished 'paleotechnics', "a comparatively crude and wasteful technic age, characterised by coal, steam, and cheap machine products, and a corresponding quantitative ideal of 'progress of wealth and population'" from 'neotechnics', "a finer civilisation, characterised by the wider command, yet greater economy of natural energies, by the predominance of electricity, and by increasing victory of an ideal of qualitative progress, expressed in terms of skill and art, of hygiene and education, of social polity, etc."16 Geddes shared his admiration of electricity as an agent of societal betterment with many others. But his specific, energy-based framework of societal as civic evolution would find just one important intellectual heir, whom I will introduce later.

by a single motive power, whatever the form of that power may be." Marx: Capital, Section 1 - The Development of Machinery.

$14 \mid$ Herbert Spencer: First Principles. New York: A. L. Burt, 1880.

15 | Cf. Andrew M. McKinnon: “Energy and Society: Herbert Spencer's 'Energetic Sociology' of Social Evolution and Beyond”, in: Journal of Classical Sociology 10:4 (2010), 439-55.

16 | Patrick Geddes: "Civics: As Concrete and Applied Sociology, Part II", in: Sociological Papers 2 (1906), 58-119, available at http://www.gutenberg.org/ files/13205/13205-h/13205-h.htm, Accessed 28.12.2011. See also Patrick Geddes: Cities in Evolution: An Introduction to the Town Planning Movement and the Study of Civics. London: Williams \& Norgate, 1915, Chaper IV. 
Similar to Geddes but framed in terms of a cultural theory, his German contemporary, the chemist and Nobel laureate Wilhelm Ostwald (18531932) established energy as the core concept of his world view. Ostwald argued that the transformation of crude energy (rohe Energie) into useful energy (Nutzenergie) was at the base of all social change. ${ }^{17}$ According to Ostwald, the efficiency of this transformation (Güteverhältnis) determines the amount of free energy that societies can put to use for cultural work. This then would be the second principle of energetics. While the first principle is the first law of thermodynamics (i.e. conservation of energy), the second principle serves as a guideline of cultural development. ${ }^{18}$ Ostwald concluded his energy-deterministic worldview with the firm appeal, "Do not waste energy!" which he ambitiously called the energetic imperative. ${ }^{19}$ Ostwald's reasoning on the role of energy in society provoked criticism from, among others, Max Weber, who accused Ostwald of deriving value judgements from hard science and thus adhering to a naturalism that does not foster but prohibit a fruitful discussion between the hard and the cultural sciences. ${ }^{20}$

But Ostwald inspired other thinkers to expand on his ideas of energetics. One of them was the U.S. American historian and writer Henry Adams (1838-1918), who expanded his notion of energy beyond the concept of physics. In his famous 1900 essay “The Dynamo and the Virgin”, Adams developed a multi-stage theory of Western civilization that was based on energy. He differentiated four stages of increasingly shorter length, what he saw as proof of a historical process of acceleration. The first stage was driven by religious energy embodied in the Virgin Mary. This stage lasted until around 1600 . The next stage was marked by the coming of the steam engine and led into the age of mechanical energy that lasted for the next 300 years. In 1900, symbolized by the spectacle of the dynamoelectric machine, the age of electricity supplanted the mechanical stage, but it lasted only 17 and a half years. By 1917, the ether that filled the whole

17 | Wilhelm Ostwald: Energetische Grundlagen der Kulturwissenschaft. Leipzig: Klinkhardt, 1909, 24.

18 | Ostwald: Energetische Grundlagen, 39.

19 | Wilhelm Ostwald: Der energetische Imperativ. Leipzig: Akademische Verlags-Gesellschaft, 1912.

20 | Max Weber: “Energetische Kulturtheorien”, in: Gesammelte Aufsätze zur Wissenschaftslehre. Tübingen: Mohr, 1968, 400-26. 
universe would emerge as the only still available source of energy, but the emergent ethereal civilization was doomed to perish by 1921. Assuming that the universe relied on a fixed supply of energy, Adams expected an apocalyptical end of history due to the law of entropy. ${ }^{21}$

At the same time as Adams published his dystopian visions, other scholars also warned of the limited availability of usable energy stemming from the second law of thermodynamics. The British chemist and Nobel laureate Frederick Soddy (1877-1956) was among them. In his 1912 book Matter and Energy, Soddy stated that the "laws expressing the relations between energy and matter are not solely of importance in pure science, [but] they [also] necessarily come first in order [...] in the whole record of human experience, and they control, in the last resort, the rise and fall of political systems, the freedom or bondage of nations, the movements of commerce and industry, the origin of wealth and poverty, and the general physical welfare of the race." ${ }^{22}$ As a pioneer in the study of the atom, however, Soddy turned from pessimist into an anxious protagonist of atomic energy. Releasing the energy in the heart of the atom would allow humankind to escape the danger inherent in the scarcity of coal (and oil) and instead bring about an affluent paradise of the atomic future. ${ }^{23}$ Thus, roughly three decades prior to the euphoric though sometimes ambivalent assessment of the atom during the Cold War, Soddy preached on the promise of abundance that would be based on atomic energy. He also pondered the possibility of producing atomic weapons. Similarly, science fiction writer H. G. Wells foresaw the danger of atomic warfare and developed the vision that humankind would be able to use the atom peacefully only after having gone through a devastating atomic war. Wells dedicated his novel, written

21 Henry Adams: The Education of Henry Adams. Boston: Houghton Mifflin, 1961, chapters 25 and 33, quoted in David Nye: Electrifying America. Social Meanings of a New Technology, 1880-1940. Cambridge, MA: MIT Press 1997, 143.

22 | Frederick Soddy: Matter and Energy. London: Williams and Norgate, 1912, 10-11, quoted by Leslie A. White: The Evolution of Culture: The Development of Civilization to the Fall of Rome. New York: McGraw-Hill, 1959, 39.

23 | Frederick Soddy: Science and Life. New York: E. P. Dutton, 1920, 22-24; Frederick Soddy: Wealth, Virtual Wealth and Debt. London: George Allen and Unwin, 1926, 49-68. 
before the beginning of World War I, to none other than Frederick Soddy. ${ }^{24}$ The chemist Soddy saw a second impediment to the arrival of his atomic 'Garden Eden'. This was the prevailing economic system. Therefore, he turned to economics and called for a major change in the economic system that would be based on the laws of thermodynamics. ${ }^{25}$

While Soddy derived his optimism for the future of humankind from his faith in the still-to-be-tapped mighty atom, many of his contemporaries in the first third of the $20^{\text {th }}$ century focussed their hopes for a better future on electricity as a clean form of energy. Scientists, engineers, intellectuals, entrepreneurs, feminists, politicians - in short, representatives of all strata of society from many countries - expected to better society via electrification. ${ }^{26}$ One of them was Vladimir Ilyich Lenin, leader of the communist revolution in Russia, who pushed electrification because he believed that the power of Soviets plus electrification would lead toward true communism. ${ }^{27}$ British feminists cherished quite comparable hopes when they formed an Electrical Association for Women as a step toward their emancipation. ${ }^{28}$ In the United States during the Great Depression, leaders of the New Deal and their followers championed the electrification of the Tennessee Valley as a means to bring the backward South into the $20^{\text {th }}$ century. ${ }^{29}$ Even before the turn of the century in Germany, representatives of the conservative as well as the socialist political camp connected their societal visions to the availability of electricity, not just as a power source but as a source for empowerment of their respective clienteles. Socioconservative economists as well as engineers hoped to secure the survival

24 | Basalla: “Energy and Civilization”, 47.

25 | Soddy: Wealth, Virtual Wealth and Debt, 49-68.

26 | For an early review of this literature, see James W. Carey and John J. Quirck: "The Mythos of the Electronic Revolution", in: The American Scholar, Parts I and II, 39 (1970), 219-41, 395-424.

27 | On Lenin and Soviet electrification, see Jonathan Coopersmith: The Electrification of Russia, 1880-1926. Ithaca, NY: Cornell University Press, 1992.

28 | Carroll W. Pursell, Jr.: "Domesticating Modernity: The Electrical Association for Women, 1924-1986", in: British Journal for the History of Science 32:1 (1999), 47-67.

29 | Thomas P. Hughes: American Genesis: A Century of Invention and Technological Enthusiasm. New York: Viking, 1989, 353-81; Nye: Electrifying America, 304-35. 
of small-scale industries and traditional crafts against the competition of big industry by introducing small-scale electrical engines as power source. ${ }^{30}$ At the same time, the socialist leader August Bebel (1840-1913) extended and republished his socialist utopia under the title, The Woman and Socialism, in several editions. Therein, he envisioned the electrification of the household as the precondition for the emancipation of women, and he described his socialist utopia in terms of an electrified paradise. ${ }^{31}$

German engineers also felt empowered as innovators in the field of electric power generation, its transmission, and its use to minimize the effects of entropy, thus following Ostwald's energetic imperative. ${ }^{32}$ The engineers called for superseding the principle of profitability by the principle of efficiency, as the latter was the most important regulator of the

30 | Ulrich Wengenroth: “Motoren für den Kleinbetrieb. Soziale Utopien, technische Entwicklung und Absatzstrategien bei der Motorisierung des Kleingewerbes im Kaiserreich", in: Ulrich Wengenroth, ed. Prekäre Selbstbestimmung. Zur Standortbestimmung von Handwerk, Hausindustrie und Kleingewerbe im Industrialisierungsprozess. Stuttgart: Steiner, 1989, 177-205. In the U.S., ironically, Henry Ford became a champion of decentralized "village industries" even though his company's Highland Park and River Rouge factories epitomized the very essence of mass production. See Howard Segal: Recasting the Machine Age: Henry Ford's Village Industries. Amherst: University of Massachusetts Press, 2005. The German inventor Rudolph Diesel strongly believed that his new engine possessed all the right characteristics to decentralize factory motive power, thereby mitigating many of the negative aspects of the factory system, which he believed could be attributed to the steam engine and its centralized power distribution system (belts, pulleys, and line shafting that conveyed power to manufacturing processes, machine tools, textile machinery, and the like from a central source). See Diesel's discussion in his Diesel's Rational Heat Motor: A Lecture. New York: Progressive Publishing Company, 1897, 18.

31 | August Bebel: Die Frau und der Sozialismus. 37 th ed. Stuttgart: Dietz, 1904.

32 | Hans Dieter Hellige: “Wirtschafts-, Energie- und Stoffkreisläufe in säkularer Perspektive: Von der thermodynamischen Entzauberung der Welt zur recyclingorientierten Wachstumsgesellschaft", in: Gangolf Hübinger/Ernst Schulin, eds. Universalgeschichte und Nationalgeschichten. Freiburg im Breisgau: Rombach, 1994, 291-315. 
economy. ${ }^{33}$ In comparison to the economist, the engineer would act as the superior housekeeper as he calculated efficiencies based on the inputs and outputs of energy in his works. ${ }^{34}$ This would entitle engineers to be the leaders of society because only they knew best how to govern the economy and society in the most efficient way. ${ }^{35}$

Similar ideas also sprang up in the United States. In 1921, social scientist Thorstein Veblen (1857-1929) proposed a Soviet of Technicians, which would be more competent in managing the country's industrial system than what he termed Vested Interests and their absentee owners. ${ }^{36}$ Rather than the wasteful, highly inefficient management of industry by the financial agents of absentee owners, the Soviet of Technicians would responsibly govern the allocation of energy sources, equipment, materials, and manpower. Led by the self-trained and self-styled 'Bohemian engineer' Howard Scott, subscribers to Veblen's Engineers and the Price System soon envisaged a new currency to replace money, a currency based on energy instead of gold. Although the Veblen-inspired movement flowered only briefly as “Technocracy, Incorporated", energy-based technocratic thought endured in many forms, including the ideas implicit in onetime Technocracy, Inc. member M. King Hubbert (of 'Hubbert's Peak' or

33 | The most explicit conclusion drew Rathenau and Moellendorff when they required reforming the post WWI economy according to the principles of the warfare state into a social economy where the market was replaced by organization for the sake of efficiency. Cf. Karin Zachmann: “Wirkungsgrad contra Wertgrad: Zur Entstehung des Konflikts zwischen der technischen und der ökonomischen Auffassung vom Wirtschaften”, in: Technikgeschichte 62:2 (1995): 103-31.

34 | Julius Schenk: Die Begriffe Wirtschaft und Technik und ihre Bedeutung für die Ingenieurausbildung. Breslau: Preuss \& Jünger, 1913.

35 | On the engineers' claim to societal leadership after WWI see Charles Maier: "Zwischen Taylorismus und Technokratie: Gesellschaftspolitik im Zeichen industrieller Rationalität in den zwanziger Jahren in Europa”, in: Michael Stürmer, ed. Die Weimarer Republik. Belagerte Civitas. Königstein: Athenäum, 1985, 188213; Karin Zachmann: Mobilisierung der Frauen. Technik, Geschlecht und Kalter Krieg in der DDR. Frankfurt/Main: Campus, 2004, 136-49.

36 | Thorstein Veblen: The Engineers and the Price System. Kitchener, ON: Batoche Books, 2001 [1921], available at http://socserv.mcmaster.ca/econ/ ugcm/3II3/veblen/Engineers.pdf, Accessed 28.12.2011. 
'peak oil' fame) and the historical framework put forward in 1934 by the American 'public intellectual' Lewis Mumford (1895-1990). ${ }^{37}$

In the early 1930s, Mumford subscribed to Veblen's diagnosis and critique of an increasing "dissociation between capitalism and technics." 38 In his widely-read fundamental work Technics and Civilization, published in 1934, Mumford explored the development of the technology-driven Western civilization. By expanding the framework of Geddes, whom he praised as his master, Mumford differentiated three historical epochs that had formed technologically distinct complexes. A determining factor for each epoch was energy. The ecotechnic phase was dominated by water power and wood energy sources. The paleotechnic phase was characterized by a coal-based energy system. The neotechnic phase, eventually, rested upon the modern electricity-based energy complex. Mumford analyzed the social effects of new power sources and technologies in great detail and he shared his contemporaries' overly enthusiastic vision of the social effects of electricity. ${ }^{39}$

The advent of atomic power and its ambivalent perception as both cornucopia and sword of Damocles in the fiercely contested Cold War

37 | On the technocracy movement, see Daniel Bell: The End of Ideology. New York: The Free Press, 1960; Edwin T. Layton, Jr.: Revolt of the Engineers. Cleveland, OH: Case Western Reserve University Press, 1971; Henry Elsner, Jr.: The Technocrats: Prophets of Automation. Syracuse, NY: Syracuse University Press, 1967; William E. Akin: Technocracy and the American Dream: The Technocrat Movement, 1900-1941. Berkeley: University of California Press, 1977; and Howard Scott's own, infamous "Hotel Pierre" address of January 1933, "Technocracy," available online at http://www.technocracy.org/technical-alliancetn/ howard-scott/208-societyscott, Accessed 28.12.2011. On Hubbert, see Ronald Doel's biographical sketch in the Handbook of Texas Online, http://www.oilcrisis. com/hubbert/bio_doel.htm, Accessed 28.12.2011. On the American and the German technocracy movement in comparison see Stefan Willeke: Die Technokratiebewegung in Nordamerika und Deutschland zwischen den Weltkriegen. Frankfurt/ Main: Lang, 1995.

38 | Lewis Mumford: Technics and Civilization. New York: Harcourt, 1934, 366.

39 | Near the end of Technics and Civilization, albeit briefly, Mumford even projected a future "biotechnic" phase that some analysts have seen as Mumford's vision of a more sustainable socio-technic energy regime. Mumford: Technics and Civilization, 353. 
nourished new thinking about the energy-civilization equation. The American anthropologist Leslie A. White (1900-1975) initiated this renewed discussion in the midst of World War II with the publication of his influential article "Energy and the Evolution of Culture" in The American Anthropologist. Leslie asserted that anthropology was a "branch of natural science which deals with matter-and-motion, i.e. energy, phenomena in cultural form, as biology deals with them in cellular, and physics in atomic form." ${ }^{\circ}$ White established himself as an evolutionist against the anthropological school of Franz Boas by tying cultural evolution to human control of energy. Cultural evolution was to be measured by the amount of energy the culture in question was able to harness. As White explicitly stated: "The key to the future, in any event, lies in the energy situation. [...] Should [...] the amount of energy that we are able to harness diminish materially, then culture would cease to advance or even recede." ${ }^{11}$ That the great civilizations of China, India, Egypt, the Near East, Central America, and Peru had failed to advance after a phase of rapid development, White attributed to their limitations in the availability of energy. With respect to the future, he was optimistic, as he counted on tapping of new sources of energy, including atomic energy, which he saw as the most intriguing possibility. ${ }^{42}$ If the technology of nuclear fission succeeded, the energy resources would be multiplied a thousand fold. Even if nuclear energy were to fail, White's optimism remained steadfast because, he underscored, "there is always the sun." He expected that the sun could become the direct and thus chief source of power in the future. ${ }^{43}$ In 1959, with civilian nuclear energy - i.e. 'the Peaceful Atom' - well on its way toward realization, White extended his 1943 cultural energetics framework into a book-length exploration of the evolution of culture to the fall of Rome. He meant the book to be the first of a three-volume project examining the evolution of cultures over all historical epochs. That energy was the main variable in his explanatory framework becomes especially clear from the announced

40 | Leslie A. White: "Energy and the Evolution of Culture", in: American Anthropologist 43:3 (1943), 335.

41 | White: "Energy and the Evolution of Culture", 350.

42 | White: "Energy and the Evolution of Culture", 350.

43 White: "Energy and the Evolution of Culture", 351. 
content of his planned second book, tentatively titled "The Fuel Revolution and Its Institutional Concomitants." 44

Four years before Leslie White published The Evolution of Culture, the American sociologist Frederick W. Cottrell (1903-1979) put another version of the energy-civilization equation on the book market, Energy and Society. The Relation between Energy, Social Change, and Economic Development (1955). In the midst of the intense competition between two political, economic, and social systems that constituted the Cold War, Cottrell aimed at discovering "the relations between the energy converters and fuel men use and the kinds of society they build." 45 This could help to evaluate the competing systems' claims on the betterment of humankind, as the possibilities of change would not only rest on human beings' values but also on knowledge of their physical potentialities. Cottrell stated that energy was the key to determine - or unlock - these potentialities: "It is that the energy available to man limits what he can do and influences what he will do." ${ }^{6}$ Departing from this thesis, he differentiated 'low-energy societies' from 'high-energy societies' and explored in great detail societal changes that followed from the transition to high-energy converters. His book, however, was not well received and was unfavourably reviewed by anthropologists, especially the followers of Leslie A. White. Marshall Sahlins, a former student and then colleague of White, accused Cottrell of an inadequate theory of cultural change, as Cottrell put values at the centre of his explanation of cultural change but at the same time let cultural change determine values. This not only prevented energy determinism but also prohibited "a satisfactory explanation of the origins of energy-based changes." 47 Cottrell himself came to the same conclusion, as he wrote, "perhaps the contribution of this essay lies chiefly in the fact that it suggests whole areas of ignorance whose exploration might increase the accuracy of thinking about the future development of human society." ${ }^{8}$ However, Cottrell's framework of

44 | White: The Evolution of Culture, $\mathrm{x}$.

45 | Frederick W. Cottrell: Energy and Society: The Relation between Energy, Social Changes, and Economic Development. New York: McGraw-Hill, 1955, 3.

46 | Cottrell: Energy and Society, 2.

47 | Marshall D. Sahlins: "Energy and Society: The Relation between Energy, Social Change, and Economic Development. W. Frederick Cottrell”, in: American Anthropologist 58:6 (1956), 1143.

48 | Cottrell: Energy and Society, 311. 
thinking in terms of a low-energy and a high-energy society based on the energy converters and the fuels that had been used proved to be a useful concept to several engineer-historians in the United States and was taken up by subsequent researchers such as Vaclav Smil.

The energy crisis of the 1970s brought to the fore a more critical perspective on the energy-civilization equation. The Romanian-born U.S. economist Nicholas Georgescu-Roegen (1906-1994) published The Entropy Law and Economic Process in 1971 where he criticized the mainstream economists for not recognizing the entropy law with its consequences for economic growth. ${ }^{49}$ In his book, Georgescu-Roegen laid the groundwork for the concept of a steady-state-economy that was further developed by his student Herman Daly. The latter defined such an economy as "an economy with constant stocks of people and artefacts, maintained at some desired, sufficient levels by low rates of maintenance 'throughput', that is, by the lowest feasible flows of matter and energy from the first stage of production to the last stage of consumption." 50 The idea of a steady state can be traced further back in history. Daly referred extensively to the $19^{\text {th }}$ century British economist John Stuart Mill to gain credit for GeorgescuRoegen's and his concept. Its prominence in the late 1970s, however, emerged from the coincidence of the environmental movement with the energy crisis..$^{51}$

49 | Nicholas Georgescu-Roegen: The Entropy Law and Economic Process. Cambridge, MA: Harvard University Press, 1971.

50 | Herman E. Daly: Steady-State Economics. San Francisco: Freeman, 1977, 17.

$\mathbf{5 1}$ | Not only would the work of Herman Daly build on and advance GeorgescuRoegen's fundamental ideas, but so would the scholarship of Kozo Mayumi. See Kozo Mayumi: The Origins of Ecological Economics: The Bioeconomics of Georgescu-Roegen. London: Routledge, 2001. To a large extent, the more vocal, nonscholarly publications of Jeremy Rifkin rely on Georgescu-Roegen's work. Cf. e.g. Jeremy Rifkin: Entropy. A New World View. New York: The Viking Press, 1980 or more recently Jeremy Rifkin: The Third Industrial Revolution: How Lateral Power is Transforming Energy, the Economy, and the World. London: Palgrave MacmilIan, 2011. On the history of the energy crisis of the 1970s, see Karen R. Merrill: The Oil Crisis of 1973-1974: A Brief History with Documents. Boston: Bedford/ St. Martin's, 2007 and Jens Hohensee: Der erste Ölpreisschock 1973/74. Stuttgart: Steiner, 1996. On the history of the ecological movement of the 1960 s and 
The no-growth concept gave the energy-civilization equation new meaning as it questioned the hitherto commonly held assumption that societal progress is bound to energy-fuelled economic growth. By contrast, anti-growth scenarios called for human-scaled and decentralized technological cultures that would reduce the dependency on high-energy converters. The American physicist Amory B. Lovins took the growthcritical ideas as point of departure for his program of "soft energy paths" that were to supersede the hitherto prevalent - and unsustainable "hard energy path". As a passionate opponent of nuclear power, Lovins ardently criticized the "hard path" conclusion that the political and energy establishment had drawn from the crisis. Instead of pushing nuclear power and readily available fossil fuels - especially coal - to secure fuel supplies, Lovins called for an end-use-orientation that would determine "how much of what kind of energy is needed to do the task for which the energy is desired, and then supplying exactly that kind." ${ }^{2}$ This reorientation from a source- and production-based toward an end-use based determination of energy needs was to work as a precondition for a direction change from the hard to the soft path of energy policy. The latter implied "a prompt and serious commitment to efficient use of energy, rapid development of renewable energy sources matched in scale and energy quality to end use needs, and special transition fossil fuel technologies." 53

Lovins' program attracted enormous attention. While the physicist Lovins did not elaborate the social consequences of his soft-path proposition,

1970s, see Samuel Hayes: Beauty, Health, and Permanence: Environmental Politics in the United States, 1955-1985. Cambridge: Cambridge University Press, 1987; Karl Ditt: “Ursprünge und Anfänge der Umweltpolitik in der Bundesrepublik während der 1960er und frühen 1970er Jahre”, in: Matthias Frese/Julia Paulus/ Karl Teppe, eds. Demokratisierung und gesellschaftlicher Aufbruch. Die 1960er Jahre als Wendezeit der Bundesrepublik. Paderborn: Ferdinand Schönigh, 2003, 305-47; Jens Ivo Engels: Naturpolitik in der Bundesrepublik. Ideenwelt und politische Verhaltensstile in Naturschutz und Umweltbewegung 1950-1980. Paderborn: Ferdinand Schöningh, 2006.

52 | Amory B. Lovins: Soft Energy Paths. Cambridge, MA: Friends of the Earth and Ballinger Publishing Co, 1977, 8.

53 | Lovins: Soft Energy Paths, 25. 
sociologists dealt with its implications for societal changes..$^{54}$ Thus, the soft-path-concept remained bound to the energy-civilization equation, as it expected to change society in fundamental ways by restructuring its energy provision and needs. While the energy establishment fiercely contested this vision, protagonists of the internationally strengthening environmental movement expanded it and developed new arguments for the urgency of the transition..$^{55}$ As early as 1981 , the challenge of climate change was introduced as an additional argument for the transition to soft energy paths. The urgency and international character of soft-path proponents are evident in the 1981 book Least-Cost Energy - Solving the $\mathrm{CO}_{2}$ Problem that Amory Lovins and his wife L. Hunter Lovins co-authored with their German colleagues Florentin Krause and Wilfrid Bach. ${ }^{56}$ Krause was a co-founder of the German Eco-Institute in Freiburg and a co-author of an energy study that was published under the title Energiewende (energy turn) in 1980. This study argued that economic growth would not require more energy and that especially nuclear energy should be abandoned and the use of fossil fuels could be significantly curtailed. ${ }^{77}$ Bach had headed the research center of applied climatology and environmental studies at the University of Münster since the mid-1970s and published widely on the relationship between energy use and climate change..$^{8}$

The no-growth scenario that was developed by alternative economists and the soft-path concept that stemmed from scientists fuelled the energy debate in the decade of the energy crisis and set the course for a rethinking of the energy-civilization equation. The anti-growth attitudes, however,

54 | Denton E. Morrison/Dora G. Lodwick: "The Social Impacts of Soft and Hard Energy Systems: The Lovins' Claims as a Social Science Challenge”, in: Annual Review of Energy 6 (1981), 357-78.

55 | Martin V. Melosi: Coping with Abundance.Energy and Environment in Industrial America. Philadelphia: Temple University Press, 1985, 316-19.

56 | Amory Lovins/L. Hunter Lovins/Florentin Krause/Wilfrid Bach: Least-Cost Energy - Solving the $\mathrm{CO}_{2}$-Problem. Andover, MA: Brickhouse Publication Co., 1981. 57 | Florentin Krause/Hartmut Bossel/Karl-Friedrich Müller-Reissmann: Energiewende. Wachstum und Wohlstand ohne Erdöl und Uran. Frankfurt/Main: Fischer, 1980.

58 | One of his early publications to this topic is Wilfrid Bach: "Impact of Increasing Atmospheric $\mathrm{CO}_{2}$ Concentration on Global Climate: Potential Consequences and Corrective Measures", in: Environment International 2 (1979), 215-28. 
got increasingly marginalised by a new consensus on ready-to-implement technical means for garnering more energy and using it more efficiently. Thus, for example, the Union of Concerned Scientists stated in its report on Energy Strategies: Toward a Solar Future:

"The United States can provide a high level of economic prosperity for all its citizens without the wastefully high levels of gross energy use characteristic of conventional government and industry projections. By increasing energy productivity and thereby deriving greater benefit from the energy we use, economic growth can be sustained with little or no growth in overall energy use." 59

The widespread consensus on the importance of a rise in energy efficiency put two very different groups of actors centre stage at the arena of energy policy. One were engineers serving as efficiency experts whereas the other group were consumers who were supposed to make the right choices about energy-consuming goods and services. In any case, the efficiency paradigm began to shift attention from the hitherto prevalent emphasis on energy production to energy use. ${ }^{60}$ In contrast to this emerging and still widely held consensus on energy efficiency as valuable conservation strategy ${ }^{61}$,

59 | Henry W. Kendall, Steven J. Nadis, eds.: Energy Strategies: Toward a Solar Future. A Report of the Union of Concerned Scientists. Cambridge, MA: Ballinger, 1980, 58.

60 | Despite broad acceptance, however, the efficiency paradigm was also met with scepticism as it was questioned with reference to rebound effects. On rebound effects refer to a growing body of literature, e.g. Sheetal Gavankar, Roland Geyer: The Rebound Effect: State of the Debate and Implications for Energy Efficiency Research. Bren School of Environmental Science and Management, University of California, Santa Barbara, 2010. http://iee.ucsb.edu/files/pdf/Rebound\%20Re port\%20for\%20IEE-UCSB_0.pdf, accessed 28.12.2011.

61 | Energy efficiency is the core element of the EU's Europe 2020 Strategy for smart, sustainable and inclusive growth and of the transition to a resource efficient economy. The European Union has set itself the target for 2020 of saving 20 percent of its primary energy consumption compared to projections. On the EU energy efficiency strategy cf. http://ec.europa.eu/energy/efficiency/index en.htm, Accessed 28.12.2011. 
attitudes on what sources of energy ought to be preferred differed widely. ${ }^{62}$ Here, the spectrum of proposed strategies reached from a substantial increase of nuclear power and a rapid return to coal to a strong preference for renewable energies, while suggestions for a proper energy mix with a rising percentage of natural gas stood as a middling position. ${ }^{63}$

The fact that the energy debate focussed ever more on energy transitions since the decade of the oil crisis caused social scientists and historians to revisit the energy-civilization equation. Since the early 1980s, the book market has offered an increasing array of publications dealing in one way or another with past and present energy societies. But while many books published prior to the energy crises of the 1970s had developed the energycivilization equation in terms of grand stage theories or clear evolutionary progress, post-energy-crises scholars provided more in-depth studies of specific energy systems and sources on the regional or the national level ${ }^{64}$, as well as detailed studies of various aspects of energy production and use. ${ }^{65}$ For the most part, however, these studies have been concerned with problems of

62 | Langdon Winner: "Energy Regimes and the Ideology of Efficiency", in: George H. Daniels, Mark H. Rose, eds. Energy and Transport. Historical Perspectives on Policy Issues. Beverly Hills: Sage, 1982, 261-77.

63 | More detailed is Vaclav Smil: Energy Transitions. History, Requirements, Prospects. Santa Barbara, CA: Praeger, 2010.

64 | Cf. among others the survey on the new German speaking electricity history by Bernhard Stier: “Die neue Elektrizitätsgeschichte zwischen kulturhistorischer Erweiterung und kommunikationspolitischer Instrumentalisierung", in: Vierteljahresschrift für Sozial- und Wirtschaftsgeschichte 87:4 (2000): 477-87.

65 | So far, only few scholars have aimed at exploring the societal and environmental implications of energy regimes from the perspective of global history. Cf. Vaclav Smil: Energy in World History. Boulder, C0: Westview Press, 1994; Smil: Energy at the Crossroads: Global Perspectives and Uncertainties. Cambridge, MA: MIT Press, 2003; Smil: Energy Transitions; Rolf Peter Sieferle: Rückblick auf die Natur. Eine Geschichte des Menschen und seiner Umwelt. München: Luchterhand, 1997; Rolf Peter Sieferle: Der unterirdische Wald: Energiekrise und Industrielle Revolution. München: Beck, 1982. For a recent, quite innovative but also debatable suggestion on using power as a synthesizing concept in history cf. Edmund Russell/James Allison/Thomas Finger/John K. Brown/Brian Balogh/W. Bernard Carlson: "The Nature of Power. Synthesizing the History of Technology and Environmental History”, in: Technology and Culture 52:2 (2011), 246-59. 
energy production, transition and provision while the (re)presentation and consumption of energy as well as the cultural perception of energy sources and its use has not yet found the attention it deserves. ${ }^{66}$ Approaching energy from the user and mediator perspective, however, is a promising way to get to a more detailed understanding of past and present energy societies and thus to avoid an uncritical replication of the energy-civilization premise that has been and partly still is quite influential in current energy discourses.

\section{Contributing Essays}

The aim of this anthology is to contribute to the current scholarly energy debate by shedding light on the political, technological and cultural premises of the high-energy society and its capacities of transitions. In Part One of this collection, the authors deal with cultural representations of energy and how these representations have shaped various high-energy societies of the $20^{\text {th }}$ century. Nina Möllers opens with an investigation of (re)presentations of energy at world's fairs from the late $19^{\text {th }}$ to the late $20^{\text {th }}$ century in the U.S. and Europe. As sites where host countries and cities, exhibitors, and visitors staged their dreams of how the world ought to be and how to get there with the help of new technologies, world's fairs provide excellent windows through which to view the historically changing meanings of electricity. Following designers and visitors through the exhibitions and tracing their communications via written and visual documentation, Nina Möllers shows how electricity was cast in a narrative of abundance that dominated the societal discourse on energy, in the U.S. and in Western Europe for most of the $20^{\text {th }}$ century. Only at the last fair examined - Knoxville, Tennessee, 1982 - was the narrative of abundance modified. Reworking through the preceding oil crises of the 1970 s, the fair staged a two-part drama. Scene One told the story of artificial scarcity as imposed by foreign hands, whereas Scene Two demonstrated that American ingenuity mastered the challenge and ensured a return to

66 | At the time still exceptional was David E. Nye: Consuming Power. A Social History of American Energies. Cambridge, MA: MIT Press, 1998. For a most recent user-centred energy history see Christopher Jones: "The Carbon-Consuming Home: Residential Markets and Energy Transitions", in: Enterprise and Society 12:4 (2011), 790-823. 
U.S. energy abundance and national security. In making the rich sources of energy display accessible via careful interpretation, Möllers discloses two related discourses - the promotional discourse of utility companies and consumer goods manufacturers and the societal discourse of energy abundance that was deeply engrained in all world's fairs displays no matter whether they dealt with energy explicitly or not. Both discourses worked together in shaping and communicating a careless energy consumption mentality that spread from the U.S. and became a role model for many societies. Whether they presented electricity as did the fairs in Chicago (1893 and 1933) and New York (1939) or atomic energy that was the big attraction in Brussels (1958) or renewable energies staged in Knoxville (1982), all world's expositions developed and perpetuated an energy narrative promising abundance. By exploring the efforts put into these constructions, Möllers shows that electricity is more than what flows out of wall sockets; it is energetic fluid of $20^{\text {th }}$ and $21^{\text {st }}$ century high-energy societies that must be produced, consumed, and understood on a material and a cultural level.

World's fairs were a prominent but by no means the only place for featuring cultural representations of electricity. At national, regional, and even local levels, utilities became most bustling actors in charging electricity with cultural meanings. Utilities managed to sell electricity only when they were able to convince consumers that it ensured a modern, superior lifestyle in contrast to old-fashioned cooking or heating with coal or gas. The volume's next two contributions take us to Germany and France, exploring how marketers of power companies designed electricity as an everyday life-enchanting icon of modernity.

Sophie Gerber delved deeply into the archives of Berlin's local electricity supplier Bewag, in order to disclose how the company charged electricity with meanings in their efforts to market electricity both before and after World War II. Because electricity is different from most other goods and services as it must be produced at the moment it is consumed, utilities recognized and sought to foster a tight bond between themselves and their customers. That bond was the electricity-consuming appliance. Therefore, utilities closely collaborated with the appliance industry in their marketing strategies. Bewag developed a broad variety of methods and means for advertising electricity. Not just through publications on electricity and appliances that appeared in newspapers, expert journals, customer magazines, and cookbooks and advertising; on buses, subways 
and in many other public spaces, but also via public advice centers, training kitchens, installment systems, and stove rental schemes. Utilities and their agents thereby sought to convey the message of progress and modernity through electricity. The narratives deployed throughout Bewag's marketing activities were closely connected to the immediate political context in (West) Germany. During the Weimar Republic, when people experienced hyperinflation and ongoing economic instability, Bewag constructed a narrative of the superiority of electricity through price and safety advantages. In the early years of the Nazi period, electric cooking became a new topic in the marketing efforts. Promoting kitchen ranges promised to increase the efficiency of the utility and at the same time it fit nicely into the Nazi images of 'Aryan' domesticity. With the advent of Germany's post-WWII economic 'miracle', increasing electricity sales became part and parcel of the new social contract based on mass consumption and promised to foster a German nation. Values such as modernity, freedom, leisure and progress provided subtexts within a broad array of electricity advertisements. These positive connotations of electricity, however, were challenged in the decade of the oil crises. Bewag adapted to the new situation as it developed fresh marketing methods in order to charge electricity with green - i.e. ecologically responsible - meanings. Bewag's marketing department developed a broadly accepted narrative on the meaning of electricity as is revealed in its steadily rising power sales, and thus, together with its tightly coupled customers, Bewag decisively contributed to the rapid development of the high-energy society and mentality that has proven to be so hard to reverse.

The third contribution in Part One is also concerned with the marketing strategies of an energy supplier, but this time in France. It covers more than half a century from the end of World War II until the turn to the $21^{\text {st }}$ century. Yves Bouvier has investigated promotional films produced on behalf of the French national electric company, Électricité de France (EDF). He aims to explore how these films worked as cultural representations of electricity and served the business strategy of the public company. The films stage - and therefore shape - the relationship between consumers and energy. Bouvier takes the French sociologists and semioticians Jean Baudrillard and Roland Barthes as points of departure as their approaches to deciphering the world of objects as myths and vehicles of meaning guide his analysis of his material. EDF's films represent energy in a narrative of abundance that developed in various, subsequent steps. In the mid- 
1950s, abundance was showcased as a system of electrical objects within the house that EDF had integrated into the modern world via its electricity. In the early 1960 s, after consumerism had become more important as the cement of the social order in France, abundance was featured as a rapid accumulation of appliances in households, which were supported by EDF via the installation of new meters. While the appliances in the 1950 s stood for concepts of comfort that implied a lessening of laborious housework, the message changed in the 1960 s. Now appliances became lifestyle objects and this imbued the narrative of abundance with an unmistakeable flavour of hedonism. The decade of the oil crises severely challenged the hitherto prevalent cultural representation of energy. The French response to the oil crises was twofold: The state extended and accelerated the transition to nuclear power and forbade energy advertising. Thus, EDF had to change the way it communicated with its consumers. It did so by producing films on how to save energy. In these films, not appliances but energysaving users with their consumption practices figured prominently. With these user projections, EDF was able to adhere to the original narrative of abundance, as the films advised the customers how to maintain an affluent lifestyle by saving energy. In the 1990s, finally, appliances reappeared in the promotional films, now more numerous than ever before. Hedonism had returned in a "hyper-consumer-society," and its architect was EDF. Thus, the cultural representations of energy in EDF's promotional films worked as important, constructed narratives for France's high-energy society; narratives that resonate with the marketing strategies of the German Bewag.

High-energy societies have not only been shaped by cultural representations of energy but also by actual consumption practices. Therefore, Part Two presents three case studies that deal with such energy consumption practices. Of course, energy is not consumed directly but through devices, materials, and processes - as warm water, artificial light, or a pleasantly warm room on a cold day. The authors of the three case studies explore, respectively, how the Bewag as an energy supplier, the German states in the era of the Cold War, and the Austrian social system cast consumption practices and thus contributed to the development of high-energy societies.

Nina Lorkowski probes consumers' warm water usage behind Berlin's bathroom and kitchen doors as a critical factor within Bewag's electricity supply strategy. Driven by the desire to improve the efficiency of power 
production by stimulating electricity demand during off-peak-hours, Bewag introduced a marketing and sales program for electric storage water heaters in the 1920s. These had been designed not just to increase the overall electricity demand but to store energy in the form of warm water because they used electric power for heating up water during off-peak hours during the night while their service, warm water, was to be used during the day and therefore without using power in peak-hours. The designers of Bewag's storage water heaters inscribed this usage pattern into the appliances via a time switch and an extra meter. Thus, Bewag controlled the heating-up period via the timer which the users could not manipulate. They could adjust the usage of the appliance to their own needs only by switching it off completely when the water heater was not needed over longer periods of time. This, however, contradicted the strategy of Bewag to use private households as energy storage for balancing load curves. With the economic downturn in the wake of the big crisis from 1929 to 1933, Bewag was confronted with an even larger problem. Because of the drastically decreasing industrial electricity demand, the company now sought to increase its power supply to households not only for balancing load curves but above all to utilize its power plant capacities through any and all possible means. Preventing users from switching off their water heaters and extending heating-up times during the day appeared as an appropriate strategy to increase households' electricity demand. For generating a more steady need for warm water, Bewag rented out water heaters with two or three outlets, one of which supplied the kitchen. The restrictions of charging time to night hours were abandoned. The consumption practice that Bewag had sought to inscribe in the appliance design, however, was adopted by consumers only partly, as they stuck to old hygiene and bathing customs with a weekly bathing day instead of showering daily. But once the appliance had found its way into the household, it at least opened the possibility for an increased residential energy use. This possibility began to materialize in the 1950s when the state's promotion of energy-consuming household appliances as part of the implementation strategy of the West German social market economy proved to be a tremendous success. Within this framework, however, the meaning of consumption and energy use changed according to consumers' growing expectations about convenience and hygiene. In this context, no longer could the utility company prescribe to the consumer which appliances should be used and how and when to guarantee a more balanced capacity utilization. Instead, surging residential 
energy demand now became a reason to generally extend power plant capacities. The case study by Lorkowski is revealing in two respects. It clearly shows how utilities conceived of households as elements of their production strategy and how they used appliances to shape consumer practices. But Lorkowski also points us to the actual consumers who rewrote the inscribed user scenario by using the appliances subversively. Thus, she makes us aware that imposed technical means for manipulating energy use are rather questionable strategies because energy consumption practices are the outcome of societal contracts and cultural traditions and not an unchangeably materialized script within technologies.

Not just appliances but also the organization of time has been mobilized to manipulate energy consumption practices. In the second case study, Matthias Mutz documents the introduction of Daylight Saving Time (DST) in order to understand its meaning within and beyond the energy discourse for both German states in the energy crises of the 1970s. The debate on DST began immediately in the wake of the first oil crisis in West Germany. Thus, DST was cast in the frame of an emergency measure, bearing resemblance to earlier DST introductions as wartime actions in the First and the Second World War. But the West German debates after the first oil shock (that had not hit East Germany because of oil contracts with the USSR) did not result in DST-introduction. In contrast to most European states that did advance their clocks for an hour in the mid-1970s, the political actors in Bonn and, with a time lag, the political players in East Berlin opted against changing clocks. Both governments used similar arguments as justifications. DST would provide only marginal energy savings, but it could, if not introduced in both German states at the same time, erect a time border and thus endanger the delicate balance in interGerman relations. The introduction of DST by European neighbour states was said to be a lifestyle choice and thus irrelevant for the two German states. Only after the second oil crisis did German attitudes change, and in October 1979, first in East Berlin and 13 days later in Bonn, the Germans decided to implement DST the following year. Mutz carefully outlines how energy policy contributed to this decision. In West Germany, DST increased the acceptance of energy saving that was now cast more in terms of energy efficiency and allowed everybody to participate in the saving 'hype' without changing individual consumption practices. In East Germany, DST worked as a substitute for an earnest energy policy with more effective energy saving measures. Energy consumption practices in private households 
remained untouched by the East German state, as it stuck to a constant low price for a kilowatt hour of electricity of 8 (nominal) Pfennig since 1946. In the end, both German states introduced DST not least because of its positive 'side effects' of leisure and recreation. Thus, DST contributed to the transformation of the energy discourse from a narrative of crisis and scarcity to a narrative of abundance and well-being, respectively. In this way, DST helped to maintain established energy consumption practices in the decades after the "golden years," as Hobsbawm described the 1950 s and 1960 s.

The last case study of Part Two takes us to contemporary Austria. Karl-Michael Brunner, Anja Christanell and Markus Spitzer investigate energy consumption practices in Austrian low-income households. While most studies on differences of energy consumption conceive of these inequalities in terms of their global dimension, this case study points to the fact that even within industrialised countries, residential energy consumption is far from being equally distributed throughout society. Analysing these differences, however, is crucial for governing the way toward a 'low-carbon-society,' as different lifestyles have different impacts on the environment while at the same time they vary in their vulnerability to climate change. The latter will have especially discriminative effects on low-income households as they have less means to make provisions for negative climate effects. Therefore, by exploring the phenomenon of fuelpoverty in the Austrian capital, Vienna, the authors shed light on the social dimension of energy consumption practices in order to address problems of environmental justice. As they look at housing and living conditions as well as heating and lighting practices, the contributors reveal how social inequalities become manifest in energy consumption practices. They show that fuel-poor households develop a specific energy culture via sacrifices in comfort and living standard. At the same time, low-income households encounter major difficulties in tapping their households' full efficiency potential due to factors beyond their reach, such as inefficient construction features of buildings, heating technologies, and larger, less efficient pre-installed household appliances in low-priced flats. Although fuel-poor households are forced to pioneer in energy saving strategies, they are disadvantaged in reaping the benefits. Therefore, the authors conclude, governing the transition to a socially just 'low-carbon society' requires societal interventions against fuel poverty. 
Part Three of this volume is concerned with cultural perceptions of and national discourses on energy resources. As the last and the ongoing centuries were and are marked by continual energy transitions due to various short-term emergency and longer-term structural forces such as imbalances in the world economy, wartime scarcity and global ecological policy, to name but a few, energy resources became a prominent subject of public debates. Three case studies trace these debates in Sweden, Norway and West Siberia in order to reveal what determined perceptions of both energy resources and the feasibility of energy transitions. The final chapter investigates the relationship between patterns of energy transitions and economic growth in Europe during the last two centuries.

Helena Ekerholm reconstructs the story of wood gas in Sweden, which was pursued as a national means of transitioning from petrol to domestic fuel alternatives between 1930 and 1945. But the planned fuel transition failed. Wood gas provides an interesting case in several respects: first, it is a renewable fuel; second, it played a partial role in the emerging automobile culture; third, it promised to boost the struggling forestry industry; and finally, wood gas was included in wartime emergency plans. Wood gasification technology was a $19^{\text {th }}$ century British invention that attracted interest as an alternative means of automobile propulsion in several countries across the globe early in the automobile era. Sweden began to consider wood gas as it looked for ways out of the crisis in the nationally important forestry industry in the early 1930s. By 1932, the Swedish government had established a wood gasifier loan fund intended to push the new technology, which experienced a fiasco after a short-lived boom. The gasifiers had not met user expectations for manifold reasons, which Ekerholm explores in detail. The loan failure resulted in new evaluations that established a more specific user profile. But not until the outbreak of World War II did wood gas receive a second chance, this time as a wartime surrogate. Optimists, however, expected an enduring breakthrough for wood gas and hoped that it would find its place in peacetime economy. But this did not come to pass for several reasons such as hazards connected to wood gas use and troublesome maintenance problems. These and other reasons contributed to the perception that wood gas usage was contradictory to the highly esteemed ideals of a modern automotive culture. Because wood gas could not overcome its connotations of wartime surrogate and outdated fuel, it did not endure. Thus, Ekerholm's story is a case study on a failed transition from fossil to renewable fuels. 
The next case study leads the readers to West Siberia and covers the four decades from the 1970 s to the present. In the decade when the oil crises hit the Western bloc, the Soviet state rapidly increased the exploitation of West Siberia's oil deposits. Since that time, the Soviet Union and then the Russian state has become increasingly dependent on the oil resources of this region, while in Western Europe efforts were taken to decrease carbon emissions from hydrocarbons by way of a transition to lower-carbon non-renewable and renewable sources of energy. By contrast, the rapid exploitation of the oil deposits in West Siberia not only prevented the Soviet and the Russian governments, respectively, from pondering an energy transition toward a more sustainable path, but it also caused tremendous environmental problems in West Siberia. Valentina Roxo analyses the public debates on West Siberian oil production in order to understand how, despite the coincidence of the West Siberian oil boom with the international boost of environmentalism, the latter did not have any impact on the former. Roxo shows that until the mid-1980 environmental data had been kept secret in the USSR and no public discussion could emerge. Only as a result of the glasnost reforms and especially following the Chernobyl catastrophe did environmental institutions spring up, decrees were issued, and ecological problems began to be discussed openly. But the most critical problems in the oil sector were left out of the public debate. Instead, in the wake of the Chernobyl disaster, oil was perceived as a secure source to meet the energy needs. This positive attitude toward oil took the form of a socialist version of a Promethean discourse, as the conquest of nature for the extraction of oil was celebrated as a human achievement. The depletion of natural resources and environmental destruction from oil extraction was denied by Soviet leaders. The finiteness of resources was to be overcome by science and technology and communism would lead to a state of abundance. Also, the narrative of the development of the West Siberian region from a backward place into a modern industrial landscape was cast as Promethean discourse. That living conditions of the indigenous West Siberian people had changed completely was glorified as tremendous progress. Only when the Soviet Union collapsed, did a more critical discourse begin to emerge. The lot of the indigenous population, conflicts between them and the oil industry, the poor state of the new cities in the region, and the environmentally disastrous practice of gas flaring - all these problems now came to the fore. But after the turn of the new millennia, the just-emerging environmental discourse began to be superseded again, this time by the 
debates on dangerous symptoms of the so-called Dutch disease. Now economic debate drew all attention, and the ecological tragedy of Samotlar, which the World Bank had declared an ecological disaster zone in 2000 , disappeared into oblivion, at least in the Russian media. Roxo ends her discourse analysis with the conclusion that the vital importance of the oil wealth for the national economy led to a dramatic ecological blindness of both state energy policy and the energy consuming Russian people.

Contradictory perceptions of energy resources were by no means confined to fossil fuels. The next contribution introduces readers to ambivalent public attitudes toward bioenergy in today's Norway and Sweden. These ambivalent opinions exist at various levels. The case study focuses on views that have been ascribed to imagined publics by policy makers, experts and the bioenergy industry, as these protagonists of bioenergy interpret what they assume are public perceptions of bioenergy. According to insights from Science and Technology Studies, the success of controversial innovations hinges upon public engagement in science and technology. Thus, the protagonists of bioenergy innovations have to imagine their publics and engage them in their projects. Tomas Skjølsvold probes how the bioenergy players imagine their publics in Norway and in Sweden and how these imagined collectives determine the strategies of public engagement. Bioenergy occupies very different places in the respective energy regimes of Norway and Sweden. In Norway, where it gained political attention as a potential replacement for space heating based on hydroelectricity, bioenergy is a niche technology. In contrast, Sweden has a more diverse energy regime based on three nearly equally important energy sources: fossil fuels, hydroelectricity and nuclear power. Both to reduce their dependence on fossil fuels and nuclear power and to mitigate climate change, the Swedes developed an early interest in bioenergy and advanced its contribution to total energy supply to one third. Therefore, in Sweden, bioenergy is at the core of energy policy, and it has become the largest energy-producing technology within the Swedish energy regime. Skjølsvold takes this significant difference between the two countries as point of departure to analyse how each nation's bioenergy establishment construe its imagined publics. He demonstrates how this difference remarkably influenced the ideas about bioenergy's respective publics. These ideas have been much more unfavourable in Norway than in Sweden. Norwegians are thought to be opposed to the construction of new bioenergy facilities because of landscape alterations, pollution, odors 
and increased traffic. The Swedes, however, are construed as passive but positively-minded consumers who would not care about bioenergy production, as they take it for granted. To be sure, the ideas about the public have many more facets in both countries, as Skjølsvold clearly shows. But the significant difference between imagined more sceptical Norwegian and more affirmative Swedish publics remains visible even in the many-facetted picture. Accordingly, the bioenergy players draw different conclusions for their subsequent strategies to engage their publics. While the Swedes seek to enlighten the imagined passive consumers and to develop an open, two-way dialogue, the Norwegians opt for meetings with perceived stakeholders prior to the construction of new facilities in order to prevent protests. Through his comparative analysis, Skjølsvold shows how even imagined, culturally-constructed agents play important roles in shaping energy transitions.

The final contribution in this anthology is concerned with the connection between energy and long-term economic growth in Europe. In her first part, Silvana Bartoletto analyses the debate whether there was an energy crisis in the $18^{\text {th }}$ century that caused the transition from traditional to modern energy sources in the $19^{\text {th }}$ century. Although the question has remained unsettled so far, there is no doubt about the multiple ways and chronological differences the energy transition took across Europe. The passage from the old to the modern energy system occurred rapidly in countries like England and Wales and to some degree in the Netherlands, while in Sweden, Italy and Spain, the transition followed only in the $20^{\text {th }}$ century. In her second part, Bartoletto outlines the results of the transition as they are manifested in the structure of the fossil fuel system and the distribution of energy consumption by sector. She notes the gradual turning away from oil after the crises in the 1970s and gives evidence for industry, transport and the residential sectors as the main energy consumers in Europe in 2007. Changes in the intra- and inter-sectorial distribution of energy consumption cause important variations of energy demand due to structurally different energy intensities. Bartoletto uses the long-term development of energy intensity, i.e. the energy required to produce one unit of output, as an indicator to gauge the relationship between energy, economy and technological change. After a detailed discussion of a broad array of determining factors for energy intensities and their changes, Bartoletto concludes that this indicator alone is not sufficient to fully understand the relation between energy, economy and 
technological change. Therefore, she introduces energy productivity as the reciprocal of energy intensity, i.e. the income produced per unit of energy. This allows her to draw a more detailed picture with the help of a decomposition analysis of per capita GDP, which enables her to determine the contribution of the growth rate of energy consumption per capita and the growth rate of energy productivity to the growth rate of per capita GDP. Her data reveal four distinct periods, each characterised by a specific energy-growth relationship. The first period, from 1830 to the end of the $19^{\text {th }}$ century, shows a reduction of energy productivity. In the next phase, from the beginning of the $20^{\text {th }}$ century until World War II, the productivity of energy became more important for economic growth, especially because of improvements in the efficiency of techniques of energy utilization. From the end of the Second World War until the energy crises of the 1970s, readily available cheap energy was more important for economic growth than any gains in thermodynamic efficiency of the techniques in question. After the decade of the oil crises, finally, improvements in energy efficiency became more and more important in economic growth. As Bartoletto reveals these long-term trends in the relation between energy, economy and technological change for the European context, she raises our awareness of the long-running nature and complexities of energy transitions. Thus, we may better understand what the current - and increasingly urgent - energy transition to a more sustainable regime will entail.

\section{BibLIOGRAPHY}

Adams, Henry. The Education of Henry Adams. Boston: Houghton Mifflin, 1961.

Akin, William E. Technocracy and the American Dream: The Technocrat Movement, 1900-1941. Berkeley: University of California Press, 1977.

Bach, Wilfrid. "Impact of Increasing Atmospheric $\mathrm{CO}_{2}$ Concentrations on Global Climate: Potential Consequences and Corrective Measures", in: Environment International 2:4-6 (1979): 215-28.

Basalla, George. "Energy and Civilization", in: Chauncey Starr/Philip C. Ritterbush, eds. Science, Technology, and the Human Prospect: Proceedings of the Edison Centennial Symposium. New York: Pergamon Press, 1980, 39-52.

Bebel, August. Die Frau und der Sozialismus. $37^{\text {th }}$ ed. Stuttgart: Dietz, 1904. 
Bell, Daniel. The End of Ideology: On the Exhaustion of Political Ideas in the Fifties. Glencoe, IL: Free Press, 1960.

Carey, James W./Quirck, John J. “The Mythos of the Electronic Revolution”, in: The American Scholar 39 (1970): 219-41, 395-424.

Coopersmith, Jonathan. The Electrification of Russia, 1880-1926. Ithaca, NY: Cornell University Press, 1992.

Cottrell, Frederick W. Energy and Society: The Relation between Energy, Social Changes, and Economic Development. New York: McGraw-Hill, 1955.

Daly, Herman E. Steady-State Economics. San Francisco: Freeman, 1977.

Diesel, Rudolf. Diesel's Rational Heat Motor: A Lecture. New York: Progressive Age, 1897 .

Ditt, Karl. "Ursprünge und Anfänge der Umweltpolitik in der Bundesrepublik während der $1960 e r$ und frühen 1970er Jahre”, in: Matthias Frese/Julia Paulus/Karl Teppe, eds. Demokratisierung und gesellschaftlicher Aufbruch. Die 196oer Jahre als Wendezeit der Bundesrepublik. Paderborn: Ferdinand Schönigh, 2003, 305-47.

Doel, Ronald. The Handbook of Texas Online. "Hubbert, Marion King". http://www.tshaonline.org/handbook/online/articles/fhu85, Accessed: 15.12.2011.

Elsner, Henry. The Technocrats: Prophets of Automation. Syracuse, NY: Syracuse University Press, 1967.

Engels, Jens Ivo. Naturpolitik in der Bundesrepublik. Ideenwelt und politische Verhaltensstile in Naturschutz und Umweltbewegung, 1950-1980. Paderborn: Ferdinand Schöningh, 2006.

Feynman, Richard P./Leighton, Robert B./Sands, Matthew. Feynman Lectures on Physics: Mainly Mechanics, Radiation, and Heat. 3 vols. Reading, MA: Addison-Wesley, 1966.

Gavankar, Sheetal/Geyer, Roland. "The Rebound Effect: State of the Debate and Implications for Energy Efficiency Research”. Bren School of Environmental Science and Management, University of California, Santa Barbara, 2010. http://iee.ucsb.edu/files/pdf/Rebound\%2oReport\%20 for\%2oIEE-UCSB_o.pdf, Accessed 28.12.2011.

Geddes, Patrick. "Civics: As Concrete and Applied Sociology, Part II", in: Sociological Papers 2 (1906), 58-119, available at http://www.gutenberg. org/files/13205/13205-h/13205-h.htm, Accessed: 28.12.2011.

-. Cities in Evolution: An Introduction to the Town Planning Movement and the Study of Civics. London: Williams \& Norgate, 1915. 
Georgescu-Roegen, Nicholas. The Entropy Law and Economic Process. Cambridge, MA: Harvard University Press, 1971.

Hayes, Samuel. Beauty, Health, and Permanence: Environmental Politics in the United States, 1955-1985. Cambridge: Cambridge University Press, 1987.

Hellige, Hans Dieter. "Wirtschafts-, Energie- und Stoffkreisläufe in säkularer Perspektive: Von der thermodynamischen Entzauberung der Welt zur recyclingorientierten Wachstumsgesellschaft”, in: Gangolf Hübinger/Ernst Schulin, eds. Universalgeschichte und Nationalgeschichten. Freiburg im Breisgau: Rombach, 1994, 291-315.

Hohensee, Jens. Der erste Ölpreisschock 1973/74. Stuttgart: Steiner 1996.

Hughes, Thomas P. American Genesis: A Century of Invention and Technological Enthusiasm, 1870-1970. New York: Viking, 1989.

Huxley, Aldous. "Progress" in: Vanity Fair 29 (1928): 69-76.

Jones, Christopher. “The Carbon-Consuming Home: Residential Markets and Energy Transitions", in: Enterprise and Society 12:4 (2011), 790-823.

Kendall, Henry W./Nadis, Steven J., eds. Energy Strategies: Toward a Solar Future - A Report of the UCS. $2^{\text {nd }}$ ed. Cambridge, MA: Ballinger, 1980.

Krause, Florentin/Bossel, Hartmut/Müller-Reissmann, Karl-Friedrich. Energie-Wende. Wachstum und Wohlstand ohne Erdöl und Uran. Frankfurt/ Main: Fischer, 1980.

Layton, Edwin T. The Revolt of the Engineers: Social Responsibility and the American Engineering Profession. Cleveland, OH: Case Western Reserve University Press, 1971.

Lindsay, R. Bruce. Energy. Historical Development of the Concept. Stroudsburg, PA: Dowden, Hutchinson \& Ross, 1975.

Lovins, Amory B. Soft Energy Paths. London: Penguin, 1977.

—. /Lovins, Hunter/Krause, Florentin/Bach, Wilfrid. Least-Cost Energy Solving the $\mathrm{CO}_{2}$-Problem. Andover, MA: Brickhouse, 1981.

Maier, Charles S. "Zwischen Taylorismus und Technokratie: Gesellschaftspolitik im Zeichen industrieller Rationalität in den zwanziger Jahren in Europa”, in: Michael Stürmer, ed. Die Weimarer Republik. Belagerte Civitas. Königstein: Athenäum, 1985, 188-213.

Marx, Karl. Capital. A Critique of Political Economy, Volume One. http:// www.marxists.org/archive/marx/works/1867-c1/index.htm, Accessed 28.12.2011.

- The Poverty of Philosophy. http://www.marxists.org/archive/marx/ works/1847/poverty-philosophy/cho2.htm, Accessed 28.12.2011. 
Mayumi, Kozo. The Origins of Ecological Economics: The Bioeconomics of Georgescu-Roegen. London: Routledge, 2001.

McKinnon, Andrew M. “Energy and Society: Herbert Spencer's 'Energetic Sociology' of Social Evolution and Beyond”, in: Journal of Classical Sociology 10:4 (2010), 439-55.

Melosi, Martin V. Coping with Abundance. Energy and Environment in Industrial America. Philadelphia: Temple University Press, 1985.

Merrill, Karen R. The Oil Crisis of 1973-1974: A Brief History with Documents. Boston: Bedford/St. Martin's, 2007.

Morrison, Denton E./Lodwick, Dora G. “The Social Impacts of Soft and Hard Energy Systems: The Lovins' Claims as a Social Science Challenge", in: Annual Review of Energy 6:1 (1981): 357-78.

Mumford, Lewis. Technics and Civilization. New York: Harcourt, 1934.

Nye, David E. Electrifying America: Social Meanings of a New Technology, 1880-1940. Cambridge, MA: MIT Press, 1997.

-. Consuming Power. A Social History of American Energies. Cambridge, MA: MIT Press, 1998.

- When the Lights Went Out. A History of Blackouts in America. Cambridge, MA: MIT Press, 2010.

Ostwald, Wilhelm. Energetische Grundlagen der Kulturwissenschaft. Leipzig: Klinkhardt, 1909.

—. Der energetische Imperativ. Leipzig: Akad. Verl. Ges., 1912.

Pursell, Carroll. "Domesticating Modernity: The Electrical Association for Women, 1924-86", in: The British Journal for the History of Science 32:1 (1999): 47-67.

Rifkin, Jeremy. Entropy. A New World View. New York: The Viking Press, 1980.

- The Third Industrial Revolution: How Lateral Power is Transforming Energy, the Economy, and the World. London: Palgrave Macmillan, 2011.

Russell, Edmund/Allison, James/Finger, Thomas/Brown, John K./Balogh, Brian/Carlson, Bernard W. "The Nature of Power. Synthesizing the History of Technology and Environmental History”, in: Technology and Culture 52:2 (2011), 246-59.

Sahlins, Marshall D. "Energy and Society: The Relation between Energy, Social Change, and Economic Development. W. Frederick Cottrell”, in: American Anthropologist 58:6 (1956): 1141-44.

Schenk, Julius. Die Begriffe Wirtschaft und Technik und ihre Bedeutung für die Ingenieurausbildung. Breslau: Preuss \& Jünger, 1913. 
Scott, Howard. “The Hotel Pierre Address." New York City. 13.01.1933, http://www.technocracy.org/technical-alliancetn/howard-scott/208societyscott, Accessed: 15.12.2011.

Segal, Howard P. Recasting the Machine Age: Henry Ford's Village Industries. Amherst, MA: University of Massachusetts Press, 2005.

Sieferle, Rolf Peter. Rückblick auf die Natur. Eine Geschichte des Menschen und seiner Umwelt. München: Luchterhand, 1997.

-. Der unterirdische Wald: Energiekrise und Industrielle Revolution. München: Beck, 1982.

Smil, Vaclav. Energy Transitions: History, Requirements, Prospects. Santa Barbara, CA: Praeger, 2010.

-. Energy at the Crossroads: Global Perspectives and Uncertainties. Cambridge, MA: MIT Press, 2003.

—. Energy in World History. Boulder, CO: Westview Press, 1994.

Soddy, Frederick. Matter and Energy. London: Williams and Norgate, 1912.

-. Science and Life. New York: E. P. Dutton, 1920.

-. Wealth, Virtual Wealth and Debt: The Solution of the Economic Paradox. London: Allen \& Unwin, 1926.

Spencer, Herbert. First Principles. New York: A. L. Burt, 1880.

Stier, Bernhard. "Die neue Elektrizitätsgeschichte zwischen kulturhistorischer Erweiterung und kommunikationspolitischer Instrumentalisierung”, in: Vierteljahresschrift für Sozial- und Wirtschaftsgeschichte 87:4 (2000): 477-87.

Veblen, Thorstein. The Engineers and the Price System. Kitchener, ON: Batoche Books, 2001 [1921], available at http://socserv.mcmaster.ca/econ/ ugcm/31l3/veblen/Engineers.pdf, Accessed 28.12.2011.

Weber, Max. "Energetische Kulturtheorien”, in: Gesammelte Aufsätze zur Wissenschaftslehre. Tübingen: Mohr, 1968, 400-26.

Wengenroth, Ulrich. "Motoren für den Kleinbetrieb: Soziale Utopien, technische Entwicklung und Absatzstrategien des Kleingewerbes im Kaiserreich”, in: Ulrich Wengenroth, ed. Prekäre Selbständigkeit: Zur Standortbestimmung von Handwerk, Hausindustrie und Kleingewerbe im Industrialisierungsprozess. Stuttgart: F. Steiner, 1989, 177-205.

White, Leslie A. "Energy and the Evolution of Culture", in: American Anthropologist 45:3 (1943): 335-56.

-. The Evolution of Culture: The Development of Civilization to the Fall of Rome. New York: McGraw-Hill, 1959. 
Willeke, Stefan. Die Technokratiebewegung in Nordamerika und Deutschland zwischen den Weltkriegen. Frankfurt/Main: Lang, 1995.

Winner, Langdon. "Energy Regimes and the Ideology of Efficiency", in: George H. Daniels/Mark H. Rose, eds. Energy and Transport: Historical Perspectives on Policy Issues. Beverly Hills, CA: Sage, 1982, 261-77.

Zachmann, Karin. "Wirkungsgrad contra Wertgrad: Zur Entstehung des Konflikts zwischen der technischen und der ökonomischen Auffassung vom Wirtschaften", in: Technikgeschichte 62:2 (1995): 103-31.

- Mobilisierung der Frauen. Technik, Geschlecht und Kalter Krieg in der DDR. Frankfurt/Main: Campus, 2004. 

Cultural Representations of Energy 



\section{Electrifying the World}

\section{Representations of Energy and Modern Life at World's}

Fairs, 1893-1982

\section{NINA MÖLLERS}

"Sell the cook stove if necessary and come. You must see the fair." With these words, novelist Hamlin Garland urged his parents to visit the World's Columbian Exposition in Chicago in 1893. Since their inception, contemporaries and academic scholars alike have been fascinated by what world's fairs have had to offer: from spectacular architecture to technological 'firsts' to - from a postcolonial perspective rather disconcertingly called - 'midget' and 'savage' African villages. Exhibitions in general and the hugely popular world's fairs in particular function as mediators between the political, economic and social actors involved in exhibition-making and the public. Their exhibitionary scenarios convey ideas - realistic or utopian - on how we live, work and play. World's fairs' ingrained perspective toward future life models coincided perfectly with the role that energy particularly electrical energy - was assigned to play in the $20^{\text {th }}$ century. Similar to other media, world's expositions offered interpretations of (future) energy production and use that were closely linked to discourses on modernity and progress. In contrast to print, radio and film, however, their displays visually created arrangements that could be explicatory, suggestive or illusionistic by means of their three-dimensional use of text, image, object and space. ${ }^{2}$

1 Q Qtd. in Justus D. Doenecke: "Myths, Machines and Markets: The Columbian Exposition of 1893", in: Journal of Popular Culture 6:3 (1973), 535.

2 | Gottfried Korff: "Scheinkapellen u. ä. Sieben Bemerkungen zu den diskursiven und visuellen Strategien des Geschichtsmuseums im Jahrhundert seiner Eta- 
Moreover, world's expositions' treatment of technology was often characterized by a focus on the present, even the future. Serving as a "site within the transitory present from which the visitor could glimpse the future", world's fairs took advantage of what David Nye has called the technological sublime. ${ }^{3}$ According to him, a number of interrelated sublimes had emerged in America since the 1820 s, i.e. the geometrical, the industrial and the electrical sublime, each of them having a distinct political and social relation to technology. Americans reinvested "the landscape and the works of men with transcendent significance" 4 and developed a reasoning that saw inventions and new technological structures as continuations of nature, ultimately raising them to the status of "selfjustifying parts of a national destiny." 5 This blending of the natural and the technological sublime was supplemented by a third kind of experience the "electrical sublime" - eliminating the distinction between natural and artificial sites. ${ }^{6}$

As Nye has aptly shown, world's fairs were ideal sites for the materialized display of the technological sublime in general and the electrical sublime in particular. On their exhibition floors, ideas of energy technologies as the sublime merged with modernist discourses to create narrations of the future built on inexhaustible energy resources and carefree consumption. However, because of its dual nature as "both a commodity and a fundamental aspect of being"7, energy and its narratives are at times difficult to disentangle from larger political, scientific and cultural discourses. This paper therefore offers a close reading of energy (re-)presentations in world's fairs both as symbol for a progressive, modern lifestyle and as a consumer good from the late $19^{\text {th }}$ to the late $20^{\text {th }}$ century. Based on both visual and written documentation, it examines selected displays of the fairs of Chicago 1893 and 1933, New York 1939, Brussels 1958

blierung”, in: Bernhard Graf/Hanno Möbius, eds. Zur Geschichte der Museen im 19. Jahrhundert; 1789-1918. Berlin: G + H Verlag, 2006, 117.

3 | David Nye: American Technological Sublime. Cambridge, MA: MIT Press, 1996, 205.

4 | Nye: American Technological Sublime, xiii.

5 | Nye: American Technological Sublime, 282.

6 | Nye: American Technological Sublime, 152.

7 | David E. Nye: Narratives and Spaces. New York: Columbia University Press, 1997, 75. 
and Knoxville 1982 as they relate to discourses on science and industry, nature, mass consumption and modernity. As pacemakers and role models, these American fairs played a decisive part in shaping the development of an energy-intensive lifestyle and consumption mode enabled by an implied and largely unquestioned narrative of energy abundance. Both national and corporate displays at these fairs served as reference points and models regarding visions of modern living and consumption as well as exhibition design and mediation that would be imitated in other parts of the world.

Understanding exhibits as a particular form of communication, it makes sense to analyze the displays within the framework of larger political and social energy narratives which, according to David Nye, have historically focused on either one of these five contextual preconceptions: 1) natural abundance, 2) artificial scarcity, 3) human ingenuity, 4) manmade apocalypse and 5) existential limits. ${ }^{8}$ Although each of them has gained currency at some point in history, it is the narrative of abundance that dominates the way how energy is constructed, interpreted and cast in the media discourse in the United States for most of the $20^{\text {th }}$ century. As shall be argued in this paper, it is also the narrative that comes to bear on the presentations of energy at the fairs in 1893 and the 1930 s and to some extent the Brussels fair of 1958 . Here, however, with the introduction of nuclear power, the narrative of abundance merged with the narrative of human ingenuity ensuring affluence by applying refined engineering skills. The final fair - Knoxville 1982 - represents an interesting mixture of narratives. While showcasing elements both of the artificial scarcity and the man-made apocalypse narratives, it simultaneously marks the return to the natural abundance narrative.

No matter which energy narrative dominates, it is always mediated through exhibitionary means. These include, first and foremost, threedimensional objects displayed in the exhibition space, supplemented by texts, images, lighting arrangements and other media. Over the course of the fairs' history, the exhibitionary modes have changed dramatically, influencing not just the 'vocabulary' used to convey its messages, but rather the content of the narrative itself. In many respects twins of the concurrently emerging department stores and shopping malls, the fairs served as mediators for America's budding consumer society where people learned to view energy, especially electricity, as the doorway to a new quality

8 | Nye: Narratives and Spaces, 77. 
of life. Modifying traditional museum display modes, the fairs created a new presentational vocabulary that could be read by a 'republic of consumers' within the codes of modern industrial culture. The more industrialized a nation and its culture became, the more symbolism was attached to technological and industrially manufactured goods, their representation in advertising, department stores and exhibitions and their consumption by the people. In the display context of world's fairs, these goods became a defining part of a "rationalized mythology" in which the displayed object oscillated between the profane and the auratic. ${ }^{9}$ It was at Chicago's White City in 1893 where this oscillation between sublime wonder and profane application found its supreme expression.

\section{World's Columbian Exposition, Chicago 1893}

In terms of its usage of electricity, Chicago's first world fair would become known for both its elaborate lighting designs on the fairgrounds as well as its Electricity Pavilion prominently situated at the center of the fairgrounds.

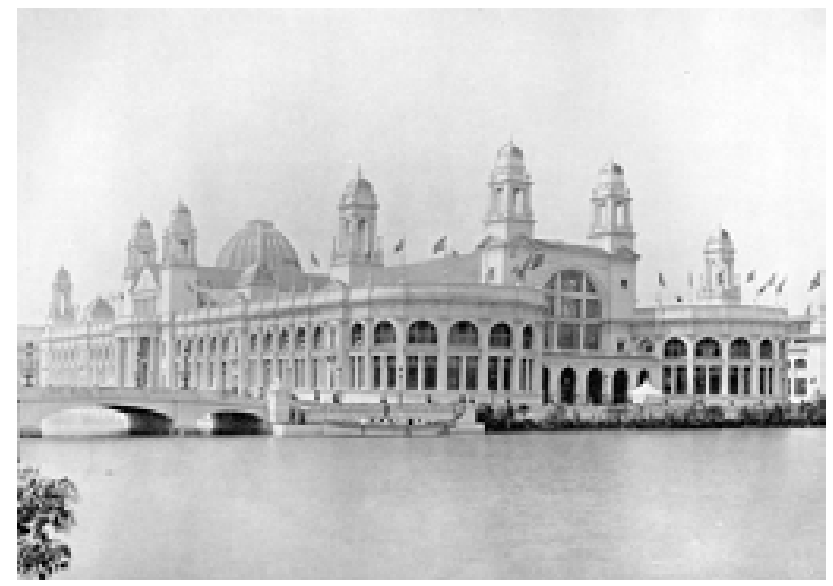

Figure 1: Electricity Building, World's Columbian Exposition, Chicago 1893.

9 | Elke Krasny: “Zukunft ohne Ende: Das Unternehmen Weltausstellung”, in: Brigitte Felderer, ed. Wunschmaschine Welterfindung. Wien: Springer, 1996, 322. 
Its architecture was meant to correspond with both the qualitative nature of electricity and the contents shown inside, giving "to the general design a movement which, in contrast with its neighbors, may be suggestive of the mysterious functions of electricity." 10 In accordance with the fashion and level of electrotechnology at that time, the fairgrounds presented themselves as an 'electrified landscape' including electrically-powered water fountains, enormous searchlights, an electric walkway and batteryrun boats on the basin. ${ }^{11}$ What presented itself to the visitors as a technical triumph "harnessing the thunderbolts at last"12 had actually been preceded by a furious battle between Thomas Edison's General Electric Company and its rival Westinghouse. Due to a lower bid and apparently a stronger argument for reliable capacity, it was Westinghouse that ultimately got the job of illuminating the fair, thereby delivering the final deathblow to Edison's direct current system. ${ }^{13}$ Yet, despite rapid innovations in the field of electric technology, many Americans remained skeptical about the reliability and safety of electric applications in their homes. The Chicago fair offered a prime opportunity for corporations involved in the electrification business to showcase electricity's advantages and eradicate any persisting doubts.

The inside of the pavilion contributed to that particular effort only to a limited extent. Firmly anchored in the systemic approach, the individual displays featured electrotechnical 'hardware' ranging from apparatuses illustrating the phenomena and laws of electricity to batteries, transmission gear and electro-chemical equipment. ${ }^{14}$ Most impressive among the

10 | Rand, McNally \& Cos.: A Week at the Fair Illustrating the Exhibits and Wonders of the World's Columbian Exposition. Chicago: Rand, McNally \& Cos., 1892, $80,82$.

11 For a discussion of outside electric lighting at world's fairs see David E. Nye: “Electrifying Expositions, 1880-1939”, in: Robert W. Rydell/Nancy Gwinn, eds. Fair Representations. World's Fairs and the Modern World. Amsterdam: VU University Press, 1994, 140-56.

12 | Murat Halstead: "Electricity at the Fair", in: The Cosmopolitan. An Illustrated Monthly Magazine 15:5 (September 1893), 578.

13 | Judith A. Adams: "The Promotion of New Technology through Fun and Spectacle: Electricity at the World's Columbian Exposition", in: Journal of American Culture 18:2 (1995), 49.

14 | Rand: A Week at the Fair, 83. Although the Austrian inventor and entrepreneur Friedrich Wilhelm Schindler presented the first electrical kitchen at the fair 
"monster machines"15 was the generating station supplying all buildings at the fairground with electricity. The imposing machinery and sheer endless rows of electrical equipment tended to make engineering experts and technology buffs go ecstatic but the general public rather less so. Apparently, however, this had not been the exhibitors' intention anyhow. The order in which the chief of the electricity department enumerated the target groups of his pavilion is by no means accidental: engineers, central station managers, manufacturers, students and - finally - the public in general. ${ }^{16}$

Hence, the fair of 1893 proved to be transitional in its representation of electricity, exposing a two-lane display strategy separating the inside from the outside: While technical aspects of its production and distribution dominated the interior of the building, 27 million visitors strolling the fairgrounds outside got a foretaste of the consumption paradise to come by using the electrical railway and walkway and experiencing the nightly lightshow. Yet, powered by a large electrical system, lighting and railways appeared to be moved by a magical hand and related the qualities of the new energy form only indirectly to people. Although small electrical consumer appliances for mass consumption already loomed on the horizon, the Columbian fair focused on the communal experience of electricity as symbol for modernity. The electrical transportation and lighting systems thus retained a sublime touch: Using the moveable sidewalk and watching the buildings being bathed in artificial light disrupted people's ordinary perceptions of their surroundings and forced them to grapple with its immensity and power. ${ }^{17}$ However, searching for new opportunities of application and sales markets, manufacturers and utilities wanted people to eventually overcome their awe and start treating, i.e. consuming, electricity unreservedly. The immateriality of electricity posed a serious problem to this endeavor. In what comes across as a clumsy attempt at making people 'see' and 'feel' electricity, exhibition designers came up with

gaining him a gold medal, it was not named in any of the original sources surveyed for this paper.

15 | J. R. Cravath: “Electricity at the World's Fair”, in: Review of Reviews (July 1893), 38.

16 | Hubert Howe Bancroft: The Book of the Fair. Chicago: Bancroft, 1893, 405.

17 | Nye: American Technological Sublime, 15. 
rather bizarre object arrangements such as pyramids of copper wires and towers of insulators.

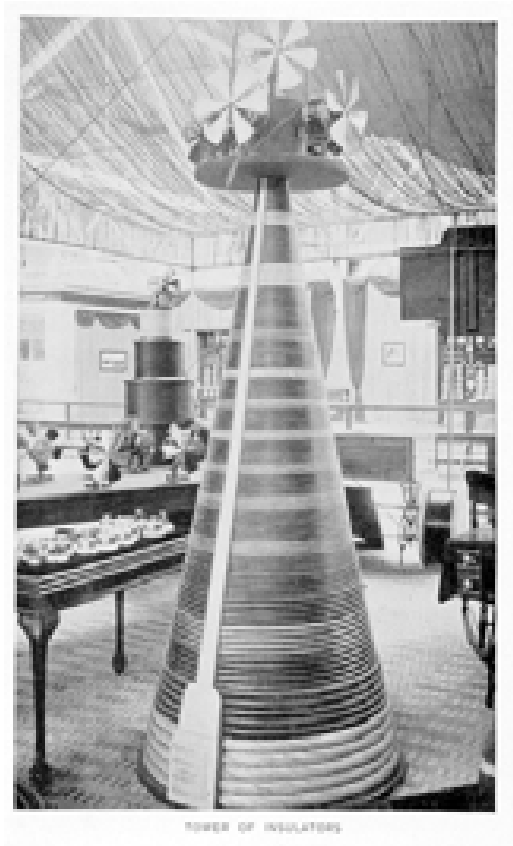

Figure 2: Tower of Insulators, Electricity Building,

Columbian World's Exposition, Chicago 1893.

Electricity's intangibility confronted exhibition designers with problems that became symptomatic for the world's fairs to follow. Even with the outside lighting spectacle that allowed for sublime sensations, the apparently mysterious nature of electricity needed earthing. The ceremonial opening of the fair provided this by means of a surrogate tactile action performed by President Grover Cleveland. With the president pushing a gilded button on a stand draped with the Star-Spangled-Banner, a connection was made between man and his actions and the miracle of electrical lighting. From one moment to the next, the rumble of machines was heard, water gushed from the fountains, banners and flags were unfurled and the massive Statue of Freedom was unveiled. The immateriality of electrical energy that proved to be both fascinating and threatening to people was packaged into symbolic acts of starting engines and pushing buttons. 
In Chicago at the end of the $19^{\text {th }}$ century, the energy narrative of abundance had yet to materialize. Setting the stage for a multitude of applications in transport, industry and at home, the fair hinted at the great utopia of infinite energy used for the building of a better world without quite formulating it yet. It rather allowed people from all walks of life to "gaze into the future and ponder upon the marvellous uses of electricity which must be in store for us at no very distant date." 18

\section{A Century of Progress Exposition, ChICAgo 1933-1934 ${ }^{19}$}

About thirty years after the Columbian Exposition, three-fourths of private households in the United States had been electrified ${ }^{20}$, urban centers were growing, more and more cars traveled across the expanding highway system and mass-consumption was in full swing. Yet with the crash of 1929, America had also sunk into a deep economic depression which left many in doubt about the merits of modern consumer capitalism. Although electricity had brought unknown comforts, Americans at the same time feared for their personal economic and social future. While utility companies and appliance manufacturers proceeded with building an infrastructure of high-energy consumption technology, cultural and social mediation was needed to keep people abreast with the fast developing and changing technical world around them. Alongside national advertising campaigns and mediating councils such as the Society for Electrical Development, exhibitions served as promoters of the modern 'electrical way'.

In the ambivalent mood oscillating between hope for a bright future and lingering fears about its fragility, the organizers of the second Chicago fair in 1933 conceptualized their exhibitions around the intricate relationship between science and industry to "demonstrate to an International [sic]

18 | John Brisben Walker: "A World's Fair. Introductory: A World's College of Democracy", in: The Cosmopolitan. An Illustrated Monthly Magazine 15:5 (September 1893), 523.

19 | Due to high visitor numbers (22.5 million), the fair went into a second largely identical - season from May 26 to October 31, 1934.

20 | Martin V. Melosi: Coping with Abundance. Energy and Environment in Industrial America. Philadelphia: Temple University Press, 1985, 112. 
audience the nature and significance of scientific discoveries, the methods of achieving them and the changes which their application has wrought in industry and in living conditions." ${ }^{21}$ In order to overcome the competitive nature of foregone fairs, they stressed the cooperative element among nations and companies and between science and industry that had brought about "A Century of Progress". Rufus C. Dawes, President of the Organizing Committee, formulated the fair's concept and purpose in the following words:

"The Exposition follows no pattern of former fairs; the competitive idea of other fairs is not in the modern spirit. [...] The one great motif of A Century of Progress is the rise of mankind during the last hundred years [.... The Story of the development of the industries that have contributed so strikingly to mankind's comfort and progress is full of high adventure and romance. It has been a swiftmoving drama recording their service to the public." 22

The fair that developed out of this approach was characterized by a general tendency toward scientification on the one hand and a strong focus on applicability of technology on the other. Both aspects were staged by new display designs realized in many cases by corporate industrial designers who relied on both their artistic and advertising skills. The importance attributed to science found its expression in the Hall of Science featuring

$21 \mid$ "A Century of Progress. Chicago International Exposition of 1933. A Statement of Its Plan and Purposes and of the Relation of States and Foreign Governments to Them", National Archives and Records Administration (NARA), College Park, MD, RG 43: Records of International Conferences, Commissions and Expositions, 1825-1979, Department of State, Bureau of International Organization Affairs, Office of International Conferences, Administrative Files, Entry 5536, Box 104, 3-4.

22 | Century of Progress International Exposition: Official Book of the Fair. Giving Pre-exposition Information 1932-1933 of A Century of Progress International Exposition Chicago 1933. Chicago: A Century of Progress, Inc., 1932, 5-6. For an elaborate discussion of scientists' role in the conceptualization of the Chicago and New York fairs see Robert W. Rydell: World of Fairs. The Century-of-Progress Expositions. Chicago: University of Chicago Press, 1993, chapter 4; Cheryl Ganz: The 1933 Chicago World's Fair. A Century of Progress. Urbana: University of IIlinois Press, 2008, 64-66. 
mathematics, physics, chemistry, biology, geology and medicine which was to

"unfold the story of the discoveries of science and invention which, within 100 years have made the forces of nature the servant of man, and which are responsible for the incredible progress in this past century; of how science has added to the comfort and safety of man and is now utilized in his service; and of the promises that it offers for future benefits to man." ${ }^{23}$

The 'deification' of science as a motor for progress and its transformational power into technological adaptations as well as humankind's assigned role in this drama found a particularly straightforward expression in the fair's motto "Science Finds - Industry Applies - Man Conforms." Materialization of this attitude became the Fountain of Science designed by Louise Lentz Woodruff and positioned at the main rotunda of the Hall of Science. According to a promotional flyer, its theme - Science Advancing Mankind - was "represented by the great robot-like figure typifying the exactitude, force, and onward movement of science, with its powerful hands at the backs of the figures of a man and a woman, representing mankind." ${ }^{24}$

The world that the fair of 1933 painted was scientifically, industrially, socially and implicitly politically progressive. The strong belief in modernization based on the use of abundant energy resources found expression both in architectural and exhibitionary terms. Energetic symbolism was prominent on the outside of the Electrical Group buildings featuring two bas-relief panels delineating, as it said in one guidebook, “man's struggle to wrest power from nature." 25 The reliefs featured two figures representing Light and Energy, the latter being inscribed: "Energy is the substance of all things - the cycles of the atoms, the play of the

23 | International Exposition Chicago 1933: A Century of Progress. Hall of Science. Chicago: International Exposition, [1932?], n. p.

24 | "Fountain of Science. Century of Progress" (1933), pamphlet, Century of Progress 1933-34 World's Fair Collection (CPWFC), University of Chicago, Special Collections, http://century.lib.uchicago.edu/images/century0061.pdf, Accessed: 22.08.2011.

25 | Century of Progress: Official Book of the Fair, 40. 
elements are in forms cast as by a mighty hand to become the world's foundations." 26

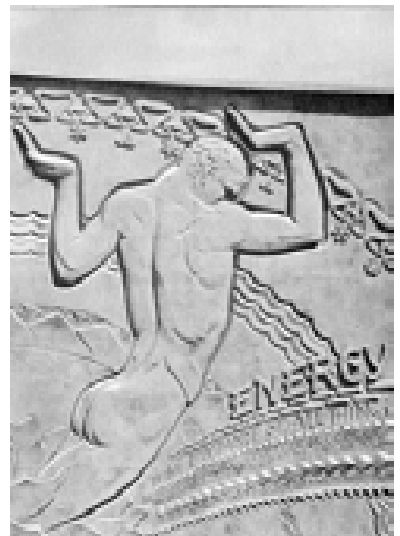

Figure 3: Bas-Relief Panel

"Energy" at the Electrical Building, Chicago World's

Fair, 1933 .

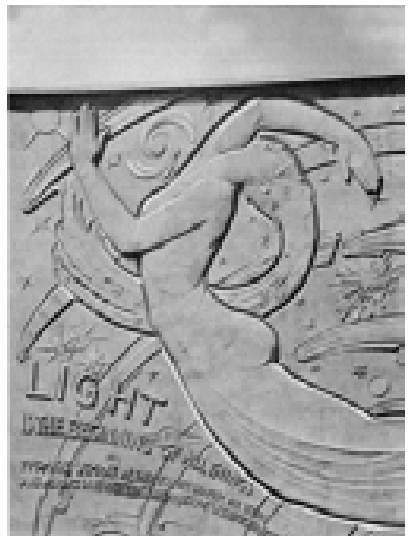

Figure 4: Bas-Relief Panel

"Light" at the Electrical

Building, Chicago World's

Fair, 1933 .

Inside the Electrical Building which was a cooperative effort of different institutions and companies of the electricity sector, the central attraction was a large diorama showing electricity's way from generation over transmission to usage. Accompanying this were many smaller dioramas ranging from historical instruments to the stylization of modern areas of application in homes, offices, shops and industrial plants. Guiding the design process had been, according to the accompanying brochure, the acknowledgment that "in the enchanting drama unfolded by this Exposition, electricity in all modesty might truthfully be cast in the role of Great Cooperator, extending to all other industry its hand of magic[.]" 27

From this view on energy resulted a two-fold approach to (electric) energy. On the one hand, exhibits aimed at transmitting a basic understanding of scientific and technological laws. On the other, they focused on what energy could do for the modernization of the private

26 | Century of Progress: Official Book of the Fair, 40.

27 | "Electricity at Work”, pamphlet, CPWFC, http://century.lib.uchicago.edu/ images/century0132.pdf, Accessed: 22.08.2011. 
household and economy. This consumptive spin on presenting energy called for new designs and exhibition styles. Not the production aspects of technologies were to be featured, but rather their applicability in everyday life, that is their desirability. The founder of Grand Canyon's Scenic Airways and member of the fair's exhibition team, J. Parker van Zandt, therefore called for less overwrought scientific exhibits in favor of simpler, easier-to-consume displays:

"Be dramatic! Whatever the story-dramatize it. [...] There is drama in everything. No product that people purchase lacks dramatic possibilities. However lifeless, prosaic and commonplace to the unimaginative it may seem, actually it is alive with warm human feelings-with the hopes, fears, and wants of the people who buy it, not as an end in itself, but as a means toward the satisfaction of their desires. The ability to see inanimate things living, which other men think are dead, make successful advertising-and winning exhibits." 28

Following van Zandt's credo, General Electric (GE) constructed a 'House of Magic' that accommodated objects and demonstrations dedicated to the 'science of electricity' performed by personnel of GE's research laboratories. Encoded as 'serious scientists' and/or magicians, the shows were as much vehicles for the popularization of science and the company's products as pure vaudeville-style entertainment. Though the personalized approach added to their appeal, shows like the lighting of an incandescent lamp without wire connections or the popping of corn kernels with electric 'microwaves' trivialized both the scientific processes and the practical applications in favor of mesmerizing, yet fleeting enjoyment.

While the 'House of Magic' or the musical comedy "What a Night"29 featuring a stingy husband who ends up being persuaded that electricity is in fact affordable made for good audience entertainment, manufacturers were at least equally interested in solid advertising by displaying their appliances hands-on. The ideal place for this was the Century of Progress Homes Exhibit consisting of eleven fully furnished model homes. Although the houses differed in the degree to which they presented revolutionary

28 J. Parker van Zandt/L. Rohe Walter: "King Customer at a Century of Progress", in: Review of Reviews 90:3 (1934), 24.

29 | "What a Night” (1934), pamphlet, CPWFC, http://century.lib.uchicago.edu/ images/century0156.pdf, Accessed: 22.08.2011. 
modern architecture and interior design, all of them shared the underlying tone of progressiveness resulting in elaborate technological infrastructures made possible through consequent application of scientific findings:

"In each of the eleven model houses, science has transformed what, in the century closing, was the kitchen into a laboratory of domestic science. Each is equipped with automatic refrigeration, self-regulating electric or gas ovens, dish-washing machines and electric mixers. Not the least interesting features of these sample homes, however, are that many of them were fabricated in faraway factories, simply being assembled on the exposition grounds, and all of them are tailored for modest purses." 30

According to the exhibiting companies, it was not just the use of gas- or electrically-driven appliances that marked modernity's invasion into American households, but also the employment of new building materials and modes of production. However, as Brian Horrigan has pointed out, there was an ambivalence inherent in the model homes' exhibition. While the homes equipped with refrigerators, washing machines, kitchen 'laboratories' and remote-control windows fascinated the visitors, they remained essentially a utopian dream in light of pressing economic needs. ${ }^{31}$ It was therefore mandatory for the fair's organizers to provide a mental bridge between the audience's often stark living reality and the dream world of the exhibited homes. They did this by incorporating presumably affordable homes such as the single-family home designed by Howard Fisher for General House, Inc. Relying on standardized massproduced building parts assembled on site, these houses were supposed to fulfill the American homeowner's dream for thousands of average-income families. ${ }^{32}$ While these houses were advertised as modern in design and comfort, most manufacturers and architects simultaneously made sure not to distance themselves from the audience's rather conservative image of an

30 | Chicago and the World's Fair 1933. Chicago: T. Husum Publishing Co., 1933, 57.

31 | Brian Horrigan: “The Home of Tomorrow, 1927-1945”, in: Joseph J. Corn, ed. Imagining Tomorrow. History, Technology, and the American Future. Cambridge: MIT Press, 1986, 145.

32 | General Houses, Inc. Pamphlet, 1933, CPWFC, http://century.lib.uchicago. edu/images/century0106.pdf, Accessed: 22.08.2011. 
ideal family home - practical, affordable, not too fancy in architecture and furnishing.

Not so, however, George Fred Keck whose 'House of Tomorrow' blew people's imagination in many ways. His house was boldly different and suggested a completely new way of living in tune with the evolving automobile culture. "Admittedly experimental, to test the reactions of visitors [...] to a house that entirely upsets the conventional ideas of a home" 33 , the 'House of Tomorrow' was built around a central utility core, twelve-sided, steel-framed, completely glazed and fully air-conditioned. While the base floor offered room for both a garage and an airplane hangar, the top floor was entirely taken up by a sundeck and observatory. It was the middle floor where the living rooms, kitchen and bathroom - radiating like cake wedges from the utilities core - were to be found. Just as airconditioning and central heating was pronounced as a given in the 'House of Tomorrow', state-of-the-art electric and gas-driven appliances were presented as must-haves and future standard.

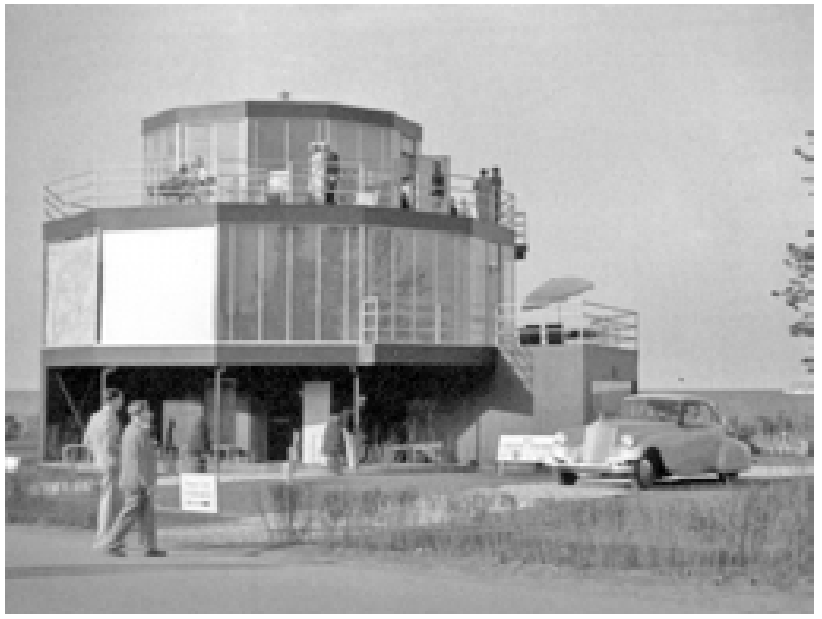

Figure 5: House of Tomorrow, Chicago World's Fair, 1933.

In its promotional brochure, the house's construction company Century Homes Inc. predicted that air-conditioning systems like the one used by Keck

33 | Kaufmann \& Fabry Co.: Official Guide Book of the World's Fair of 1934. Chicago: A Century of Progress International Exposition, 1934, 104. 
would soon "be considered as necessary as central-heating and bathrooms are today." 34 While this proved to be ahead of its time since air-conditioning would not become widely diffused in American private homes until the 1960 s, many of the other appliances shown in the model homes and the adjacent Home Planning Hall sent the simple, but intriguing message that progress was just around the corner for every American citizen.

In a way, model homes did more for utility companies and appliance manufacturers than any 'House of Magic' ever could have done: They staged and sold a walkable, even touchable dream of modern living based on the assurance that the narrative of energy abundance had an equivalent in the material world. The fact that the production, the transportation of centrally manufactured building parts and the operation of these homes were highly energy-intensive was largely disregarded by producers and consumers alike. At the Chicago fair of 1933, energy was an emblem for modernity and progress finding its expression in artistic and architectural symbolism as well as down-to-earth hands-on appliances. Together, they painted a picture-perfect domestic life for those willing to let modern energy forms, particularly electricity, and corresponding consumer technologies into their lives.

\section{New York World's FaIR, 1939-1940 35}

In many respects, the New York world's fair built upon the concepts, designs and messages of its younger Chicago brother. Its two blockbuster

34 | Century Homes Inc. House of Tomorrow. Chicago, 1933, pamphlet, CPWFC, http://century.lib.uchicago.edu/images/century0094.pdf, Accessed: 22.08.2011.

35 I Similar to the Chicago fair, the New York World's Fair reopened for a second season from May to October 1940. Different from Chicago, the second season showed some major changes in the displays; most notably the dismantling of the Soviet Union's pavilion after the country had invaded Finland in November 1939. Germany - officially citing budget restraints - had not participated at all. Overall, the second season clearly stood under the impression of world events giving itself the new motto "For Peace and Freedom" and was characterized by stronger nationalistic tones. This article focuses on the displays as they were featured in the 1939 season. 
attractions - the diorama "Democracity" in the Perisphere and GM's "Futurama" ${ }^{36}$ - have intrigued both contemporaries and scholars alike. However, there is also much to say about the presentation of energy narratives and modern consumption society when turning towards lesser known pavilions. In fact, what distinguished New York from Chicago was its radical move towards the abundance narrative in interior displays as well as architecture. Most of the energy-related exhibits were situated in the power and distribution zone devoted "to industries whose task it is to transform natural resources into commodities necessary to the daily life of whole populations." 37

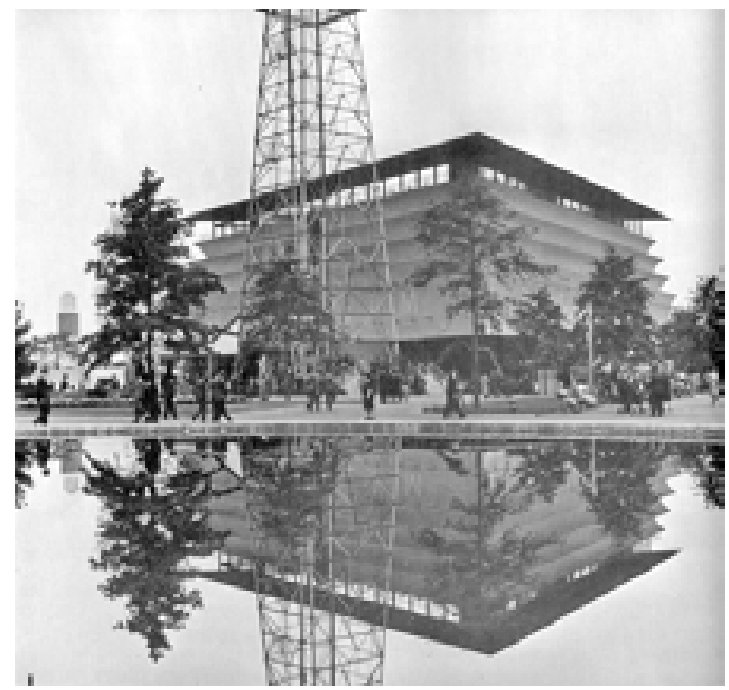

Figure 6: Petroleum Industry Building, New York World's Fair, 1939.

36 | Both "Democracity" and "Futurama" have been analyzed extensively in previous studies. See Robert Rydell: World of Fairs, 135; Roland Marchand: "The Designers Go to the Fair, II: Norman Bel Geddes, The General Motor 'Futurama', and the Visit to the Factory Transformed", in: Dennis P. Doordan, ed. Design History. Cambridge, MA: MIT Press, 2000, 103-21.

37 | Frank Monaghan: Official Guide Book New York World's Fair. New York: Exposition Publ., 1939, 139. 
Aside from the usual suspects like Westinghouse and GE, cooperative exhibits of the gas and petroleum industries as well as public utilities presented themselves in this zone. Their displays often relied on timeproven and straightforward exhibitionary approaches such as historical comparisons to emphasize the progress that electricity had brought or plain showrooms such as Westinghouse's display of state-of-the-art electrical kitchens and GE's electric appliance store. Beyond this hands-on approach, however, was a remarkable tendency towards abstraction and utopianism. The architecture of the production zone buildings featured striking references to those natural resources on which the respective industries were dependent and the technological tools with which they were extracted from the earth. While the Petroleum Industry Building rested on four huge oil tanks and exhibited an oil derrick in operation on the lawn outside ${ }^{3}$, the Gas Exhibits Building featured high towers from which gas flames shot into the sky.

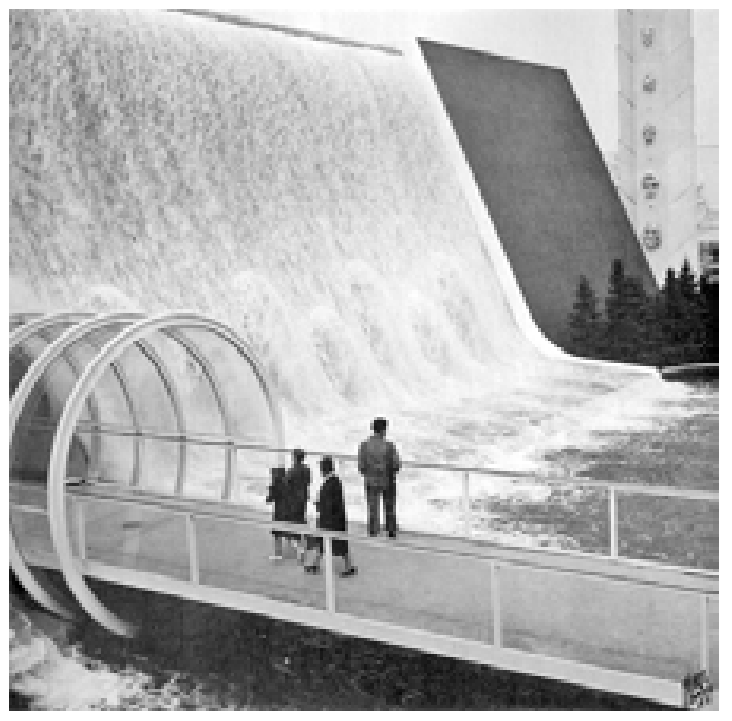

Figure 7: Electric Utilities Building, New York World's Fair, 1939.

38 | "The Petroleum Industry at the New York World's Fair...", pamphlet, Smithsonian Institution, National Museum of American History, Archives Center (SI), Larry Zim World's Fair Collection, 1841-1988, Box 1. 
This "Court of Flames" was the gateway to an exhibit "presenting the true story of Gas, the modern magic that has made life modern for America [...] the fuel that is as modern as tomorrow." 39

The Electric Utilities Building featured a massive waterfall running into a basin, the visitors entering the building through a glass spillway beneath parts of the waterfall. While giving a sense of the force of the water used for electricity generation, the tunnel enabling visitors to walk through it unharmed symbolized the conquest of this natural power. Inside, the building showcased the results of this mastery by means of a massive two-fold diorama with a live cast comparing a historical and a modern street scene to demonstrate the enormous comfort of living that electricity had brought in less than half a century. The separation between outer architecture focusing on nature's resources and interior displays featuring spaces of application corresponded with the growing detachment of energy's generation from its consumption practices in private homes, offices and shops. While the buildings claimed to be devoted to the allencompassing story of energy production, distribution and consumption, they actually bore witness to society's increasingly fragmented view on energy. Architectural elements such as the oil derrick or the waterfall served as shortened symbols for the narrative of energy abundance that had decoupled consumption from the effects of production. There was no oil dirtying the grass in front of the petroleum building and no smoking stacks of gas plants clouded the air. Instead, the visitors were confronted with an abstract rendering of energy in which nature was estheticized and artificially re-pasted into the picture. The stainless steel lightning bolt in front of GE's building symbolized the "taming of the savage natural forces of electricity to serve the needs of men" ${ }^{\circ}$ as did the showing of ten million volts of man-made lightning. What had long been considered magical beyond human beings' comprehension had turned into a force controlled by "research and engineering in electricity that will provide, for the WORLD OF TOMORROW, even more goods for more people at less cost." ${ }^{11}$ Hence, the formerly natural sublime had turned into the technological sublime by the exhibitions, "push[ing] the audience over the line from ordinary reality

39 | "Meet me at the 'Court of Flame' New York World's Fair 1939", pamphlet, SI, Larry Zim World's Fair Collection, Box 1.

40 | Monaghan: Official Guide Book, 148.

41 | New York Herald Tribune, 30.04.1939, 22. Emphases in original. 
toward a simulated dream world in which everything seemed possible" and where the terror of the natural sublime had been eliminated. ${ }^{42}$

Coupled with the powerful expressions of future urban living based on the use of abundant energy, not the least for mass automobilism, these architectural renderings of energy created the vision of a smooth production and consumption cycle. Technology had set the stage and apparently both the exhibition creators and the millions of visitors exploring the fairgrounds wanted to believe that modernity, progress, well-being and a high living standard could and would be theirs at no cost at all.

\section{Brussels 1958}

Of course, the Second World War destroyed all utopian dreams envisioned in the 1930s. By the time the first postwar fair opened in 1958 in Brussels, Belgium, the geopolitical situation had changed dramatically. Victorious over Germany and the axis powers, the Western world now faced new enemies. In the ensuing Cold War that pitted the United States against the Soviet Union, private consumption became a decisive issue. The fair was also marked by the recent war experience that had not only shaken people's trust in the project of modernity, but also their beliefs in science and technology's benign nature. To formulate a new relationship between science, technology and humankind and regain confidence in scientific achievements and applications became the theme of the fair, making it "a declaration of faith in mankind's ability to mold the atomic age to the ultimate advantage of all nations and peoples." 43 However, the International Hall of Science, intended to overcome nationalistic rhetoric and to emphasize instead international cooperation in the research on basic science, failed to capture the public's imagination. ${ }^{44}$

42 | Nye: American Technological Sublime, 216, 224.

43 | "The Brussels World's Fair 1958”, brochure, SI, Larry Zim World's Fair Collection, Box 1.

44 | Brigitte Schroeder-Gudehus/David Cloutier: "Popularizing Science and Technology During the Cold War: Brussels 1958", in: Robert W. Rydell/Nancy Gwinn, eds. Fair Representations. World's Fairs and the Modern World. Amsterdam: VU University Press, 1994, 163, 167. 
In terms of the energy narrative, the Brussels fair proves to be an interesting case. In essence, it was an expression of what Nye has called the narrative of human ingenuity. The need for abundant energy resources had become obvious to all nations during the war. Especially in Europe, the scarcity of energy supply had affected not just the military, but also the civilian population in their battle for survival in the immediate postwar years. Even though the United States had not been affected by this as much as Europe, there was a fear of energy scarcity curbing the economy and thus endangering the standard of living. Seizing upon this opportunity, the exhibition designers presented the American dealings in atomic energy entirely in scientific and peaceful terms, albeit of course simultaneously trying to keep rivaling nations from getting involved in atomic energy. At the fair, the new energy source was presented with a "mechanistic approach" explaining scientific laws in a matter-of-fact way and leaving out social, political and environmental implications. ${ }^{45}$ Aside from the Hall of Science ${ }^{46}$ and the iconic Atomium whose lower globes were home to exhibitions on atomic energy, nuclear power was featured in the British, French, Soviet and American pavilions. The American treatment was part of the pavilion's concept of small display units and basically recycled elements of the "Atoms for Peace"-exhibitions that had toured European countries earlier. Covering about 10 percent of the main floor, it featured samples of irradiated food, a hospital cobalt-6o-radiation unit and the audience's favorite - electro-mechanical hands for the handling of radioactive material that could be tried out by the visitors. A small cube of uranium was positioned in front of a large photograph showing railroad cars filled to the brim with coal suggesting that the cube provided as much power as 3,000,000 tons of coal. ${ }^{47}$

America's energy-related display looked progressive and optimistic, but the audience's response was not overly enthusiastic. The topic simply remained too scientific and lacked emotional appeal.

45 | Nye: Narratives and Spaces, 78.

46 | The United States presented the AGN-211, an operating nuclear research reactor with an output of 1 watt, constructed by the Aerojet General Nucleonics Corporation in California.

47 | “Islands for Living”, NARA, RG 43, Entry P 16, Box 20. 


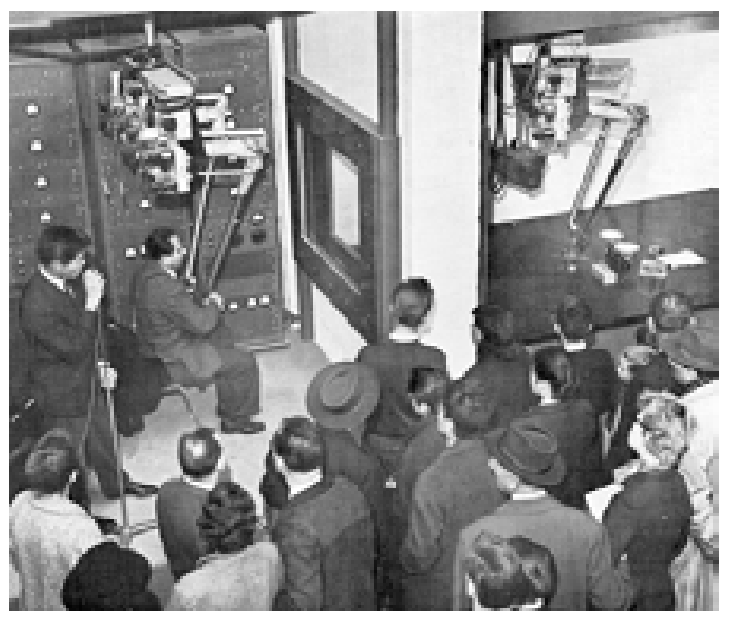

Figure 8: Nuclear Energy Exhibit, American Pavilion, Brussels Expo, 1958.

But a closer inspection of the copious American records on the displays in Brussels reveals that it was private consumption rather than atomic energy anyway with which the Americans hoped to win the hearts of the people. That the danger of falling short of the public's expectations worried many of the organizers - most of all the exhibition's commissioner general Howard S. Cullman - becomes clear in one of his warnings to an assistant to the U.S. President in December 1957 when he relayed the words of one of his aides: "It becomes more and more apparent we would be derelict in our duty if we did not point out with all possible emphasis the kind of representation the Russians plan to put on in Brussels next year. It is propaganda with a capital P." ${ }^{8} 8$ The war was apparently on and the United States decided to wage it on the terrain they knew best, America's

48 Letter of Howard S. Cullman to Honorable Sherman Adams, December 12, 1957, NARA, RG 59: General Records of the Department of State, 1763-2002, Records Relating to the Brussels Universal and International Exhibition, compiled 1956-1959, Entry 5108, Box 2. Securing a sufficient budget for the American exhibit in Brussels remained difficult. According to a German news magazine, the Soviets' investment into the fair (126 million) doubled that of the United States (63 million). “Babel in Beton”, in: Der Spiegel, 09.04.1958, 46. 
comfortable and enjoyable but also energy-intensive consumer lifestyle. In Cullman's words, they tried to "present those highlights of life in our country which are most demonstrative of ever-increasing cultural activity in the face of technologically increased leisure and our accomplishments in improving the conditions of living of every American."49

To achieve this goal, Cullman's office had brought together a special committee consisting of fifty representatives from the intellectual, industrial, academic, diplomatic and artistic elite. In conjunction with the Massachusetts Institute of Technology (MIT), five themes were developed to be exhibited in the pavilion: Land and People, Life and Work, American Idealism in Action, Culture, and Science and Technology. Providing the "ideological glue" for the exhibitions were the underlying messages that "Americans are distinctly dynamic, energetic, impatient and restless for change, and that because of the vastness of America, the diversity of our people and the free conditions pertaining to American enterprise, thought and action, we are committed to constant, unremitting search for an improved way of life." ${ }^{\circ}$ In view of the latest propaganda disaster, namely the Soviet Union's successful launching of the first human-made object into the earth's orbit, America had already dangerously fallen behind in the propaganda battle. In Cullman's opinion as he expressed it to President Eisenhower, it was of utmost importance to make sure that the Brussels fair wouldn't result in a similar debacle: "Properly handled, this could be a strong public relations weapon in combating Communist propaganda. With bungling, we could have a bombshell that could score a resounding victory for the other side. It seems to me it is vitally important to our whole foreign policy." ${ }^{51}$ Setting about their task, the exhibition design team under

49 | "Statement by Howard S. Cullman, United States Commissioner General to 1958 Brussels Universal and International Exhibition”, NARA, RG 59, Entry 5108, Box 2.

50 | "A Report on Certain Considerations Involved in the Operation of an Exhibits Pavilion at a World's Fair. Prepared by the Staff of the United States Pavilion at the Brussels Universal and International Exhibition, 1958. January 1959", NARA, RG 306: Records of the United States Information Agency (USIA), Records Relating to USIA Expositions (World's Fairs), 1959-1993, Entry 1058, Box 5, 7.

51 Howard Cullmann to President Eisenhower, November 12, 1957, NARA, RG 43, Entry P 16, Box 22. The press shared Cullman's assessment as can be seen in the many articles bearing titles such as "Fair Warning", "Big Chance at Brus- 
the leadership of Peter G. Harnden developed a multitude of small display units covering art, technology, culture, politics, food and entertainment. Situated in the airy two-level interior of the American pavilion designed by Edward D. Stone, some of the individual thematic clusters dealt with automation, color television, city and industrial planning and typical American shopping in the so-called 'Streetscape'. An American dinerlike restaurant and voting machines completed the 'American experience' while the "Face of America"-display gave the audience the possibility to acquaint themselves with typical American things such as a section of a California redwood, a Ford automobile, tumbleweed, the first Edison electric light bulb, a gold nugget or an Idaho potato..$^{2}$ All of these exhibits were supposed to contribute to a favorable picture of the United States by adhering to six basic guidelines: avoid fragmentation - positive approach accent on the future - subtle approach - visitor reference point - economic integration in the United States.53

In the conflict between the Western and Eastern bloc that was a cultural as much as a political and technological battle, home furnishings and lifestyle consumer goods soon became flagships of their respective system. It comes as no surprise, therefore, that kitchens and their appliances also found their way into the American pavilion at the Brussels fair. That a kitchen embodies "the ideology of the culture to which it belongs" 54 was especially relevant for design team member Katherine Howard, who early on argued for a fullfledged model kitchen like the ones displayed at Marshall Plan-sponsored exhibitions in Germany and other West European countries:

"[W]e must not lose sight of the fact [...] that first and foremost we are engaged in a psychological battle to win the uncommitted nations to the free way of life. [...] It is one of the wonders of the world that Americans in every economic strata

sels", "Empty Show Window at Brussels?", "Uncle Sam in the Shade", “Our Best Diplomacy!" and "Let's Show Reds" to be found in the clippings collection with the NARA Records, RG 59, Entry 5108.

52 |"A Report on Certain Considerations", NARA, RG 306, Entry 1058, 10.

53 | "Theme Development. Staff Discussions, November 6, 1956”, NARA, RG 43, Entry P 16, Box 8, 2.

54 | Ruth Oldenziel/Karin Zachmann: "Kitchens as Technology and Politics: An Introduction", in: Oldenziel/Zachmann, eds. Cold War Kitchen. Americanization, Technology, and European Users. Cambridge, MA: MIT Press, 2009, 2. 
have kitchens with labor-saving devices which free the American woman from drudgery, which make the kitchen the heart of the home." 55

Howard's conventional approach to exhibition design, however, lost against the more experimental visions of Harnden and Cullman. ${ }^{56}$ Nevertheless, her idea to showcase the manifold consumer choices open to Americans of any social and economic standing was incorporated and even taken to another level in the "Islands of Living." Here, over 1,000 objects - household appliances, toys, sports goods, office equipment and general gadgets - were displayed, demonstrating "not only the high design standards and beauty of America's everyday living equipment, but also diversity, utility and convenience." 57

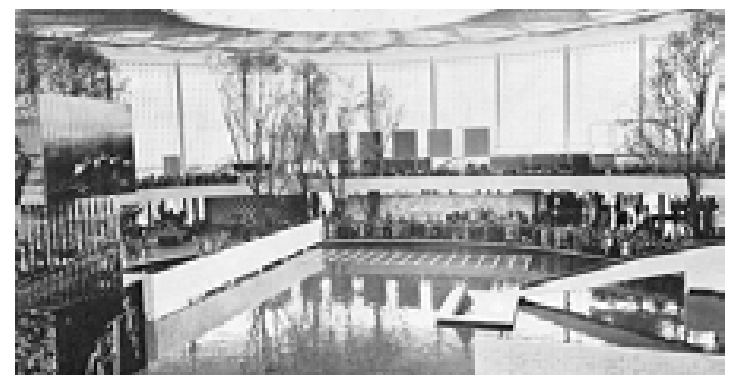

Figure 9: View from the Balcony onto Ongoing Fashion Show, American Pavilion, Brussels Expo, 1958.

Part of this concept was a fashion show which took place several times a day and regularly drew high numbers of spectators. Dressed in the latest American fashion, models paraded through the islands, interacted with the

55 | Howard to Cullman, memo, October 31, 1957, Katherine G. Howard Papers, Dwight D. Eisenhower Library, Abilene, KS, Box 25, Folder "Confidential Mrs. Howard”, p. 1, qtd. in Robert Haddow: "Material Culture Exhibits in the American Pavilion at the 1958 Brussels World's Fair: Women's Clothing, Men's Gadgets, Hot Dogs and Haute Couture", in: Popular Culture in Libraries 2:3 (1994), 64.

$\mathbf{5 6}$ | For an account on the debates about the kitchen display see Robert $\mathrm{H}$. Haddow: Pavilions of Plenty. Exhibiting American Culture Abroad in the 1950s. Washington, DC: Smithsonian Institution Press, 1997, chapter 6.

57 | “A Report on Certain Considerations”, NARA, RG 306, Entry 1058, 13. 
objects and descended from the balcony level onto a slab across the pool at the center of the pavilion.

In the tense climate of the Cold War, this strong focus on consumption and lifestyle provoked mixed reactions. A flood of letters reached the American commissioner general and the American President in the weeks and months after the fair's opening. Many of them complained about the fragmentary design of the exhibits, the too subtle 'propaganda' lacking informational give-away brochures for foreign visitors and the meaningless fashion show..$^{5}$ Instead of "useless street signs and other odds and ends", some citizens called for "model homes, furniture, appliances, automobiles, trailers, camping and barbecue equipment [... demanding to] show American life as it really exists, and pride automatically will replace our shame." 59 These often bluntly voiced opinions were supported by official audience evaluations stating that the American pavilion in almost all respects was outranked by that of the Soviet Union. The fashion show, despite having drawn high numbers, actually ranked first as the least-liked display in the entire pavilion. ${ }^{60}$

Even though neither the displays nor the controversy ensuing around it really centered on the atomic energy exhibit, the American pavilion nevertheless had a great significance for postwar energy history as it was exactly this subliminal character of the energy narrative underlying the exhibition that would become important. The American pavilion celebrated consumption practices that would become a model for many Western European societies ${ }^{61}$ in the years to come and thus contributed to the spreading of a careless high-energy consumption mentality. While the scientific background of potentially infinite energy resources by means of

58 I Letter from Jaquelin $\mathrm{H}$. Hume to the President of the United States, September 23, 1958; Letter from Arthur Cherkin to Gerson H. Lush, Department of State, June 26, 1958; both NARA, RG 43, Entry P 16, Box 11.

59 | Letter by Richard Van Zele to the Department of State, June 7, 1958, NARA, RG 43, Entry P 16, Box 11.

60 | Program and Media Studies PMS No. 29, "Visitor Reaction to the United States versus Major Competing Exhibits at the Brussels International Fair", Office of Research and Intelligence, USIA, July 1958, NARA, RG 43, Entry P 16, Box 11.

61 See Victoria de Grazia: Irresistible Empire. America's Advance through $20^{\text {th }}$ Century Europe. Cambridge, MA: Belknap, 2005; Oldenziel: Cold War Kitchen. 
nuclear fission had been meant to take center-stage at the Brussels fair, it was really the lifestyle in reach for an increasing number of people based on "diversity, mobility, portability and disposability" ${ }^{2}$ that made people go into raptures. Behind fashion, food and fun, energy in its physical and technological nature disappeared out of sight as if bikinis, hamburgers and television sets were entirely energy-insensitive in production and consumption. In the end, the American pavilion left its visitors with the impression and confidence that energy abundance was secured by the means available to scientists and engineers and that consumer paradise was just around the corner for everyone and - yet again - at no sacrifice at all.

\section{International Energy Exposition, Knoxville, 1982}

This assessment would of course change dramatically over the next two decades. As the postwar economic boom set in, bringing industrialization to more countries around the world, the demand for cheap energy sources increased dramatically. Finally, in the 1970 s the world was shaken by the oil price crises that - for many rather abruptly - turned the narrative of abundance into one of scarcity. ${ }^{63}$ Whether the energy shortage was due to natural causes as the world approached peak oil or a result of artificially constructed limitations of supply is irrelevant for this paper. What matters is that energy was high on the agenda of politicians and economists and vividly present in the media. It comes as no surprise, therefore, that the exposition in 1982 taking place in Knoxville, Tennessee was chosen to run under the theme "Energy Turns the World." Modeled in many respects on the 1974 Spokane world's fair which had distanced itself from technocratic approaches and focused on the topic "Celebrating Tomorrow's Fresh New Environment", the Knoxville fair was conceived by local businessman and executive director of the Downtown Knoxville Association W. Stewart Evans. Although one of the smallest cities ever to host a world's fair, Knoxville was by no means an accidental choice. Home to the University of Tennessee's energy research center and the Tennessee Valley Authority's headquarters, the city was also close to the Oak Ridge's National Atomic Laboratory

62 | “Islands for Living”, NARA, RG 43, Entry P 16, Box 20.

63 | Nye: Narratives and Spaces, 80. 
and rich oil fields in the surroundings. Despite its topical motto, the fair turned out to be rather traditional, uninspired, even boring if we believe contemporary assessments. Although many of the participating nations made an effort to incorporate the theme into their presentations, most of them ended up re-activating the same cultural displays that had been a staple for over 50 years.

Despite its limited significance for the history of world's fairs in general, the Knoxville exposition is interesting for the topic of this paper as it signifies the shift of energy narratives in the 1970s and 80s in the United States. Firmly anchored in Republican energy politics, the fair of 1982 gave expression first to the narrative of artificial scarcity brought about by foreign hands to be remedied by human ingenuity only to finally return to energy abundance and security.

The primary stage for this succession of narratives from scarcity to abundance by way of ingenuity was the American pavilion which was supplemented by the landmark building of the fair, the Sunsphere. This steel tower topped with a glass globe symbolized the sun and its enormous energetic potential. Inside, however, there were no exhibitions but two observation desks, a dining room, a restaurant and their kitchen. Huge solar collectors on the roof provided power for the air conditioning and hot water system.

The pavilion told America's "energy story" presenting all nine energy sources used in the United States at that time in separate glass towers. Artifacts "suspended in a beam of light" were joined by photographs and a multi-media presentation depicting "a geographical survey of our nation's abundant energy resources.” Energy as basis for America's technological advancement and society's affluence was the underlying statement of another display in which historical artifacts ranging "from a metal bed warmer used in 1816 to parts from an IBM-360 computer" showed "energy's importance as a central factor in our society's growth."64 Again, energy abundance and modernity, progress and material comfort were so closely linked as to not allow for any critical questioning. Ten years after the appearance of The Limits to Growth (1972) and Jimmy Carter's call to "balance our demand for energy with our rapidly shrinking resources", economic growth and energy consumption were still inextricably linked

64 | United States Department of Commerce Expo '82 News: "The Energy Place”, SI, Larry Zim World's Fair Collection, Box 38. 
in the designs of the pavilion's displays. What had been declared a "test [of] character of the American people" and a "moral equivalent to war" by Carter had been reduced to lip-service to conservation and efficiency efforts by the exhibition designers. ${ }^{6}{ }^{5}$ The story told in the American pavilion was not so much about past mistakes or necessary adjustments in politics and practices, but rather a reaffirmation of the capitalist energy-intensive society powered by fossil resources and well-established technologies only to be supplemented, not substituted by renewables.

Oil price crises, scarcity and environmental problems were presented as mere bumps in the road to eternal energy bliss while technology was seen as the key to mastering temporary bottlenecks in supply. In fact, it was not so much the energy resource but rather the technology used for its exploitation that was center-staged in Knoxville. This also became clear in corporate exhibits by Sun Co. (Sunoco) featuring solar energy technology, Occidental Petroleum and Tenneco, Inc. showing the extraction of oil from shale or United States Steel's Oilwell Division which exhibited the 'good old' oil well that had already done the job in Chicago in 1933. All these displays relied on the expressive power of technology as humanity's tool in the advancement of civilization.

Consumption practices clad in the untouchable premise of economic growth and a rising standard of living were not questioned. Even efforts in energy efficiency and conservation were propagated not in terms of saving but 'freeing' energy, making it available for even more consumption and industrial growth. The "Home of the Future" by Cathedralite Inc., for instance, was fitted with a state-of-the-art heat reflective roof system, insulated shades, a heat pump for climate control, but also with a machine park of KitchenAid appliances. ${ }^{66}$ The message of this arrangement was clear: Save energy by using efficient technology and you may use as much energy as you like without feeling guilty or having to fear shortages.

Perhaps the most political of the fairs examined in this paper, the Knoxville exposition that had been initiated by Democrat Jimmy Carter "to

65 | Television Speech by President Jimmy Carter, April 18, 1977, WGBH American Experience, http://www.pbs.org/wgbh/americanexperience/features/prima ry-resources/carter-energy/, Accessed: 04.07.2011.

66 | Press Release Sher, Jones, Shear and Associates Inc., SI, Larry Zim World's Fair Collection, Box 38, 3. 
think anew of man's relationship with the pervasive force of energy" ${ }^{\prime 6}$, turned out to be clearly marked by Republican energy policies. Redefining his predecessor's existential narrative as a narrative of artificial limitation brought about by foreign enemies and misguided policies at home, Ronald Reagan used the fair for propagating energy-intensive production and consumption as assurance against industrial decline, impoverishment and communism:

"We have seen the havoc and felt the pain brought on when vital energy sources outside our influence have been cut off. We have seen our economies manipulated, our industries hamstrung and our people squeezed between scarcity and inflation. [...] The previous administration tried to manage a shortage by interfering with the market process. [...] [I]f America is to provide for her energy security, if we are to continue growing more self-reliant, if we are to free ourselves form foreign pressure, we must press toward the ultimate solution to our energy problems: The decontrol of all our energy sources[.]"68

The Knoxville exposition thus forfeited its chance of redefining both the energy narrative and the display modes to convey it. In a way, it even represents a regression from the de-technologized landscapes of modern living that had characterized the American pavilion in 1958. In contrast to Brussels, the Knoxville displays focused on technology as a salutary force in the fight against energy limitations. Simultaneously architectural element and artifact, the individual technological objects displayed were a symbol for America's - real or faked - belief in the omnipotence of technology to overcome any obstacle while remaining silent on any negative consequences for environment, society and culture. It comes as no surprise that the world did not remember Knoxville 1982 for its role in the environmentally informed energy discourse, but for the introduction of 6o-minute color photo processing and Cherry Coca-Cola. ${ }^{69}$

67 | “The Exposition”, press kit, SI, Larry Zim World's Fair Collection, Box 56, 3.

68 | The White House, Office of the Press Secretary: "Remarks by the President at the Opening of the 1982 World's Fair”, May 1, 1982, SI, Larry Zim World's Fair Collection, Box 38, 1-3.

69 | "The 1982 World's Fair. You've Got to Be There!", NARA, RG 306: United States Information Agency, Records Relating to Universal and International Exhibitions, compiled 1966-1999, Entry 1092, Box 2, 3-4. 


\section{Conclusion}

Surveying energy-related displays by governments and companies over the course of almost a century of world's fairs, it has become clear that primarily two types of discourses have been at work. One is the blatantly promotional discourse of utility companies and consumer goods manufacturers. The other one, less overtly but nonetheless influential, is the general narrative of energy abundance underlying even those displays that are seemingly unrelated to energy issues or those emphasizing human ingenuity and/ or energy scarcity. Both discourses depend upon each other, but it is the hidden one that has influenced the way we think about and consume energy. The American world's fairs' significance lies in their construction and communication of a careless attitude towards energy consumption which may or may not have been consciously pursued, but which surely served as a role model for many societies. From the early presentations of electricity in Chicago to atomic energy in Brussels to renewable energy technologies in Knoxville, the fairs have perpetuated energy narratives and to some extent contributed to growing energy oblivion. No matter which energy source we are dealing with, the narrative of natural abundance - or its transformed version of ingenious engineering that secures and prolongs that abundance - is shaping the displays. Aided by historical circumstances, industrial and private energy consumption was inextricably linked to economic growth, social progress and individual comfort in all of the fairs discussed.

Nevertheless, although the underlying message stayed the same, the modes of mediation by exhibitionary means changed. While early displays of electricity had been meant to educate and familiarize with a completely new energy source, later fairs concentrated on the contextualization of energy - especially electricity - as fundamental prerequisite for everything that was good about America: modernity, prosperity, democracy. For a certain time in the first half of the $20^{\text {th }}$ century, the technological object was pushed back in favor of the display of readymade consumer goods and utopias of modern living. Understanding how things worked became less important; one only needed to know how to use them. Instead of singular objects, dioramas, mural art and model homes created 'landscapes' of modern life that presented production and consumption as a seamless 
process devoid of friction. ${ }^{70}$ Culminating in Brussels, exhibition makers reduced energy technologies to an adjunct of their displays paying tribute to what might be called the 'consumption sublime'.

The energy crises of the 1970s and to some extent the beginning environmental movement could not go unnoticed by world's fairs. However, they did not result in a revision of consumption practices - at least not on a large scale - but rather in a return of the technocratic outlook. The problems - and there were many - would be solved if only scientists, engineers, industrialists and consumers believed in technology again. The practices of how this energy technology was used, which technology was to be favored and how to save energy instead of shifting the resources to be tapped was not prioritized. The average consumer as actor in the drama of energy was left out of the picture in most of Knoxville's displays.

Having taken a look at the world's fairs discussed in a long line of development, it becomes clear that energy has been dematerialized over the course of the $20^{\text {th }}$ century. As the processes of its production and distribution became disconnected from peoples' lives, energy was reduced to a commodity coming out of wall-sockets. The raw materials depleted for the production of energy - coal, gas, oil, uranium - and the risks connected with them, were shunned. The fixation on the consumption aspects resulted in increasingly scenic presentations that favored vision and hearing over tactile sensation. Finally, and this makes exhibitions so intriguing to study, these developments at the same time prevented the complete abandonment of object-centered displays. It was exactly because of the tendency towards scenography that model homes retained their popularity. Both modes of presentation prove to be mutually dependent in the world's fairs of the $20^{\text {th }}$ century: While the 'landscapes of experience' created imaginative visions permeated with ideology, object-centered displays offered tangibility and points of identification in an increasingly complex (energy) world.

70 | Laura Burd Schiavo: “Modern Design Goes Public. A Photo Essay”, in: Robert W. Rydell, ed. Designing Tomorrow. America's World's Fairs of the 1930s. New Haven, CT: Yale University Press, 2010, 122. 


\section{BIBLIOGRAPHY}

\section{Archival Sources}

National Archives and Records Administration (NARA), College Park, MD, USA

RG 43 Records of International Conferences, Commissions and Expositions, $1825-1979$

RG 59 General Records of the Department of State, 1763-2002

RG 306 Records of the United States Information Agency (USIA)

University of Chicago, Special Collections, Century of Progress 1933-34 World's Fair Collection, http://century.lib.uchicago.edu/

Smithsonian Institution, National Museum of American History, Archives Center, Washington, DC, USA

Larry Zim World's Fair Collection, 1841-1988

Daniel H. Meyerson World's Fair Collection, 1962-1982

\section{Published Sources and Secondary Literature}

Adams, Judith A. "The Promotion of New Technology through Fun and Spectacle: Electricity at the World's Columbian Exposition", in: Journal of American Culture 18:2 (1995), 45-55.

Bancroft, Hubert Howe. The Book of the Fair. Chicago: Bancroft, 1893.

Carter, Jimmy. Television Speech, April 18, 1977, WGBH American Experience, http://www.pbs.org/wgbh/americanexperience/features/primaryresources/carter-energy/, Accessed: 04.07.2011.

Century of Progress International Exposition. Official Book of the Fair. Giving Pre-Exposition Information 1932-1933 of A Century of Progress International Exposition Chicago 1933. Chicago: A Century of Progress, Inc., 1932.

Chicago and the World's Fair 1933. Chicago: T. Husum Publishing Co., 1933.

Cravath, J. R. "Electricity at the World's Fair", in: Review of Reviews (July 1893), 35-39.

Doenecke, Justus D. "Myths, Machines and Markets: The Columbian Exposition of 1893", in: Journal of Popular Culture 6:3 (1973), 535-49.

Ganz, Cheryl. The 1933 Chicago World's Fair. A Century of Progress. Urbana: University of Illinois Press, 2008. 
de Grazia, Victoria. Irresistible Empire. America's Advance through $20^{\text {th }}$-Century Europe. Cambridge, MA: Belknap, 2005.

Haddow, Robert H. Pavilions of Plenty. Exhibiting American Culture Abroad in the 1950s. Washington, DC: Smithsonian Institution Press, 1997.

Haddow, Robert: "Material Culture Exhibits in the American Pavilion at the 1958 Brussels World's Fair: Women's Clothing, Men's Gadgets, Hot Dogs and Haute Couture", in: Popular Culture in Libraries 2:3 (1994), 39-87.

Halstead, Murat. "Electricity at the Fair", in: The Cosmopolitan. An Illustrated Monthly Magazine 15:5 (September 1893), 577-83.

Horrigan, Brian. “The Home of Tomorrow, 1927-1945”, in: Joseph J. Corn, ed. Imagining Tomorrow. History, Technology, and the American Future. Cambridge: MIT Press, 1986, 137-63.

International Exposition Chicago 1933. A Century of Progress. Hall of Science. Chicago: International Exposition, [1932?].

Kaufmann \& Fabry Co. Official Guide Book of the World's Fair of 1934. Chicago: A Century of Progress International Exposition, 1934.

Korff, Gottfried. "Scheinkapellen u. ä. Sieben Bemerkungen zu den diskursiven und visuellen Strategien des Geschichtsmuseums im Jahrhundert seiner Etablierung", in: Bernhard Graf/Hanno Möbius, eds. Zur Geschichte der Museen im 19. Jahrhundert; 1789-1918, Berlin: G+H Verlag, 2006, 111-23.

Krasny, Elke. “Zukunft ohne Ende: Das Unternehmen Weltausstellung”, in: Brigitte Felderer, ed. Wunschmaschine Welterfindung. Wien: Springer, $1996,314-38$.

Marchand, Roland. “The Designers Go to the Fair, II: Norman Bel Geddes, The General Motor 'Futurama', and the Visit to the Factory Transformed”, in: Dennis P. Doordan, ed. Design History. Cambridge, MA: MIT Press, 2000, 103-21.

Melosi, Martin V. Coping with Abundance. Energy and Environment in Industrial America. Philadelphia: Temple University Press, 1985.

Monaghan, Frank. Official Guide Book New York World's Fair. New York: Exposition Publ., 1939.

New York Herald Tribune, 30.04.1939.

Nye, David E. “Electrifying Expositions, 1880-1939”, in: Robert W. Rydell/ Nancy Gwinn, eds. Fair Representations. World's Fairs and the Modern World. Amsterdam: VU University Press, 1994, 140-56. 
—. American Technological Sublime. Cambridge, MA: MIT Press, 1996.

- Narratives and Spaces. New York: Columbia University Press, 1997.

Oldenziel, Ruth/Karin Zachmann. "Kitchens as Technology and Politics: An Introduction”, in: Ruth Oldenziel/Karin Zachmann, eds. Cold War Kitchen. Americanization, Technology, and European Users. Cambridge, MA: MIT Press, 2009, 1-29.

Rand, McNally \& Cos. A Week at the Fair Illustrating the Exhibits and Wonders of the World's Columbian Exposition. Chicago: Rand, McNally \& Cos., 1892.

Rydell, Robert W. World of Fairs. The Century-of-Progress Expositions. Chicago: University of Chicago Press, 1993.

Schiavo, Laura Burd. "Modern Design Goes Public. A Photo Essay”, in: Robert W. Rydell, ed. Designing Tomorrow. America's World's Fairs of the 1930s. New Haven, CT: Yale University Press, 2010, 77-140.

Schroeder-Gudehus, Brigitte/David Cloutier: "Popularizing Science and Technology During the Cold War: Brussels 1958", in: Robert W. Rydell/ Nancy Gwinn, eds. Fair Representations. World's Fairs and the Modern World. Amsterdam: VU University Press, 1994, 157-80.

Der Spiegel, o9.04.1958.

This is America. Official United States Guide Book Brussels World's Fair 1958. New York: Office of the United States Commissioner General, 1958.

Walker, John Brisben. “A World's Fair. Introductory: A World's College of Democracy", in: The Cosmopolitan. An Illustrated Monthly Magazine 15:5 (September 1893), 517-27.

van Zandt, J. Parker/Walter L. Rohe. "King Customer at a Century of Progress”, in: Review of Reviews 90:3 (1934), 22-27. 


\title{
"We want to live electrically!"
}

\author{
Marketing Strategies of German Power Companies \\ in the $20^{\text {th }}$ Century
}

Sophite Gerber

Over the course of the $20^{\text {th }}$ century, Germans have turned into consumers of rapidly increasing amounts of energy in private households which became places cluttered with ever more energy-consuming gadgets. This development represents an important cultural process. Ever more mundane practices such as the storing and preparation of food or personal hygiene became dependent on the supply of electricity. Its introduction into private households and increasing consumption changed consumers' lives and environments as well as their routines. Thus, German households participated prominently in the transition towards a Western high-energy society which has gained momentum since the 1950s. But what and who contributed to Germans ending up consuming ever more electricity and adjusting their daily routines to the increasing consumption of energy?

In this paper I will argue that advertisements functioned as a crucial element and condition of the electrification and mechanization of households. According to the philosopher, sociologist and journalist Siegfried Kracauer, the analysis of advertising as

"the simple surface manifestations of an epoch can contribute more to determining its place in the historical process than judgments of the epoch about itself. [...] On the other hand the very unconscious nature of surface manifestations allows for direct access to the underlying meaning of existing conditions." ${ }^{1}$

1 | Siegfried Kracauer: “The Mass Ornament”, in: New German Critique 5 (Spring 1975), 67. 
In this sense, advertisements are directly linked to society and their decoding leads to an understanding of societal contexts, although advertising cannot be read as a true or unbiased reflection of reality. But since advertisements have to be connected and communicated with society, there is a limit as to how imaginative they can be. ${ }^{2}$ Following Kracauer's remarks, advertising is today perceived and accepted as an important source for cultural as well as economic and social history. It can be used as a crucial component of an interdisciplinary history of consumption. Although advertising is goaloriented, it is, like mundane objects, a part of everyday culture and therefore a rich source for historians. For a consumer-oriented history of technology which focuses on electricity in private households, advertisements are in fact indispensable sources since they were a crucial component and condition of electrification and the mechanization of households which so far have been investigated predominantly from a technological and economical point of view. From a historical perspective, a comprehensive contextualization of electricity advertising in Germany is a relatively new field of research. ${ }^{3}$

First and foremost, historical studies show - hardly surprisingly - that energy suppliers aimed at profits. One way to increase them was to balance the load curves of power plants. For example, installment credits for white goods were supposed to generate additional purchasing power and cheap electricity prices were offered in order to extend the demand and thus the efficiency and profitability of power companies. ${ }^{4}$ But the more important aspect for an analysis of advertising is that it is a means to charge the consumption of electricity with meaning and to make frames of meaning

2 I Cf. Herbert Willems: Rahmen und Habitus. Zum theoretischen und methodischen Ansatz Erving Goffmans. Vergleiche, Anschlüsse und Anwendungen. Frankfurt/Main: Suhrkamp, 1997, 387.

3 | For a first systematic outline see Peter Döring/Christoph Weltmann: “'Die Erweckung von Stromhunger'. Elektrizitätswerbung im 20. Jahrhundert”, in: Horst A. Wessel, ed. Das elektrische Jahrhundert. Essen: Klartext, 2002, 93-108 and Theo Horstmann/Regina Weber, eds.: "Hier wirkt Elektrizität". Werbung für Strom 1890 bis 2010. Essen: Klartext, 2010.

4 | Ludwig Koch: “Die Haushaltsgeräte-Absatzpolitik in Elektrizitäts-Versorgungsunternehmen" (Unpublished Ph.D. diss., Ludwig-Maximilians-Universität München, 1957), 11-12. Koch's work is one of the few contemporary studies on the marketing policy of electricity suppliers. 
and action visible for consumers. Following the French cultural theorist Roland Barthes, there is not only the literal meaning of advertisements, but a secondary, connotative meaning which is perceived more unconsciously and emotionally by consumers. ${ }^{5}$ Therefore, producers keep consumers in mind when creating advertisements and as a result, advertisements show designated user contexts and social as well as cultural values of a technology such as electricity. ${ }^{6}$ Therefore, an analysis of advertisements also reveals which functionalities and meanings of a technology producers and consumers appreciated and which they ignored. For example, during the 1950 s, the laborsaving effects of electricity had been appreciated but its ecological consequences were ignored until the early 1970s. ${ }^{7}$ The symbolic value and cultural context of advertisements have to be decoded and interpreted by the beholder, and the advertised product - electricity and its use - has to be related to certain symbols.

Advertising has to be considered as a mediating code which represents consumers as well as producers. In other words, advertising is "not only an impulse towards society, but a reflection of this society itself" ${ }^{8}$ or rather the reflection of the expectations of producers, advertisers and consumers and therefore it reveals predominant cultural ideals rather than social reality.

If we want to understand how German households contributed to the transition to a high-energy society and to explore the mediation processes between the production and consumption of electricity, the notion of 'mediation junctions' helps to examine the negotiation space in which utility companies, engineers, advertisers, politics and consumers shaped the development of electricity consumption during the $20^{\text {th }}$

5 | Roland Barthes: Mythen des Alltags. Frankfurt/Main: Suhrkamp, 1964, 88-96.

6 | Heike Weber: Das Versprechen mobiler Freiheit. Zur Kultur- und Technikgeschichte von Kofferradio, Walkman und Handy. Bielefeld: transcript, 2008, 78.

7 | Weber: Das Versprechen mobiler Freiheit, 78-79.

8 | Rainer Gries/Volker Ilgen/Dirk Schindelbeck, eds.: “Einleitung. Kursorische Überlegungen zu einer Werbegeschichte als Mentalitätsgeschichte", in: "Ins Gehirn der Masse kriechen!" Werbung und Mentalitätsgeschichte. Darmstadt: Wissenschaftliche Buchgesellschaft, 1995, 4. This and all following citations from German publications and sources were translated by the author. 
century. 9 Advertisements show how electricity and its use are discussed among producers and became their most important means of technology mediation, created by engineers and electricity advisers before marketing specialists took on this task since the 1950s.

Consumers and especially housewives, however, were crucial actors in the process of domestic electrification and its marketing. At the dawn of electrification a knowledge gap concerning the unknown form of energy had to be bridged by electric companies. Energy suppliers ought to educate housewives about the advantages and the use of electricity in their homes. Their aim was to find out about the desires and needs of electricity consumers and to emphasize the users' viewpoint in the production and mediation of electricity. ${ }^{10}$ Moreover, consumers developed special relations to electricity as a product. Because electricity is not storable, users satisfy their need for electricity when they actually consume it and thus determine the capacity of energy production and distribution. Their practices, the number of energy-consuming appliances they switch on, the moment when they do so and the duration of operation is reflected in the daily load curves of power plants. Therefore, producers and users of electricity developed a very specific dependence upon each other. Increasing the efficiency of energy production and thus their profits required the utilities to determine the daily routines of their consumers because not just the amount but also the time of energy use was important.

Assuming that advertisements draw a picture of the West German society which became inextricably linked to the use of electricity during the $20^{\text {th }}$ century, I want to explore which methods and strategies of advertising existed and from which social and cultural contexts these advertisements evolved. Moreover, I will ask what advertisements reveal about the intentions and impediments of electricity consumption.

This article focuses on the specifics of advertisements as an important component of marketing strategies of power companies after 1945 and examines its characteristics compared to electricity advertising before

9 | Cf. Ruth Oldenziel/Adri Albert de la Bruhèze/Onno de Wit: “Europe's Mediation Junction. Technology and Consumer Society in the $20^{\text {th }}$ Century", in: History and Technology 21:1 (2005), 107-39.

10 | Carroll Pursell: "Domesticating Modernity: The Electrical Association for Women, 1924-86", in: The British Journal for the History of Science 32:1 (1999), 47-67. 
1945. It will analyze material from Berlin's local electricity supplier Bewag, which was known by this name from 1934 to 2006 . The predecessor had been founded as Germany's first electricity company in 1884 and Berlin's central power plant went into operation one year later. In its company archives, Bewag keeps a vast amount of advertising material, press releases and reports, photographic material as well as documents related to special advertising campaigns such as the rental of electric stoves. The material will be extended by an analysis of the magazine Elektrizität, a journal for electricity customer advice published by the 'Main Advice Center for Electricity Consumption' (HEA)", to provide a more comprehensive insight into the advertising methods of energy suppliers.

\section{FoCUSING ON OBJECTS: Methods of Electricity Marketing}

Energy producers used diverse advertising methods, some of them including objects as significant agents of mediation, to promote electricity and foster customer relations. Mediation processes related to electricity, however, are different from other products because electricity does not directly appeal to the senses and we usually perceive it through devices and appliances. Today, we are especially familiar with marketing for electricity as a product in a liberalized market. ${ }^{12}$ But during the early spread of electricity, the electricity and appliance industries recognized that they could benefit from each other since they shared the objective of the complete connection of households to the grid first and the all-electric household later on. In their joint advertising campaigns until the 1960 s, their strategy of choice was to emphasize objects by advertising electricity-consuming appliances.

11 HEA saw as its purpose "to provide general education about the characteristics of electric energy and its rational use, to advise all members of the electricity industry and interested parties on this subject and to work towards the use of appliances that are technically and economically as perfect as possible", Hauptberatungsstelle für Elektrizitätsanwendung: Satzung (Fassung vom 18. März 1952). Frankfurt/Main: HEA, 1952, Archiv der HEA, Berlin.

12 | Cf. Regina Weber: "Elektrizitätswerbung zwischen Markt und Ökologie”, in: “Hier wirkt Elektrizität". Werbung für Strom 1890 bis 2010. Essen: Klartext, 2010, 318-21. 
Their cooperation aimed at increasing the number of electric appliances in households, an increase in sales for electric companies, and at establishing an extended electricity grid as a requirement and incentive for consumers to buy electric appliances for their homes.

In general, methods of advertising for electricity were more varied than advertising for other products and they were not limited to print, radio and TV campaigns. Advice and education complemented visual media such as posters and advertisements in magazines. Popular forms for Bewag's promotion campaigns, especially after 1945, were advertisements in newspapers and in public spaces, e.g. in subway stations or with the help of an advertising bus. Publications such as customer magazines and cookbooks brought the practical use of electricity closer to consumers. Installment systems, e.g. Bewag's "Elektrissima" as well as renting campaigns, were supposed to ease the introduction of electrical appliances into German households despite financial constraints. In information and advice centers, consumers could inform themselves about domestic appliances, their purpose, price, electricity consumption and handling and watch demonstrations of electric stoves, refrigerators and food processors. Training kitchens, where housewives could familiarize themselves with the efficient handling of an electric stove as well as refresh and extend their cooking skills during free cooking courses were popular. Some training kitchens were even designed to be relocated and moved from one newlybuilt residential area to another. ${ }^{13}$ A significant advantage of advice centers and training kitchens was their proximity to customers and markets. Electric cooking training was also offered in professional schools in order to address future consumers. As will be shown, promotional electricity prices had been another main characteristic of the strategies pursued by power companies. By all of these means, it was hoped that consumers could be firmly convinced of the usefulness of electricity and, beginning with the late 1950s, the all-electric kitchen. In France, promotional films as another advertising method of energy suppliers were popular. As a fruitful source for historians, they also help to reconstruct the cultural representations of energy, its consumption and consumers. ${ }^{14}$

13 | Irene Krause: “Hausfrauenwerbung in Berlin”, in: Elektrizität 9:5 (1959), 112.

14 | Cf. the contribution of Yves Bouvier in this volume. 
In the second half of the $20^{\text {th }}$ century, joint advertising campaigns of the electricity and appliance industry gradually decreased. Electricity suppliers began to use direct marketing for electricity whilst appliance manufacturers continued to advertise via objects. But the advertising strategies and motifs of both industries remained similar. Since the early 1970s, they have concentrated their campaigns on the establishment of an ecological image.

\section{Making Electricity Visible: AdVertising Electricity before 1945}

In late $19^{\text {th }}$ century Germany, entrepreneurs and engineers like the founder of the Deutsches Museum, Oskar von Miller, or Emil Rathenau, the founder of the famous producer of electrical equipment AEG, were among the first to popularize electric energy. In 1907, Emil Rathenau's son Walther stated in a letter to his father that the propagation of electrotechnical applications "has to be organized and forced on consumers by producers." ${ }^{15}$ The protagonists of electrification realized that far-reaching information campaigns by electricity companies and appliance manufacturers were required in order to promote electrification and local power networks as well as domestic mechanization. In 1886, electric domestic appliances were presented at a sample exhibition of the AEG (then Deutsche Edison Gesellschaft) for the first time. In the following year, the BEW ${ }^{16}$, Berlin's public utility founded in 1884 , opened its first permanent exhibition space with the aim of explaining electric lighting to potential customers and thus advertising it.

15 | Qtd. in Jürgen Kocka: “Neue Energien im 19. Jahrhundert. Zur Sozialgeschichte der Elektrizitätswirtschaft”, in: Evelyn Gröbl-Steinbach, ed. Licht und Schatten. Dimensionen von Technik, Energie und Politik. Wien: Böhlau, 1990, 21. 16 | Berlin's public utility A.G.StEW was founded in 1884, AEG took over its administration in 1887 and the company was renamed BEW. Beginning in 1923, Berlin's Municipal Electric Company (Bewag) operated BEW's plants and merged with Berlin Power and Light Corporation (Berliner Kraft- und Licht-Aktiengesellschaft) in 1934, renaming the company Bewag. It operated West Berlin's power network beyond the division of Berlin from 1948 until 1993. In 2003, the Swedish company Vattenfall bought the company, renaming it in 2006. 
The invisibility of electricity created fear and mistrust among consumers and hampered the process of domestic electrification. Electricity suppliers had to work hard to convince skeptical consumers and to provide the necessary knowledge about the new form of energy. ${ }^{17}$ In their advertising, companies therefore used anthropomorphisms such as magic fairies or helpful leprechauns in order to demonstrate the safe use of electricity in private households. Dancers with light bulbs and human candelabra presented the fascination of electricity at fairs and exhibitions. ${ }^{18}$ Moreover, luminous advertising on house facades promoted not only the advertised product, but the use of electricity as well. ${ }^{19}$

Early electricity advertising was confronted with two difficulties. Firstly, there was a strong competition with the petroleum, the coal and the gas industry. And secondly, private households were a new market that had to be conquered, while electrification had already found a firm footing in industry, trade, traffic and public lighting. Accordingly, the strategy the electricity companies pursued was to focus on pertinent consumer information. With the Bewag getting more and more customers, Berlin's electricity supplier published the first monthly customer magazine of a German electricity company as early as 1905. The first association for electricity advertising in Germany (Gefelek) was founded in 1911 by German electricity producers and electrical engineers. The Bewag inaugurated its first information centre in 1924 and added a training kitchen two years later, where the advantages of electric cooking were praised. Utilities began to advertise in cooperation with each other with the slogan "Electricity in every appliance" in 1927 and adjusted their campaigns to specific target groups, such as rural or urban households and craftsmen. ${ }^{20}$ Until the 1930s, exhibitions, demonstrations, posters and advertisements in newspapers were in the focus of electricity suppliers' advertising efforts. They had consumers in mind who had to become aware of the safe and inexpensive use of electricity for household appliances.

17 | Koch: Die Haushaltsgeräte-Absatzpolitik, 33-34.

18 | Döring: “Elektrizitätswerbung im 20. Jahrhundert”, 93.

19 | Döring: “Elektrizitätswerbung im 20. Jahrhundert”, 100.

20 | Christoph Weltmann: "Elektrizitätswerbung in den Zwanziger Jahren. Landwirte im Fokus und 'Elektrizität in jedem Gerät' - eine Werbemarke für Strom”, in: Theo Horstmann/Regina Weber, eds. "Hier wirkt Elektrizität". Werbung für Strom 1890 bis 2010. Essen: Klartext, 2010, 49. 
Electricity advertising was not only supposed to generate a general increase in sales, but power companies also aimed at the balancing of power plants' load curves. But off-peak electricity was not yet easily saleable since refrigerators and hot water heaters, which are also operated during the night and therefore consume off-peak electricity, were still poorly engineered and hardly affordable before World War II. ${ }^{21}$ But in the early years of the Nazi period, general promotion was expanded in another direction, namely electric cooking, popularized with means such as the cookbook Das elektrische Kochen ('Electric cooking'), which first appeared in 1936 and is still published today, meanwhile in its $53^{\text {rd }}$ edition. In 1938 , a non-linear rate system permitted an increase in electricity sales while entailing an automatic cost reduction for consumers. ${ }^{22}$

It was only during World War II that the advertising efforts were cut back dramatically: Trainings were offered only in exchange for food stamps and housewives were taught preferably at home. ${ }^{23}$ Appliances were advertised according to the logic of war. The conserving characteristics of refrigerators should "fight the spoilage of food", as the most important slogan pronounced, and electrical stoves were supposed to help saving solid fuels to the benefit of Germany's autarky. ${ }^{24}$

All advertising efforts of energy suppliers notwithstanding, the electrification of German households was not a smooth story of success. Especially the relatively high costs for power connections and electricity as well as consumers' skepticism hampered the comprehensive introduction of electricity before 1945 .

\section{"We Want to live electrically!": Promoting Electricity after 1945}

The transition to an affluent high-energy society in West Germany gained momentum after a period of energy scarcity after World War II. First of all, in 1945, energy saving became an important issue when the Allied Control Council passed Law No. 7, which determined the rationing of electricity

21 | Weltmann: “Elektrizitätswerbung in den Zwanziger Jahren”, 54.

22 | Döring: “Elektrizitätswerbung im 20. Jahrhundert”, 102.

23 | Krause: "Hausfrauenwerbung in Berlin”, 112.

24 | Döring: “Elektrizitätswerbung im 20. Jahrhundert”, 102. 
and gas due to the lack of coal and other fuels. ${ }^{25}$ Indeed, from late 1946 till late 1948, energy production had to be cut back even more than during World War II. The law designated the amount of domestic electricity consumption considered acceptable, overconsumption was fined and the use of electricity for heating as well as for lighting shop windows and advertisements was banned.

Berlin's first information centre and training kitchen already reopened shortly after the end of the war in 1946, teaching consumers about appropriate energy consumption in times of limited electricity supply. ${ }^{26}$ Hence, electricity companies did not advertise more, but less consumption until 1949, when the Federal Republic of Germany was founded and Bewag's most important power plant at that time, the power plant West, restarted. ${ }^{27}$

But as early as 1947, the Bewag used promotional cars even though Berlin was still in ruins. ${ }^{28}$ Moreover, electricity companies already tried to catch a glimpse of their future. For example, in 1948, Hans Saran, a pioneer of German electricity advertising, made it clear that

"the electricity rationing, introduced by the occupying powers, still imposes restrictions on electricity consumers. But domestic appliances, especially electric stoves, are, after the currency reform and the end of rationing measures, available again today. Cooking classes and demonstrations have to be introduced again to teach housewives how to make advantageous use of ration cards. ${ }^{29}$

25 | Cf. Allied Secretariat, ed.: "Law No. 7. Rationing of Electricity and Gas", in: Official Gazette of the Control Council for Germany 2 (30.11.1945), 32.

26 | Bewag: Beratungsstelle Steglitz am 12.11 .1955 wieder eröffnet, 15.11.1955, 5/52, Bewag-Archiv/Vattenfall Berlin. Although the Steglitz information centre was already provisionally reopened in 1946, its formal opening was only celebrated in 1955.

27 | Cf. footnote 16.

28 | Illustrations "Bewag-Werbung", 1946; "Elektro-Material Transport-Wagen", 1950, Bewag-Archiv/Vattenfall Berlin.

29 | Qtd. in Hanno Trurnit: Geschichte(n) hinterm Zähler. Die Beziehungen zwischen Energieversorgern und ihren Kunden. München: Trurnit \& Partner, 1996, 142-43. 
As soon as the rationing of electricity had come to an end in 1948 , utility companies aimed at broadening the market potential of domestic electricity consumption by promoting its use for more domestic activities such as heating water and space according to the slogan "Take advantage of electricity!" Moreover, architects and landlords became a new target group since old buildings had to be renovated and new homes were supposed to be completely electrified.

But for the post-war generation, thrift was still the first priority and consumers had to be convinced to invest in electric appliances for their homes. Therefore, Bewag emphasized that 'electric' has nothing to do with luxury. To give something electrical as a present will be rewarded. Electric appliances save time, money and work." ${ }^{30}$ Energy suppliers soon intensified their advertising efforts in order to promote electricity for every consumer and boost its demand. In general, the advertising efforts of utility companies after the rationing of electricity had ended were built on strategies which had already been known before World War II. Earlier discussions about the rationalization of the domestic workplace and the kitchen in the interwar period had created desires for domestic appliances that embodied contemporary modern lifestyle concepts and cultural notions, even though most consumers could not yet afford them.

The first German postwar magazine for electricity customers, Der Lichtblick ('The Ray of Light'), was published by Bewag in 1950 and their fourth information center and training kitchen was inaugurated in the same year in Berlin's Gesundbrunnen locality. ${ }^{31}$ For the Bewag, it was "an especially noble task to advise and educate our customers and thereby resume our promotional activities." 32 A lot of creative effort was put into the decoration of the window displays of Bewag's information centers. Rhyming slogans were popular as well as comparisons between the dirty and exhausting 'old times' and the modern, convenient and electrified 1950s. In advertisements, the housewives' 'revolution' was shown and their slogan seemed to express the claim of every consumer in the 1950s: "We want to live electrically!" (Fig. 1). Moreover, the Bewag was "happy that

30 | Der Lichtblick. Mitteilungen der Bewag 2 (1950), n.p.

31 The topic of the first course was how to cook fish and a cake at the same time. Cf.: "Schmeckt's bei der Bewag?", in: Der Tag 61 (12.03.1950), n.p.

32 | Betr.: Werbemaßnahmen und Werbeeinrichtungen, 1950, 5/52, Bewag-Archiv/Vattenfall Berlin. 
posters shine from every advertising pillar, which assure us that electricity is available to us in any amount, at any time of the day."33 As Heike Weber wrote, advertisements in the course of the $20^{\text {th }}$ century aimed less and less at mediating the understanding of a technology, and instead shifted towards abstract characteristics and emotional as well as experiential values. ${ }^{34}$ In the case of electricity, the technological understanding was emphasized until World War II, whereas values such as modernity, freedom, leisure and progress were linked to electricity in advertisements during the $1950 \mathrm{~s}$ and 1960 s.

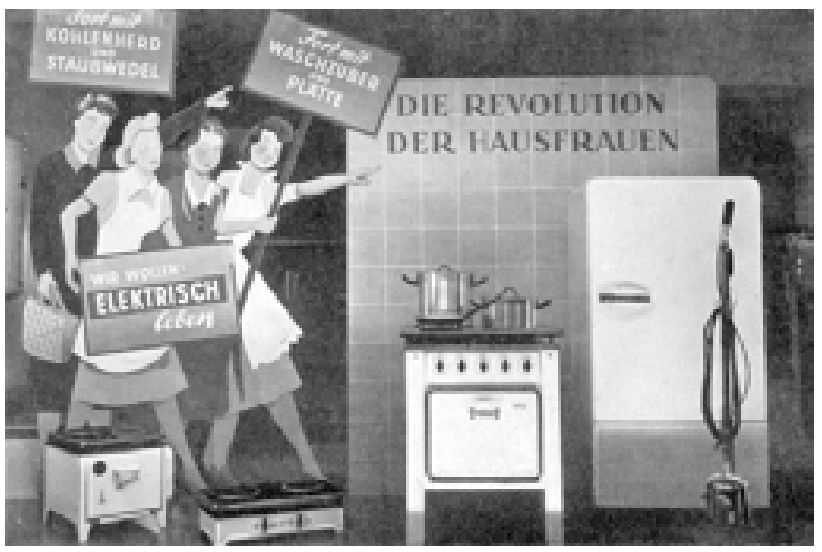

Figure 1: "Housewives' Revolution - We want to live electrically!" - Window Display of a Bewag Information Center, around 1955 .

But that electricity was available did not mean that it was affordable for everyone, even in Germany's 'economic miracle' era. Therefore, consumer campaigns were initiated by German politics, such as the refrigerator campaign in 1953, which was declared the 'year of the consumer', followed, in 1955 , by the campaign "Erhard helps the housewife", launched by the then minister of economic affairs, Ludwig Erhard. German politics unreservedly embraced the American model of the resource- and energyintensive Fordist consumption regime. Erhard proved to be one of the most fervent protagonists of a new social contract that was based on mass

33 | Der Lichtblick. Mitteilungen der Bewag 1 (1950), n.p.

34 | Weber: Das Versprechen mobiler Freiheit, 78. 
consumption and expected to provide the basis for a new German nation. Moreover, for political actors as well as electricity suppliers it was a foregone conclusion that 'promoting' electricity prices would "assure inexpensive electric energy for consumers which guarantees the best earnings for electric companies."35 Despite initial reluctance, utilities were eventually "willing [...] to make a contribution to the campaign. The electric industry supported the efforts of Minister Erhard" because they rediscovered private consumers and their energy consumption as a means to balance the daily load curves of power plants. ${ }^{36}$ Moreover, they recognized that low electricity prices were the best way to promote private energy consumption and therefore increase their sales. Upper Bavaria's electricity supplier IsarAmperwerke

"realized early that the opportunities of electricity supply in general and its own development are not to be found in high but in promotional prices. The result of this tariff policy did not disappoint our expectations. Today, the best guarantee for inexpensive electric energy for consumers is the fact that electricity has to be as cheap as possible to ensure the highest profits." 37

Following this reasoning, Bewag kept their electricity prices steady from 1938 even into the 1950s, although the costs for electricity production and distribution had risen. The efforts of energy suppliers and politics had the desired effects. In October 1955, the weekly paper Die Zeit stated: "Earlier than expected, it shows that Erhard's price-cutting campaign is successful. In the middle of an economic boom, these price deductions are relieving consumers' purses." 38

Not least because of this strategy, the electricity sector became a growth industry par excellence. The German Electrical and Electronic Manufacturers' Association (ZVEI) stated that further development hinged

35 | Isar-Amperwerke Aktiengesellschaft, ed.: Die Isar-Amperwerke. 50 Jahre im Dienste der oberbayrischen Stromversorgung. München: Isar-Amperwerke, 1958, 164-65.

36 | Vereinigung Deutscher Elektrizitätswerke an Staatssekretär Dr. Westrick BMWi: Betr.: Strompreissenkung, 15.12.1955, B102/770, Bundesarchiv Koblenz (BArch).

37 | Isar-Amperwerke: Die Isar-Amperwerke, 164-65.

38 | "Erhards Wunderkur hilft doch", in: Die Zeit, 13.10.1955. 
on the market for electric domestic appliances, which in turn depended on incomes and psychological factors. ${ }^{39}$ To persuade consumers of the advantages of electricity, the industry founded an advice center for electricity consumption (HEA) in 1952 which resumed the cooperative marketing of the electricity industry of the pre-war period by offering educational work about the characteristics of electric energy and its efficient handling. Public relations in the electricity industry were supposed to create trust and to improve the relationship between electricity companies and the public.

In general, the need for domestic electricity increased, but the industry was convinced that electricity had to be promoted nevertheless to expand sales. ${ }^{40}$ Therefore, in the business year of 1957/58, Bewag conducted 282 cooking courses with about 4,200 participants and almost 7,000 home visits..$^{41}$ In contrast to the late $19^{\text {th }}$ and first half of the $20^{\text {th }}$ century, when lighting and small appliances had been dominant, bigger appliances, such as stoves and refrigerators, were now the main focus of interest for consumers and producers. As electrification progressed, electricity networks expanded and newly built homes had more than one electric socket per room. As a result, while about 1,800,000 electric stoves had been in use in West Germany in 1949, this number tripled by 1960 , not least because of power companies' massive advertising efforts. ${ }^{42}$ Moreover, domestic electricity consumption in West Germany also more than tripled during the 1950s. ${ }^{43}$ These numbers illustrate the emerging establishment of a high-energy mentality in Germany during the 1950 s. This development was possible not least because discourses on modernity, prosperity and progress from the pre-war period were revived during the era of reconstruction and linked to the consumption of electricity. Whereas the production and distribution of domestic appliances had been supposed to compensate times of low load in the early $20^{\text {th }}$ century, utilities aimed

39 | Uwe Jönck: Die Entwicklung des Stromverbrauchs in der Bundesrepublik Deutschland bis zum Jahre 1970. Forschungsberichte des Landes NordrheinWestfalen, Köln: Westdeutscher Verlag, 1963, 33-35.

40| "Werbung - eine ethische Aufgabe”, in: Elektrizitätswirtschaft 54:21 (1955), 753-54.

41 | Krause: “Hausfrauenwerbung in Berlin”, 113.

42 | Friedrich Bieling/Paul Scholl: Elektrogeräte für den Haushalt. Ihre Entwicklung im Hause Siemens. Berlin: Siemens, 1966, 9-13.

43 | Jönck: Die Entwicklung des Stromverbrauchs, 77-78. 
at an overall increase of electricity demand during the 1950 . ${ }^{44}$ Massive advertising efforts for electricity and domestic appliances were supposed to transform electric energy into a cheap mass product and thus promote the boundless consumption of electric energy. For consumers, the 1950 os were therefore a crucial decade for the development of long-lasting convictions and consumption patterns. One example of a successful advertising campaign involving objects is the renting of electric stoves by Bewag.

\section{"Elektromiet": Bewag's Stove Rental}

This campaign had been launched in 1934 on the occasion of Bewag's $50^{\text {th }}$ anniversary as an ingenious alternative to Bewag's installment scheme "Elektrissima". Since installment schemes were not particularly popular with consumers who worried about long-term risks and increased costs, Bewag stepped up their advertising efforts by renting out stoves. Whereas the renting of hot water heaters had been successful already in the 1930s, Bewag's stove rental became popular in the early 1950s during a literal 'consumption wave' fostered by industry and politics.

In 1950 and 1951, $35^{\circ}$ electric stoves were given free of charge to sales representatives and employees in West Berlin whose stoves had been destroyed during World War II to "support an increase in electricity sales." 45 The appliance manufacturers AEG and Grätz collaborated with Berlin's utility in providing the stoves. This sparked massive protests. Newspapers indignantly wrote: "Bewag gives away stoves for free - with 'our money'!" 46 and even Berlin's municipality was concerned, but this problem was overcome with the reference to labor law-related claims. ${ }^{47}$ Bewag referred to the workers' right to receive benefits from their employers.

44 | Heinz Weidauer: “Stromabsatzwerbung”, in: Elektrizität 4:8 (1954), 231.

45 | Betr.: Elektroherdaktion. 20.06.1951, 5/52, Bewag-Archiv/Vattenfall Berlin; Vorstandsvorlage. Betr.: Kostenlose Überlassung von Elektroherden an Bewag-Angehörige. 05.09.1951, 5/52, Bewag-Archiv/Vattenfall Berlin.

46 | "Bewag verschenkt Elektroherde. Für “unser Geld'!”, in: Der Tagesspiegel, 15.06.1952.

47 | An die Mitglieder des Abgeordnetenhauses. Schenkungen der Bewag?, 10.07.1952, 5/52, Bewag-Archiv/Vattenfall Berlin. 
When Bewag expanded their campaign in 1953 , anyone could rent a stove, including electric circuits, pots and pans, but no longer for free. $4^{8}$ Renters had to pay 3 Deutsche Mark per month, which was only about twice as much as the hourly wage of an industrial worker. ${ }^{49}$ The campaign was advertised by 100,000 brochures, which were distributed by installers, specialized tradespeople and Bewag's information centers. An annual lease of 3,000 stoves was considered possible. But Berlin's electricity supplier was convinced that renters had to be supervised throughout the introduction to electric cooking: "In the case of dissatisfaction due to the incorrect handling of the stove, this discontent could be stirred up by competitors and the renter would terminate the rental agreement. Therefore it is necessary to arrange professional service at home with one 'lady' per household." ${ }^{\circ}$ Eventually, Bewag considered their renting campaign

"one of the most successful advertising efforts. Not only does the higher electricity consumption of a household equipped with such a stove contribute to the economic improvement of our company. The stove is also an incentive for the employee's relatives and friends to buy a stove themselves because they get to know the true advantages of an electric stove in the private household. ${ }^{51}$

The examples of Bewag's stove rental as well as their cooking courses show that advertising after the currency reform concentrated on bigger appliances such as electrical stoves. One reason was that a lot of households would not abandon their coal fire stoves which heated their kitchens unless they had been convinced of the benefits of an electric stove. Gradually, fridges also received increasing attention during the 1950 s. While in 1950 , only 4 percent of German households kept their food in an electrical fridge, ten years later

48 | Lieferschein für Materialbezug an Lager Schöneberg, 27.07.1966, 5/52, Bewag-Archiv/Vattenfall Berlin.

49 | Ludwig Erhard: Wohlstand für Alle. Düsseldorf: Econ, 1957, 107.

50 | Betriff: Herd- und Speicher-Mietaktion, 24.06.1953, 4-5, 5/52, BewagArchiv/Vattenfall Berlin.

$\mathbf{5 1}$ | Vorstandsvorlage. Betr.: Kostenlose Überlassung von Elektroherden an Bewag-Angehörige, Bewag-Archiv/Vattenfall Berlin. 
this figure had already reached 40 percent. ${ }^{52}$ But first and foremost, this development was the result of consumer campaigns initiated by German economic politics to boost private consumption during the 1950s, e.g. with the help of installment rates and price cuts. At the same time, refrigerators served the interest of utilities in a rising electricity demand during daytime and nighttime hours, but while politics took over the task of promoting refrigerators, utilities such as Bewag continued to promote electrical stoves.53 In fact, the strategies of politics and the electricity industry complemented each other to boost private consumption.

The strategies pursued by Bewag were exemplary for the 'economic miracle' period in Germany. Their advertising efforts concentrated on "a larger increase in sales, but preferably during certain hours; a differentiated price structure and its promotional effects; offering an incentive for consumers not by exhibiting electricity itself but appliances; making it easier to tackle the problem of costs; cooperating with appliance manufacturers" 54 , as an engineer summed it up in 1954.

Until the 1960 s, the general electricity euphoria continued and even expanded in the context of the popularization of nuclear energy. Decreasing electricity prices, a wider variety of domestic appliances, increasing income, the rise in women's employment and more living space per person favored this development. By 1960, even electric heating became more and more popular, not least because off-peak electricity got even cheaper. Since more and more households came closer to the ideal of the all-electric household, the demand for domestic electricity increased dramatically. To be modern meant to consume more energy. The need to save energy was - if at all remembered as a characteristic of a past and premodern era, characterized by deprivation.

52 | Ricarda Haase: “Das bisschen Haushalt ...”? Zur Geschichte der Technisierung und Rationalisierung der Hausarbeit. Stuttgart: Museum für Volkskultur in Württemberg, 1992, 24.

53 | Hösel: Vermerk. Betr.: Konsumfinanzierung von langfristigen Gebrauchsgüter, 14.04.1953, B102/35963, BArch.

54 | Weidauer: “Stromabsatzwerbung”, 232. 


\section{The 1960s: Aiming at the All-Electric Household}

At the end of the 1950s when electricity sold effortlessly, the electricity industry specialized in what they called "accompanying advice" and Bewag's promotion became more restrained. The electricity boom created new professional groups and fields, such as (female) electricity advisers for training kitchens and engineers who worked for electricity companies, supervising "customers in all aspects of electricity use in households, agriculture and trade." 55 Bewag trained their employees, especially those in field service, in special courses since they embodied the exemplary electricity user the company had in mind.${ }^{56}$ However, appliance manufacturers began to promote their products on their own since the competition within their sector became stronger.

But the advertising strategies of appliance and electricity producers still strongly resembled each other. Both aimed at the all-electric household, recognizing that they "approach electricity advertising carefully, maybe sometimes even too carefully and humbly. Only now we propagate the allelectric supply including space heating." 57 The serial production of electric appliances had gained momentum during the 1950 s and their mass consumption was supposed to compensate for times of low load. Electricity had become a cheap mass product, which in turn stimulated appliance sales..$^{8}$ By offering electric heating, the industry aimed at increasing the peak load of power plants which provided an argument for the construction of new power plants, since West Germany's power plant capacities were as yet sufficient for an all-electric nation.59 "You do not heat, you make yourself at home" was the slogan of a large advertising campaign for nightstorage heaters with reduced electricity rates in $1962 .{ }^{60}$

55 | RWE: “Stellenanzeige Elektro-Ing.“, in: Elektrizität 23:2 (1973), A14.

56 | Johann Dittel: “Die Bewag-Schule”, in: Elektrizität 7:7 (1957), 179.

57 | “Auf dem Weg zum vollelektrischen Haushalt”, in: Elektrizität 13:12 (1963), 351.

58 | Weidauer: "Stromabsatzwerbung", 231.

59 | Wolfgang Zängl: Deutschlands Strom. Die Politik der Elektrifizierung von 1866 bis heute. Frankfurt/Main: Campus, 1989, 246.

60 | Berliner Kraft- und Licht (Bewag)-Aktiengesellschaft, ed.: 100 Jahre Strom für Berlin. Ein Streifzug durch unsere Geschichte in Wort und Bild, 1884-1984. Berlin: Bewag, 1984, n.p. 
But while electricity became an affordable mass product, the anticonsumption and environmental movement of the 1960 s emerged. Consumers began to worry about their health and deteriorating living conditions for them and their children. ${ }^{61}$ Books like Rachel Carson's Silent Spring $^{62}$ inspired this movement in 1962 and ten years later The Limits to $\mathrm{Growth}^{6}{ }_{3}$ reflected widespread social concern. Environmentalists even succeeded in delaying plans to expand power plants. ${ }^{64}$ But consumers who began to critically assess their energy consumption in the 1960 s were told by electricity advisers to reconsider their concerns in favor of electricity sales: "Urban customers enquire about the increased electricity consumption of quick freezing even smaller amounts of food. [...] Our standard answer was that those watt-hours are cheaper than the price of a frozen meal or cake." ${ }^{25}$

Furthermore, beginning with the 1966/67 recession in West Germany, power companies and appliance manufacturers were confronted with increasing market saturation. Indeed, most households were already equipped with white goods such as washing machines, electric stoves and fridges. Energy suppliers had to develop new strategies to tap into new markets and encourage even more energy consumption. One German electricity supplier from Nuremberg even awarded a medal for "exemplary electric facilities" - from a power company's viewpoint - to eight households in their service area. ${ }^{66}$

Of major importance were the predictions of the electric industry, based on energy consumption statistics of the early 1960 s, of an annual increase in private energy consumption of seven percent, blatantly negating the bad economic situation in the recession. According to them, an "energy

61 | Cf. e.g. "Wir sind dabei, den Planeten Erde zu ermorden“, in: Der Spiegel 48, 24.11.1969.

62 | Rachel Carson: Silent Spring. Greenwich, CT: Fawcett, 1962.

63 | Dennis L. Meadows/Donella Meadows/Jørgen Randers/William W. Behrens: The Limits to Growth. A Report for the Club of Rome's Project on the Predicament of Mankind. New York: Universe Books, 1972.

64 | "Kraftwerke. Gedanken an Strom”, in: Der Spiegel 33, 07.08.1972, 56-57.

65 | Gertrud Iven: "Antwort des Kunden auf unsere Werbung fürs Eingefrieren”, in: Elektrizität 18:7 (1968), 185.

66 | "Gold für vorbildliche elektrische Ausstattung", in: Elektrizität 23:8 (1973), 256. 
gap" had to be feared which would impact freezers, radios, TVs, heaters and so on. In advertisements, utility companies reminded their customers that new power plants and supply lines were necessary "to make sure you will always have electricity!" 67 The German weekly news magazine Der Spiegel blamed power companies for having double standards. On the surface, they acknowledged the looming environmental crisis. But at the same time, they created fears of a gap in supplies among consumers while positioning themselves as reliable and trustworthy energy suppliers. ${ }^{68}$ Actually, the predictions were excessive, but utility companies nevertheless managed to justify the construction of new power plants. Therefore, it became clear that despite all concerns, West German households were strongly integrated in large technical systems such as the power network, depending on high energy consumption and well-equipped kitchens. Despite some consumers' concern and due to massive customer advice, the equipment of households with electric appliances increased rapidly until 1971. While 42 out of 100 households had owned an electric stove in 1961 and 47 had owned a refrigerator, these numbers rose to 64 electric stoves and 88 refrigerators in $1971 .{ }^{69}$

\section{New Challenges: Changing Strategies of Utility Companies after 1973}

The electricity industry was able to promote an increase in sales despite growing ecological awareness during the 1960s, but the situation changed fundamentally in the following decade. Beginning with the 1970s, ecology and energy became controversial topics for politics, the industry and consumers in most Western, industrialized nations. ${ }^{70}$ The positive connotation of electricity as a modern, progressive and cheap form of energy was replaced by an ecologically harmful, expensive and, in the case of nuclear energy, health-threatening image. These developments led to widespread public opposition against the waste of resources and

67 | "Kraftwerke. Gedanken an Strom", 56-57.

68 | "Kraftwerke. Gedanken an Strom", 56-57.

69 | Berliner Kraft- und Licht (Bewag)-Aktiengesellschaft: 100 Jahre Strom für Berlin, n.p.

$\mathbf{7 0}$ | Cf. the example of France in Yves Bouvier's contribution in this volume. 
environmental pollution associated with electricity production and consumption. Electricity suppliers were increasingly criticized for their coal-fired power stations without filters, which caused air pollution and forest decline, and nuclear power plants became more controversial. Ecological concerns arose which concentrated not on the consumption, but on the production of electricity first. Bewag, for instance, reacted by beginning to inform interested consumers in 1972 about the air pollution control of their power plants.

At the same time, electricity had become an essential feature of consumers' lifestyles, but its consumption had not been critically reflected since energy suppliers and politics had promoted its unlimited consumption in the 1950 s and 1960 s. Nevertheless, consumers were aware of the tense situation in the early 1970s:

"Electricity has become indispensable for our everyday life. But the more natural something becomes - such as electricity - the less we think about it, its origin, its future supply and its consumption. It is handled too thoughtlessly. But it is worthwhile thinking about efficient consumption, since reserves will last for a limited time only. This concerns every electricity consumer! A process of rethinking is necessary. [...] But it is also obvious that we cannot abandon certain standards of supply and comfort." ${ }^{71}$

Indeed, starting in 1972, electricity suppliers began to realize that consumers might soon reflect about their electricity consumption because of an impending resource scarcity. Moreover, the first oil crisis in the early 1970 s hit Bewag hard and "rational energy use" became an abiding topic of customer advice, using the slogan "Use electricity - do not waste it". The company called for an end to excessive electricity waste in private households and a reduction of pollution on their own part. In general, electricity companies recognized that they had neglected their public presentation and that it was hard to convince customers to opt for a judicious use of energy: "We have to assume that the advertising campaign

71 Irmgard von Meibom: "Der Energieverbrauch aus der Sicht des Verbrauchers", in: Elektrizität 23:12 (1973), 385-86. 
with the slogan 'Do it right' is characterized by a protracted and complicated process of rethinking." 72

Another incentive to advise electricity customers resulted from public protests against power plant constructions. The industry, which aimed at a further expansion in sales, assumed that the power plant opponents were poorly informed: "Consumers have to be more aware of their electricity consumption which has to be demonstrated in a way that is clear and easy to understand. [...] To provide an appropriate transition from the image of electricity as a bargain to a new campaign, the well-known symbols - a friendly socket and electricity symbol - should continue to be used."73 Image advertising was the most important means for electricity companies to retain and extend markets. But the 1973 oil crisis intensified the discussions about thoughtless energy consumption. Slogans like "Electricity makes everything easy and pleasant and it's cheap too!" were soon out of date.

In the 1970s, utility companies took on a paradoxical role. On the one hand, they felt obliged to guarantee the future supply of more and more electricity and on the other hand, they were held responsible for environmental problems and climate change. ${ }^{74}$ Because of increasing electricity prices and large profits, they had to face political and public criticism and were expected to take on social responsibility. They experienced a credibility dilemma: How could they recommend energysaving while being dependent on high electricity sales? In fact, there was an argument for power plant operators to promote energy saving appliances since they were supposed to prevent the construction of new power plants which would have caused high investment costs.

But the public was becoming increasingly aware of its energy consumption and the electric industry's former strategy of advising, educating and marketing to encourage electricity consumption had to be turned into the cultivation of a new image. It seemed to be the right moment to develop new advertising strategies. Acceptance and sympathy for the production of electricity had to be generated and information centers such as Bewag's "Elektrotip" opening in Berlin in 1970 became energy-

72 | Wolfgang Dotzenrath: "Sinnvolle Elektrizitätsanwendung als Beratungsaufgabe der HEA”, in: Elektrizität 23:5 (1973), 108.

73 | Dotzenrath: "Sinnvolle Elektrizitätsanwendung“, 108.

74 | Weber: “Elektrizitätswerbung zwischen Markt und Ökologie”, 319. 
saving advice centers..$^{75}$ The most popular form of advice were brochures containing instructions about the purchase of the right appliances and energy saving. Electricity suppliers published those brochures in order to educate consumers and, at the same time, to promote the industry's responsibility by showing power plants or domestic appliances in settings showing customers and natural environments.

In general, electricity advertising decreased after the 1973 oil crisis and the minister for economic affairs, Hans Friderichs, even recommended being "more careful" 76 because of the strong public opposition against nuclear power. The remaining advertising efforts of utility companies continued to concentrate on brochures and advice in the 1980s (Fig. 2). Besides that, Bewag offered mobile information and rented out devices called "energy saving detectives", which helped consumers to check the energy consumption of their appliances.
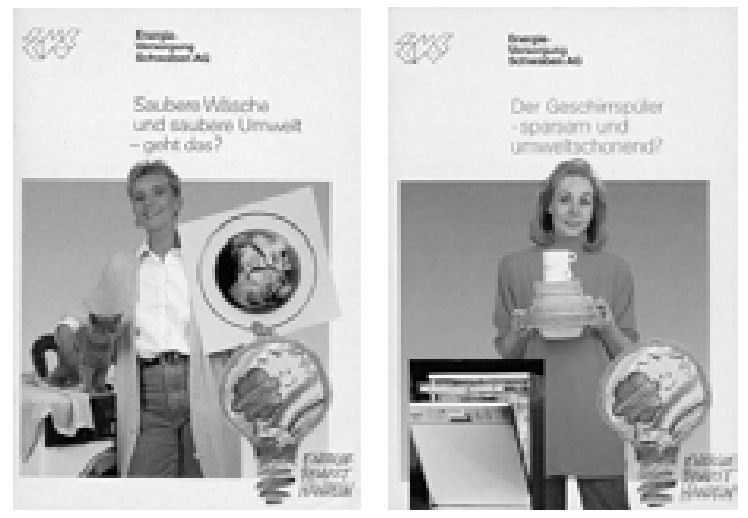

Figure 2 and 3: "Clean Laundry and Clean Environment Is the Possible?" / "The Dishwasher - Economical and Environmentally Friendly?", Brochures, Energieversorgung Schwaben, around 1990.

While Bewag had celebrated "electric parties" during the German Industrial Exhibition in 1969, they opened an exhibition entitled "Energy

75 | “'Elektrotip’ nun auch in Berlin NW”, in: Spandauer Volksblatt, 05.11.1970, n.p.

76 | “Weniger Werbung für Strom”, in: Der Spiegel 33, 08.08.1977, n.p. 
from the Environment - Used for Electricity" after the second oil crisis ten years later, where energy-saving technologies, heat pumps, heat recovery systems and solar panels were shown. ${ }^{77}$ Street parties, painting and prize competitions were also supposed to increase customer loyalty after the crisis-ridden 1970 s. $^{78}$

Energy saving was elevated to a national virtue; even manufacturers apparently internalized the 'eco paradigm' during the 1980s. They committed themselves to produce more efficient appliances, which led to large savings in the energy consumption of the improved appliances ${ }^{79}$, but not of households in general. Nevertheless, 'eco'-efficiency and the closeness to nature were the most important advertising strategies for electricity suppliers and appliance manufacturers after 1973. For example, the AEG was the first company which advertised its household appliance branch as explicitly ecological. ${ }^{80}$ The advertising of efficiency and low electricity consumption became the most important selling and purchasing criterion in a highly competitive market. ${ }^{81}$ Apparently, those strategies were successful. In 1987, a psychologist explained that even after the nuclear accident in Chernobyl, electricity as a whole retained a good public image, with only nuclear power plants and energy acquiring a very poor reputation. This was, in his mind, due to the fact that the marketing campaigns of the electricity industry concentrated on confidence-building

77 | Berliner Kraft- und Licht (Bewag)-Aktiengesellschaft: 100 Jahre Strom für Berlin, n.p.

78 | Berliner Kraft- und Licht (Bewag)-Aktiengesellschaft: 100 Jahre Strom für Berlin, n.p.

79 | "Sprechzettel - Zur Einleitung der Besprechung am 24.01.1980 mit den Vertretern der Hausgerätehersteller über weitere Energiesparmöglichkeiten", 1980, B102/289597, BArch.

80 | Cf. e.g. "Natürlich AEG. Ratgeber umweltfreundliches Haushalten", 1990, I.2.060 P 1910, Firmenarchiv AEG-Telefunken, Stiftung Deutsches Technikmuseum Berlin (SDTB); cf. “Umweltbelastung abbauen. Spargeräte einbauen. Ausgewählte Einbaugeräte für die Küchenmodernisierung“, Januar 1994, I.2.060 P 1816, Firmenarchiv AEG-Telefunken, SDTB.

81 | Sylvia Wölfel: “Von der Werbung für Strom zur Werbung für Energieeffizienz. Umweltfreundliche Haushaltstechnik in der Bundesrepublik und der DDR", in: Theo Horstmann/Regina Weber, eds. "Hier wirkt Elektrizität". Werbung für Strom 1890 bis 2010. Essen: Klartext, 2010, 194. 
and reassurance, thus propagating a sense of responsibility and proximity to nature. Power plant operators even claimed that it was the general public and its demand for energy that should be blamed for the construction of nuclear power plants. ${ }^{82}$

\section{Conclusion}

Electricity companies contributed to the equipment of homes with energy consuming devices during the $20^{\text {th }}$ century and the development of German consumers' high-energy mentality since the 1950s. The foregoing analysis of electricity advertising is a contribution to the reconstruction of electricity-related discourses and has shown which image of consumers producers had in mind as well as the reasons and obstacles of electricity consumption.

At the turn of the $20^{\text {th }}$ century, customers had been concerned about electricity and energy-consuming appliances. They had feared security hazards, a lack of space, excessive operating and especially purchasing costs and had expected marginal benefits. Against these low expectations, Walther Rathenau claimed that electricity should no longer be considered a luxury commodity and that its use had to be "forced" on consumers in order to create a market. But with its gradual spread, consumers were in need of advice concerning the use of electricity as a new form of energy and utility companies acted as their assistants and teachers. In the first twenty years of the $20^{\text {th }}$ century, electricity was advertised as competing with petroleum, gas and coal, and presented as superior based on its cheap price and safety. During the 1920s, German electricity suppliers professionalized their advertising campaigns and in the subsequent early Nazi period they pursued marketing strategies that put appliances such as electric stoves center stage because they were supposed to save other fuels for Germany's autarky. ${ }^{8}$ During World War II and in the first post-war years, campaigns for the saving instead of the consumption of electricity were common.

In the early second half of the $20^{\text {th }}$ century, by means of campaigns such as the rental of stoves, Bewag employees acted as a modern,

82 | Gerhard Hunnius: "Das Bild der Stromwirtschaft in der Öffentlichkeit 1986/87", in: Elektrizitätswirtschaft 86:16/17 (1987), 727-32.

83 | Döring: “Elektrizitätswerbung im 20. Jahrhundert”, 96. 
progressive example for German consumers, even though the majority of West German homes were not yet equipped with an all-electric household. Electricity marketing experienced its successful peak in the 1950s, indicating the emergence of a high-energy mentality in Germany, although the origins of these promotional efforts date back to the beginning domestic mechanization before World War II. Power companies advertised by means of advising and educating consumers to popularize electricity in Germany. Due to their advertising efforts and supplemented by consumer campaigns of Germany's economic policy, the all-electric kitchen and a comprehensive democratization of electricity were achieved by the 1960 s.

But contradictions soon emerged in the context of growing ecological awareness. Regarded as a problem solver and infused with great utopian expectations since its introduction ${ }^{84}$, electricity became a problem itself. Following the 1973 and 1979 oil crises, growing private energy consumption was criticized and electricity companies had to re-shape their image according to new paradigms such as ecology and sustainability. They had to develop new advice and education strategies to reinterpret their main business - producing and selling electricity - as an act of ecological responsibility. Electric appliances as advertising material became much less important for electricity suppliers over the years and marketing cooperation between utilities and appliance manufacturers diminished significantly. But although they went their separate ways, their campaigns have remained similar. Private households were still important settings for advertising and since the early 1970s, ecological values and abstract energy consumption data have characterized the advertising for electricity.

Today, we have a fundamentally new situation. Electricity has become an everyday commodity and since the liberalization of the German electricity market in 1998, strong competition has emerged because areas of supply are no longer clearly divided. ${ }^{85}$ Due to the pressure of competition, utility companies have to position and profile themselves on the market with new and extraordinary advertising strategies.

In the first half of the $20^{\text {th }}$ century, it was the functional aspects of electricity such as its inexpensiveness and safeness that were the focus of electricity advertising. After World War II, emotional values such as

84 | Cf. e.g. Beate Binder: Elektrifizierung als Vision. Tübingen: Tübinger Vereinigung für Volkskunde, 1999.

85 | Weber: "Elektrizitätswerbung zwischen Markt und Ökologie“, 319. 
modernity and progress as well as benefits such as more leisure were promoted and related to electricity. Consumers' responsibility to save energy was not discussed among electricity companies during the $1950 \mathrm{~S}$ and 1960 s and therefore not mediated via their marketing strategies. New images and forms of advertising had been in focus of electricity advertising since the early 1970 s as a result of the oil crises and consumers' ecological awareness. An image of ecologically responsible energy suppliers and harmless electricity has been the most important motif of advertising campaigns for electricity since then, combined with the appeal to consume electricity sustainably.

This analysis of advertisements of electricity suppliers aims to contribute to the understanding of the fact that, despite the growing efficiency of appliances since the late 1970s, the total energy consumption of households has not decreased and electricity has retained a good public reputation despite its controversial role for the environment. Furthermore, this paper also shows that electricity advertising contributed to the fact that in the course of the $20^{\text {th }}$ century, but especially since the post-war era, German private households and domestic life have become inextricably linked to electricity, even though electricity production and consumption is meanwhile associated with environmental damage.

The foregoing analysis expects to broaden the view on the changing meanings of private energy consumption in the course of the $20^{\text {th }}$ century and especially after World War II by a study of changing electricity advertising, reflecting the transition to a high-energy society in Germany. For further studies, it would be worthwhile to closely examine electricity advertisements after 1990, in a united Germany, and to compare developments in Germany to electricity advertising in other countries.

\section{References}

\section{Primary Sources}

Bewag-Archiv/Vattenfall Berlin

5/52 Elektroherde, Geschichte und Entwicklung des E-Herdes, Broschüren, Preislisten, Herd-Aktion für Mitarbeiter

Bundesarchiv, Koblenz (BArch)

B 102 Bestand Bundesministerium für Wirtschaft 
Archiv der HEA, Berlin

Stiftung Deutsches Technikmuseum, Berlin

I.2.060 Firmenarchiv AEG-Telefunken

Der Lichtblick. Mitteilungen der Bewag, $195^{\circ}$

Der Spiegel, 1969, 1972, 1977

Der Tag, 1950

Der Tagesspiegel, $195^{2}$

Die Zeit, 1955

Elektrizität, 1954, 1957, 1959, 1963, 1968, 1973

Elektrizitätswirtschaft, 1955, 1987

Official Gazette of the Control Council for Germany, 1945

Spandauer Volksblatt, 1970

\section{Secondary Sources}

Barthes, Roland. Mythen des Alltags. Frankfurt/Main: Suhrkamp, 1964.

Berliner Kraft- und Licht (Bewag)-Aktiengesellschaft, ed. 100 Jahre Strom für Berlin. Ein Streifzug durch unsere Geschichte in Wort und Bild, 18841984. Berlin: Bewag, 1984.

Bieling, Friedrich/Scholl, Paul. Elektrogeräte für den Haushalt. Ihre Entwicklung im Hause Siemens. Berlin: Siemens, 1966.

Binder, Beate. Elektrifizierung als Vision. Tübingen: Tübinger Vereinigung für Volkskunde, 1999.

Carson, Rachel. Silent Spring. Greenwich, CT: Fawcett, 1962.

Döring, Peter/Weltmann, Christoph. “'Die Erweckung von Stromhunger’. Elektrizitätswerbung im 20. Jahrhundert”, in: Horst A. Wessel, ed. Das elektrische Jahrhundert. Essen: Klartext, 2002, 93-108.

Erhard, Ludwig. Wohlstand für Alle. Düsseldorf: Econ, 1957.

Gries, Rainer/Ilgen, Volker/Schindelbeck, Dirk, eds. “Einleitung. Kursorische Überlegungen zu einer Werbegeschichte als Mentalitätsgeschichte”, in: "Ins Gehirn der Masse kriechen!" Werbung und Mentalitätsgeschichte. Darmstadt: Wissenschaftliche Buchgesellschaft, 1995, 1-28.

Haase, Ricarda. "Das bisschen Haushalt ...?” Zur Geschichte der Technisierung und Rationalisierung der Hausarbeit. Stuttgart: Museum für Volkskultur in Württemberg, 1992.

Horstmann, Theo/Weber, Regina, eds. "Hier wirkt Elektrizität”. Werbung für Strom 1890 bis 2010. Essen: Klartext, 2010. 
Isar-Amperwerke Aktiengesellschaft, ed. Die Isar-Amperwerke. $50 \mathrm{Jahre} \mathrm{im}$ Dienste der oberbayrischen Stromversorgung. München: Isar-Amperwerke, 1958.

Jönck, Uwe. Die Entwicklung des Stromverbrauchs in der Bundesrepublik Deutschland bis zum Jahre 1970. Forschungsberichte des Landes NordrheinWestfalen. Köln: Westdeutscher Verlag, 1963.

Koch, Ludwig: "Die Haushaltsgeräte-Absatzpolitik in Elektrizitäts-Versorgungsunternehmen” (Unpublished Ph.D. diss., Ludwig-MaximiliansUniversität München, 1957).

Kocka, Jürgen. "Neue Energien im 19. Jahrhundert. Zur Sozialgeschichte der Elektrizitätswirtschaft”, in: Evelyn Gröbl-Steinbach, ed. Licht und Schatten. Dimensionen von Technik, Energie und Politik. Wien: Böhlau, 1990, 17-31.

Kracauer, Siegfried. “The Mass Ornament”, in: New German Critique 5 (Spring 1975), 67-76.

Meadows, Dennis L./Meadows, Donella/Randers, Jørgen/Behrens, William W. The Limits to Growth. A Report for the Club of Rome's Project on the Predicament of Mankind. New York: Universe Books, 1972.

Oldenziel, Ruth/de la Bruhèze, Adri Albert/de Wit, Onno. “Europe’s Mediation Junction. Technology and Consumer Society in the $20^{\text {th }}$ Century”, in: History and Technology 21:1 (2005), 107-39.

Pursell, Carroll. "Domesticating Modernity: The Electrical Association for Women, 1924-86”, in: The British Journal for the History of Science 32:1 (1999), 47-67.

Trurnit, Hanno. Geschichte(n) hinterm Zähler. Die Beziehungen zwischen Energieversorgern und ihren Kunden. München: Trurnit \& Partner, 1996. Weber, Heike. Das Versprechen mobiler Freiheit. Zur Kultur- und Technikgeschichte von Kofferradio, Walkman und Handy. Bielefeld: transcript, 2008.

Weber, Regina. "Elektrizitätswerbung zwischen Markt und Ökologie”, in: "Hier wirkt Elektrizität”. Werbung für Strom 1890 bis 2010. Essen: Klartext, 2010, 318-21.

Weltmann, Christoph. “Elektrizitätswerbung in den Zwanziger Jahren. Landwirte im Fokus und 'Elektrizität in jedem Gerät' - eine Werbemarke für Strom”, in: Theo Horstmann/Regina Weber, eds. "Hier wirkt Elektrizität”. Werbung für Strom 1890 bis 2010. Essen: Klartext, 2010, 4861. 
Willems, Herbert. Rahmen und Habitus. Zum theoretischen und methodischen Ansatz Erving Goffmans. Vergleiche, Anschlüsse und Anwendungen. Frankfurt/Main: Suhrkamp, 1997.

Wölfel, Sylvia. "Von der Werbung für Strom zur Werbung für Energieeffizienz. Umweltfreundliche Haushaltstechnik in der Bundesrepublik und der DDR", in: Theo Horstmann/Regina Weber, eds. "Hier wirkt Elektrizität”. Werbung für Strom 1890 bis 2010. Essen: Klartext, 2010, 192205.

Zängl, Wolfgang. Deutschlands Strom. Die Politik der Elektrifizierung von 1866 bis heute. Frankfurt/Main: Campus, 1989. 


\title{
Filming Electrical Consumption
}

\author{
EDF's Promotional Films (1946-2004)
}

Yves BouvieR

Energy consumption is a subject that closely blends the economic with the cultural sphere. ${ }^{1}$ Energy suppliers sell energy as a consumer good and households also consider energy as a good when bills arrive. But suppliers, when they aim to sell energy, are using all the symbols of this good. Energy consumption and meanings of energy are socially constructed and energy suppliers are players in this construction process. In shaping the image of energy, the suppliers envision the behavior of consumers. Thus, studying advertising and more particularly advertising of energy suppliers, is a good way to deconstruct the cultural representations associated with energy and analyze how these representations emerged within the scope of business strategies. In advertising, energy consumers are present as projected consumers imagined by the energy supplier. ${ }^{2}$ Analyzing advertising needs to refer to media and cultural studies as well as business history.

This article aims to explore promotional films as cultural representations of energy and energy consumption that have been produced on behalf of the French energy supplier Électricité de France (EDF). Within the framework of this article, I will interpret promotional films of the French national

1 | I wish to thank Karin Zachmann and Nina Möllers for their useful comments and Scott Brown for his help with the translation.

2 | Nelly Oudshoorn/Trevor Pinch: "How Users and Non-Users Matter”, in: Nelly Oudshoorn/Trevor Pinch, eds.: How Users Matter. The Co-Construction of Users and Technology. Cambridge, MA, MIT Press, 2003, 1-25; Ruth Oldenziel/Karin Zachmann: "Kitchen as Technology and Politics", in: Ruth Oldenziel/Karin Zachmann, eds. Cold War Kitchen. Americanization, Technology and European Users. Cambridge, MA, MIT Press, 2009, 13. 
electric company from its creation in 1946 to the beginning of 2000 s. The objective is to explore how the cultural representations of energy have been employed within the business strategies of a public company and which kinds of relationship between consumers and energy are staged in these promotional films. Meanings of energy consumption and uses of symbols have changed over the last six decades, especially considering the many different historical contexts since the end of WWII: energy shortage, affluent society, energy crisis, nuclear turn, the emergence of renewable energies and many more. How does EDF present electrical consumption in these promotional films and what are the relationships between the objects, the consumers and the firm staged in them? Symbols used in these advertisements need to be questioned as ideologies and modern myths. But it is also necessary to consider the technical and economic basis of these representations in order to go beyond the surface of the films and to detect the deeper meanings of these cultural productions. In his study on General Electric's photographic collection, David Nye writes that "the corporation's creation and control of such materials is a metaphor for its cultural hegemony." 3 The same statement could be applied for EDF and its promotional films as the electricity supplier produces not just energy but also culture.

EDF was created on April $8^{\text {th }}, 1946$ by the nationalization of all French firms of the energy sector (electricity, gas, coal). The idea of nationalization had already been present in debates during the mid-1930s. ${ }^{4}$ During WWII, in March 1944, the National Council of the Resistance adopted a program for the years after the end of the war, which included the nationalization of energy. Occasionally, the French considered EDF as a branch of government but it was a public firm with national goals: providing the perfect grid and low prices for electricity. These company tenets strongly determined its image and its strategy until the end of the 1980s. The national scale is the relevant level for an understanding of EDF's behavior. In other words, EDF's strategies aimed at national growth and modernization of national infrastructures. This is why EDF was the leader of the French electrical

3 | David E. Nye: Image Worlds. Corporate Identities at General Electric, 18901930. Cambridge, MA : MIT Press, 1985, 3.

4 | Patrick Fridenson: "Réflexions sur les étapes de la nationalisation de l'électricité", in: AHEF. La nationalisation de l'électricité en France. Nécessité technique ou logique politique? Paris: PUF, 1996, 383. 
sector, from industry to private homes. The Europeanization of energy markets and the decline of state-owned companies changed this context in the beginning of the 1990s. In August 2004 then, EDF was transformed into a stock corporation, but the state still owns about 85 percent of its shares.

The corpus I am researching is composed of 62 promotional films made for cinema or TV between 1955 and 2004. In France, TV advertising began in 1968. But until 2004, most of EDF's promotional films broadcast on TV were also aired on the big cinema screen before feature films. This corpus includes only those promotional films shorter than 2 minutes, but not the various movies produced during the 1950 s and the 1960 s which are between 5 and 50 minutes in length and deal with EDF's large projects like the building of dams in the Alps or the first nuclear power plant in Chinon in 1963. The choice to focus my research on these shorter advertisements is justified by my intention to put the focus on the socio-cultural stereotypes employed in the films. Advertisements concentrate on stereotypes to effect their meaning more efficiently. Not all the promotional films are relevant to my viewpoint on electricity consumption because some of the films show infrastructure or deal with the open offer of shares at the end of the period in question. I select only the advertisements on electricity consumption which constitute 41 promotional films. These films are in the database of the EDF Médiathèque and a few papers are to be found in EDF's Center of Historical Archives in Blois. There are also some EDF publications such as Contacts, which became La vie électrique, then Vivre EDF and which has been the internal publication of the firm since the mid-1950s.

My paper is organized into three parts, defined by three periods:

- 1955-1973: EDF promoted electricity by showing the wide range of possible applications. Eleven films out of 13 made during this period can be attributed to this promotional topic.

- 1974-1992: EDF developed the discourse on energy-saving by showing consumers' behavior. Ten promotional films out of 14 that were produced in this period are relevant.

- 1992-2004: EDF realized films dealing with a "new electrical comfort" by restoring the objects as cultural signs. This corpus contains 14 relevant films out of 35 during this period. 


\section{The Magical Atmosphere of Electrical Appliances, 1955-1973}

The first period was a time of economic growth and the building of an affluent society in France. The objects of consumer culture were becoming more common, but still the 'gadgetization' of the kitchen did not occur before the beginning of the 1960 s. The consumption society made these objects sacred, giving them a cultural value which exceeds their use value. Anthropological studies of modern societies, such as Jean Baudrillard's critiques of contemporary civilization, analyzed the processes of the creation of modern myths..$^{5}$ Objects and mass media are, not surprisingly, the two main fields of reference for him. Baudrillard analyzed how the objects changed the social relationships, the balance of the society and the cultural scheme of individuals. In this framework, advertisements shape the discourse and the image of modernity. For Roland Barthes particularly, some objects (a car, a toy, a plastic artifact...) are the new myths of modern society. ${ }^{6}$ He defines myth as a system of communication which opens the path to semiological studies. The idea of modern artifacts as systems of communication means that objects are "vehicles of meaning."7

EDF did not develop a real communication policy until the mid-1950s. In 1946, and for its first decade, the objectives of EDF were to complete the electrification of the country and to harmonize existing electrical networks. Power cuts were still used until 1950 because of the insufficient electricity production in France. More than 1,000 private companies had been nationalized but they had not adopted the same technology (voltage for example) or the same prices. Of course, all the cities and most of the rural villages had electricity before WWII, but deep regional inequalities remained. In Brittany, for example, 23 percent of homes did not yet have

5 | Jean Baudrillard: Le système des objets. Paris: Gallimard, 1968, 288; La société de consommation. Ses mythes. Ses structures. Paris: Denoël, 1970, 318.

6 | Roland Barthes: Mythologies. Paris: Seuil, 1970, 233. On Baudrillard and Barthes and their links with the electrical households appliances, see Claire Leymonerie: "Des formes à consommer. Pensées et pratiques du design industriel en France (1945-1980)" (Unpublished Ph.D. diss., EHESS-Université Toulouse II, 2010).

7 | Roland Barthes: "Semantics of the Object", in: The Semiotic Challenge. Berkeley: University of California Press, 1994, 179-190, 293. 
electricity in 1954. Thus, the focus of EDF's business strategy was not toward the increase of consumption via intensified advertising (even if urban consumers liked the advertisements), the priority was instead on the installation of a coherent national network. It took 15 years to achieve this mission by the construction of new hydroelectric production units (factories of Malgovert and Brévières for the use of Tignes dam water for example $e^{8}$ and new coal and fuel power stations. At the same time, the standards of the transport network were defined by a $220 \mathrm{kV}$ grid which took the place of the former 110 and $120 \mathrm{kV}$ networks. These achievements attracted the attention of the media. EDF organized a press service in 1946 to relay the announcements of the inaugural ceremonies of various power stations. However, it was only in 1955 that a real communication structure was created, the "communication cell", led by Paul Auriol, son of the President of the Fourth Republic at that time.

The first promotional film to be analyzed is a cartoon entitled The Electricity Fairy (1955) in which a small woman waves her magic wand to install or transform old objects into electrical objects (Fig. 1). In her house, each room has an electrical object: lamp and radio for the living-room, refrigerator and oven for the kitchen, washing machine for the laundry and water heater for the bathroom.

The appearance of a household fairy, a perfect maid for all manual work, is a transformation of the old electricity fairy which was a well-known representation for the new energy at the end of the $19^{\text {th }}$ century. In France, the electricity fairy was a political icon, linked with the ideology of social progress at the beginning of the Third Republic. The keywords of this cartoon from the 1950 s are "cleanness, comfort and leisure".

8 | The Tignes dam is a good example of the political context of these years: The old Tignes village was destroyed for the building of the dam, in the name of the general interest. Newspapers, newsmagazines, cinema newsreel and TV related the history of this village. In a way, EDF experimented with the power of the mass media for the first time during the building of the Tignes dam. Denis Varaschin: Tignes, la naissance d'un géant. Arras: Artois Presses Université, 2001, 197207; Virginie Bodon: La modernité au village. Tignes, Savines, Ubaye... La submersion de communes rurales au nom de l'intérêt général. 1920-1970. Grenoble: Presses universitaires de Grenoble, 2003, 132-137. 


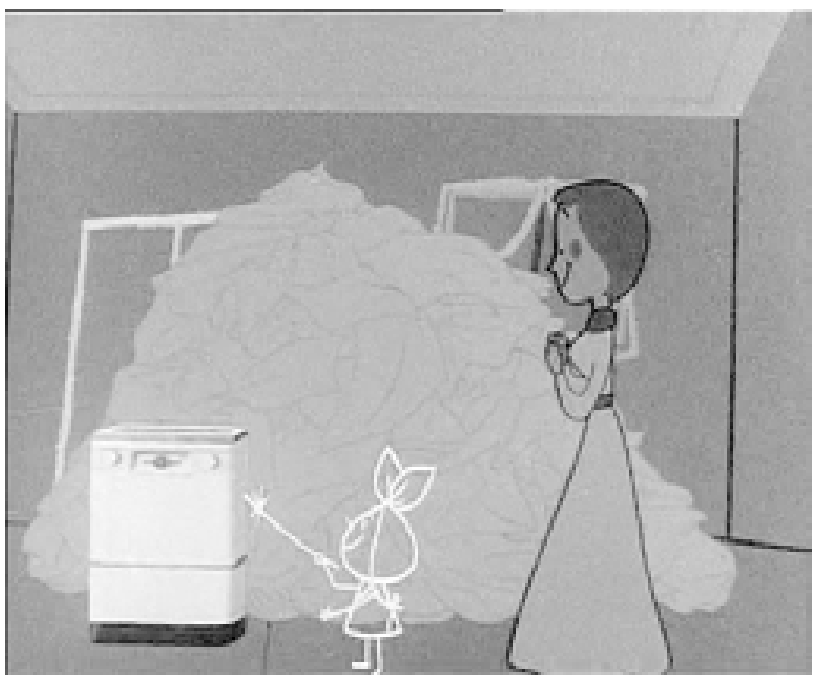

Figure 1: The Electricity Fairy, 1955. The fairy fills up the washing machine.

But the main purpose of the film is to show an electrical system in the house. Two versions of The Electricity Fairy exist. In the second one, the rooms are different and the small fairy adds a coffee machine to the list of appliances.

With regards to poster advertisements, the use of women as an icon for electricity had actually decreased since the 1930s. As electrical technology gradually lost its miraculous nature, the role of engineers was given more weight. The disenchantment of the world went hand in hand with its masculinization in the iconography. ${ }^{9}$ The comeback of the old symbol of the fairy in the films is a sign of the re-enchantment, not of the world but of the house. In the mid-1950s, the icon of the electricity fairy became modest: The area of action is limited to the house, whereas in the 1880 os its ambitions were quasi-universal. The films show a pattern of lifestyle where the appliances are not only "little electrical servants", as the ads said in the 1930s, but they are a system. The house is a closed world and electricity brings modernity into each room. The entire house is like the

9 | Yves Bouvier: “Images de l'électricité", in: So Watt! Du design dans l'énergie. Paris: Beaux Arts éditions, 2007, 10. 
modern kitchen: "[A] complex, technological artifact" which "embodies the ideology of the culture to which it belongs." 10 The link between electricity consumption and modernity was the main argument for EDF as an electricity supplier as it did not sell washing machines or fridges but rather the technological infrastructure needed for the use of these objects.

In fact, it was only from 1963 onwards that EDF reacted to changed patterns of consumption and that communication strategies took the turn of households' electricity consumption. After the depression of the 1930s, the deprivations of WWII and of the end of the 1940s and the rebuilding of the 1950s, an appetite for consumption was fed as the American consumerist pattern became a cultural reference. The American informal cultural empire, a mix of images and modern distribution systems, contributed to a change of European consumption. ${ }^{11}$ The extent of the 'Americanization' of Europe, however, is still heavily debated among historians: National references still remained strong especially in advertising. Consumption growth began during the last years of the 1950 s and increased steadily during the two following decades. The cultural factor was articulated with a deep social change: extremely rapid urbanization, with the percentage of people living in urban settings increasing from 55 to 73 percent between 1955 and 1975. This urbanization pattern produced a modification in the lifestyles of many and an access to 'modernity' symbolized by the car and the washing machine. ${ }^{12}$

The context also changed for energy consumption in households which were now able to buy electric appliances more often. Several stages can be described in the structuring of the French mass market of appliances. In 1953, the Syndicat général de la construction électrique (General trade union of electrical engineering), representing the manufacturers and EDF, established a joint financial corporation, Cetelem (meaning Credit for electric household appliances). Cetelem made loans for households that wished to buy electric appliances. Another stage was the standardization of the distribution network at the voltage of 220/230 V. In 1946, 86 percent of the subscribers were served by a network at 110/130 V. But most European

10 | Oldenziel: “Kitchen as Technology and Politics”, 2.

11 | Victoria de Grazia: Irresistible Empire: America's Advance through $20^{\text {th }}$ Century Europe. Cambridge, MA: Harvard University Press, 2005, 586.

12 | Kristin Ross: Fast Cars, Clean Bodies: Decolonization and Reordering of French Culture. Cambridge, MA: MIT Press, 1996, 273. 
countries had made the choice of $220 \mathrm{~V}$ and EDF decided to convert its distribution network. This rendered many electric appliances obsolete. With the support of French manufacturers (particularly Moulinex), upgrading the intake voltage of a household to 220 was accompanied by a free replacement of its electric appliances. The law of December $21^{\text {st }}, 1960$ prohibited the selling of appliances which could not function on $220 \mathrm{~V} .^{13}$ The third element is the decision of EDF managers to develop and apply a commercial strategy for the first time. EDF was, and still is, a company of engineers and high-level civil servants, accustomed to celebrating their production capacities. This new strategy was described in a paper from 1962 entitled "The Raising of Electricity Consumption in France" which stated that: "Electricity is a consumer good which needs to be developed. Electricity is an indispensable product for the social and economic balance of a country."14 The first advertising campaign resulted in a deep change of strategy within the company. On the occasion of EDF's board of directors meeting on February $23^{\text {rd }}, 1962$, a four-year plan of commercial action was presented in which the company adopted the ambitious objectives of the fourth national plan of equipment and modernization. ${ }^{15}$ Electricity consumption grew very quickly, doubling every ten years, and the users wanted to be able to use more and more electric household appliances without blowing fuses. In reality, irregularities in the network and insufficiently low voltage were the two reasons for lack of power in these homes. ${ }^{16}$ For the first time, EDF organized an advertising campaign on a national scale. The "blue meter campaign" was launched after rigorous preparation. The idea of the campaign was rather simple: In order to be able to use several appliances at once, it was necessary to have a good meter. Thus, the consumers had to install a meter with the necessary

13 | Jean-François Picard/Alain Beltran/Martine Bungener: Histoire(s) de l'EDF. Comment se sont prises les décisions de 1946 à nos jours. Paris: Dunod, 1985, 94.

14 | EDF Archives, 801043. Paper "The raising of electricity consumption in France", May 30, 1962.

15 | Jean Dubois: “Le réveil commercial d'EDF. Compteur bleu et chauffage électrique intégré", in: AHEF: L'électricité et ses consommateurs. Paris, PUF, 1987, 288.

16 | Patrice Carré/Alain Beltran: La fée et la servante. La société française face à l'électricité. XIXe-XXe siècles. Paris: Belin, 1991, 304-306. 
power. EDF decided to make this meter blue, as to distinguish it from older models. A house equipped with a "blue meter" became synonymous with modernity. By guaranteeing a power of $6 \mathrm{~kW}$, then four times the average power demand of an individual household, EDF "broke the deadlock of the power."17 The first campaign was bound to succeed. The consequences were dramatic: Domestic consumption, which represented 11.6 percent of the electricity national consumption in 1960, reached 30.2 percent in 1983 . EDF's commercial strategy followed consumer demand and advertisement strategies focused on electrical appliances.

This possibility to accumulate electrical appliances and electronics justified the "blue meter" campaign for EDF's managers in 1963. Three cartoons were shown in the cinema and one of them illustrates the matter for households perfectly.

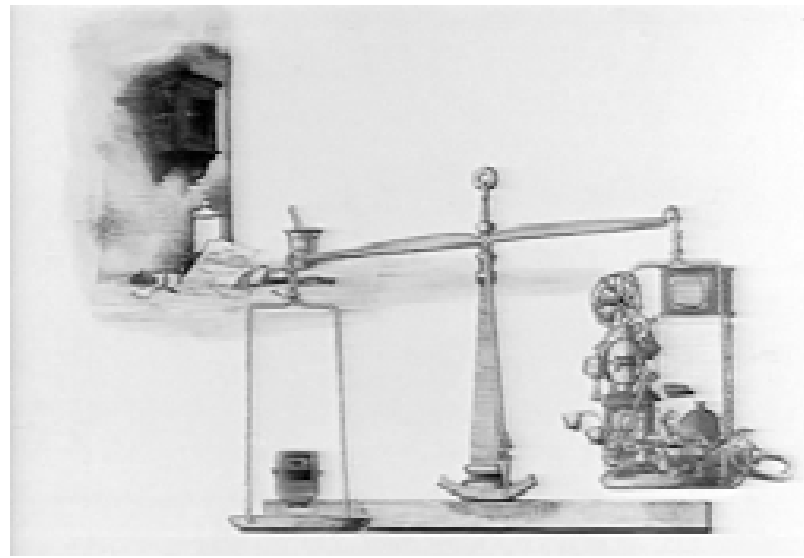

Figure 2: The Pair of Scales, 1963. A blue meter balances the accumulation of electrical appliances.

In the first shot of the cartoon The Pair of Scales (1963), we see an electric meter which progressively sweeps across several electrical appliances in the following shot (Fig. 2). About 13 objects were drawn in this cartoon including a television set, an electric flat iron, a coffee machine, a

17 | Jean Dubois: "La société de consommation électrique", in: Henri Morsel, ed. Histoire de l'électricité en France. t.3: Une œuvre nationale: l'équipement, la croissance de la demande, le nucléaire (1946-1987). Paris: Fayard, 1996, 643. 
refrigerator, a vacuum cleaner, an electric heater, a washing machine, a cooker, a whisk, a sewing machine, etc. As the meter sweeps the scene, the narrator says: "Your meter is saturated. How can you enjoy the comfort of all your electrical appliances? Get a blue meter and contact EDF." The words "incomparable electrical comfort" end the film. Using a meter to promote electricity consumption is at first surprising because it is the symbol of electricity as a consumer good (referring to measurement, control and price). But in this particular case, the symbol is reversed: The blue meter allowed a growth of electricity consumption and the constraints of material goods disappeared. In this campaign, the meter is perceived not just in its symbolic quality which usually refers to the expense of energy consumption, but rather the meter is presented as a technology making more consumption possible.

In the film advertisements discussed so far, the main moving force had been the accumulation of electrical appliances. Resorting to cartoons was a way to show this accumulation. The graphic effects possible thanks to animation are definitely visible in The Pair of Scales in which the number of the appliances makes the former electric meter obsolete. In the 1955 film The Electricity Fairy, six applications had been presented: lamp, radio, refrigerator, oven, water-heater and washing machine. Eight years later, there were no less than 13 appliances, including a TV, a fan, a washing machine, a sewing machine and a hair dryer. The concept of comfort itself had been transformed in a few years. Whereas comfort referred to the lessening of the more laborious household tasks in the middle of the 1950 , it became a lifestyle in the 1960 os. In other words, the ideology of comfort triumphed over the hopes of progress. This fast change corresponds to another way of conceiving energy: From this point in history, the idea of energy as a source of progress and modernity tended to disappear. During the 1950 s, electricity was a symbol of innovation, social progress and modernity. In the 1960 s, the metaphors of innovation and progress increasingly shifted from the energy sector toward the new sectors of computing and telecommunications. Advertisements accurately point out this shift in the meanings and representations of energy. In this new pattern, energy is no longer pictured as coming from the outside into the households (in the 1955 film the fairy enters the house through a window), but rather as something already integrated into the lives of the consumers. EDF no longer had to focus on convincing its consumers to use electricity because it had already become an integral part of French life at the time, 
but their insistence now was on the quality, regularity and safety of the product they provided. It is a way, for EDF, of following the rapid changes in French society. ${ }^{18}$ EDF presented itself as a silent partner in the daily life.

During the 1950s and the 1960s, the company sought to equate electricity to modernity, safety and comfort. This is a challenge which needs a mediator. The female figure was the fitting cultural icon for this equation. At the end of the 1960 s, the number of women employed was at its lowest level in the $20^{\text {th }}$ century: In 1968,60 percent of women between 20 and 60 years were housewives. This situation is partly explained by the French baby-boom between 1942 and 1975. Today, film scenes showing women in the kitchen while their husbands are idly sitting in an armchair seem like caricatures to us, but it is necessary to remember that those situations corresponded with the social norms of the time. These norms assigned the domestic area to women and, in fact, the female figures of these films are always shown indoors. They control and organize this closed world. ${ }^{19}$ When their husbands or children appear, these 'intruders' are relegated to secondary roles. In its promotional films, EDF reintroduced the woman as an actor of modernity. Women made most of the purchases (but, if we believe statistical data produced by $\mathrm{EDF}^{20}$, big electrical appliances were purchased by men), and so, are the mediators of the system of electric appliances. The following table shows that electric appliances took time to change French homes. We should notice that less than 50 percent of households had a refrigerator in the mid-196os.

18 | Jean Fourastié: Les trente glorieuses ou la Révolution invisible de 1946 à 1975. Paris: Fayard, 1979, 288. Michelle Zancarini-Fournel/Christian Delacroix: La France du temps présent, 1945-2005. Paris: Belin, 2010, 656.

19 | Jean-Claude Soulages: "Les avatars de la publicité télévisée ou les vies rêvées des femmes", in: Le temps des médias 12 (2009/1), 117.

20 | In 1958, EDF created a division Études économiques générales (global economic studies) to plan electricity demand and ordered statistical surveys. Robert Janin: “Convergence des pratiques technico-économiques à I'EDF (1946-1985)", in: Henri Morsel, ed. Histoire de l'électricité en France. t.3: Une œuvre nationale: l'équipement, la croissance de la demande, le nucléaire (1946-1987). Paris: Fayard, 1996, 371-75. 
Table 1: Proportion of French Households Equipped with Electrical Appliances, 1954-1982.

\begin{tabular}{|l|c|c|c|c|}
\hline & 1954 & 1964 & 1974 & 1982 \\
\hline Refrigerator & $7,5 \%$ & $46,7 \%$ & $87,3 \%$ & $98,6 \%$ \\
\hline Washing machine & $8,4 \%$ & $34,2 \%$ & $66,4 \%$ & $80,7 \%$ \\
\hline Dish washer & & & $5,3 \%$ & $18,9 \%$ \\
\hline Freezer & & & $10,2 \%$ & $30 \%$ \\
\hline
\end{tabular}

Contrary to the United States, France's favorite technologies of the 1950 s were also the favorite technologies of the 1960 s. Women were the users of electrical appliances because they were at home. But this historical context also explains why it took a relatively long time for the appliances to find their way into the households: their income was low because they relied on the single earning of the male breadwinner.

\section{Energy Saving and Consumers in Action, 1974-1992}

As in many countries of the developed world the oil price crisis of 1973 (quadrupling in October of that year) was a turning point in French energy history that created a radically new context. Consequently, the representation of energy also changed drastically from a formerly abundant to a now, almost instantly, scarce resource. The effects of the crisis were also immediate and radical on EDF. They developed two strategies to cope with the new situation: boosting nuclear power and promoting energy savings.

The government considerably accelerated the civil nuclear program that it had already launched in 1957. More than 50 nuclear reactors were planned, and the building of 18 reactors began between 1974 and 1977. Such a program was, in fact, a complete reshaping of the electricity production in France and led to the decline of traditional coal and fuel power stations. The aim of this policy, decided by President Pompidou in March 1974, was to reduce the nation's oil bill. France has a particular relationship to nuclear energy. Without detailing here the various components of the French 'nuclear choice', it is necessary to briefly discuss certain points. The French nuclear program, initially military, was started with the creation of the Commissariat à l'Energie Atomique (CEA) in 1945. Based on scientific 
knowledge and a team of worldwide reputable scientists (Frederic JoliotCurie, Francis Perrin), the CEA built experimental reactors and France obtained the atomic weapon in 1960 . From 1956 on, civil applications were studied, even though it took until 1963 to see the first French civil nuclear power plant producing electricity in Chinon on the left bank of the Loire. The civil nuclear program was and is studied, developed and managed by EDF. The choice of a public firm to lead the building of nuclear reactors expressed the hope that those reactors would provide reliable electricity production and did not represent simply technological experimentation. ${ }^{21}$ In 1969 , EDF made the first change in its nuclear policy by abandoning their initial French technical path, which was based on natural uranium as fuel, carbon dioxide as coolant and graphite as a moderator. Instead, EDF now adopted American technology (enriched uranium as fuel and pressurized water as coolant), which was first implemented for the nuclear power plant of Fessenheim, built between 1970 and 1977. The aim of the public authorities was to lead a 'Francization' of PWR (Pressurized Water Reactor) technology, a process which occurred during the 1970s by EDF and the manufacturers Creusot-Loire and Alsthom.

But the nuclear turn was not the only decision linked to the oil crisis. The government started an energy-saving policy. Law number 74-908 of October $29^{\text {th }}$, 1974, obliged energy suppliers to promote responsible behavior among consumers. ${ }^{22}$ Energy advertising was forbidden and the only message the suppliers were allowed to convey had to deal with energy saving. Consequently, EDF had to rework its communication policy. The firm was in a very delicate situation. On the one hand, it had to maintain, even raise, electricity consumption but on the other hand, the state-owned firm had to respect the government's energy policy. In 1974, EDF made two cartoon ads for TV: the first one about a washing-machine and the second one about a dishwasher. In both, the slogan was “Don't throw your kilowatt hours out of the window!" The message, however, was not as clear as the

21 | Gabrielle Hecht has shown the ambiguous relationship between EDF and the CEA. Gabrielle Hecht: The Radiance of France: Nuclear Power and National Identity after World War II. Cambridge, MA: MIT Press, 1998, 453.

22 | Aurore Toulon: "La sensibilisation de l'opinion publique aux économies d'énergie 1974-1986", in: Alain Beltran/Christophe Bouneau/Yves Bouvier/ Denis Varaschin/Jean-Pierre Williot, eds. État et énergie. $X I X^{e}-X X^{e}$ siècle, Paris: CHEFF, 2009, 263-264. 
slogan suggested. The second cartoon promoted the tag line: "Fill your machines up all the way to economize." The ambiguity of EDF's position is summarized in these cartoons: reconcile energy saving with economizing electricity consumption.

A real change in EDF's communication strategy occurred in 1977 when the company ordered six promotional films on consumer behavior. The advertising campaigns became more and more institutional in putting forward EDF's image. The main slogan of this period, in tune with energy saving slogans, was "men in the service of the people" (1979 campaign). Contrary to the promotional films of the affluent society of the 1950 s and 1960 s, the ads of the two following decades explicitly casted energy consumers in an active role. For the first time, the cartoons were replaced by movies with actors playing the role of ordinary consumers. Starting with this campaign, the films' characters - up until the most recent films - always lived in an electrified universe whose slogan was: "Use electricity; do not waste it." These advertisements accentuate the concrete character of these situations: using an overly large hotplate, filling a washing machine halfway, leaving the refrigerator door open, etc. Electrical appliances lost their "soul" by sacrificing drawn images for the realism of film: They became objects of the everyday life used by ordinary people. We have to be cautious in the analysis of these films. They seem to show "technology in the context of their use"23, but users are defined by the firm's idea about their projected users. Creating a concrete, uniform vision of everyday behavior is a trap in which we should not fall, and in these films electricity consumers are idealized based on an image EDF wanted to promote.

In the movie entitled The Cooking (1977), we see a woman boiling water on a large hotplate. Her husband and her father are seated, waiting for the coffee (Fig. 3). The father says: "Doesn't your saucepan get bored in the middle of that big hotplate." The woman then moves the saucepan from the big hotplate to a smaller one. The father says again: "Don't you need a flat saucepan instead of your badly dented saucepan? And perhaps you have to put a lid on it, and then the water will boil quicker." The woman asks him: "Hey Dad, do you know tricks for boiling water now?" And the man answers: "For water no. But I do for saving money."

23 | Oudshoorn: "How Users and Non-Users Matter", 2. 


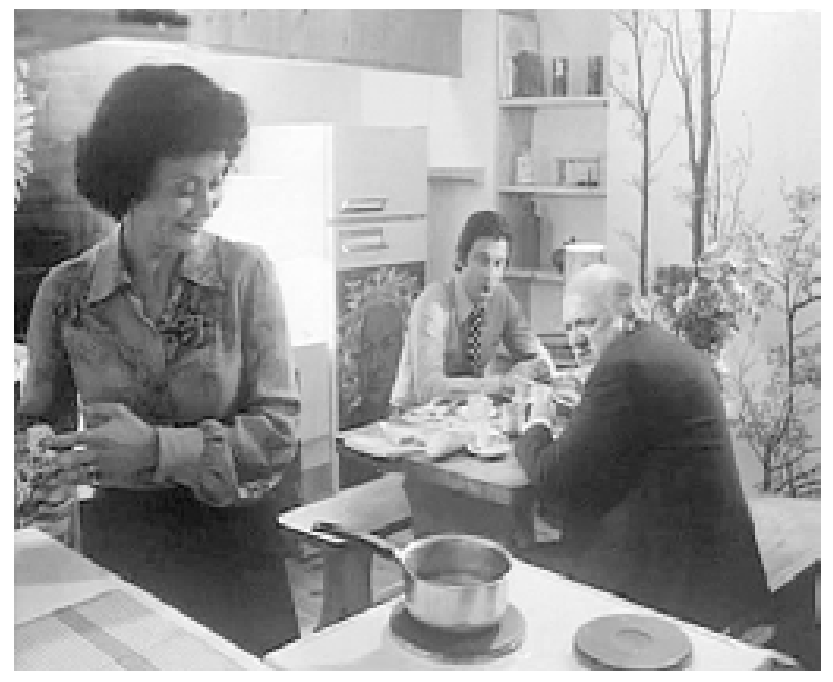

Figure 3: The Cooking, 1977. A typical situation to promote energy saving.

As we see in this example, the theme of the campaign was not consuming more electricity but consuming it efficiently. Dialogues centering around the accumulation of electrical appliances or on the gain of comfort, which had dominated the films of the 1950s, were now replaced by economic slogans such as: “Don't have your meter running for nothing” (1977 campaign). Electrical appliances had become everyday things and had lost their status as the protagonists of consumption in promotional films. If they still are 'vehicles of meaning', this meaning is restricted to energy saving. Now it was the consumer in person who stood in the center of the films. Electricity was shown as a consumer good and no longer as a symbol of modernity.

Another film in this campaign, The Washing Machine, depicts an old woman filling her washing machine. Her granddaughter suggests filling the machine up to the brim. In another film, the same scene is played out by a man and his son who scolds his father for turning on more lights than needed in the living-room. In a third film, it is also a young boy who tells his mother to close the refrigerator door. In these everyday scenes, the consumer in action does not show the most energy-conscious behavior and obviously needs advice. The role given to young boys and girls is a 
way of symbolizing the society's future, and also the future of electricity consumption.

What were the results of these energy saving campaigns? There were none. This table shows the repartition of electricity consumption by users, documenting a steady rise in electricity consumption of households from 1951 to 1984 .

Table 2: Repartition of Electricity Consumption by User Sectors.

\begin{tabular}{|l|r|r|c|c|}
\hline & \multicolumn{1}{|c|}{ 195I } & \multicolumn{1}{c|}{ 1963 } & \multicolumn{1}{c|}{ 1973 } & \multicolumn{1}{c|}{ 1984 } \\
\hline Industries & $24371 \mathrm{GWh}$ & $55273 \mathrm{GWh}$ & $95379 \mathrm{GWh}$ & $118644 \mathrm{GWh}$ \\
\hline Services & $5513 \mathrm{GWh}$ & $15351 \mathrm{GWh}$ & $34387 \mathrm{GWh}$ & $62545 \mathrm{GWh}$ \\
\hline Households & $3523 \mathrm{GWh}$ & $10367 \mathrm{GWh}$ & $30169 \mathrm{GWh}$ & $79830 \mathrm{GWh}$ \\
\hline $\begin{array}{l}\text { Percentage of } \\
\text { households in } \\
\begin{array}{l}\text { total of } \\
\text { electricity } \\
\text { consumption }\end{array}\end{array}$ & $10,55 \%$ & $12,80 \%$ & $18,86 \%$ & $30,58 \%$ \\
\hline
\end{tabular}

The share of households in electricity consumption reached nearly one third of the national consumption in the mid-1980s. In GWh, household consumption almost tripled in the ten years between 1974 and 1984 . Electricity consumption rose drastically after 1973 and it seems like the films did not work at all. This important peculiarity of the French energy system is due to electrical heating. Two reasons explain the choice of electrical heating: the reduction in cost of imported oil (fuel heating) and using cheap electricity provided by nuclear power plants at night. The proportion of new apartments equipped with electric heating grew from 10 percent in 1974 to 40 percent in 1977 and 72 percent in 1988 (compared to the European average that amounted to 21 percent of new apartments equipped with electrical heating in 1988). The example of electrical heating displays an ambiguity within the French energy policy: promoting energy savings in the time of vast nuclear propagation which is based on the growth of electricity consumption. EDF, as energy supplier, was of course affected by this duality. In EDF's promotional films, this ambiguity is also perceptible by the juxtaposition of two discourses on energy: consuming and saving. Consumers were the main agents in promotional films of this 
period. In other words, electricity was shown as a consumer good and occasionally as a national commodity.

\section{The New Electrical Comfort or the Reappearance of Electrical Appliances, 1992-2004}

The last of the three defining periods in promotional film marketing began with the 1992 campaign on nuclear energy. For the first time since 1974, it was not consumer behavior which was at the core of promotional films but, once again, as in the 1950 s and the 1960s, the electrical appliances. The 1992 campaign was made up of three films: The Drill, The Dance and The Dentist. In the first film, a character is using his electric drill to fix a shelf (Fig. 4).

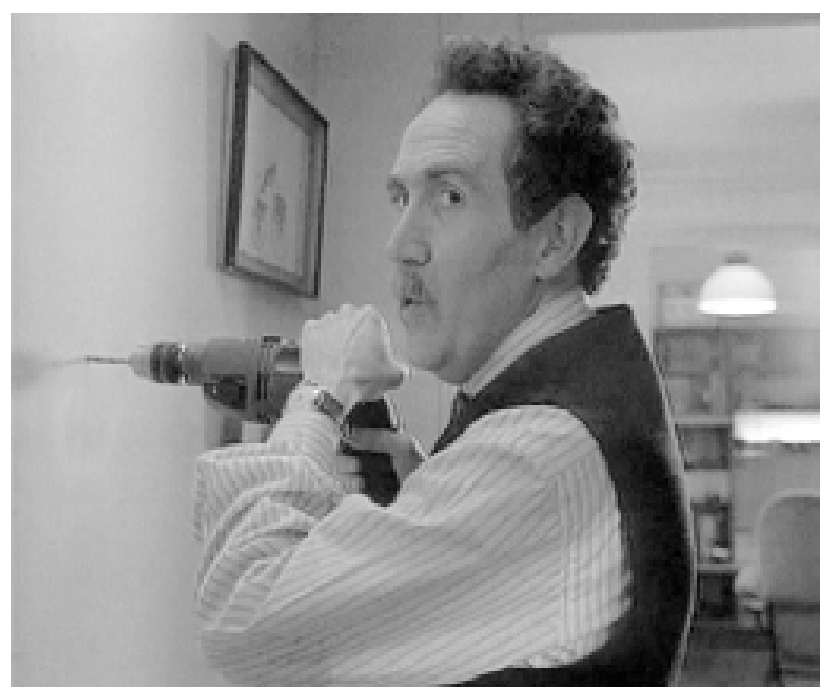

Figure 4: The Drill, 1992. "It's not an electric drill, it's a nuclear drill."

His neighbor, furious because of the noise, knocks at the door and says: "It's impossible to have some peace and quietness, even on a Sunday. Could you stop your damn drill?" The man answers: "My damn drill, my damn electric drill. Yes sir, electric." The neighbor angrily says: "Electric 
or not, your drill gets on my nerves." But the man, drill in hand, replies: "Electric drill, but you can also say my damn nuclear drill. Because when I bore through my wall - our wall I should say - it is thanks to the electricity, which is nuclear." This promotional film was broadcast in 1992 and 1993 on TV and the sentence "my nuclear drill" became a popular media reference in public discourse for several years. It is surprising to see such a campaign, which reminded consumers that 75 percent of electricity production came from nuclear energy, only six years after the Chernobyl disaster. In a way, the discourse on the nuclearization of the electrical appliances is an answer to the ambiguity that emerged in 1974 between production technologies (nuclear energy) and consumer behavior (energy saving). In Barthes' framework, the 'nuclear drill' could be a modern myth because "the meaning overflows the object's use." ${ }^{24}$ These three films directly link electrical appliances with their production process and with EDF's industrial choices. The objects are parts of a global productive system and the drill is the bearer of meaning.

While electrical appliances made a reappearance in EDF's promotional campaigns, the campaigns themselves became more diverse. Consumers and appliances were the focus of only 14 out of 35 advertising films during this period. The ecological argument shaped many of the other films and nuclear energy was presented as a way to reduce the nation's oil bill. From the beginning of the 2000 s, nuclear reactors also began to be presented as low-carbon energy. In this direction, several institutional films showed the attachment of EDF to sustainable development: solar energy in Africa, wind energy, rational energy consumption in cities and so on. All the promotional films, even for electric heating, favorably mention energy saving, since the law of 1974 still applies.

In the 2000 s, the corporate image of EDF became a strategic field to prepare the open offer of shares. These various communication strategies suited the variety of energy-related issues as described by David Nye: "At the end of the twentieth century, consuming power had become at once a technical question, an ecological dilemma, an economic field, a political problem, and a highly personal matter."25 This explains why electrical applications are only a branch of the communication strategy. But in one

24 | Barthes: "Semantics of the Object", 182.

25 | David E. Nye: Consuming Power. A Social History of American Energies. $3^{\text {rd }}$ ed. Cambridge, MA: MIT Press, 2001, 250-251. 
third of the communication actions, they still remain at the center of promotional films.

The reappearance of electrical appliances was not simply a fashion. It began in the mid-1980s when the designers tried to create new appliances, using electronic technologies and recyclable materials. The 1960s and 1970 s were two decades of standardization while the 1990 os was a decade of new design. ${ }^{26}$ This trend materialized in the interactive technologies which are now integrated in electrical appliances (screen, program, variety of functions). EDF's promotional films followed this trend. The film entitled The Boat (1992) shows a man in a small boat, rowing to cross the Atlantic Ocean and dreaming of the electrical comfort of his home by recounting each of his appliances: an electric blanket, a toaster, a kettle, a micro-wave oven, a water heater, etc. The appliances named in this film are quite different from the list of the electrical appliances present in the $1960 \mathrm{~s}$ (refrigerator, washing machine). Now, comfort is not something magic, it is merely normal and the electrical appliances are more everyday objects. It is not their use but their absence which reminds the consumer of their utility. ${ }^{27}$

The sentence "the new electrical comfort" was used for the first time in 1997 in the film Marie-Amélie. A little girl, named Marie-Amélie, walks around in her home and notes the appliances of this new comfort: micro-wave oven, videogames, and air-conditioning (Fig. 5). She is also the narrator and comments to herself on the world she explores as the appliances are seen through her eyes. "The natives are very sociable," she says when she sees her brothers playing video games. "The kitchen is as warm as the milk," she says as she passes the thermostat because the electric heating adapts the temperature for each room. "The rain is always at the right temperature," when she passes the bathroom where her mother showers. The colors of this film (orange, yellow) are a reference to the 1970s, the period of the birth of the film's older characters. This film

26 | Andrea Branzi: "Disparition et retour des serviteurs fidèles", in: Raymond Guidot/Marie-Laure Jousset, eds.: Les bons génies de la vie domestique. Paris: Éditions du Centre Pompidou, 2000, 162.

27 | Paul Virilio named this process "the aesthetics of disappearance". Paul Virilio: Esthétique de la disparition. Paris: Galilée, 1989, 126. 
illustrates perfectly the fact that "the high-energy society was increasingly a white-collar world."28

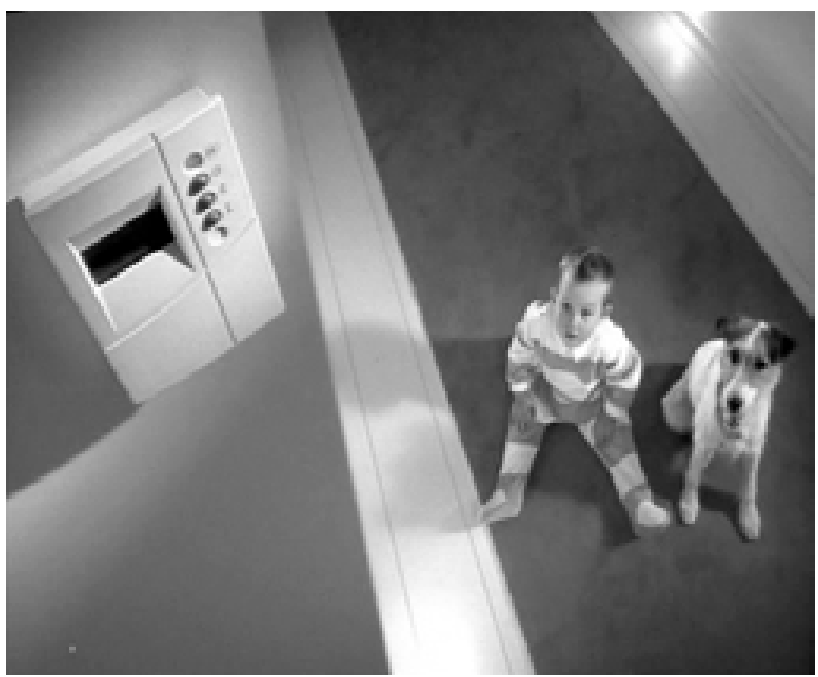

Figure 5: Marie-Amélie and the New Electrical Comfort, 1997. Marie-Amelie is looking at the thermostat which regulates the temperature in each room.

The woman is not doing domestic work but takes a shower; the man is not watching TV but watering plants. Of course we can see in this film that the new electrical comfort is based on new electrical appliances. The washing machine, the dish washer and the electric iron have disappeared. The meaning carried by objects is quite clear: Objects communicate and adapt their energy consumption to consumer behavior without any consumer action. But neither the appliances nor the consumers are the main agents of this promotional film: The key role is the architect of this lifestyle, EDF. Electricity consumers have become passive in this ideal home shaped by the energy supplier.

28 | Nye: Consuming Power, 208. 


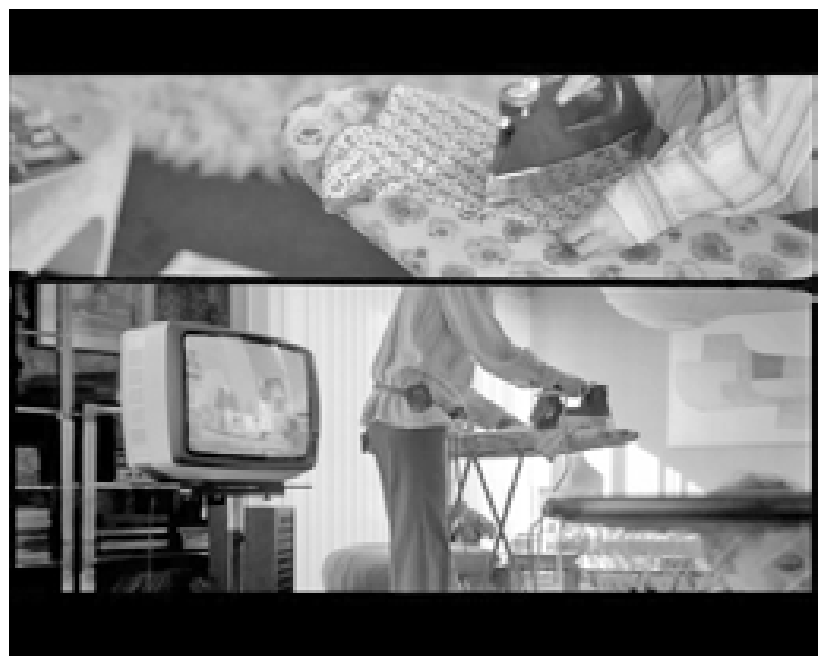

Figure 6: Objects, 2004. Everyday things dominate the scene while the consumer remains faceless.

This strategy was further developed in the film Objects (2004). This was the year of EDF's status change. This film relates the life of a man without showing his face (Fig. 6). More than 6o electrical appliances appear during the 60 seconds of the film, illustrating the "hyper-consumer society." 29 We can imagine that he was born during the first half of the 1970s and we see the electrically operated objects of his life: bottle-warmer, orange yogurt-maker, toaster, string of lights on a Christmas tree, alarm clock, hair clippers, TGV train, drill, heater, coffee-machine, subway car, elevator, fax machine, and computer. The electrical artifacts are celebrated as a substitute for identity. There is no narrator or slogan, just music ("The End has no End", by The Strokes) and the objects. The screen is divided into two or three parts, sometimes horizontally and sometimes vertically. In each window, we can see an object in use. In this film, the omnipresence of electrical appliances causes the disappearance of the consumer. EDF writes the history of a generation by filming a succession of electrical appliances.

29 | Gilles Lipovestsky: “La société d'hyperconsommation", in: Le Débat 124 (March-April 2003), 74-98. 
Consumers and technology have fused together under the patronage of the electric supplier.

\section{Conclusion}

Two conclusions should be made to end this paper. The first deals with the social relationship to energy and the second with the construction of cultural representations. EDF's promotional films allow us to distinguish three socio-cultural relationships to energy. The cartoons of the 1950 s and 1960 s associated electricity consumption with usefulness (this theme had also been the main slogan of the advertisements in the interwar period) and comfort. The housewife was the leader in the modernization of French homes but, in promotional films, the main agents were the electrical appliances. The system of electrical objects shaped a closed world, apparently independent of the electricity network or of the production technologies.

This pattern changed with the 1973 oil crisis. Consumers took over the main role in promotional films and the ideology of comfort was replaced by advice on energy-efficient behavior. Electricity consumption had lost its magical halo and the concrete situations shown in the films were strengthened by the substitution of cartoons with movies. Of course, this change followed the general trend of the growth of the marketing budget. At this time of energy saving, energy consumption became an economic affair for individual households but also for the nation. More efficient electricity consumption was presented as a solution to the energy crisis. A communication strategy was created that used energy as a consumer good.

For two decades, the relationship established between energy and the consumer, as staged in the promotional films, was a cultural lifestyle. The reappearance of electrical appliances in promotional films of the 1990 s and 2000 did away with the role of consumers in the films and put forward the role of the supplier.

This paper has illustrated the idea that energy is a socio-cultural construction. But this construction is also created by other power companies the world over. David Nye has expressed this idea in his book about the photographic collection of General Electric: "Thus, if these images emerged 
from the necessities of corporate communication and from routinized work in the photographic department, they nevertheless did not serve to reinforce or reify an older social order but to visualize a new one." ${ }^{\circ}$ In this way, EDF's films are not only products of the marketing strategy but also milestones in the construction of energy as a socio-cultural commodity.

In the films I analyzed, EDF consistently used stereotypes and prevailing social norms from the time of the films' making. The rapid changes in technological and economic context over the course of the $20^{\text {th }}$ century have created new cultural relationships with electricity. Advertisements are relevant reflections of EDF's ambiguous and sometimes wavering strategies. The cultural relations I tried to identify between consumers and electricity are, finally, compromises between the state of technology, economic public policy, prevailing social norms and the strategies of an industrial company.

\section{References}

Barthes, Roland. Mythologies. Paris: Seuil, 1970.

—. The Semiotic Challenge. Berkeley: University of California Press, 1994.

Baudrillard, Jean. Le système des objets. Paris: Gallimard, 1968.

—. La société de consommation. Ses mythes. Ses structures. Paris: Denoël, 1970.

Beltran, Alain/Bouneau, Christophe/Bouvier, Yves/Varaschin, Denis/ Williot Jean-Pierre, eds. État et énergie. XIXe-XXe siècle. Paris: CHEFF, 2009 .

Bodon, Virginie. La modernité au village. Tignes, Savines, Ubaye... La submersion de communes rurales au nom de lintérêt général. 1920-1970. Grenoble: Presses universitaires de Grenoble, 2003.

Bouvier, Yves. "Images de l'électricité”, in: So Watt! Du design dans l'énergie. Paris: Beaux Arts éditions, 2007, 10-12.

Branzi, Andrea. "Disparition et retour des serviteurs fidèles”, in: Raymond Guidot/Marie-Laure Jousset, eds. Les bons génies de la vie domestique. Paris: Éditions du Centre Pompidou, 2000, 161-64.

Carré, Patrice/Beltran, Alain. La fée et la servante. La société française face à l'électricité. XIXe-XXe siècles. Paris: Belin, 1991.

30 | Nye: Image Worlds, 155, 188. 
Dubois, Jean. “Le réveil commercial d’EDF. Compteur bleu et chauffage électrique intégré”, in: AHEF. L'électricité et ses consommateurs. Paris: PUF, 1987, 287-94.

—. "La société de consommation électrique", in: Henri Morsel, ed. Histoire de l'électricité en France.t.3: Une œuvre nationale : l'équipement, la croissance de la demande, le nucléaire (1946-1987). Paris: Fayard, 1996, 577-672.

Fourastié, Jean. Les trente glorieuses ou la Révolution invisible de 1946 à 1975. Paris: Fayard, 1979.

Fridenson, Patrick. "Réflexions sur les étapes de la nationalisation de l'électricité”, in: AHEF. La nationalisation de l'électricité en France. Nécessité technique ou logique politique? Paris: PUF, 1996, 381-92.

de Grazia, Victoria. Irresistible Empire: America's Advance through $20^{\text {th }}$ Century Europe. Cambridge, MA: Harvard University Press, 2005.

Hecht, Gabrielle. The Radiance of France: Nuclear Power and National Identity after World War II. Cambridge, MA: MIT Press, 1998.

Janin, Robert. "Convergence des pratiques technico-économiques à l'EDF (1946-1985)”, in: Henri Morsel, ed. Histoire de l'électricité en France. t.3: Uni œuvre nationale: l'équipement, la croissance de la demande, le nucléaire (1946-1987). Paris : Fayard, 1996, 371-75.

Leymonerie, Claire. "Des formes à consommer. Pensées et pratiques du design industriel en France (1945-1980)" (Unpublished Ph.D. diss., EHESS-Université Toulouse II, 2010).

Lipovestsky, Gilles. “La société d'hyperconsommation”, in: Le Débat 124 (March-April 2003), 74-98.

Nye, David E. Image Worlds. Corporate Identities at General Electric, 18901930. Cambridge, MA: MIT Press, 1985.

-. Consuming Power. A Social History of American Energies. 3rd ed. Cambridge, MA: MIT Press, 2001.

Oldenziel, Ruth/Zachmann, Karin. Cold War Kitchen. Americanization, Technology and European Users. Cambridge, MA: MIT Press, 2009.

Oudshoorn, Nelly/Pinch, Trevor, eds. How Users Matter. The Co-Construction of Users and Technology. Cambridge, MA: MIT Press, 2003.

Picard, Jean-François/Beltran, Alain/Bungener, Martine. Histoire(s) de l'EDF. Comment se sont prises les décisions de 1946 à nos jours. Paris: Dunod, 1985 .

Ross, Kristin. Fast Cars, Clean Bodies: Decolonization and Reordering of French Culture. Cambridge, MA: MIT Press, 1996. 
Soulages, Jean-Claude. "Les avatars de la publicité télévisée ou les vies rêvées des femmes”, in: Le temps des médias 12:1 (2009), 114-24.

Toulon, Aurore. "La sensibilisation de l'opinion publique aux économies d'énergie 1974-1986", in: Alain Beltran/Christophe Bouneau/Yves Bouvier/Denis Varaschin/Jean-Pierre Williot, eds. État et énergie. XIX $X X^{e}$ siècle, Paris: CHEFF, 2009, 260-286.

Varaschin, Denis. Tignes, la naissance d’un géant. Arras: Artois Presses Université, 2001.

Virilio, Paul. Esthétique de la disparition. Paris: Galilée, 1989.

Zancarini-Fournel, Michelle/Delacroix, Christian. La France du temps présent, 1945-2005. Paris: Belin, 2010. 

Energy Consumption Practices 



\title{
Managing Energy Consumption
}

\author{
The Rental Business for Storage Water Heaters of \\ Berlin's Electricity Company from the Late 1920s \\ to the Early 1960s
}

\section{NINA LORKOWSKI}

Having a wash, a shower, a bath - behind the bathroom door a lot of energy is consumed every day, in particular for water heating. Modern households' warm water heaters are mainly powered with electricity. They can provide warm water on demand and in no time. Today's water heaters work so well that we don't even think about the appliance working in the background. However, it is worth asking how this appliance became accepted in private households and how standards of cleanliness and convenience have changed since its introduction. ${ }^{1}$ Instead of having a wash in the weekly bath, today we shower at least several times a week or take a bath just for relaxation.

The electric industry promoted water heaters since the 1920 s in order to encourage residential electricity consumption not only with regard to a quantitative increase of electricity supply but rather to improve the efficiency of power plants. ${ }^{2}$ The main challenge for an efficient capacity utilization is the fact that electricity is not storable. Electricity must be produced and

1 | Cf. on changing consumers' expectations and practices of personal hygiene: Elizabeth Shove: Comfort, Cleanliness and Convenience. The Social Organization of Normality. Oxford: Berg, 2003.

2 | Frauke Langguth: “'Elektrizität in jedem Gerät'. Die Elektrifizierung der privaten Haushalte am Beispiel Berlins”, in: Barbara Orland, ed. Haushalts-Träume. Ein Jahrhundert Technisierung und Rationalisierung im Haushalt. Königstein im Taunus: Langewiesche, 1990, 93-102. 
transmitted when it is needed. This became especially important with the economic boom during the interwar period. The increase of industrial electricity consumption and a growing number of households connected to the grid called for expanding power plant capacities. A power network is a large technological system. When it grows, all of its elements have to change accordingly. ${ }^{3}$

In order to achieve improved efficiency of their power plants' capacities, utility companies in Germany and Europe saw great promise in the use of specific household appliances which could compensate for lower electricity demand during off-peak hours, when these expanded power plant capacities were not fully utilized. Even though energy is not storable, there are appliances whose energy consumption does not necessarily coincide with its usage. Such an appliance is the thermal storage water heater: It is possible to heat up the hot water tank during the night with electricity that can be supplied at a low price and that is then used as thermal energy during the day. ${ }^{4}$ Therefore, utility companies tried to install thermal storage water heaters in private households by offering special installment schemes and even renting them out to their customers. Furthermore, they encouraged the use of electricity for water heating by providing special rates. The systematic promotion of electric water heating as a means for selling off-peak power was common in many German cities ${ }^{5}$ as well as in other European countries and proved to be so successful that it was even adopted in the United States. ${ }^{6}$

3 | Cf. Thomas P. Hughes' notion of the power network as a system in his Networks of Power. Electrification in Western Society, 1880-1930. Baltimore, MD: Johns Hopkins University Press, 1983.

4 | J. Schwarz: “Die gegenwärtige Marktsituation für elektrische Heißwasserbereiter", in: Elektrizität. Zeitschrift für Abnehmerberatung. Organ der Hauptberatungsstelle für Elektrizitätsanwendung (HEA) 9:4 (1959), 80.

5 | Sven Tetzlaff: “'Laß mich hinein...!' Die Eroberung der Haushalte durch die Elektrizitätswirtschaft", in: Ursula Schneider/Detlef Stender, eds. Das Paradies kommt wieder. Hamburg: VSA Verlag, 10-25.

6 | "Amerika und das Problem des Heißwasserspeichers", in: Elektrizitätswirtschaft. Mitteilungen der Vereinigung der Elektrizitätswerke 29 (1928), 612. 
This article takes a closer look on the rental service for storage water heaters of Berlin's utility company “Berliner Kraft- und Licht-AG” (Bewag). ${ }^{7}$ It was introduced in 1929 as a strategy to push the household mechanization and electrification and influenced the manner of electricity consumption. Bewag supplied electricity for the whole city of Berlin. Private households evolved as important power network users in the densely populated city. After World War II, the company was divided and Bewag lost 40 percent of its supply area. It was not until the German reunification that Bewag's supply areas were reunited again. ${ }^{8}$

However, electric power companies could not simply impose the adoption of new technologies without active participation of the consumer. The history of household mechanization is characterized by the interplay of institutions and organizations of manufacturers, experts and last but not least, consumers. Women in particular, who organized themselves in consumers' or housewives' associations played an important part in the process of household mechanization when they collaborated with engineers, architects, businessmen, municipal agencies, doctors etc. in order to bridge the knowledge gap between the producers and experts and the users of household technology. 9

In this article, I shall not focus on consumers represented by organizations or institutions. Rather, I wish to examine how the designing engineers projected the users of their products on the one hand and how

7 | Initially Berlin's electricity company was called "Städtische ElektrizitätsWerke" and renamed "Berliner Kraft- und Licht-AG" in 1934. For the sake of coherency I will use the name Bewag throughout the paper.

8 | Berliner Kraft-und-Licht-(Bewag)-Aktiengesellschaft, ed. 100 Jahre Strom für Berlin. Ein Streifzug durch unsere Geschichte in Wort und Bild, 1884-1984. Berlin: Bewag, 1984, n.p.

9 | Karin Zachmann: "Technik, Konsum und Geschlecht - Nutzer/innen als Akteur/innen in Technisierungsprozessen”, in: Petra Lucht/Tanja Paulitz, eds. Recodierungen des Wissens. Stand und Perspektiven der Geschlechterforschung in Naturwissenschaft und Technik. Frankfurt/Main: Campus, 2008, 69-86; Caroll Pursell: "Domesticating Modernity: The Electrical Association for Women, 192486", in: The British Journal for the History of Science 32:1 (1999), 47-67; Martina Heßler: "Die Einführung elektrischer Haushaltsgeräte in der Zwischenkriegszeit. Der Angebotspush der Produzenten und die Reaktion der KonsumentInnen", in: Technikgeschichte 65:4 (1998), 297-311. 
the real users adopted the appliances, on the other. The differentiation between projected and real consumers and a perspective that moves constantly between both is inspired by Madeleine Akrich's concept of the de-scription of technical objects. ${ }^{10}$ Following her notion of technological appliances as an outcome of a negotiation process between producers and consumers, I shall analyze how the design of storage water heaters and their rental conditions have been negotiated between the utility company Bewag and its customers. I will follow the development of the rental service and its changing conditions. By its specific setting and design of installation and service, Bewag's engineers inscribed certain ideas of electricity usage into the appliance. Consumers adjusted to the appliance and the inscribed expectations of its use in their daily routines - or failed to adjust in case of diverging expectations of consumers and producers. Bewag's strategy to balance load curves repeatedly fell short because of the intractability of consumers' behaviour. In reality, there are various ways of using a technological artefact. By incorporating an appliance into their daily routines, consumers reshape the script that producers, i.e. the utility company Bewag, initially provided for them. Therefore, I shall enquire how the outcome of this, metaphorically speaking, negotiation process is translated into the appliance or the service provided.

The sources for this article originate from Bewag's company archive in Berlin (today Vattenfall) and have been complemented by magazines of the electrical industry in order to analyse the changing setting of the rental service and its appliance. The article will portray the development of the rental service and its changing ensemble of appliances and rental conditions over the years and compare the two periods of rental and installment service for storage water heaters from 1926-1941 and 19531975. Beginning with the introduction of a hire-purchase scheme in 1926, I shall describe how Bewag attempted to systematically influence the manner of energy consumption by promoting certain appliances. The article will subsequently discuss the conditions of the rental service that were modified with changing economical conditions. Finally, the rental service was restarted in 1953. Its new orders provide evidence of a modified consumption regime that became a challenge for attempts to influence

10 | Madeleine Akrich: "The De-Scription of Technical Objects", in: Wiebe E. Bijker/John Law, eds. Shaping Technology/Building Society: Studies in Sociotechnical Change. Cambridge, MA: MIT Press, 1992, 205-24. 
energy consumption. Simultaneously, this period marks the transition to the high-energy society. In the end, Bewag was no longer trying to adjust electricity consumption to technical demands in order to increase the efficiency of electricity production. Rather, they adapted electricity supply to changing consumption habits - to a prospective consumption regime of energy abundance - by expanding power network capacities.

\section{Developing the Power Network and Making Appliances Available}

When Bewag discovered private households as a promising market in the 1920s, residential electricity consumption seemed to be a valuable opportunity to optimize the load factor of power plant capacities by adding additional non-industrial electricity consumption. Thus, Bewag was required to compete more effectively with the gas industry. With the increase of electricity supply, private households became especially important as customers. Bewag expected at that time that electricity consumption would grow, not least because an increasing number of households had been connected to the grid since the beginning of the decade. At that time Bewag's energy provision was not covered completely by its own power plants but depended on long-distance supply from power plants outside their supply area. Expecting an increasing electricity demand, Bewag decided in the 1920 s to become more independent from long-distance power supplies and wanted to shift their activities toward producing electricity on their own instead of buying and distributing electricity that had been generated elsewhere. For these reasons, Bewag started running a new large-scale power plant in 1926 and expanded machine capacities of existing power plants. ${ }^{11}$

In Berlin, more than 50 percent of all households had electricity available in $1927 .^{12}$ Yet, at this time electricity was almost exclusively used for lighting

11 C. Matschoß/E. Schulz/A. Th. Groß, eds. 50 Jahre Berliner Elektrizitätswerke. 1884-1934 (=Veröffentlichungen der Bewag II. Vol 14). Berlin: VDI-Verlag, 1934, 56-57.

12 | Christian Stadelmann: "Strom für alle. Schritte der Elektrifizierung und Geräteausstattung des Haushalts bis zur Mitte des 20. Jahrhunderts", in: Blätter für Technikgeschichte 66/67 (2004/05), 117-41. 
and most households were only modestly equipped with technical devices. At the time, household appliances were expensive consumer goods that were hardly affordable for the average household. The German market for consumer goods was rather small and catered to the needs of a wealthy consumer elite. In the United States, by contrast, the market was less determined by class boundaries. ${ }^{13}$ In particular the provision of appliances on installment schemes had proven a success in stimulating consumption for durable and more expensive goods in the United States. In order to pursue their idea of the household as an increasingly important electricity consumer, German utility companies began to mediate and distribute household appliances. ${ }^{14}$ Following the American example, the electricity as well as the gas industry offered low-priced household appliances and made them available for installment schemes. ${ }^{15}$ Bewag was the pioneer in establishing a hire-purchase scheme in Germany. ${ }^{16}$ It was introduced in 1926 and came to be known as Elektrissima or $\mathrm{E}^{3}$.

Consumers used Elektrissima mainly to secure electricity supply in their homes. The most popular devices purchased with Elektrissima were small ones with a low load such as heating pads, hair dryers, electric irons and vacuum cleaners. ${ }^{17}$ Residential electricity consumption increased, but it was mainly used for lighting. This caused peak loads that still overlapped with industrial peaks loads. For this reason, improving the balance of load factors on power plants became more important than increasing overall

13 | Victoria de Grazia: “Changing Consumption Regimes in Europe, 1930-1970. Comparative Perspectives on the Distribution Problem", in: Susan Strasser/ Charles McGovern/Matthias Judt, eds. Getting and Spending. European and American Consumer Societies in the Twentieth Century. Cambridge: Cambridge University Press, 1998, 67-68.

14 | Martina Heßler: 'Mrs. Modern Woman'. Zur Sozial- und Kulturgeschichte der Haushaltstechnisierung. Frankfurt/Main: Campus, 2001, 136-48.

15 | Langguth: "Elektrizität in jedem Gerät”, 96-97.

16 | Herbert F. Müller: “Elektrizitätswerke als Absatzvermittler”, in: Elektrizitätswirtschaft 25:2 (1926), 77.

17 | Frauke Langguth: "Zur Geschichte der Elektrifizierung der privaten Haushalte. Die Absatzpolitik der Bewag gegenüber den privaten Haushalten in Berlin während der Weimarer Republik" (Unpublished Master thesis, TU Berlin, 1988), 77-78. 
electricity consumption of households. ${ }^{18}$ As a result, Bewag established a "Büro für Sonderaufgaben" (office for special tasks, N.L.) in 1928. It was charged with improving the development and marketing of household appliances in order to increase the use of off-peak power. ${ }^{19}$ Bewag especially focused its marketing strategies on electric stoves and water heaters, which were supposed to be used regularly and had a higher load factor.

\section{"Storing" Electricity}

Facing the problem of producing and selling a product that is not storable, the electricity industry recognized the potential of private households as, metaphorically speaking, a means of electricity storage. By the use of certain appliances, it was possible to influence the manner of electricity consumption and match it to the loads of the electric power company. A water heater could, when charged during the night, store electric energy to be consumed as heat energy during the day. Therefore, the implementation of storage water heaters into private households ranked first for the "Büro für Sonderaufgaben".

A storage water heater is not just a simple electric consumer good, but rather an installation. Connected to two networks, the waterline and the power circuit, it requires professional placement. It was furthermore equipped with armature, a special meter and a time switch. This made the appliance expensive for purchase and required regular maintenance service. ${ }^{20}$ It was not before the 1950 s that bathrooms became a standard element of dwellings and coal was still the most common fuel for heating water, because operation costs were low and boilers that were powered with fossil fuels also heated up the bathroom. Therefore, Bewag's customers had little interest in buying electrical water heaters, even though the company offered to sell them by installment payment. Thus, from 1929 onward, Bewag provided water heaters also for rent. The rental service provided

18 | Langguth: “Elektrizität in jedem Gerät”, 97-98.

19 | Berliner Städtische Elektrizitätswerke Akt.-Ges., ed.: Jahrbuch der Verkehrsdirektion 1929. Berlin, 1930, 43.

20 | H. Wasserzier: "Grundlagen der mietweisen Abgabe von Heißwasserspeichern durch das Elektrizitätswerk”, in: Elektrizitätswirtschaft 30:12 (1931), 351-53. 
customers with the necessary installation work, including a second electric meter, and a regular maintenance service. At first, Bewag rented out 1,000 heaters with a volume of 30,50 or 80 litres, mainly expecting to supply households with smaller water heaters for the kitchen or for taking a shower. The rent for the water heater was added to the monthly electricity bill and ranged from 3.75 to 5.00 Reichsmark, depending on the size (Fig. 1). ${ }^{21}$ Bewag introduced the appliance together with a special discount for night-time power usage. Between 8 p.m. and 6 a.m. the price of power was reduced from the average standard rate of 18 to 8 Reichspfennig. ${ }^{22}$

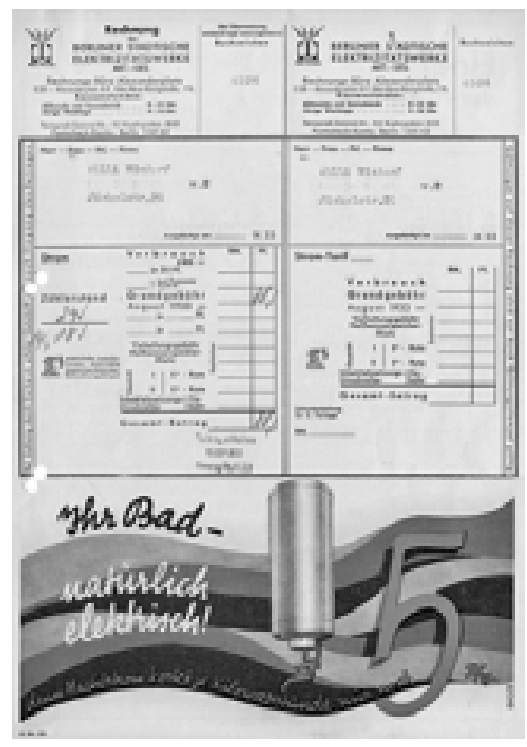

Figure 1: Electrity Bill with Box for Charging Storage Water Heater Rent, 1933.

The inexpensive rate was intended to convince consumers to rent the appliance. The heating-up periods were restricted to night-time hours and consumers could not choose between the two rates according to their demands. Bewag designed the installation in terms of their interest in selling exclusively off-peak power. Therefore, the proper use of the

21 | Jahrbuch der Verkehrsdirektion 1929, 45.

22 | Berliner Kraft-und-Licht-(Bewag)-Aktiengesellschaft: 100 Jahre Strom, n.p. 
appliance, running it only with off-peak power was regulated by the interplay of appliance design, meter and time switch.

\section{Regulating Energy Consumption by Appliance AND Installation DESIGN}

Initially, consumers could choose between two models of storage heaters: a drawdown storage heater or an overflow storage heater. In terms of their operation, they differed mainly in the degree of automation. A drawdown heater had to be replenished by the consumer, at least in the evening to heat it up during the night. Therefore, depending on their hot water needs, the consumers defined the amount of hot water that was heated in the tank of the drawdown heater. ${ }^{23}$ In contrast, when hot water was tapped out of an overflow storage heater, cold water replenished the tank automatically. When the overflow storage heater was exclusively heated up during the night, the water's temperature decreased the more water was tapped from the tank during the day. Even when no water was tapped at all, heat losses during the day called for heating the water during the night. ${ }^{24}$ But in contrast to the drawdown storage heater, the full volume of the tank was heated up during the night, without the possibility to adjust the volume to the prospected demand and to avoid heat losses of water that was not needed.

Heating-up times were controlled by a time switch. Storage water heaters were installed with an extra meter, separated from the main meter. ${ }^{25}$ At the beginning of the defined heating period the timer switched the relay circuit and connected the meter to the electric power supply, which provided the water heater with electricity. At the end of the defined heating period, the

23 | "Entleerungsspeicher für die Warmwasserversorgung von Siedlungen. Mitteilung der Fabrik für Elektrobeheizung, Abteilung Vertrieb", in: AEG-Mitteilungen 3 (1931), 185-86.

24 | "Untersuchungsmethoden für die Beurteilung der wärmetechnischen Eigenschaften von elektrisch-beheizten Warmwasserspeichern", in: Elektrizitätswirtschaft 25:1 (1926), 485-88.

25 | Ihno Thiemens: "Die Wirtschaftlichkeit des vollelektrischen Haushaltes für das Elektrizitätswerk mit besonderer Berücksichtigung der Heißwasserbereitung (Nachtrag)", in: Elektrizitätswirtschaft 31:30 (1938), 795. 
relay circuit switched off the power supply again. ${ }^{26}$ Thus, consumers were not able to adjust the water's heating-up periods to their requirements. When the water in the tank was cold, caused by the replenishment with cold water and heat losses, it was not until the next morning that warm water was available again. The only thing consumers had control over was switching the appliance off completely when it was not needed for a longer period of time. ${ }^{27}$

Shortly after the introduction of both the hire-purchase and the rental service, Bewag decided to offer only overflow storage heaters. ${ }^{28}$ As stated by the "Büro für Sonderaufgaben", these heaters were superior not only because they operated fully automatically but because they enabled a permanent and more constant use of heating power. The design of the storage water heater thus reflected the expectation that consumers would use hot water on a daily basis. Due to heat losses, even when only a small amount of water was tapped, a constant amount of off-peak power was used every night because neither water volume nor temperature could be manipulated. The use of the appliance was expected to be efficient when used everyday and thus to contribute to a more balanced electricity consumption.

Many consumers, however, followed a different routine in their personal hygiene. Taking a bath was a weekly event, usually performed on Saturdays. Thus consumers took the appliance off the grid during the week. In doing so, they could avoid the costs for heat losses when the appliance was not needed during the week. ${ }^{29}$ Representatives of the electricity industry complained that this use of the appliance did not contribute to a balanced load factor because it charged the off-peak power only during the weekend which was even recognizable as a 'bathing peak' in the load curves of the electricity industry. ${ }^{30}$

26 | Fritz Wallmüller: Der Elektrizitätszähler in Theorie und Praxis. Berlin: Drukkerei und Verlagsanstalt Noden GmbH, 1935, 1093-97.

27 | "Ausführungsbestimmungen für Miet-Heißwasserspeicher-Anlagen der BEWAG", 1931, Bewag-Archiv/Vattenfall Berlin, folder 5/52, 6.

28 | Jahrbuch der Verkehrsdirektion 1929, 45.

29 | Jahrbuch der Verkehrsdirektion 1929, 43.

30 | "Elektrische Koch- und Badeeinrichtungen einer neuzeitlichen Siedlung", in: AEG-Mitteilungen 5 (1930), 363-64. 


\section{Adjusting the Rental Service to New Challenges since the Energy Crisis of 1930}

Private households played a particularly important role as electricity storage via the installation of certain appliances, in particular storage water heaters, when the rental service was introduced. Bewag designed the rental service conditions first and foremost in order to balance peak loads. As a result of the international financial and economic crisis at the end of the 1920 s, however, it was in particular industrial energy consumption that decreased dramatically from 1930 till $1933 \cdot{ }^{31}$ During that period, Bewag shelved further plans to expand power plant capacities that it had initiated in 1926 . But since the extension and construction of new power plants had partly already been carried out, Bewag now faced an increasing amount of surplus energy capacities and at the same time decreasing electricity sales. $^{32}$ Hence, private households became even more attractive as promising energy consumers for the electricity industry. Utilities such as Bewag extended their advertising for residential electricity consumption. However, the goal now was no longer to encourage private households to use surplus electricity during specific periods, but to stimulate electricity consumption by any means, regardless of peak loads. ${ }^{33}$

Therefore, Bewag intensified their efforts to promote electric cooking and hot water heating in particular. The rental service for water heaters had already proven its worth for adjusting residential electricity consumption to the conditions of the energy market, depending on the provided appliances and their installation. First of all, Bewag reduced night-time power use to five Reichspfennig and supported every newly-installed heater with a financial subsidy of 15 Reichsmark in order to encourage its incorporation into private households. ${ }^{34}$ Now however, facing surplus capacities that could be consumed in private households, Bewag redesigned the rental

31 | Wolfgang Zängl: Deutschlands Strom. Die Politik der Elektrifizierung von 1866 bis heute. Frankfurt/Main: Campus, 1989, 120-75.

32 | Matschoß: 50 Jahre Berliner Elektrizitätswerke, 57-60.

33 | Herbert F. Müller: “Wirtschaftskrise und Stromwerbung”, in: Elektrizitätswirtschaft 31:8 (1932), 166; Berliner Städtische Elektrizitätswerke Akt.-Ges., ed.: Jahrbuch der Verkehrsdirektion 1931. Berlin, 1932, 43.

34 | "Direktionsrundschreiben 3/1932", 08.02.1932, Bewag-Archiv/Vattenfall Berlin, folder $5 / 52$. 
business to prevent consumers from switching off their appliance during the week and furthermore encouraged additional heating-up during the day. In doing so, Bewag counteracted consumers' intractable behaviour by installing more and more storage heaters with two or three outlets, one of which supplied the kitchen. ${ }^{35}$ Bewag expected a certain amount of hot water to be needed in the kitchen almost every day in the majority of households. Using appliances that served the bathroom as well as the kitchen, Bewag supposed, consumers would not take the appliance off the grid anymore. Despite more outlets, the size of the tank was not changed. Thus, the volume of water heated up during the night in the common 50 and 80 litre tanks was sufficient to supply, for instance, the hot water needed in the kitchen but not, in addition, the water for a hot bath in the evening. However, the modification in the appliance's design (i.e. the additional outlets) was supplemented by a transformation of the time switch. From now on, the exclusive restriction of heating-up periods to night-time hours was abandoned..$^{6}$ Water heaters could now be charged for several hours during daytime and if consumers used water both for preparing meals and personal hygiene during one day, the new appliance design even allowed additional heating-up during the day. With regard to Bewag's motivation of stimulating electricity consumption in general this was supposed to extend the time when the appliance consumed electricity. ${ }^{37}$ However, even additional daytime charging could not provide several bath fillings on one day. Hence it was hard to continue the family's bathing day, given that a fresh bathtub filling was required for each member of the family. Since at this time the habit of several persons bathing one after the other in the same bath water was widespread, the limited volume of water provided by storage water heaters probably even encouraged many users to keep this routine going. Actually, the design and installation of the appliance was more intended to make consumers abandon their 'bathing day' and have a bath for every single person on a different day. In that way, there would be an even amount of electricity consumption for hot water heating throughout the week, which would contribute to a more efficient utility

35 | Ihno Thiemens: “Wirtschaftliche Fragen bei der Vermietung von Heißwasserspeichern", in: Elektrizitätswirtschaft 3:8 (1932): 171.

36 | "Das Heißwasserspeicher Mietsystem der Bewag”, 1932, Bewag-Archiv/ Vattenfall Berlin, folder 5/52, 14.

37 | Thiemens: “Wirtschaftliche Fragen”, 171. 
capacity operation. However, this required reorganizing the bathing routines by using a 'bathing calendar'. This calendar - which, according to the electricity industry, could be found in quite a few households envisaged one bathing day per person during the week and was regarded as a practical answer to the existing technological constraints. ${ }^{38}$

However, the actual users of the rental service attached less importance to electric water heating in the kitchen, which could be provided in passing on the kitchen stove. Contrary to Bewag's initial assumption, bathroom storage heaters were the most appealing appliances for consumers because they did away with the laborious heating of water with coal. ${ }^{39}$ In particular the bathroom storage heaters of 80 litres were rented and installed and ever more frequently replaced by even larger heaters of 120 and 150 litres that were rented out since 1932. The number of rented heaters increased year by year and with it their volume. The average volume of rented heaters increased from 68 litres to 81 litres. ${ }^{40}$ This provides evidence for growing hot water consumption in private households since the introduction of the appliance. By enlarging the average storage size, Bewag enabled energy use that was more attuned to consumers' demands. Water heaters with larger volume could provide a larger amount of hot water in case of need. This indicates that some consumers did not reorganize their bathing routines but rather used the appliance when it was needed. For instance, they used the entire water volume provided by the appliance during one day in order to have a bathing day, but switched the appliance off completely the other day, when no hot water was needed. Since this conduct was still bemoaned by the electricity industry in 1960 , it seems to have been a common practice with storage water heaters. ${ }^{41}$

Bewag adjusted their rental service to the changed consumers' demands by supplementing the rental service with large-scale storage water heaters

38 | Theodor Stiebel: “Der Badekalender. Ein Betrachtung zur Kapazität von Nachtstromspeichern im Hinblick auf die Kopfzahl größerer Familien”, in: Elektrizität 3:3 (1953), 57-58.

39 | Thiemens: “Wirtschaftliche Fragen”, 168.

40 | Berliner Städtische Elektrizitätswerke Akt.-Ges., ed. Jahrbuch der Verkehrsdirektion 1933. Berlin, 1934, 40.

41 | P. Borstelmann: "Elektrische Heißwasserbereitung im Haushalt", in: Elektrizität 10:11 (1960), 243. 
with volumes of 120 and 150 litres. ${ }^{42}$ This did not exactly correspond to their initial marketing strategies. But with the partial adjustment of the rental service to the consumers' routines of personal hygiene, Bewag succeeded in promoting an appliance that was at first neither common nor regarded as attractive but was now used increasingly often. From 1,305 rented storage water heaters in 1931, the number of rented heaters grew up to 7,454 water heaters in $1935 \cdot{ }^{43}$

Bewag continued its marketing strategies to stimulate the usage of certain household appliances during the Nazi period. But in 1941, the company terminated the rental and hire-purchase business for household appliances. ${ }^{44}$ This was due to restrictions and, later, even a ban on the production of household appliances in the context of the wartime economy that marks a break in the history of consumption. ${ }^{45}$ At the same time as Bewag abandoned its hire-purchase and rental service, the first upswing of household mechanization and electrification ended. It had led to a more widespread adoption of consumer goods such as electrical water heaters for which there had formerly been little demand. This period, however, is not primarily significant in terms of the quantity of household appliances that found its way into private households, but rather with regard to evolving consumer wishes and the emergence of a material infrastructure that helped to popularize electric household appliances as affordable consumer goods. ${ }^{46}$

However, it was not before the 1950 s when consumption of durable goods like household appliances became more widespread. Based on new social, political and economical premises, the housing situation and private household incomes improved. This marks the transition to a new

42 | Thiemens: "Wirtschaftliche Fragen”, 169.

43 | E. Albrecht: "Einige Zahlen aus unserer BEWAG”, in: Der Stromkreis. Werkzeitung der Berliner Kraft- und Licht (Bewag)-Aktiengesellschaft 2:6/8 (1935): 98.

44 | Herber Baddack: “Elektrissima - Ein Berliner Begriff”, in: Elektrizität 9:5 (1959), 99.

45 | Heßler: 'Mrs. Modern Woman', 19.

46 | Martina Heßler: “Visionen des Überflusses. Entwürfe künftiger Massenkonsumgesellschaften im 20. Jahrhundert”, in: Hartmut Berghoff/Jakob Vogel, eds. Wirtschaftsgeschichte als Kulturgeschichte. Dimensionen eines Perspektivwechsels. Frankfurt/Main: Campus, 2004, 455-80. 
consumption regime that is based on the Fordist consumption pattern. ${ }^{47}$ Appliances became mass consumer goods and lost their character as a social distinction of a consumer elite. ${ }^{48}$

\section{Steering Consumers away from the Load Peak IN THE 1950S}

In the course of the economic recovery and reconstruction, Bewag did not hesitate to boost electricity consumption in private households. In 1949, the company took up the hire-purchase business and resumed the rental business for storage water heaters in 1953. For a short period, they even expanded the service to rent out electric stoves. ${ }^{49}$ During the 'economic miracle' an increasing number of gadgets and appliances found their way into private households and thus opened a new era of residential consumption and energy use. Now, energy suppliers like Bewag faced new challenges. The growing electricity consumption of an increasing number and diversity of appliances that were mostly used during the day produced inefficient peak loads. ${ }^{\circ}$ Due to the acceleration of household electrification it was henceforth necessary to balance the intensive residential peak loads..$^{1}$

Therefore, those appliances consuming off-peak power again became more attractive as potential 'electricity storage'. Night-time electricity usage was still considered an important and expandable factor to balance peak capacities and storage water heaters were regarded as the most appropriate appliance to reach this target. ${ }^{2}$ Simultaneously, electricity usage for water heating was regarded as hugely expandable during the 1950 os because it was used in fewer than 10 percent of private households and thus was in fierce

47 | de Grazia: "Changing Consumption Regimes in Europe", 78-83.

48 | Arne Andersen: "Das 50er-Jahre Syndrom - Umweltfragen in der Demokratisierung des Technikkonsums", in: Technikgeschichte 65:4 (1998), 329-44.

49 | Cf. the contribution of Sophie Gerber in this volume.

50 | Heinz Weidauer Obering: “Stromabsatzwerbung”, in: Elektrizität 4:8 (1954), 232.

51 | Ludwig Koch: "Die Haushaltsgeräte-Absatzpolitik in Elektrizitäts-Versorgungsunternehmen" (Unpublished Ph.D. diss., Ludwig-Maximilians-Universität München, 1957), 110-111.

52 | Koch: “Die Haushaltsgeräte-Absatzpolitik”, 110, 151. 
competition to coal and gas usage for water heating. ${ }^{53}$ In 1950, 78.3 percent of all dwellings in Germany did not have a bathroom or a shower at all. Even in 1957, 72.9 percent of private households were not even equipped with hot water supply. ${ }^{54}$ Beginning with the first housing law in 1950 and complemented by other construction and renovation programs aimed at improving the inadequate housing situation, it became increasingly important for the utilities to literally get a foot in the door, especially in order to be able to compete with the gas industry. ${ }^{55}$ Just like other utilities ${ }^{56}$, Bewag expanded their rental business to the housebuilding market and supplied newly-built housing estates and landlords with their rental storage water heaters in order to set the course for the fully electrified household of the future. ${ }^{57}$

Seeing new challenges on the energy market, Bewag aligned their rental service to the determining factors of the electricity industry and developments of the appliances. The company rented out 80 litres bathroom water heaters and 15 litre boilers for the kitchen..$^{8}$ Both were configured with a second electric circuit. Thus, the appliance charged off-peak power during the night but could be switched on additionally during the day. The most crucial change to the former rental service was the complete abandonment of the technically based restriction, the relay circuit controlled by a time switch, in favour of a simple price-based regulation by providing special tariffs for night-time charge. Bewag had

53 | Jean Schwarz: "Erfahrungen in der Heißwassergerätewerbung nach Einführung der Typenbeschränkung”, in: Elektrizität 9:9 (1959), 256.

54 | Statistisches Bundesamt: 50 Jahre Wohnen in Deutschland. Ergebnisse aus Gebäude- und Wohnungszählungen, Stichproben, Mikrozensus-Ergänzungserhebungen und Bautätigkeitsstatistiken. Stuttgart: Statistisches Bundesamt, 2000, 86-87.

55 | Wilhelm Strahringer: "Tradition, Fortschritt und Freiheit im Energiebereich des Haushalts", in: Elektrizität 9:6 (1959), 121.

56| "Viele Wege führen zur vollelektrischen Siedlung", in: Elektrizität 3:2 (1953), 30-31.

57 | "Betrifft Herd- und Speicher Mietaktion", 24.06.1953, Bewag-Archiv/Vattenfall Berlin, folder 5/52, 5; "Anlage zum Bericht über die Sonderaktion im Mietspeichergeschäft”, 1958, Bewag-Archiv/Vattenfall Berlin, folder 5/52.

58 | "Aktennotiz: Betrifft Herd- und Speicher-Leihaktion”, 30.10.1953, BewagArchiv/Vattenfall Berlin, folder 5/52. 
already considered abandoning the relay circuit in 1938, shortly before the rental service had been interrupted. Balancing load peaks was not the main concern of the utility at this time. Bewag had come to the conclusion that this step was more inefficient in terms of their power plant utilization, but that it could advance energy sales. ${ }^{59}$ In the 1950s, giving up the time switch not only reduced installation costs for Bewag, but was also intended to make the rental business more suited to new consumption habits and new expectations of convenience. Even though the electricity industry continued to prefer the use of night-time power, they also acknowledged the fact that lifestyles were changing. This became recognizable for instance in a gradually increasing use of hot water and the expectation to have this demand satisfied whenever it was needed. ${ }^{60}$ Therefore, all modern storage water heaters were now fitted with a second electric circuit. ${ }^{61}$ In contrast, the former very limited volume of warm water that had called for the use of a family-bathing calendar was regarded more and more inappropriate. ${ }^{62}$

Meanwhile, in addition to new, modernized appliances like the continuous-flow water heater, appliances had not only been technologically improved but had also become cheaper. Although these heaters consumed mainly peak electricity that was usually more expensive, these appliances became more and more popular in Germany from the second half of the 1950 s onwards. ${ }^{6}$ Since Bewag was particularly interested in introducing more off-peak consuming appliances to private households, they did not promote continuous-flow heaters. ${ }^{64}$ On the contrary, a special tariff was designed to make customers use primarily night-time power for water heating. However, in 1956, Bewag's management was unsatisfied with the development of the rental service. According to an internal discussion on the efficiency of the rental service, the financial incentive had failed to adapt consumers' use of the appliance to the determining factors of

59 | Thiemens: "Die Wirtschaftlichkeit des vollelektrischen Haushaltes”, 795.

60 |W. Petrus: "Einfluß der Heißwasserbereitung auf die Verteilungsnetze", in: Elektrizität 8:2 (1958), 32-34.

61 | Hans Oeljeschlager: "Zweikreisspeicher. Ihre Möglichkeiten und Grenzen”, in: Elektrizität 3:3 (1953), 53.

62 | Stiebel: “Der Badekalender”, 57-58.

63 | Petrus: "Einfluß der Heißwasserbereitung”, 33.

64 | "Bedingungen des Elektrissima-Teilzahlungssystems“, November 1956, Bewag-Archiv/Vattenfall Berlin, folder 5/53, 4. 
the energy market. On the contrary, storage water heaters with a second electric circuit were heated up increasingly often during the day. Their electricity consumption coincided with the peaks of other energy-intensive appliances in the household. ${ }^{65}$ Thus, the households lost their function as 'storage' for off-peak power that was to compensate residential and industrial peaks.

The management bewailed the lack of a technical element that controlled heating-up times in order to regulate consumption more strictly. They discussed developing a control equipment for storage water heaters that was expected to "steer consumers away from the load peak." ${ }^{66}$ Rents for water heaters without this control equipment were intended to be more expensive. However, this technology-based solution was never realized. Instead, Bewag's management regarded the rental service more and more as a financial burden. Its costs were felt to progressively exceede the revenues from the renters and the management considered giving up the rental business altogether. ${ }^{67}$

Nevertheless, Bewag continued the rental service. Due to the political division of the city of Berlin, the western part of the company had become an island with regard to energy production and supply. The separation of the electricity supply network called for an independent electricity provision in West Berlin. Furthermore, in densely populated West Berlin, private households' energy consumption constituted the lion's share in Bewag's supply area. Thus, the load compensation by off-peak power usage was an important economic factor for the utility. As Bewag's annual report for the years 1957-1958 shows, the utility company anticipated a growing challenge of balancing the peak loads of the - for the most part - daytime consumers that were expected to increase. The report stated that consequently the advertisement of night-time usage in private households was to be treated with priority. ${ }^{68}$ Therefore, Bewag's management decided to keep the rental service for the time being.

65 | "Bedingungen des Elektrissima-Teilzahlungssystems", 3-4.

66 | [Original: "Wegsteuern aus der Spitze”, transl. N.L.]. "Bedingungen des Elektrissima-Teilzahlungssystems", 3-4.

67 | "Bericht über eine Sonderaktion im Mietspeichergeschäft", 20.08.1958, Bewag-Archiv/Vattenfall Berlin, folder 5/52, 1.

68| “Umschau: In Berlin bestimmt der Haushalt", in: Elektrizität 9:1 (1959), 19-20. 


\section{The Barrel ON the Wall}

Nevertheless, the attempt of steering consumers' routines of hot water consumption via the rental business according to the utilities' interest in a balanced load factor of their power plants turned out to be an unsuccessful enterprise. In 1958, Bewag doubted that the rental business would pay off in its existing way. For this reason, the utility offered rental heaters for sale and raised the rent for continuing contracts up to 50 percent. $^{69}$

At least 59 percent of Bewag's customers then purchased their water heaters. Besides, Bewag's management had to realize that only an insignificant number of storage water heaters were sold in shops. Furthermore, 50 percent of the remaining consumers reacted to the rent increase by returning their appliance to Bewag. At this time many of the rental service's appliances were technologically outdated. ${ }^{70}$ Some of them had been rented out since the $1930 . .^{71}$ Now, less chunky storage heaters, continuous flow heaters and appliances that combined the night-time charging with additional continuous flow heating during the day were upto-date. Hence, consumers lost interest in the rental service and its storage heaters. But adjusting the rental service to state-of-the-art appliances would have required additional capital investment in a business that already had turned out to be a financial burden for the company. ${ }^{72}$ Not willing to invest additional money, Bewag restricted its rental service to the existing heaters in 1959. From now on, they only re-rented appliances that were returned. Although the rental service remained a cheap possibility to install hot water supply in a dwelling, consumers' interest in the rental service diminished. The appliances were technologically outdated and could no longer meet rising consumer expectations. ${ }^{73}$

69 | "Mitteilung”, 10.02.1958, Bewag-Archiv/Vattenfall Berlin, folder 5/52.

70 | “Aktenvermerk. Betreff: Mietspeicher”, 27.07.1959, Bewag-Archiv/Vattenfall Berlin, folder 5/52.

71 | "Betr.: Stellungnahme zu den Kalkulationen von SL über das Heißwassspeicher-Mietgeschäft”, 13.08.1959, Bewag-Archiv/Vattenfall Berlin, folder 5/52.

72 | "Aktenvermerk. Betreff: Mietspeicher".

73 | "Rundschreiben Nr. 1-1959/60", 22.10.1959, Bewag-Archiv/Vattenfall Berlin, folder $5 / 53$. 
So the storage water heaters became a "barrel on the wall."74 Neither did architects or house builders want them, primarily for aesthetic reasons, nor were they preferred by consumers, whose water needs had increased together with their expectations of convenience, of having hot water available in any required amount at any time of the day.

The growing amount of electricity consumption for hot water heating sparked a discussion on the efficiency of night-time charging in general. As an investigation on electricity usage in a fully electrified new housing estate in Hamburg indicates, the night-time charging produced a peak that was partly higher than the daytime electricity consumption, due to the growing demand for hot water. Because of the still very common bathing day, this peak even intensified on weekends. This was a very unfavourable peak load because it would have required additional power plant capacities. ${ }^{75}$

Instead of steering consumers away from the load peak by a specific appliance design, the electricity industry redesigned the appliance in accordance with consumers' preferences. As the electricity industry stated even in 1953, appliances and tariffs were adjusted increasingly to consumers' progressing expectations of convenience and hygiene:

"In the past it was the utility company that defined which appliance should be used by its customers, by means of a more balanced capacity utilization. For this reason the utilities introduced the storage water heater. But the latest trends lead to appliances that are first and foremost adjusted to the needs of the consumers." 76

With regard to these changed needs the notion of utilising the household as storage that uses electricity for water heating only during defined periods became obsolete. Instead of focusing on steering consumers in order to make capacity utilization more efficient, the electricity industry discussed

74 | [Original: "Walze an der Wand", transl. N.L.]. Borstelmann: "Elektrische Heißwasserbereitung im Haushalt”, 244.

75 | E. Moslener: "Erfahrungen mit vollelektrifizierten Wohnbauten in Hamburg", in: Elektrizität 3:2 (1953), 20.

76 | [transl. N.L.] "Zur Entwicklung der elektrischen Heißwasserbereitung", in: Elektrizität. 3:3 (1953), 52. 
whether it would be more promising to stimulate electricity consumption in general and to balance peaks by the simple diversity of appliances. ${ }^{77}$

The development of the rental service can be interpreted as a negotiation process between the utility company and its customers, the outcome of which were technologically developed appliances, adjusted tariffs and last but not least the extension of the power network. Thus, Bewag decided to invest no further capital into the rental business for an appliance that had become a barrel on the wall. The rising needs of consumers were rather used as a legitimization to build up network capacities. Bewag's management determined to put more money into the expansion of the electric power network to meet the demands of appliances with a higher load factor such as continuous flow water heaters that could satisfy the needs of the prospective consumers. ${ }^{78}$ Since the electricity industry already predicted a growing residential electricity utilization, this development was intended to pioneer the increasing usage of bigger, more energy-intensive appliances. ${ }^{79}$

Corresponding to these new targets of the Bewag, they also reformulated their tariff system in 1960, promoting electricity consumption following the principle "who consumes more, pays less." 80 The utilization of appliances that consumed off-peak power was still advertised by a cheaper night-time tariff. However, using a water heater during the day became relatively cheap as well. Since off-peak power usage for space heating became more popular during the 1960 s and $70 s^{81}$, water heaters became less important as night-time power consumers. In 1975, Bewag eventually terminated the extant rental agreements. Hirers could either buy their formerly rented appliance or Bewag uninstalled it. ${ }^{82}$

77 | "Zur Entwicklung der elektrischen Heißwasserbereitung”, 48.

78 | "Aktenvermerk. Betreff: Mietspeicher".

79 | "Stromverbrauchsentwicklung", in: Elektrizitätswirtschaft 54:11 (1955), 384-85.

80 | Berliner Kraft-und-Licht-(Bewag)-Aktiengesellschaft: 100 Jahre Strom, n.p.

81 | “Nachtstrom-Knappheit”, Der Spiegel 38 (1973), 97.

82 | "Bewag verleiht keine Boiler mehr”, in: Der Tagesspiegel, 24.01.1975 [in:

“Presseauswertung Nr. 242", Bewag-Archiv/Vattenfall Berlin, folder 5/52]. 


\section{Epilogue: A Trojan Horse in the Bathroom}

Due to their rental service, Bewag succeeded in placing storage water heaters in private households. The company had precise expectations about appropriate hot water consumption in private households as a means to make power plant utilization more efficient. The design of the appliance was as important in this effort to influence the manner of consumption as was the ensemble of meter, heater and time switch. With the interplay of these elements, certain ways of using the appliance and consuming hot water were inscribed into the appliance. ${ }^{83}$ By the regulation of heating-up time and water volume, the rental service defined appropriate routines of personal hygiene. The suitable usage of this ensemble called for consumers that turned every day into a potential bathing day. ${ }^{84}$ Consumers partly refrained from adjusting their routines to the appliance but they nevertheless acted as co-producers of the technology. Thus, the modification of the rental service, as it was adjusted to consumers' behaviour and their changing needs, provides clear evidence for consumers' crucial role in the development of an appliance. This becomes particularly apparent with Bewag's attempts to manage residential electricity consumption during the second period of the rental service. Now technological and tariff-based solutions that were supposed to manage consumption according to new challenges of the energy market fell short of a changed consumption regime. Along with higher incomes and improved housing standards, consumption was no longer characterised by constraints but by abundance. ${ }^{85}$ Just as appliances became affordable as mass consumer goods, the mentality towards energy consumption modified from a regime of scarcity to a regime of abundance.

Along with, in relation to the average income, cheap energy and automated appliances to provide hot water, routines of personal hygiene changed. The daily hot shower became slowly but surely indispensable in daily routines and expectations regarding length and temperature became gradually higher. ${ }^{86}$ Simultaneously, the load factor of hot water

83 | Akrich: "The De-Scription of Technical Objects".

84 | Cf. a similar conflict between users' bathing routines and building experts on the usage of electric storage water heaters in Heßler: 'Mrs Modern Woman', 293-302.

85 | de Grazia: "Changing Consumption Regimes in Europe", 83.

86 | Shove: Comfort, Cleanliness and Convenience, 79-116. 
heating appliances had progressively increased. Modern appliances provided hot water almost instantaneously whenever it was needed and influenced expectations of convenience. Due to growing hot water usage, the charging periods of these appliances during daytime and night-time hours intensified as well. Bewag was no longer able to meet the rising standards of convenience and hygiene with their rental appliances and therefore finally adjusted their marketing policy to changing patterns of consumption.

Eventually, increasing demand for hot water did not only contribute to private households' daytime peak loads. Electricity consumption for water heating during night-time and daytime hours and supplementary space heating turned out to exceed the available off-peak capacity of power stations. ${ }^{87}$ The appliances consuming night-time power such as storage water heaters that had been intended to increase electricity sales by using surplus off-peak electricity without necessitating additional bulk electricity systems became a Trojan Horse. Now, private households that had initially been discovered as potential storage of surplus energy became a reason for the electricity industry to build up power plant capacities. ${ }^{88}$

The focus on hot water heating as a negotiation process between a utility company and its consumers reveals how a technology is shaped by the interplay of engineers, manufacturers and consumers. Engineers or manufactures inscribed certain ideas of energy consumption into the appliance but the integration of the appliance in its environment as a consumer good reshaped the initial concept of energy utilization.

The concept of using private households as 'storage' for electricity is again emphasized in conjunction with today's attempts to feed in more regenerative energies to the power network and to design electricity consumption more efficiently. ${ }^{8}$ U Using smart meters, energy consumption is supposed to be easily adjustable to the energy disposable by wind turbines and photovoltaic arrays. This concept is also based on the notion that private households are more flexible consumers than the industry.

87 | "Nachtstrom-Knappheit", 97.

88 | Zängl: Deutschlands Strom, 288.

89 | Inge Røpke/Sophie Nyborg: "Energy Impacts of the Smart Home - Conflicting Visions", in: Energy Efficiency First. The Foundation of a Low-Carbon Society, ECEE 2011 Summer Study; 6-11 June 2011; proceedings. Stockholm: European Council for an Energy Efficient Economy, 2011, 1849-1860. 
Using certain technologies, like the smart meter, residential consumption can be partly adjusted to the load of the power network. Therefore, new challenges arise to mediate the appropriate usage of the technology to private households. Once introduced, smart meters control the turning-on of several appliances according to the load factor of the power network. Thus, the technology can contribute to residential electricity savings.

However, experts warn that this technology could become a Trojan Horse as well. For instance, the development of the smart grid may even intensify the trend of integrating an increasing number of information and communication technologies into private households. Therefore, the potential of the smart home to save energy could even contribute to increasing residential electricity consumption..$^{\circ}$

Similar to the off-peak power promotion that eventually fell short of contributing to energy supply efficiency, the concept of the smart meter could fail if consumers' expectations on convenience are not taken into account accurately. It becomes evident that a simple technology-based solution is inadequate for governing consumption. Rather, consumption patterns have to be regarded as socially constructed and embedded in a complex network of cultural meanings.

\section{References}

\section{Primary Sources}

Bewag-Archiv/Vattenfall, Berlin

folder 5/52, "Heißwasserspeicher"

folder 5/53 "Elektrissima E3"

folder 5/51 "Stromrechnungen 1925-1960"

AEG-Mitteilungen, 1930-1931

Der Spiegel, 1973

Der Stromkreis. Werkzeitung der Berliner Kraft- und Licht (Bewag)-Aktiengesellschaft, 1935

Elektrizität. Zeitschrift für Abnehmerberatung. Organ der Hauptberatungsstelle für Elektrizitätsanwendung (HEA), 1952-1960

90 | Røpke: “Energy Impacts of the Smart Home”, 1857-58. 
Elektrizitätswirtschaft. Mitteilungen der Vereinigung der Elektrizitätswerke, 1926-1955

Berliner Städtische Elektrizitätswerke Akt.-Ges., ed. Jahrbuch der Verkehrsdirektion 1929-1933, Berlin: 1930-1934.

Koch, Ludwig. "Die Haushaltsgeräte-Absatzpolitik in Elektrizitäts-Versorgungsunternehmen” (Unpublished Ph.D. diss., Ludwig-MaximiliansUniversität München, 1957).

C. Matschoß/E. Schulz/A. Th. Groß, eds. 50 Jahre Berliner Elektrizitätswerke. 1884-1934 (=Veröffentlichungen der Bewag II. Vol 14). Berlin: VDIVerlag, 1934 .

Wallmüller, Fritz. Der Elektrizitätszähler in Theorie und Praxis. Berlin: Druckerei und Verlagsanstalt Noden G.m.b.H., 1935.

\section{Secondary Sources}

Akrich, Madeleine. "The De-Scription of Technical Objects”, in: Wiebe E. Bijker/John Law, eds. Shaping Technology/Building Society: Studies in Sociotechnical Change. Cambridge, MA: MIT Press, 1992, 205-24.

Andersen, Arne. "Das 5oer-Jahre Syndrom - Umweltfragen in der Demokratisierung des Technikkonsums”, in: Technikgeschichte 65:4 (1998), 329-44.

Berliner Kraft-und-Licht-(Bewag)-Aktiengesellschaft, ed. 100 Jahre Strom für Berlin. Ein Streifzug durch unsere Geschichte in Wort und Bild, 18841984. Berlin: Bewag, 1984.

de Grazia, Victoria. "Changing Consumption Regimes in Europe, 19301970. Comparative Perspectives on the Distribution Problem”, in: Susan Strasser/Charles McGovern/Matthias Judt, eds. Getting and Spending. European and American Consumer Societies in the Twentieth Century. Cambridge: Cambridge University Press, 1998, 59-83.

Heßler, Martina. “Die Einführung elektrischer Haushaltsgeräte in der Zwischenkriegszeit. Der Angebotspush der Produzenten und die Reaktion der KonsumentInnen”, in: Technikgeschichte 65:4 (1998), 297-311.

-. 'Mrs. Modern Woman'. Zur Sozial- und Kulturgeschichte der Haushaltstechnisierung. Frankfurt/Main: Campus, 2001.

- . "Visionen des Überflusses. Entwürfe künftiger Massenkonsumgesellschaften im 20. Jahrhundert", in: Hartmut Berghoff/Jakob Vogel, eds. Wirtschaftsgeschichte als Kulturgeschichte. Dimensionen eines Perspektivwechsels. Frankfurt/Main: Campus, 2004, 455-80. 
Hughes, Thomas P. Networks of Power. Electrification in Western Society, 1880-1930. Baltimore, MD: Johns Hopkins University Press, 1983.

Langguth, Frauke. "Zur Geschichte der Elektrifizierung der privaten Haushalte. Die Absatzpolitik der Bewag gegenüber den privaten Haushalten in Berlin während der Weimarer Republik" (Unpublished Master's thesis, TU Berlin, 1988).

-. “'Elektrizität in jedem Gerät'. Die Elektrifizierung der privaten Haushalte am Beispiel Berlins”, in: Barbara Orland, ed. Haushalts-Träume. Ein Jahrhundert Technisierung und Rationalisierung im Haushalt. Königstein im Taunus: Langewiesche, 1990, 93-102.

Pursell, Caroll. "Domesticating Modernity: The Electrical Association for Women, 1924-1986", in: The British Journal for the History of Science 32:1 (1999), 47-67.

Røpke, Inge/Nyborg, Sophie. "Energy Impacts of the Smart Home - Conflicting Visions", in: Energy Efficiency First. The Foundation of a LowCarbon Society. ECEE 2011 Summer Study; 6-11 June 2011; proceedings. Stockholm: European Council for an Energy Efficient Economy, 2011, 1849-6o.

Shove, Elizabeth. Comfort, Cleanliness and Convenience. The Social Organization of Normality. Oxford: Berg, 2003.

Stadelmann, Christian. "Strom für Alle. Schritte der Elektrifizierung und Geräteausstattung des Haushalts bis zur Mitte des 20. Jahrhunderts", in: Blätter für Technikgeschichte 66/67 (2004/05), 117-41.

Statistisches Bundesamt. 50 Jahre Wohnen in Deutschland. Ergebnisse aus Gebäude- und Wohnungszählungen, Stichproben, Mikrozensus-Ergänzungserhebungen und Bautätigkeitsstatistiken. Stuttgart: Statistisches Bundesamt, 2000.

Tetzlaff, Sven. “'Laß mich hinein...!' Die Eroberung der Haushalte durch die Elektrizitätswirtschaft”, in: Ursula Schneider/Detlef Stender, eds. Das Paradies kommt wieder. Zur Kulturgeschichte und Ökologie von Herd, Kühlschrank und Waschmaschine. Hamburg: VSA Verlag, 1995, 10-25.

Zachmann, Karin. “Technik, Konsum und Geschlecht - Nutzer/innen als Akteur/innen in Technisierungsprozessen”, in: Petra Lucht/Tanja Paulitz, eds. Recodierungen des Wissens. Stand und Perspektiven der Geschlechterforschung in Naturwissenschaft und Technik. Frankfurt/Main: Campus, 2008, 69-86.

Zängl, Wolfgang. Deutschlands Strom. Die Politik der Elektrifizierung von 1866 bis heute. Frankfurt/Main: Campus, 1989. 


\section{Saving Energy by Shifting Clocks?}

\section{Energy Policy and the Introduction of Daylight Saving Time in East and West Germany}

\section{Mathias Mutz}

In his essay Energy and Equity (1974), Ivan Illich gives an interesting contemporary starting point for interpreting the social role of energy in the last third of the $20^{\text {th }}$ century. He describes the growing dependency of modern societies on their energy supply:

"High quanta of energy degrade social relations just as inevitably as they destroy the physical milieu. [...] The energy policies adopted during the current decade will determine the range and character of social relationships a society will be able to enjoy by the year 2000. A low-energy policy allows for a wide choice of lifestyles and cultures. If, on the other hand, a society opts for high energy consumption, its social relations must be dictated by technocracy and will be equally degrading whether labeled capitalist or socialist. [...] Even if nonpolluting power were feasible and abundant, the use of energy on a massive scale acts on society like a drug that is physically harmless but psychically enslaving." ${ }^{1}$

In uttering this opinion, Illich was a maverick. But until today most people would interpret the implementation of Daylight Saving Time (DST) ${ }^{2}$ in

1 | Originally published as Ivan Illich: Energy and Equity. London: Calder, 1974. See download version: http://clevercycles.com/energy_and_equity, Accessed: 15.07.2011.

2 | This paper uses the American English expression Daylight Saving Time instead of the British English Summertime, although the latter is closer to the German Sommerzeit. Both terms imply misleading or biased connotations; Daylight 
his spirit. Indeed, changing the clock twice a year has become one of the most widespread rituals of western industrial societies. Standard time is advanced in the summer months for one hour in order to increase the hours with daylight in the evening. In Germany, the scheme has been in constant use since 1980, when East and West Germany introduced it jointly. Looking at the history of daylight saving throughout the $20^{\text {th }}$ century it could be easily described as a strategy of 'social engineering,' a scientific approach to achieve efficiency and coherence by arranging and channeling environmental and social forces. ${ }^{3}$ Hence, it is not only a farreaching intrusion into everyday life, but also a bureaucratic sanction to redistribute power over energy according to specific interests.

But is the story really that simple? On closer inspection, it becomes obvious that there is a lack of clarity about why DST was introduced. It is a common misperception that this was first and foremost an energy saving measure. The corresponding Time Act (Gesetz über die Zeitbestimmung) does not speak of energy saving at all, but of "a better usage of daylight" and "adjustment of time measuring to neighboring states." 4 Public records and contemporary publications show that the West German government expected a marginal energy effect - less than o.1 percent of total energy demand. In 1978, the conservative politician Werner Broll stated in parliament: "It is not a question of energy savings [...]. It is - to use a term from popular sociology - about improving the quality of life." 5

Saving Time, however, seems more accurate and definable. My thanks go to Ingo Köhler, Laura Rischbieter, Samantha Taber, and the participants and organizers of the Munich workshop for their help in improving the paper.

3 | Cf. John Alexander/Joachim K. H. Schmidt: "Social Engineering: Genealogy of a Concept”, in: Adam Podgórecki/Jon Alexander/Rob Shields, eds. Social Engineering. Ottawa: Carleton University Press, 1996, 1-19; Thomas Etzemüller: "Social engineering als Verhaltenslehre des kühlen Kopfes. Eine einleitende Skizze", in: Thomas Etzemüller, ed. Die Ordnung der Moderne. Social Engineering im 20. Jahrhundert. Bielefeld: transcript, 2009, 11-40.

4 | "Gesetz über die Zeitbestimmung”, 25.07.1978, in: Bundesgesetzblatt, 31.07.1978, part I, 1110-11. All citations originally in German were translated by the author.

5 | Deutscher Bundestag: Stenographische Berichte der Verhandlungen des Deutschen Bundestages, Bonn 06.06.1978, 8015. 
With this in mind, why is the idea of daylight saving time as energy saving time still so popular today? What role did energy play in the debates of the 1970s? And what does this tell us about the societal role of energy, especially in German society "after the boom"6, i.e. after the end of the 'economic miracle'? How does it relate to Illich's idea of human 'energy addiction'? An analysis of political decision-making shows that the discussion was closely linked to the 'German Question.' The fear of a new time border through Germany and Berlin was responsible for a significant delay in implementing DST. While legislation for it had been prepared in Bonn as early as 1976, East Berlin's reluctance led to a substantial delay. From an energy perspective, the dimension of Cold War politics might seem distracting. On the other hand, this provides a unique opportunity to compare two interlinked debates in two closely related societies and their different political systems.

To decode the social meaning and interpretation of DST and analyze its function within the energy discourse, this paper conducts four steps. First, it highlights the traditional link between DST and energy shortage, referring to experiences from before 1970. Second, it discusses the energy argumentation concerning DST in both East and West Germany. Third, it retraces the political decision-making process with a special focus on the interplay between East Berlin and Bonn. Fourth, it looks into the material and symbolic significance of DST in relation to energy and energy saving. This approach aims to take into account both historical and structural particularities of the case studies. While there are a few historic accounts of DST in the United States, literature on Germany and Europe is scarce. ${ }^{7}$ But records from the responsible public institutions as well as contemporary media reports provide substantial insight into the constellation of interests and argumentation.

6 | Anselm Doering-Manteuffel/Lutz Raphael: Nach dem Boom. Perspektiven auf die Zeitgeschichte seit 1970. Göttingen: Vandenhoeck \& Ruprecht, 2008.

7 | Cf. David Prerau: Seize the Daylight. The Curious and Contentious Story of Daylight Saving Time. New York: Thunder's Mouth Press, 2005; Michael Downing: Spring Forward. The Annual Madness of Daylight Saving Time. Berkeley, CA: Counterpoint, 2009; Ian R. Bartky: One Time Fits All. The Campaigns for Global Uniformity. Stanford, CA: Stanford University Press, 2007, 161-99; for Germany Dirk Schindelbeck: “Wem die Stunde schlägt”, in: Damals. Das Magazin für Geschichte und Kultur 32:4 (2000), 6-9. 


\section{The History of DST as a History of Energy Shortages}

It is little known that the German Empire introduced DST for the first time in 1916 - a world premiere provoked by World War I and its resource shortages. A few years earlier, the contractor William Willett had popularized the idea of shifting clocks in summer in the United Kingdom, but between 1909 and 1911 the parliament in London rejected several private bills to introduce DST. ${ }^{8}$ Then, starting on April 30, 1916, the German Federal Council (Bundesrat) decided to introduce DST, because of the "necessity of using heating and lighting materials economically", and the UK followed its example three weeks later. ${ }^{9}$ Most other war participants followed suit, including the United States in 1918. German authorities later estimated annual savings of 250,000 tons of coal. Against the will of the new German government, the National Convention (Nationalversammlung) abolished the DST scheme in 1919, while Britain and France stayed on DST in the interwar years. Especially agrarian interest groups and shift workers opposed the new time rule, as it interfered with their daily routines..$^{10} \mathrm{DST}$ was reintroduced in April 1940, after the beginning of World War II. It remained in place during the winter months in 1940/41 and 1941/42. After the war, the occupying powers continued daylight saving, but directly after their founding, both German states stopped changing the clocks. For a long time DST was a marginal topic - apart from isolated petitions of individual

8 | William Willett: The Waste of Daylight. London: Author, 1907. Sometimes the concept is attributed to Benjamin Franklin, but he propagated a change of human behavior to make the best use of daylight, not changing clocks. Cf. Benjamin Franklin: "To the Authors of The Journal of Paris" (1784), in: Nathan G. Goodman, ed. The Ingenious Dr. Franklin. Selected Scientific Letters. Philadelphia: University of Pennsylvania Press, 1931, 17-22.

9 | "Staatssekretär des Innern to Staatssekretär des Reichs-Postamts", Berlin 24.03.1916, in: Bundesarchiv (Federal Archive, BArch,), R 4701, no. 207. For other countries, cf. Prerau: Seize the Daylight, 84-94.

10 | "Reichsminister des Innern to Reichswirtschaftsrat", Berlin 10.03.1926, in: BArch, R 401, no. 727; “Schreiben Reichsverkehrsminister to Reichsminister des Innern”, Berlin 27.11.1939, in: BArch, R 3101, no.10361. 
citizens or interest groups like the German Sports Association (DSV) and the ADAC automobile club. ${ }^{11}$

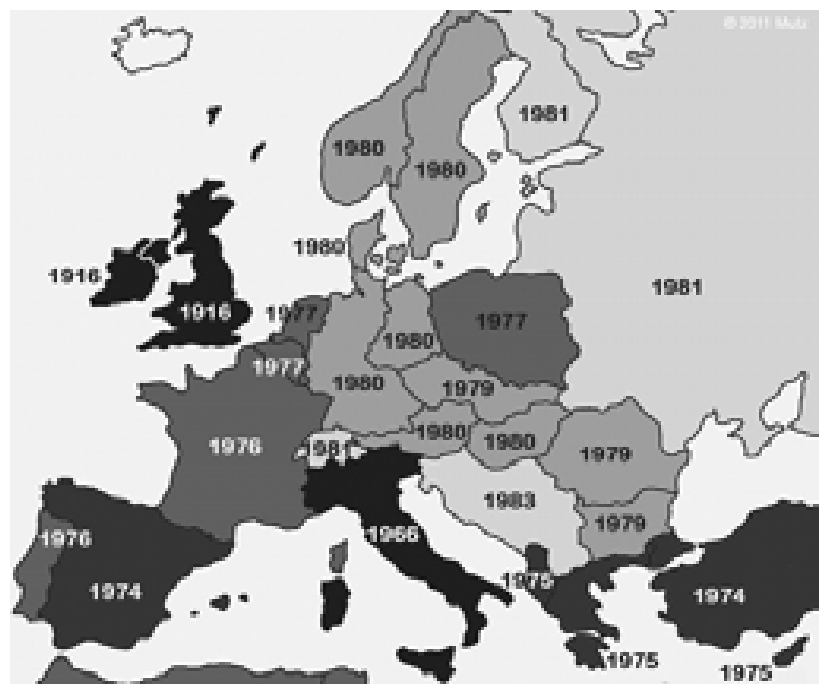

Figure 1: Introduction Dates of DST in Postwar Europe.

In Germany, DST remained a wartime action. It had always been advocated with energy saving arguments and used as war propaganda, even though its success was sometimes questioned within the state apparatus. ${ }^{12}$ Before the 1970s, Great Britain and Ireland (permanently since 1916) as well as Italy (since 1966) had been the only European countries using DST (Fig. 1). The United States had re-introduced DST on a national level in 1966 , but before that, it had only been applied on a regional or municipal scale. The breakthrough in the late 1970 s and early 1980 s coincides with the so called 'oil crisis' and, in retrospect, stresses the link between energy saving and DST. The perception of DST as an emergency measure was central

11 | Cf. "Stellungnahme der Bundesministerien zur Frage der Einführung der Sommerzeit”, February/March 1951; "ADAC Motorwelt to Bundesinnenministerium", Munich 28.02.1967, in: BArch, B 106, no. 104135.

12 | In 1919, for example, the National Coal Commissioner (Reichskohlekommissar) "after detailed investigation came to the conclusion that the savings in coal will carry no weight." "Reichsminister des Innern to Preußischer Ministerpräsident", Berlin 29.03.1924, in: BArch, R 3101, no. 10361. 
to public expectations, and renewed attempts of other nations amplified historic experiences.

In October 1973, the Arab Petroleum Exporting Countries (OPEC) proclaimed an oil embargo in response to the Israeli Yom Kippur War. This led to an unprecedented rise in oil prices and caused Western countries to rethink their dependence on fossil fuels. In the United States, shifting clocks was an immediate reaction to these events. President Nixon asked Congress to pass emergency legislation to authorize DST on a year-round basis. Only six weeks after the oil embargo was launched, House and Senate passed the 'Emergency Daylight Saving Time Energy Conservation Act.' It provided for a two-year trial period starting January 6,1974 . But the public opposed year-round DST because of the dark winter mornings. Energy savings of 0.7 to 1.0 percent of the monthly demand failed to convince as an argument. The scheme was suspended from November 1974 to February 1975 and the United States returned to the old system. ${ }^{13}$ Then, in spring 1975, President Giscard d'Estaing announced that he planned to introduce DST in France the following year. In public as well as in consultations with its partners in the European Economic Community (ECC), France's main argument was energy saving. Le Monde explained to its readers: "c'est l'objectif de l'operation." ${ }^{4}$ The government expected savings of 300,000 tons of oil.

The German parliament likewise discussed DST in the context of the 'oil crisis'. In December 1973, Kurt Spitzmüller, a liberal member of parliament, started an inquiry into this question. The Federal Ministry of Economics agreed to examine the effects of DST, but the administration pre-estimated savings of only 0.1 to 0.2 percent of annual energy consumption. ${ }^{15}$ In the following months, further enquiries and government statements showed

13 | Cf. Prerau: Seize the Daylight, 190-192.

14 | "La nouvelle heure d'été", in: Le Monde, 09.03.1976, 42. Cf. "Memorandum über die Zweckmäßigkeit einer Koordinierung auf Europäischer Ebene zur Einführung eines Sommerzeitsystems", Bruxelles 21.04.1975, in: BArch, B 106, no. 104136.

15 | Deutscher Bundestag: Stenographische Berichte der Verhandlungen des Deutschen Bundestages, 13.12.1973, 4415. Cf. "Sparen mit der Sommerzeit", in: Die Zeit, 14.12.1973. For earlier statements cf. Bundesministerium des Innern to Petitionsaussschuß des Bundestags, Bonn 16.09.1966, in: BArch, B 106, no. 104135. 
that politicians did not see a compelling connection between DST and energy saving. The administration in Bonn had developed a doubtful rating of DST's energy effects in the previous decades that persisted throughout the 1970s. The East German leadership did not take up the initiative at all, even though the People's Republic of Poland followed the French example in $1977 .^{16}$ So, if the Western and Eastern neighbors introduced DST out of energy considerations, why didn't East and West Germany do the same? Did energy policy not matter to them?

\section{Daylight Saving and Energy Policy}

The oil price shock of 1973 was not the direct stimulus for implementing DST in either West or in East Germany. In the case of the GDR (German Democratic Republic), this attitude is not surprising, as the crisis did not affect the country at all. At the beginning of the 1970s, East Germany did not depend on oil the way West Germany did - oil covered 13 percent of primary energy demand in the East compared to 53.1 percent in the West. Instead, lignite accounted for 78.4 percent of East Germany's supply. Furthermore, the 'oil crisis' was not a price shock, as payments within the Comecon (Council for Mutual Economic Assistance) did not reflect the prices on the world market. The crude oil price for deliveries from the Soviet Union was agreed upon by contract for five-year periods. Starting in 1975, prices were based on the average world market price of the previous five years. As a result, rising prices reached the East German economy with a time lag. By the end of the 1970s, however, the relevance of oil imports had grown significantly. Hence, the Politbureau initiated a reorientation of energy policy in 1979, and the shift away from oil was accelerated after 1981. This led to a rise in the use of lignite from 63.4 percent in 1979 to over 70 percent throughout the 1980 s. $^{17}$

16 | The country had earlier experiences with DST in the years 1957 to 1964 (and as an occupied country in World War II). Cf. "Deutsche Botschaft to Auswärtiges Amt”, Warsaw 06.12.1976, in: Politisches Archiv Auswärtiges Amt (PA AA), Zwischenarchiv, no. 109.340.

17 | Cf. Barbara Breuer: Die Energiewirtschaft der Bundesrepublik Deutschland und der DDR im Vergleich. München: Oldenbourg, 1987, 78; Harm G. Schröter, “Ölkrisen und Reaktionen in der chemischen Industrie beider deutscher Staaten. 
West Germany had conducted a comparable re-orientation of energy policy subsequent to the developments of 1973 . The share of oil was reduced to 43.5 percent within ten years. ${ }^{18}$ At the same time, the Energy Security Act (Energiesicherungsgesetz) of November 1973 took immediate measures to reduce oil consumption. Even today the so called 'car-free Sundays' have a place in German collective memory, although their symbolic power vastly exceeded their actual energy effect. ${ }^{19}$ In the context of this policy, it is surprising that the idea of daylight saving did not persuade government officials. One compelling argument against 'ad hoc action' were trafficrelated problems. Here, some attention had to be given to the coordination of European timetables, and according to experts this required a preparation period of at least twelve months. ${ }^{20}$ However, the Ministry of Economics remained interested and, for further inquiry, obtained expert advice from Professor Helmut Schaefer of the 'Research Center in Energy Economics' (Forschungsstelle für Energiewirtschaft) in Munich. Schaefer submitted a first report in September 1974, before then publishing his results at various times with several revisions. According to his calculations, introducing DST from April to September could save about 5 percent of the annual demand for lighting electricity (1.7 terawatt hours). This was equivalent to 0.6 percent

Ein Beitrag zur Erklärung wirtschaftlicher Leistungsdifferenzen", in: Johannes Bähr/Dietmar Petzina, eds. Innovationsverhalten und Entscheidungsstrukturen. Vergleichende Studien zur wirtschaftlichen Entwicklung im geteilten Deutschland 1945-1990. Berlin: Duncker \& Humblot, 1996, 114; Friedrich-Ebert-Stiftung, ed.: Die Energiepolitik der DDR. Mängelverwaltung zwischen Kernkraft und Braunkohle, Bonn: Verlag Neue Gesellschaft, 1988, 26-27. It must be considered that payments were processed in so called transfer roubles.

18 | Cf. Breuer: Energiewirtschaft, 78. For the wider historical context, cf. Rainer Karlsch/Raymond G. Stokes: 'Faktor Öl'. Die Mineralölwirtschaft in Deutschland 1859-1974. München: Beck, 2003, 325-278; Rüdiger Graf, “Between National and Human Security: Energy Security in the United States and Western Europe in the 1970s", in: Historical Social Research 35:4 (2010), 329-348.

19 | Cf. Jens Hohensee: “Und sonntags wieder laufen... Die erste ,Ölkrise“ 1973/74 und ihre Perzeption in der Bundesrepublik Deutschland", in: Michael Salewski/Ilona Stölken-Fitschen, eds. Moderne Zeiten. Technik und Zeitgeist im 19. und 20. Jahrhundert. Stuttgart: Franz Steiner, 1994, 175-196.

20 | "Bundesverkehrsministerium to Bundesministerium des Innern", Bonn 21.12.1973, in: BArch, B 106, BMI, no. 104135. 
of total electricity demand and 0.08 percent of total energy demand. Schaefer described this as impossible to measure, however, as the effects of business fluctuations or annually changing weather conditions exceeded these projected savings. Additionally, Schaefer assumed increasing energy consumption in other sectors. First, this was the case with automobile traffic which was stimulated by daylight in the evening. Furthermore, DST increased the demand for heating: "The 'low temperature point' of the day is now part of the main heating time." ${ }^{21}$ Hence, it was pointed out that DST had a reverse effect on oil consumption: "The savings of coal, water and nuclear energy are replaced by an increased consumption of oil products for road traffic and heating." 22

The rapid downturn of political debates on DST in Germany indicates that Schaefer's point of view was widely accepted. However, although the energy topic disappeared from ministerial papers, newspapers still presented this perspective in looking at the debates on a new Time Act. "DST should allow for a better use of daylight - thus making energy savings possible," the Süddeutsche Zeitung simplified in 1978..$^{23}$ West German politicians now discussed a symbolic value of daylight saving. Parliamentarian Torsten Wolfgramm (FDP) argued in 1977 that "the psychological effect of time change will clearly be a notable momentum in regard to energy saving." ${ }^{24}$ Here, the collective practice of changing clocks was interpreted as a stimulus for public awareness. But experts like Schaefer opposed this strategy sharply: "This approach does a disservice to true efforts to use energy economically, which can only be achieved through appropriate information of each individual." 25

$21 \mid$ K. F. Ebersbach/H. Schaefer: "Sommerzeit und Energieeinsparung. Überraschendes Ergebnis einer detaillierteren Untersuchung: Es wird mehr Öl verbraucht", in: Energiewirtschaftliche Tagesfragen 30 (1980), 497. As a summary “Note: Einführung der Sommerzeit”, Bonn 10.09.1975, in: BArch, B 106, BMI, no. 104136.

22 | Ebersbach: “Sommerzeit”, 498. Cf. Gerhard Bischoff/Werner Gocht: Das Energiehandbuch. $4^{\text {th }}$ ed. Braunschweig: Vieweg, 1981, 350.

23 | Diethart Goos: “Bonn kann jetzt die Uhren vorstellen - tut es aber nicht”, in: Die Welt, 23.06.1978.

24 | Deutscher Bundestag: Stenographische Berichte der Verhandlungen des Deutschen Bundestages, Bonn 05.05.1977, 1750.

25 | Ebersbach: "Sommerzeit”, 498. 
In East Berlin, the DST debate started with a considerable time lag. The presidency of the Council of Ministers established a working group in March 1977, but in the end, GDR experts came to results that were surprisingly similar to those of their West German counterparts. The Ministry for Coal and Energy calculated that annual savings would amount to 60 gigawatt hours - equivalent to 0.06 percent of the total energy demand of 1976 . In 1980 , energy savings were officially estimated at 100 gigawatt hours (the demand of 80,000 households) or 200,000 tons of lignite. ${ }^{26}$ Additionally, energy experts saw positive effects of not introducing DST. International time differences were seen as advantageous, as this reduced the peak load of the East European electricity network system. ${ }^{27}$ In conclusion, officials in East and West Germany shared a reserved or even negative judgment of DST's energy saving possibilities.

This is an obvious contradiction to the interpretation of DST as an energy saving measure; or at least it indicates that we must interpret decisionmaking processes in a wider context. Energy policy is not determined by simple, hard facts. Additional factors that frame the perception of energy saving must be taken into account. The obvious differences in political and social evaluation of DST mainly reflect the complexity of energy regimes and their cultural settings. Material differences as well as cultural (mis)interpretations of energy flows have to be reconsidered. In regard to the German debates of the 1970s, this leads to two specific questions: First, why did the German judgment differ from neighboring countries? Second, why didn't the experts' opinion determine the public perception of DST?

Here, the statements of the German experts involved can give important evidence. Their discussions often focused on differences in lifestyle. The Council of Ministers of the GDR explained the different approach of France and Poland with differences in everyday rhythms of life:

"The advantages in countries that advance standard time by an hour are a question of energy management. This is mainly connected with the fact that

26 | Cf. “Neumann to Stoph”, Berlin 09.03.1977, in: BArch, DC 20, no. 9438; “Draft: Ab 6. April: Sommerzeit in der DDR”, in: BArch, DC 9, no. 104; “17. Sitzung des Präsidiums des Ministerrates”, 10.03.1977, in: BArch, DC 20, no. I/4/3743.

27 | Kulturbund der DDR, ed.: Energiepolitik und Kulturfortschritt. Berlin: Kulturbund der DDR, 1981, 21. 
their lifestyles are different than in East Germany (starting work later, breaks from work at lunchtime and thus working later into the night, also an extensive entertainment industry that runs far beyond midnight). ${ }^{28}$

The West German government similarly advanced the argument of differences in evening energy consumption in the case of Italy, stating that "the problem seems to be different because of the long midday rest." ${ }^{29}$ This figure of thought became commonly used. The Spiegel magazine highlighted differences in consumption patterns in relation to the United States arguing that "even more than in glittering America [...] the hopes of a crisis time-setting in the comparatively light-poor Federal Republic is illusory." ${ }^{30}$ In regard to intra-German differences, West German officials pointed to "East German citizens, whose everyday life, in general, starts earlier and ends earlier." ${ }^{11}$ Along the same lines, West German specialists expected, "that more daylight in the evening will lead to an extension of 'activity time' and, therefore, a considerable reduction of sleep." 32 Experts did not come to a conclusion whether this led to an increase in energy consumption or not. But their considerations clearly emphasize that the implementation of DST was related to complex social and cultural processes that go far beyond energy saving. 33

28 | "Neumann to Stoph”, Berlin 09.03.1977, in: BArch, DC 20, no. 9438. In the case of Poland, it was said that this was visible in different daily load curves of electricity as "we [the GDR] deliver electricity to Poland in the evening and derive electricity from them for our peak demand in the morning.", "Niederschrift über die am 21. März 1977 stattgefundene 2. Beratung über die Zweckmäßigkeit der Einführung der Sommerzeit in der DDR entsprechend dem Beschluß des PMR vom 10. März 1977", in: BArch, B 106, no. 104136.

29 | "Kurzprotokoll über die Ressortbesprechung am 28. Mai 1975 im BMI", Bonn 30.05.1975, in: BArch, B 106, no. 104136.

30 | “Leuchtet schön”, in: Der Spiegel, 04.02.1974, 53.

31 | "Aktennotiz des Arbeitsstab Deutschlandpolitik: Zeitgesetz", Bonn 08.06.1978, in: BArch, B 136, no. 18391.

32 | Ebersbach: "Sommerzeit", 497.

33 | For the cultural dimension of time, cf. Robert Levine: A Geography of Time. The Temporal Misadventures of a Social Psychologist, or How Every Culture Keeps Time Just a Little Bit Differently. New York: Basic Books, 1997; Hartmut 
A second set of arguments evolved around the role of geographic preconditions. It is important to realize that the global system of standardized time zones established in the late $19^{\text {th }}$ century has its counterpart in diverging times of sunrise and sunset from place to place. As the length of day in summer decreases on your way south, the positive effect of DST in France exceed the results in Germany where sunset (on average) is already later on standard time. ${ }^{34}$ Additionally, not only latitude, but also longitude influences the results of DST. For instance, Poland is east, while Germany is west of the relevant time meridian $15^{\circ}$ East (the meridian of Görlitz). As a result, the sun rises and sets earlier in Poland, thus increasing the daylight saving effect of changing clocks. Even without a detailed discussion or empirical data it is plausible that geographic factors as well as cultural differences had at least some effect on the outcome of DST. But most of the discussants did not acknowledge the different framework conditions. Many newspaper articles indicate that the perception of DST in other countries influenced debates in Germany. This is one reason why - as Schaefer pointed out - "every time [DST] was discussed, the main argument was energy saving for artificial lighting." ${ }^{35}$ The traditional public perception of DST as an emergency measure (as described earlier) probably served as a basis for this development.

Additionally, disputes over DST highlight both the technical importance and the social unawareness of energy's multiple materialities. The widespread notion of 'energy' as a uniform entity - regardless of where it comes from and where it is going - often blurred the differences between energy resources and their transformation. On the side of energy input, the question of which energy source satisfied which kind of demand is crucial to understand diverging national priorities. In Germany, saving electricity for lighting could not significantly help to reduce oil consumption in the 1970s, but a higher oil input for electricity generation did substantiate the

Rosa: Alienation and Acceleration. Towards a Critical Theory of Late-Modern Temporality. Malmö: NSU Press, 2010.

34 | Cf. “Note: Sommerzeit”, Bonn 22.07.1975, in: BArch, B 106, no. 104136. The effect is observable in Germany as well. On August 1, for example, Hamburg has 43 minutes more daylight than Munich.

35 | Ebersbach: "Sommerzeit”, 496. 
energy effect in France. ${ }^{6}$ On the side of energy use, high expectations can be attributed to common misperceptions of energy demand for specific applications. In 1980, a newly added chapter on DST in the fourth edition of Gerhard Bischoff and Werner Gocht's Handbook of Energy pointed out that one kilowatt hour can either be used for illuminating a 60 watt light bulb for 17 hours or for showering with warm water for two minutes. ${ }^{37}$ The example illustrated the fact that lighting has a comparably low energy consumption while DST could only save energy used for light, but not energy used for heat or power. Historically, this constraint led to a decrease in energy saving potential. In proportion to other uses, the expenditure for lighting diminished: In 1960, West German households used one quarter of their total electricity demand for lighting. In 1980, this share had decreased to 10 percent - even though absolute lighting energy use had doubled. ${ }^{8}$ Additionally, increasing leisure time and leisure time facilities led to a situation where the social effects of DST overcompensated for its energy effects. Increased consumption of energy due to a higher standard of living, in general, reduces the (relative) potential of DST to save energy.

While the pitfalls of a highly aggregated concept of energy help to explain differences in the perception of saving potentials, the effects of cultural, social, and technical settings described before illuminate some national varieties. However, differences in numbers alone were not decisive for political decision-making. In the end, energy saving effects elsewhere neither substantially outranked Germany, nor were they extremely overrated or misjudged. Even French officials did not consider the calculated savings as outstanding. It is illuminating that they did not speak of (less impressive) percentages that could be saved, but of millions of tons of coal or oil (as did advocates of DST in Germany). Here, more general ideas about energy policy and government strategies come into play. A decisive difference between supporters and critics of DST was the appreciation of smaller achievements in energy saving - either in a material or a symbolic sense. In this spirit, the Bavarian Minister of Economy and

36 | In 1972, oil covered $67.3 \%$ of French, but only 55.2\% of German energy demand. Cf. Hans R. Krämer: Die Europäische Gemeinschaft und die Ölkrise. Baden-Baden: Nomos, 1974, 56.

37 | Bischoff: Energiehandbuch, 350.

38 | Cf. Reinhard Schüssler: Der Energieverbrauch der privaten Haushalte, Frankfurt/Main: Lang, 1987. 
Transport advocated DST in 1974, stating that "only the full exploitation of all possibilities in total" can lead to success. ${ }^{39}$

Most West and East German officials, however, did not follow this kind of step-by-step rationality. In their minds a rather complex image of advantages and disadvantages of the new time scheme emerged. When clocks were advanced by one hour on April 6, 1980, the energy argument was part of the official statements, but by no means their core message. A West German government spokesman proclaimed: “DST permits a better use of daylight in the evening hours, so that even more outdoor activities are possible. It can also entail a certain degree of energy saving." ${ }^{\circ}$ In the newspaper Neues Deutschland, the East German leadership argued quite similarly:

"Citizens have better opportunities for recreation, sports, and other spare time activities in the summer evenings. To a certain degree, economic reserves can be mobilized. The longer use of daylight improves working conditions for the second shift, especially for outdoor work like construction and transportation. Also, savings of electricity, especially for lighting, are expected.." ${ }^{41}$

According to political players, this wide variety of motives led to the implementation of DST. Various aspects highlight the social embeddedness of energy rationality: the role of different geographical, technical and socioeconomic ideas and settings both within Germany and in regard of its neighbors. But the German example also illustrates the dependence of energy policy on wider political configurations and developments. Here, daylight saving became an arena for intra-German negotiations.

39 | "Jaumann to Friderichs", München 25.06.1974, in: BArch, B 106, no. 104135.

40 | “Note: Einführung der Sommerzeit”, Bonn 04.02.1977, in: BArch, B 136, no. 18391.

41 | “Was bezweckt Sommerzeit?”, in: Neues Deutschland, 21/22.10.1979, 2. 


\section{The Shared Political History of DST in Divided Germany}

On April 28, 1978, the West German Chancellor, Helmut Schmidt, wrote a letter to Erich Honecker, General Secretary of the Central Committee of the Socialist Unity Party of Germany (SED) and Chairman of the Council of State of the GDR. Schmidt explained:

"It is of great importance for the Federal Government to learn the position of the German Democratic Republic regarding the question of introducing daylight saving time. [...] It is in the interest of good-neighborly cooperation within Europe to avoid time differences between the different states as far as possible." ${ }^{42}$

In a rather direct way, the West German government tried to persuade its counterpart in the East to introduce DST. But the answer from East Berlin, coordinated by Günter Mittag, Secretary of Economy at the Central Committee of the SED, was negative. It stated that the implementation was not planned as there were "no advantages, but instead disadvantages for various aspects of people's work and lives." 43 Party officials had reevaluated the results of the working group of 1977, and they had come to the conclusion that there were no noteworthy economic advantages and that "the decision to implement DST can only be made from a political point of view." 44 First of all, this meant that it was a matter of international coordination and not of energy policy. At the same time, this interpretation gave room for political maneuver and demarcation from West Germany.

This was especially the case since Schmidt and his social-liberal government were under severe political pressure. DST had become a matter of European integration, after France had opted for DST "in a then surprising decision" 45 and formally asked its EEC-partners to join the new

42 | "Helmut Schmidt to Erich Honecker", Bonn 28.04.1978, in: BArch, DY 30, no. 3020 .

43 | Cf. "Protokoll Nr. 20/78 zur Sitzung des Politbüros", 23.05.1978, in: BArch, DY 30, no. J IV 2/2/ 1727.

44 | "Abteilung Grundstoffindustrie des ZK der SED to Günter Mittag”, Berlin (East) 12.05.1978, in: BArch, DY 30, no. 3020.

45 | "Sprechzettel für den Regierungssprecher”, Bonn 18.10.1979, in: BArch, B 106, no. 104138. 
time regime. In 1977, seven of the nine members of the EEC used DST (with different start and end dates), with only Germany and neighboring Denmark opting out. In summer, West Germany had a new time border in the west, causing considerable difficulties, especially in transport. There was growing European pressure to introduce daylight saving, which led to the idea of writing directly to Honecker, even though the approach was controversial within the chancellery. The other cabinet members were only informed after the event. Only one of them, the Minister for Intra-German Relations, Egon Franke, learned of the wording of the correspondence. ${ }^{46}$ Throughout the discussions within the administration his ministry had emerged as one of the most important opponents of DST and had emphatically stressed the intra-German implications of unilaterally introducing DST. In retrospect, Franke pointed out:

"For years, people have called for the introduction of DST. So far, however, we have no reason to believe that East Germany will do the same, meaning that the introduction of DST would bring an additional time border to Germany and Berlin. It would create many difficulties for intra-German traffic and - still more - for listening to and viewing West German radio and television programs. [...] Every decision on this question should be made in a way that does not diminish the commonalities within Germany, but - wherever possible - extends them." ${ }^{47}$

In June 1978, a coalition discussion arrived at the conclusion that DST should not be introduced for the time being as, "compared to the importance of the inner German aspects, economic and technical advantages are not that essential." ${ }^{8}$ Nevertheless, in the same month parliament approved a new Time Act, which included an authorization to implement DST by ordinance. But government officials had to announce that they would not use this authorization unless they achieved an agreement with East

46 | “Note: Sommerzeit”, Bonn 05.05.1978, in: BArch, B 106, no. 18391.

47 | Egon Franke: "Speech given at Kuratorium Unteilbares Deutschland", 18.06.1979, in: Bundesministerium für Innerdeutsche Beziehungen, ed. Texte zur Deutschland-Politik, series II, vol. 7, Bonn: Deutscher Bundesverlag, 1981, 438439. Cf. “Note: Probleme einer Zeitgrenze in Deutschland”, Bonn 22.02.1977, in: BArch, B 136, no. 18391.

48 | "Chef des Bundeskanzleramts to Arbeitsstab Deutschlandpolitik", Bonn, 12.06.1978, in: BArch, B 136, no. 18391. 
Berlin. The emotional appeal of the debate is exemplified by the fact that Herbert Wehner, then chairman of the SPD parliamentary group, had his disagreement with the Time Act officially recorded because of his fear of a potential time border. ${ }^{49}$ This was the climax of a lengthy controversy. For a long time the Foreign Office had warned to not "inflate the affair as a false alternative - 'European Integration vs. Intra-German Policy' - but instead to address it as a practical task." 50 Now it looked as if DST had reached a dead end. The 'German Question' clearly superseded all other related issues.

In order to correctly assess the impact of the 'German Question' it is important to follow up the course of negotiations chronologically. A mutual decision of Bonn and East Berlin to introduce DST had several times seemed a possibility. In 1976 and 1977, there was evidence that East Germany would also shift to DST after Poland had decided to do so..$^{11}$ The Foreign Office - strongly supporting DST because of its possible "political psychological pro-Europe effect" 52 - scrupulously recorded every relevant statement from representatives of the GDR. In May 1977, for example, Dr. Meißner, counselor of the East German Permanent Representation, said that - if all neighboring states introduced DST - "the GDR in [his] opinion will possibly decide similarly." 53 By that time, the consultations of the East German working group had reached a positive outcome, despite its energy evaluations. It concluded that a "certain expediency of implementing DST"

49 | Cf. Deutscher Bundestag: Stenographische Berichte der Verhandlungen des Deutschen Bundestages, Bonn 22.06.1978, 8019.

50 | "Note from the Foreign Office: Zeitgesetz (Sommerzeit)", Bonn 17.05.1977, in: BArch, B 136, no. 18391.

51 | Cf. "Draft: Beschluss der Bundesregierung zur Frage der Sommerzeit in der Bundesrepublik Deutschland", Bonn 02.03.1976, in: BArch, B 106, no. 104137.

52 | "Bundesministerium für Jugend, Familie und Gesundheit to BMI", Bonn 16.07.1975, in: BArch, B 106, no. 104136. Cf. "Kurzprotokoll über die Besprechung am 12. Februar 1976 im BMI”, Bonn 19.02.1976, in: BArch, B 106, no. 104137.

53 | “Note: Gespräch zwischen Zilch und Dr. Meißner”, Bonn 03.05.1977, in: PA AA, Zwischenarchiv, no. 122.339. Cf. "Note: Äußerungen der DDR zur Sommerzeit", Bonn 16.06.1977, in: BArch, B 136, no. 18391. 
resulted from the "requirement of warranting undisturbed cross-border traffic of passengers and goods." 54

Of course, West German officials did not know this. Instead, there were controversial political debates. In June 1977, Herbert Wehner personally made sure that the Time Act was removed from the parliamentary agenda at short notice. Two days before the scheduled vote, he had received a cable from the Confederation of German Trade Unions (DGB). It gave a warning "in the interest of health protection of a great part of the workforce not to introduce DST, especially because of the additional health risks for shift and night-shift workers." 55 Although the unions redrew their protest soon afterwards, the delay of decision altered the course of action. In September, Meißner was more restrained: "For them [i.e. the GDR leadership] there are certain sociological and medical concerns. There is no economic benefit. But our [i.e. the West German] decision is important for the GDR." ${ }^{6} 6$ Finally, an 'Ordinance on the determination of standard time in the GDR' (Verordnung über die Festlegung der Normalzeit in der DDR) was released that did not mention DST.

One has to conclude that chances were good for a shared introduction of DST in the summer of 1977 - due to international interdependencies, not energy saving. Expert groups from both countries perceived the problem as multidimensional. As early as 1975, the West German Home Office observed: "Every decision pro and contra can be supported by good arguments. We should thus avoid an all too hasty decision."57 The East German Council of Ministers followed a similar, two-pronged strategy in $1977 . .^{8}$ The delayed decision in West Germany, however, diminished the

54 | "Niederschrift über die 2. Beratung über die Zweckmäßigkeit der Einführung der Sommerzeit in der DDR entsprechend dem Beschluß des PMR vom 10. März 1977", Berlin 21.03.1977, in: BArch, DC 20, no. 9438.

55 | "DGB to Herbert Wehner", Düsseldorf 14.06.1977, in: BArch, B 136, no. 18391.

56 | “Note: Gespräch zwischen Zilch und Dr. Meißner”, Bonn 26.09.1977, in: BArch, B 136, no. 18391.

57 | “Note: Sommerzeit”, Bonn 06.05.1975, in: BArch, B 106, no. 104136.

$\mathbf{5 8}$ | As a matter of fact, the working group elaborated lines of argument for both outcomes. "Niederschrift über die 3. Beratung über die Zweckmäßigkeit der Einführung der Sommerzeit in der DDR entsprechend dem Beschluß des PMR vom 10. März 1977", 28.03.1977, in: BArch, DC 20, no. 9579. 
arguments of international coordination and let to a repositioning of the GDR leadership. For two years there was no significant progress on the intra-German agenda. But on October 11, 1979, the Council of Ministers of the GDR decided to implement DST in the following year. East Berlin informed the Federal Chancellery by phone on October 15. The West German cabinet debated the question two days later and finally, on October 24, decided for DST.

Because of the limited sources it is difficult to judge the decisionmaking process in the Politbureau. The move was interpreted as a sign of détente in the West German press. The official records do not reflect the notion that DST was exploited for political reasons of demarcation or appeasement.59 If we want to understand energy policy, however, it is not necessarily crucial to define beyond doubt the role of hard politics. Instead it is more illuminating to see how fears and pure assumptions interfered with decision-making. From today's perspective, it seems convincing to explain the East German changes in attitude both in 1977 and 1979 in regard to energy policy. In the fall of 1979, East Germany made a decisive turn in energy policy in order to "enforce a deliberate, high discipline in the use of energy everywhere and stop any waste of energy in the interest of society in general."60 Additionally, the international constellation had changed once more after Czechoslovakia had introduced DST in 1979. Thus, actual advantages and disadvantages of DST determined the position of the GDR. One case in point is the fact that - unlike in West Germany - the topic was clearly discussed from an energy perspective in the administration and party apparatus: Lead-agencies were the Ministry for Coal and Energy and the Division for Primary Industry of the Central Committee of the SED. In West Germany, the Home Office was the lead-agency. The different

59 | The point can only be found in the mirror-inverted argument that the decision-making of the EEC was "like extortion". "Niederschrift über die am 21. März 1977 stattgefundene 2. Beratung über die Zweckmäßigkeit der Einführung der Sommerzeit in der DDR entsprechend dem Beschluß des PMR vom 10. März 1977", in: BArch, B 106, 104136.

60 | Cf. "Beschluß des Ministerrates der DDR über rationellen und sparsamen Einsatz von Elektroenergie, Wärme sowie Brenn- und Treibstoffen”, in: Neues Deutschland, 21.09.1979. 
perspective is apparent in the title of the files from the chancellery, which was 'Summertime in Europe in relation to the Berlin traffic.' ${ }^{\prime} 1$

There is another 'surprise twist' in the intra-German story. On October 8, 1980, the East German leadership declared that it did not plan to use DST in 1981, "because the experiences of this year show that there are no advantages connected with it." ${ }^{62}$ West German newspapers spoke of an "intra-German ice age." ${ }_{3}$ Only two months later, the GDR revoked its decision. The Soviet Union had decided to implement DST, and changing clocks became a question of "coordination with the socialist countries." 64 Again, it is too easy to label East German politics as a power game. From an energy perspective abolishing DST was a rational decision; or as the newspaper Neues Deutschland put it: "Based on scientific expertise, that is available to the government of the GDR, and the experiences of the year 1980 [...] it is not advisable to repeat the experiment with DST next year."65

It is not a coincidence that international dependencies were decisive in keeping DST in East Germany, as they were for its introduction in West Germany. In both countries the decision-making process was superseded by political interests of international integration. In the long run, not energy politics, but power politics or, to be more precise, the anticipation of power politics determined the outcome of the debates. Of course, divided Germany during the Cold War era is a rather special case, but this is not an argument for ignoring the historical interweaving of energy issues and politics. Even more telling, interdependencies between the transnational political setting and economic and technical considerations worked out

61 "Sommerzeit in Europa im Zusammenhang mit dem Berlinverkehr", 197578, in: BArch, B 136, no. 18391.

62 | "Protokoll Nr. 40/80 zur Sitzung des Politbüros", 08.10.1980, in: BArch, DY 30 , no. J IV 2/2/1860.

63 Joachim Nawroth: "Rückgriff auf Ulbrichts Rezepte", in: Die Zeit, 11.11.1980.

64 | "Protokoll Nr. 49/80 der Sitzung des Politbüros", 02.12.1980, in: BArch, DY 30 , no. J IV 2/2/1869.

65 | "Keine Sommerzeit für 1981", in: Neues Deutschland, 28.10.1980. A similar interpretation is given by the Spiegel magazine: "The decision of the GDR against DST, viewed as a new act of demarcation in the West, mainly has economic reasons.", “Verlorene Zeit”, in: Der Spiegel, 03.11.1980, 40. 
differently in East and West in regard to energy saving. In a large part this can be attributed to different societal debates on energy policy.

\section{The Social Role of Energy Conservation}

Questioning a well-established time regime must be interpreted as a sign of deep-rooted uncertainty in a society. Throughout the German debates one point seems certain: If the energy effect had been larger, this would have decided it for DST. In 1974, the West German Home Office made clear: "In answering this core question it will be possible to draw the necessary conclusions for the introduction of DST. Other aspects cannot be [...] of any relevance for the decision, if the question of energy is answered in a way that makes the introduction of DST compelling." 66 This readiness to change clocks for energy considerations, therefore, indicates the immense importance that was given to energy supply.

In West Germany the social importance of energy saving is central to explaining why the implementation of DST did not encounter more serious resistance: Perceived as an energy saving measure, DST fits perfectly within the guiding political principles of the 1970 s as a decade of crisis. Additionally, it corresponded to the mixture of insecurity and search for alternative orientation in society. The oil price shock of 1973 - revitalized in the rising oil prices of the late 1970 - led to a new energy policy. The economy of the early Federal Republic had been subject to a "primacy of the cheapest energy supply possible." ${ }^{67}$ Now, more weight was given to energy security and a diversification of supply. Before, cheap energy not only contributed considerably to an impressive economic growth and a rising living standard; it also symbolized this development. In his book on the 'oil price shock',

66 | "Haushaltsreferat to Referat VI6", Bonn, 26.07.1974, in: BArch, B 106, no. 104135.

67 | Martin Czakainski: "Energiepolitik in der Bundesrepublik 1960 bis 1980 im Kontext der außenwirtschaftlichen und außenpolitischen Verflechtungen", in: Jens Hohensee/Michael Salewski, eds. Energie - Politik - Geschichte. Nationale und internationale Energiepolitik seit 1945. Stuttgart: Franz Steiner, 1993, 17. Cf. Hans Michaelis: "Die Energiewirtschaft der Bundesrepublik Deutschland von 1970 bis 1990", in: Hohensee/Salewski, eds. Energie - Politik - Geschichte, 51-74. 
Jens Hohensee speaks of a "change in attitude in society." 68 In general, the crisis is seen as the starting point for debates on energy saving in West German society. The practical results were considerable. Due to government provisions specific industrial energy consumption was reduced by almost 25 percent between 1973 and 1986, when heating one square meter of housing space required 20 liters of fuel oil instead of 29 liters. ${ }^{69}$

Judging the scope of these savings must remain controversial. Hohensee states that "this process of reflection and the change in attitude was not persistent." $7 \circ$ It might at least be said that the focus shifted from 'energy saving' to 'energy efficiency'. The reinterpretation of energy consumption was difficult because, in essence, it questioned the idea of progress. In the 1970 s, the political discussions on energy still advanced the assumption of a tight connection of economic growth and increases in demand for primary energy. Although the idea of 'decoupling' was discussed - with some controversy - the political focus was on new energy options, mainly nuclear fission. ${ }^{71}$ The Energy Security Act (1973), the Energy Saving Act (1975), and the regularly updated Energy Program of the Federal Government gave political stimulus for raising energy efficiency. But at the same time even proponents of energy saving avoided an equation between energy saving and austerity: "This perception does more harm than good; [...] the aim to use energy efficiently and therefore economically is much more comprehensive and does not focus on a sacrifice of comfort." ${ }^{2}$ Under these circumstances

68 | Jens Hohensee: Der erste Ölpreisschock 1973/74. Die politischen und gesellschaftlichen Auswirkungen der arabischen Erdölpolitik auf die Bundesrepublik Deutschland und Westeuropa. Stuttgart: Franz Steiner, 1996, 236-238.

69 | Cf. Bundesminister für Wirtschaft, ed. Energiebericht der Bundesregierung vom 24.09.1986, Bonn: Bundesregierung, 1986, 31.

70 | Hohensee: “Und sonntags wieder laufen...”, 193.

71 | Cf. Werner Müller/Bernd Stoy: Entkopplung. Wirtschaftswachstum ohne mehr Energie? Stuttgart: Deutsche Verlags-Anstalt, 1978; Klaus Traube/Otto UIIrich: Billiger Atomstrom? Wie die Interessen der Elektrizitätswirtschaft die Energiepolitik bestimmen. Reinbek: Rowohlt, 1982; Alfred Geißler/Botho Riegert: Energiepolitik für eine lebenswerte Zukunft. Kohle contra Super-GAU. Bonn: Verlag Neue Gesellschaft, 1988.

72 | Geißler: Energiepolitik, 63. Cf. Deutscher Bundestag, ed. Energiepolitik im Deutschen Bundestag (7. und 8. Wahlperiode). Bonn: Deutscher Bundestag, 1980. 
it seems obvious that saving without sacrifice would have been the charm of DST from an energy perspective. The linkage between energy saving and DST, therefore, is not only evidence of the deep roots of energy saving in society, but also of its limits. Or, as Klaus Meyer-Abich wrote:

"The broad consensus that energy saving is a good thing is problematic in the sense that it partially involves an interest in setting the principle so high that everybody involved is allowed to easily slip through. The truly interesting question is not whether we are in favor of saving energy, like we are in favor of family and against war, but instead where, when, how, how much energy can be saved, and by whom?"73

Saving energy legitimized DST. At the same time, DST created acceptance for energy saving as it allowed everybody to contribute without changing individual consumption patterns.

In East Germany, DST was part of a technocratic approach to the problem. A similar change in attitudes like the one in West Germany could only have occurred with delay and only gradually. The 'oil crisis' was interpreted as a crisis of the capitalistic system. Until the mid-1970s high energy input was viewed as "proof of the economic power of true socialism."74 East Germany long took pride in numbers showing that total electricity production exceeded that of France or West Germany. In retrospect, Otto Reinhold, president of the Academy of Social Sciences of the Central Council of the SED, pointed out:

"In the past, the prevailing opinion was that more production, more national income could only be achieved through more material, more energy, and more investment. By now, we have realized that economic growth is only possible if existing resources are used more efficiently."75

73 | Klaus M. Meyer-Abich, ed. Energieeinsparung als neue Energiequelle. Wirtschaftspolitische Möglichkeiten und alternative Technologien. München: Hanser, 1979, 27.

74 | Friedrich-Ebert-Stiftung, Energiepolitik, 7. Cf. Institut für Internationale Wirtschaft und Politik, ed. Energie- und Rohstoffprobleme im heutigen Kapitalismus, Berlin (East): Institut für Internationale Wirtschaft und Politik, 1978.

75 | Otto Reinhold: “Über die wachsende Dynamik unserer wirtschaftlichen und gesellschaftlichen Entwicklung”, in: Gesellschaftschaftswissenschaftliche Kon- 
The policy shift bears a resemblance to West German debates. Energy prices for industrial usage rose significantly after 1976. September 1979 became a turning point in energy policy, when state holding companies were subjected to strict maximum demands for energy. In 1981, after the Soviet Union reduced its export quantities, these measures were tightened; energy policy now resembled "pulling the emergency break." ${ }^{6}$ The officially mandated energy-saving measures were more comprehensive and somehow more fundamental compared to those in West Germany. In the following years, the East German economy was able to disconnect growth and energy demand. But in the long run, the efforts were of little effect. Per-capita consumption of primary energy exceeded West Germany by 25 percent in 1987 , which indicated a low degree of energy efficiency especially since the GNP per capita was approximately one quarter lower.77

The political system of the GDR cut off the emergence of an energy debate comparable to that in West Germany. Energy saving was ordered from above and governed by technocrats. To some extent, the limited results emerged from a lack of willingness to directly cut back private energy consumption. The government had kept the price for a kilowatt hour of electricity constant at 8 Pfennig since 1946. Energy experts were aware of the fact that "state-subsidized prices for energy [...] were no material stimulus for an economical use of energy in households." ${ }^{8}$ But they were kept as a matter of ideology and social policy. Attempts to mobilize citizens for energy saving remained limited despite of corresponding media campaigns. Emphasis was given to industrial productivity and official

ferenz des ZK der SED, ed. Gesetzmäßigkeiten unserer Epoche - Triebkräfte und Werte des Sozialismus. Berlin (East): Dietz, 1984, 158. Cf. Hans J. Hildebrand: Wirtschaftliche Energieversorgung. $3^{\text {rd }}$ ed. Leipzig: Deutscher Verlag für Grundstoffindustrie, 1975, 78-79.

76 | Schröter: “Ölkrisen”, 121. Cf. Willi Riesner: Rationelle Energieanwendung. $2^{\text {nd }}$ ed. Leipzig: Deutscher Verlag für Grundstoffindustrie, 1982, 3.

77 | According to the information available, between 1979 and 1983 GNP rose $4.1 \%$, while energy consumption decreased by $0.7 \%$. Cf. Wolfgang Stinglwagner: Die Energiewirtschaft der DDR unter Berücksichtigung internationaler Effizienzvergleiche. Bonn: Gesamtdeutsches Institut, 1985, 17; Breuer: Energiewirtschaft, 111.

78 | Kulturbund der DDR: Energiepolitik, 12-13. 
ordinances. As a consequence, although energy saving was a public issue, debates did not reflect the full complexity of energy demand. ${ }^{79}$

Under the given circumstances, a symbolic dimension of DST as energy saving time - complementing or substituting energy savings could hardly emerge. Debates on DST mainly mirrored prevailing ideas of social and economic management and its implementation. East and West Germans shared the idea of energy as basis for economic growth and symbol of living standard - until this image was shattered in the 1970 . On the one hand, different sources of energy and the resulting differences in the course of crisis help to explain the different approaches in divided Germany. On the other hand, political ideologies and strategies as well as basic societal mechanisms contributed to diverging dynamics and meanings of energy policy. Once more, this demonstrates that DST cannot be examined as an isolated phenomenon. Instead, the starting point of any historical analysis must include its social context.

\section{Conclusions}

Energy was the starting point of debates on DST in Germany in the 1970 . Shifting clocks emerged as a measure of 'social engineering' recalling experiences from two world wars. However, there is no distinct and onedimensional connection between energy saving and daylight saving. First of all, historical debates show that at least two dimensions of relations must be distinguished. On the one hand, measurable energy savings and, on the other, an emblematic stimulus of energy saving. The complexity of the issue made DST part of political decision-making processes as well as conflicting energy discourses. Thus, it became subject to historical change and structural conditions. It is by chance that DST was introduced directly after the so called 'second oil crisis' of 1979. Introducing it in Germany was not an energy emergency measure. In East Germany, officials judged

79 | Matthias Vogel: Energiewirtschaftliche Handlungszwänge in der DDR. Zu Möglichkeiten einer marktwirtschaftlichen Energieversorgung auf dem Territorium der DDR aus der Sicht internationaler Entwicklungstendenzen unter der Bedingung des Zusammenwachsens beider deutscher Staaten in den 90er Jahren. Berlin (East): Institut für Internationale Politik und Wirtschaft, 1990, 15. Cf. Riesner: Rationelle Energieanwendung, 48. 
DST as unsuitable despite its appeal as a planned economy of daylight. As a matter of fact, it seems as if the administrative view of energy was too technocratic to realize its potential as a tool of social engineering. In West Germany, after 1975 the political debate went beyond energy saving. Marginal savings were included into the argument to use a symbolic effect as a moment of energy saving. Its significance is part of the "high position that is assigned to energy saving today", as energy expert Schaefer put it. ${ }^{80}$ Here, DST can be interpreted as part of a process of social re-organization along the line of 'greening everyday life'.

If questioning time order is a sign of uncertainty, producing new securities must be seen as a complex process. Certainly, the process did not work out as a planning from above aiming at modernization and rationalization. In this sense, Illich's concept of 'energy addiction' is an oversimplification. The multiple ways daylight saving was connected to energy issues illustrate a tendency to 'energize' social debates. But DST is also closely connected to other key issues of the 1970s and 8os like 'individualization', 'leisure society', and 'quality of life'. Even if the aspect of energy saving is part of the public image of DST, it is important to see the limitations of such an approach. Everyday life soon gave way to a different incorporation of DST which was not anticipated in most of the governmental and parliamentary debates. Starting in 1980, people in East and West Germany developed a shared interest in the recreational value of daylight saving. "Most citizens have discovered that more daylight means that they can make a little more of their lives. Tennis fans and hobby gardeners appreciate the gift of an hour just like do-it-yourselfers, clandestine workers and fans of outdoor bars," wrote the Spiegel magazine. "East Germans, for example, use the longer summer evenings for extra car rides to the countryside [.]" ${ }^{\prime 1}$ The transformation of a discourse of economic crises and energy shortage into a momentum for quality of life is remarkable. Would DST have been accepted in a similar way without the 'side effects' of leisure and recreation? Its flexibility makes DST not only a widely accepted tool for social re-orientation, but also a fruitful subject matter for historians who want to understand the practices of social stability.

$\mathbf{8 0}$ | Ebersbach: "Sommerzeit", 498.

81 | “Weniger hitzefrei”, in: Der Spiegel, 01.09.1980, 104; “Verlorene Zeit”, in: Der Spiegel, 11.11.1980, 42. 
Daylight saving time as energy saving time is a myth. Not because its effects on energy consumption are questionable but rather because of the constructiveness of energy issues as a whole. In an impressive way the debates on daylight saving illustrate how societies discuss, constitute, and create energy problems. First, the legacy of DST as an emergency measure clearly calls for a historical contextualization. Its meaning and outcomes cannot be assessed timelessly. Second, the difficulties of judging its effect on energy consumption highlight the complexity of scientific and public concepts of energy and how this affects our views. Not only specific ways of using energy (as well as of using time) came into play, but geographic factors and energy infrastructure as well. Third, the decision-making process interfered with topics that - at first sight - bear no relation to energy policy. The political dimension of DST in divided Germany stresses this contextsensitive character. Energy issues were not simply instrumentalized for political reasons, both issues were durably interlinked. Forth, the overall picture of energy's social and cultural embeddedness has to include the dimension of social structures and mechanisms. The scope of action for DST was limited by the way energy saving discourses in East and West Germany related to their specific societal surroundings.

Combining these aspects, a historical perspective offers the possibility of understanding how energy policy and consumption are shaped by societal values, economic interests, and political choices (as by technology and available resources). ${ }^{82}$ It is not the job of an historian to judge the arguments for and against DST. It is more revealing why, when, and where they were uttered. Historians have to ask to what extent this constellation was open to historical change. The better we understand that it matters how we talk about energy, how we define its societal role, and how we conceptualize its materiality, the more we can judge and rate the scope and limitations of our contemporary decisions as consumers and citizens.

82 | Cf. Paul Sabin: “'The Ultimate Environmental Dilemma': Making a Place for Historians in the Climate Change and Energy Debates", in: Environmental History 15:1 (2010), 76-93. 


\section{References}

\section{Primary Sources}

Bischoff, Gerhard/Gocht, Werner. Das Energiehandbuch. $4^{\text {th }}$ ed. Braunschweig: Vieweg, 1981.

Bundesarchiv (BArch)

R 401, Reichswirtschaftsrat, no. 727.

R 3101, Reichswirtschaftsministerium, no.10361.

R 4701, Reichspostministerium, no. 207.

B 106, Bundesinnenministerium (BMI), no. 104135-104138.

B 136, Bundeskanzleramt (BKA), no. 18391.

DC 9, Presseamt beim Vorsitzenden des Ministerrates, no. 104.

DC 20, Ministerrat der DDR, no. 9438, 9579. no. I/4/3743.

DY 30, ZK der SED, no. 3020, no. J IV 2/2/1727, J IV 2/2/1860, J IV $2 / 2 / 1869$.

Bundesgesetzblatt, 1978.

Bundesministerium für Innerdeutsche Beziehungen, ed. Texte zur Deutschland-Politik, series II, vol. 7. Bonn: Deutscher Bundesverlag, 1981.

Bundesminister für Wirtschaft, ed. Energiebericht der Bundesregierung vom 24.09.1986. Bonn: Bundesregierung, 1986.

Deutscher Bundestag, ed. Energiepolitik im Deutschen Bundestag (7. und 8. Wahlperiode). Bonn: Deutscher Bundestag, 1980.

Deutscher Bundestag. Stenographische Berichte der Verhandlungen des Deutschen Bundestages, 1973-1978.

Ebersbach, K. F./Schaefer, H. “Sommerzeit und Energieeinsparung. Überraschendes Ergebnis einer detaillierteren Untersuchung: Es wird mehr Öl verbraucht”, in: Energiewirtschaftliche Tagesfragen 30 (1980), 496-98.

Franklin, Benjamin. "To the Authors of The Journal of Paris" (1784), in: Nathan G. Goodman, ed. The Ingenious Dr. Franklin. Selected Scientific Letters. Philadelphia: University of Pennsylvania Press, 1931, 17-22.

Gesetzblatt der DDR, 1977.

Hildebrand, Hans J. Wirtschaftliche Energieversorgung. $3^{\text {rd }}$ ed. Leipzig: Deutscher Verlag für Grundstoffindustrie, 1975.

Illich, Ivan. Energy and Equity. London: Calder, 1974. Download version: http://clevercycles.com/energy_and_equity, Accessed: 15.07.2011. 
Institut für Internationale Wirtschaft und Politik, ed. Energie- und Rohstoffprobleme im heutigen Kapitalismus. Berlin (East): Institut für Internationale Wirtschaft und Politik, 1978.

Kulturbund der DDR, ed. Energiepolitik und Kulturfortschritt. Berlin: Kulturbund der DDR, 1981.

Meyer-Abich, Klaus M., ed. Energieeinsparung als neue Energiequelle. Wirtschaftspolitische Möglichkeiten und alternative Technologien. München: Hanser, 1979.

Le Monde, 1976.

Müller, Werner/Stoy, Bernd. Entkopplung. Wirtschaftswachstum ohne mehr Energie? Stuttgart: Deutsche Verlags-Anstalt, 1978.

Neues Deutschland, 1979-1980.

Politisches Archiv Auswärtiges Amt (PA AA), Zwischenarchiv, no. 109.340, 122.339.

Reinhold, Otto. "Über die wachsende Dynamik unserer wirtschaftlichen und gesellschaftlichen Entwicklung”, in: Gesellschaftschaftswissenschaftliche Konferenz des ZK der SED, ed. Gesetzmäßigkeiten unserer Epoche - Triebkräfte und Werte des Sozialismus. Berlin (East): Dietz, 1984.

Riesner, Willi. Rationelle Energieanwendung. $2^{\text {nd }}$ ed. Leipzig: Deutscher Verlag für Grundstoffindustrie, 1982.

Der Spiegel, 1974-1980.

Traube, Klaus/Ullrich, Otto. Billiger Atomstrom? Wie die Interessen der Elektrizitätswirtschaft die Energiepolitik bestimmen. Reinbek bei Hamburg: Rowohlt, 1982.

Vogel, Matthias. Energiewirtschaftliche Handlungszwänge in der DDR. Zu Möglichkeiten einer marktwirtschaftlichen Energieversorgung auf dem Territorium der DDR aus der Sicht internationaler Entwicklungstendenzen unter der Bedingung des Zusammenwachsens beider deutscher Staaten in den goer Jahren. Berlin (East): Institut für Internationale Politik und Wirtschaft, 1990.

Die Welt, 1978.

Willett, William. The Waste of Daylight. London: Author, 1907.

Die Zeit, 1973-1980. 


\section{Secondary Sources}

Alexander, John/Schmidt, Joachim K. H. "Social Engineering: Genealogy of a Concept”, in: Adam Podgórecki/Jon Alexander/Rob Shields, eds. Social Engineering. Ottawa: Carleton University Press, 1996, 1-19.

Bartky, Ian R. One Time Fits All. The Campaigns for Global Uniformity. Stanford, CA: Stanford University Press, 2007.

Breuer, Barbara. Die Energiewirtschaft der Bundesrepublik Deutschland und der DDR im Vergleich. München: Oldenbourg, 1987.

Czakainski, Martin. "Energiepolitik in der Bundesrepublik 1960 bis 1980 im Kontext der außenwirtschaftlichen und außenpolitischen Verflechtungen", in: Jens Hohensee/Michael Salewski, eds. Energie - Politik Geschichte. Nationale und internationale Energiepolitik seit 1945. Stuttgart: Franz Steiner, 1993, 17-34.

Doering-Manteuffel, Anselm/Raphael, Lutz. Nach dem Boom. Perspektiven auf die Zeitgeschichte seit 1970. Göttingen: Vandenhoeck \& Ruprecht, 2008.

Downing, Michael. Spring Forward. The Annual Madness of Daylight Saving Time. Berkeley, CA: Counterpoint, 2009.

Etzemüller, Thomas. "Social engineering als Verhaltenslehre des kühlen Kopfes. Eine einleitende Skizze”, in: Thomas Etzemüller, ed. Die Ordnung der Moderne. Social Engineering im 20. Jahrhundert. Bielefeld: transcript, 2009, 11-40.

Friedrich-Ebert-Stiftung, ed. Die Energiepolitik der DDR. Mängelverwaltung zwischen Kernkraft und Braunkohle. Bonn: Verlag Neue Gesellschaft, 1988.

Geißler, Alfred/Riegert, Botho. Energiepolitik für eine lebenswerte Zukunft. Kohle contra Super-GAU. Bonn: Verlag Neue Gesellschaft, 1988.

Graf, Rüdiger. "Between National and Human Security: Energy Security in the United States and Western Europe in the 1970s", in: Historical Social Research 35:4 (2010), 329-48.

Hohensee, Jens. “Und sonntags wieder laufen... Die erste 'Ölkrise' 1973/74 und ihre Perzeption in der Bundesrepublik Deutschland", in: Michael Salewski/Ilona Stölken-Fitschen, eds. Moderne Zeiten. Technik und Zeitgeist im 19. und 20. Jahrhundert. Stuttgart: Franz Steiner, 1994, 175-96.

-. Der erste Ölpreisschock 1973/74. Die politischen und gesellschaftlichen Auswirkungen der arabischen Erdölpolitik auf die Bundesrepublik Deutschland und Westeuropa. Stuttgart: Franz Steiner, 1996. 
Karlsch, Rainer/Stokes, Raymond G. 'Faktor Öl'. Die Mineralölwirtschaft in Deutschland 1859-1974. München: Beck, 2003.

Krämer, Hans R. Die Europäische Gemeinschaft und die Ölkrise. Baden-Baden: Nomos, 1974.

Levine, Robert. A Geography of Time. The Temporal Misadventures of a Social Psychologist, or How Every Culture Keeps Time Just a Little Bit Differently. New York: Basic Books, 1997.

Michaelis, Hans. "Die Energiewirtschaft der Bundesrepublik Deutschland von 1970 bis 1990", in: Jens Hohensee/Michael Salewski, eds. Energie Politik - Geschichte. Nationale und internationale Energiepolitik seit 1945. Stuttgart: Franz Steiner, 1993, 51-74.

Prerau, David. Seize the Daylight. The Curious and Contentious Story of Daylight Saving Time. New York: Thunder's Mouth Press, 2005.

Rosa, Hartmut. Alienation and Acceleration. Towards a Critical Theory of Late-Modern Temporality. Malmö: NSU Press, 2010.

Schindelbeck, Dirk. "Wem die Stunde schlägt", in: Damals. Das Magazin für Geschichte und Kultur 32:4 (2000), 6-9.

Sabin, Paul. “'The Ultimate Environmental Dilemma': Making a Place for Historians in the Climate Change and Energy Debates", in: Environmental History 15:1 (2010), 76-93.

Schröter, Harm G. "Ölkrisen und Reaktionen in der chemischen Industrie beider deutscher Staaten. Ein Beitrag zur Erklärung wirtschaftlicher Leistungsdifferenzen”, in: Johannes Bähr/Dietmar Petzina, eds. Innovationsverhalten und Entscheidungsstrukturen. Vergleichende Studien zur wirtschaftlichen Entwicklung im geteilten Deutschland 1945-1990. Berlin: Duncker \& Humblot, 1996, 109-38.

Schüssler, Reinhard. Der Energieverbrauch der privaten Haushalte. Frankfurt/Main: Lang, 1987.

Stinglwagner, Wolfgang. Die Energiewirtschaft der DDR unter Berücksichtigung internationaler Effizienzvergleiche. Bonn: Gesamtdeutsches Institut, 1985 . 



\section{Energy Consumption Practices and Social Inequality}

The Case of Low-Income Households

Karl-Michael Brunner, Anja Christanell, Markus Spitzer

"Energy [...] penetrates significantly into almost all facets of the social world. Life-styles, broad patterns of communication and interaction, collective activities, and key features of social structure and change are conditioned by the availability of energy, the technical means of converting energy into usable forms, and the ways energy is ultimately used." ${ }^{1}$

This quotation clearly shows that energy is a basic requirement for social integration and social life, and that it is also tightly linked to social structure and power relations. Energy consumption is a manifestation and part of social stratification, and social inequalities often become evident in energy practices. Today's industrialised, high-tech societies - as opposed to societies of the past - are characterised by their energy-intensive ways of life.

Current lifestyles include patterns of consumption based on a high level of consumption of (finite) resources. For a long time, excessive consumption of energy was equated with social progress and modernisation. This equation, however, is increasingly being questioned as an effect of the rising awareness of the side-effects of the modern industrial era (climate change and exploitation of finite resources, for example). Meanwhile, a consensus about the non-sustainability of present energy systems has been reached, and the need for a transition to a 'low-carbon-society' is being affirmed.

1 | Eugene A. Rosa/Gary E. Machlis/Kenneth M. Keating: "Energy and Society", in: Annual Review of Sociology 14 (1988), 149. 
However, this transition can not only consist of ecological dimensions, but also has to include the social part of sustainable development and the question of "environmental justice" ${ }^{2}$, which plays an important role here.

In this context, analyses of the social differentiation of energy consumption are crucial because they shed light on patterns of social distribution and ways of appropriating the use of resources. This becomes relevant, especially politically, in the context of strategies for sustainability and fighting climate change (keyword: environmental justice). Up to now, connections between energy consumption, poverty and climate change have mainly been discussed in the context of global inequalities. ${ }^{3}$ Regarding the development worldwide, a trend towards imitation of Western lifestyles and consumption patterns can be identified in many developing societies, entailing an increase of energy consumption. ${ }^{4}$ It has to be kept in mind though, that massive global inequalities regarding energy still persist. On a global level, 1.4 billion people have no access to electricity, and another billion only has unreliable access. 3 billion people are dependent on biomass and coal for satisfying their basic needs. Each year, 2 million people (mainly women and children) die from indoor air pollution by household use of solid fuels, burning dung, wood, crop waste and coal in unventilated kitchens. For this reason, the UN defines energy access for the poor as a development priority. ${ }^{5}$

But also in industrialised countries, considerable differences in energy consumption exist to some extent. Although the industrialised lifestyle could generally be considered high in energy consumption, this generalisation disregards the social differences of energy consumption within this lifestyle. While (unlimited) availability of energy is the norm for some social groups in industrialised countries, other parts of society are faced with the problem of not being able to afford energy in sufficient

$2 \mid$ Horst-Dietrich Elvers/Matthias Gross/Harald Heinrichs: "The Diversity of Environmental Justice: Towards a European Approach”, in: European Societies 10:5 (2008), 835-56.

3 | Anthony Giddens: The Politics of Climate Change. Cambridge, UK: Polity Press, 2009.

$4 \mid$ Norman Myers/Jennifer Kent: The New Consumers. The Influence of Affluence on the Environment. Washington, DC: Island Press, 2004.

5 | United Nations Development Programme: Fast Facts. UNDP and Energy Access for the Poor. New York: UNDP, 2010. 
quantities or having to limit their use of energy services. To give an example: Even in European countries, deaths related to energy causes are not the exception because some people are not in a position to keep sufficiently warm in winter or to protect themselves from heat in summer. In the UK, for example, almost 30,000 people died from cold-related illnesses in $2007 / 08 .^{6}$

In recent years, the analytical focus has shifted towards inequalities and vulnerabilities in the Northern countries, bringing forward evidence that financially weaker households are more vulnerable to climate change (e.g. in periods of extreme weather conditions) than better-off households, although - compared to the more affluent - their contribution to climate change is usually lower (e.g. due to lower mobility rates). Different lifestyles are characterised by different impacts on the environment.7 In a study conducted in the UK, Angela Druckman and Tim Jackson point out empirical relations between lifestyles, energy consumption and carbon emissions. Referring only to income, they show that " $[t]$ he poorest $10 \%$ of households use, on average, only $43 \%$ of the energy used by the richest $10 \%$ of households [...] The poorest $10 \%$ produce, on average, $45 \%$ of the carbon dioxide generated by the richest $10 \%$." With regards to individual groups of lifestyles, Druckman and Jackson distinguish "fuel-rich" and "fuel-poor" households. The latter includes the socially deprived group of lifestyles which are "constrained by circumstances", who are most likely hit by fuel poverty, lying 21 percent below the UK mean for energy consumption and 20 percent below the mean for carbon dioxide emissions. Although socially less privileged groups in general have a lower consumption of energy (which actually could be considered as positive on the way towards a low-carbon society), their position on the energy market is feeble, i.e. in most cases they have to spend more on energy than households on a higher income (e.g. due to reminder fees because of delays in the payment of their bills). Moreover, they profit less from a liberalisation of the energy

6 | Brenda Boardman: Fixing Fuel Poverty. Challenges and Solutions. London: Earthscan, 2010, 168.

7 | Fritz Reusswig: Ökologie und Lebensstile. Frankfurt/Main: IKO, 1994.

8 | Angela Druckman/Tim Jackson: "Household Energy Consumption in the UK: A Highly Geographically and Socio-economically Disaggregated Model”, in: Energy Policy 36 (2008), 3183. 
market because they change their energy providers less frequently than households on a better income and thus often keep paying higher rates. ${ }^{9}$

In addition, socially less privileged groups are notably more frequently hit by fuel poverty. The definition of a fuel-poor household generally includes those which have to spend more than 10 percent of their income on energy to heat their home to an adequate standard. ${ }^{10}$ In the face of the complex interplay of rising energy prices, stagnant or decreasing incomes, high levels of unemployment, processes that multiply casualisation and the slow rate of redevelopment of residential buildings in terms of improving energy efficiency, the problem of fuel poverty has become increasingly urgent in recent years. Low-income and/or fuel-poor households are frequently incapable of satisfying basic needs such as heating their homes adequately. These groups of energy consumers are vulnerable to the consequences of insufficient or insecure access to energy.

It has been estimated that within the EU, between 50 and 125 million people are living under conditions of fuel poverty, and these figures are predicted to rise further in the near future. Social and political awareness for this problem, however, is still relatively low and varies considerably. ${ }^{11}$ From a scientific viewpoint, it is particularly obvious that there is a lack of studies investigating the matter from the perspective of the people concerned, focusing on their energy practices, conditions for action, and coping strategies. ${ }^{12}$ The project NELA (German acronym for "Sustainable Energy Consumption and Lifestyles in Poor and at-Risk-of-Poverty Households") takes exactly this stance, shedding light on energy consumption in lowincome and fuel-poor households in the Austrian capital Vienna.

Before discussing the results of the research project in greater detail, the following paragraphs shall elucidate the theoretical basis of the project, providing an outline of the understanding of energy consumption in social sciences.

9 | Boardman: Fixing Fuel Poverty, 90.

10 | Druckman: "Household Energy Consumption in the UK”, 3178.

11 Sergio Ernesto Santillán-Cabeza: Opinion of the European Economic and Social Committee on Energy Poverty in the Context of Liberalisation and Economic Crisis. Brussels: EESC, 2010.

12 | Boardman: Fixing Fuel Poverty, 174. 


\section{Social Science Perspectives on the Complexity of Energy Consumption}

For at least 40 years now, social sciences have been investigating energy consumption from various angles. In the 1970s, the energy crises raised awareness of questions about the development and the determining factors of energy consumption and efficiency. Consequently, the increased relevance of these questions also had an effect on energy consumption research; a scientific field which until this date had predominantly adopted a technical stance focusing on optimising efficiency. In the wake of the crises and subsequent to the discovery that identical households sometimes showed considerable differences in energy consumption, research started to include behavioural factors as well. It became increasingly evident that it is the people who consume energy, not their dwellings or devices. ${ }^{13}$

While research in this field had been dominated by psychological and economic approaches in the 1970s and 1980s, a genuinely sociological perspective started to prevail from the 1990 s onwards. The emphasis thus shifted to the socially mediated nature of energy consumption and its socio-technical and infrastructural embeddedness.

Analyses rooted in economic approaches usually centre on income and energy prices, resulting in the finding that income and energy expenses are directly related. In absolute numbers, increased income entails increased expenses for energy, while at the same time, the share of energy expenditure in the total consumption expenditure decreases. Low income households consequently spend a larger part of their income on energy. If the energy prices increase, therefore, this could have an accelerating effect on the development of energy efficient technologies or stimulate higher demand for and investment in energy saving devices and measures. However, this does not necessarily hold true for households on a lower income, which tend to answer increases in energy prices with changes in behaviour (e.g.

13 | Elizabeth Shove/Loren Lutzenhiser/Simon Guy/Bruce Hackett/Harold Wilhite: "Energy and Social Systems", in: Steve Rayner/Elizabeth L. Malone, eds. Human Choice and Climate Change. Vol. 2. Columbus, OH: Battelle Press, 1998, 293. 
reduced room temperature) rather than by investing in more efficient (but probably expensive) technologies or facilities. ${ }^{14}$

Along with income, other socio-demographic factors matter when it comes to evaluating energy consumption: For instance, a larger number of residents in a household signifies an increased energy consumption in total, while, at the same time, the per capita energy consumption decreases with growing size of the household. In fact, it has been stated that energy expenses also increase with the size of the dwelling. In terms of the differences between town and country, it has been shown that energy expenses are generally lower in urban areas with a higher population density.

(Socio-)psychological approaches offer insights into the relevance of factors other than economic ones, especially attitudes and values. However, it is debatable to which extent attitudes influence behaviour, as a large number of studies only discover small correlations between the two..$^{15}$

From the point of view of sociology, individualist models of behaviour within different economic and psychological theories are often critically judged, as they disregard the social embeddedness of actions, thus understating the intrinsically social nature of energy behaviour. The starting point for sociology when analysing (energy) consumption is always a social contextualisation of different states of consciousness and behaviour. In contrast to individualist theories derived from the fields of economy or psychology, these approaches do not limit explanations for the agents' behaviour and actions to conscious choices but also include preconscious and unconscious behaviour and routines. There is a variety of social practices in households (e.g. cooking, heating) which strongly determine energy consumption but which are based on the 'performance'

14 | Don D. Dillman/Eugene A. Rosa/Joye J. Dillman: “Lifestyle and Home Energy Conservation in the United States", in: Journal of Economic Psychology 3 (1983), 299-315.

15 | Karl-Werner Brand: "Social Practices and Sustainable Consumption: Benefits and Limitations of a New Theoretical Approach", in: Matthias Gross/Harald Heinrichs, eds. Environmental Sociology: European Perspectives and Interdisciplinary Challenges. Dortrecht: Springer, 2010, 217-35. 
of largely embedded everyday routines rather than being the result of conscious choices. ${ }^{16}$

It has frequently been pointed out in sociological research how deeply human behaviour is rooted in social milieus and lifestyles, and how social groups increasingly differentiate in the course of social change according to socio-cultural features they have in common. Attitudes and behavioural orientations should therefore be taken into account when analysing energy consumption, although this should not necessarily include a culturalistic de-valorisation of distinguishing social features. Orientations towards efficiency can differ widely among lifestyle groups, just as energy saving behaviour does. Therefore, different technologies can acquire various meanings, depending on their respective social contexts. According to their lifestyles, households thus display different behavioural patterns which can be termed distinctive "energy cultures."17

Energy use, in most cases, is invisible and not discussed, silently accompanying everyday actions and routines. Therefore, awareness for the factors determining energy consumption can only be raised if lifestylespecific ideas about what 'home' means (what is understood by comfort, a cosy atmosphere or hospitality), as well as their consequences in terms of energy (the 'right' lighting, a 'pleasant' room temperature) can be identified.

Apart from the internal social structure of a household, it is also the embeddedness of consumer behaviour in everyday life that needs to be investigated. The pragmatic, workaday life calls for viable solutions to the coordination of lives within time and space.

Patterns of consumption are also embedded in and influenced by social discourses about energy, the environment and poverty, just to name a few. These discourses, to a smaller or larger extent, determine the role models of our society, which in turn feed back into the legitimisation of certain patterns of consumption (cf. for example the public discussion about advantages and disadvantages of the prohibition of common light bulbs). In addition, it should be stressed that the scope of consumption could be limited, but also stretched by macro-structural trends in society (as, for

16 | Alan Warde: “Consumption and Theories of Practice”, in: Journal of Consumer Culture 5 (2005), 131-53.

17 | Margrethe Aune: “Energy Comes Home”, in: Energy Policy 35 (2007), 5457-65. 
example, individualisation), political, legal and economic frameworks, the structures of production and supply, or technological developments. ${ }^{18}$

Thomas Berker rightly points out that the technical aspects of energy use are frequently neglected in analyses originating in the fields of social sciences. ${ }^{19}$ One possible remedy could be a socio-technical approach, focussing on the dynamic interrelations between technology and everyday energy use and including the constructed environment and infrastructural and institutional frameworks as well.

All in all, it can be said that energy practices are influenced both by resources and restrictions determined by the respective living situation (e.g. income, size of dwelling, facilities) as well as by attitudes, values, social and cultural norms, ways of leading everyday life, technologies, the builtin infrastructure of homes, and the complex interrelations between all of these factors, which are in turn influenced by discourses, infrastructure, institutions and social trends.

\section{The NELA Project}

The aim of the project NELA is to investigate energy consumption in low-income households in the Austrian capital Vienna. ${ }^{20}$ The core of NELA is a comprehensive survey including qualitative interviews in 50 Viennese households afflicted by poverty. For purposes of comparison, ten more interviews were additionally conducted in better-off households. Research is based on the methodology of "Grounded Theory", which focuses on the systematic development of theories directly from the

18 | Karl-Michael Brunner: "Ernährungspraktiken und nachhaltige Entwicklung - eine Einführung”, in: Karl-Michael Brunner/Sonja Geyer/Marie Jelenko/Walpurga Weiss/Florentina Astleithner, eds. Ernährungsalltag im Wandel. Chancen für Nachhaltigkeit. Wien: Springer, 2007, 1-38.

19 | Thomas Berker: “Energienutzung im Heim als sozio-technische Praxis", in: Corinna Fischer, ed. Strom sparen im Haushalt. München: ökom, 2008, 175-92.

20 | The project is funded by the Austrian Climate and Energy Fund and is being administered by the Austrian Institute for Sustainable Development, in cooperation with the Institute for Sociology and Social Research at the Vienna University of Economics and Business, and the Wuppertal Institute for Climate, Environment and Energy. 
data. ${ }^{21}$ The interviewers used an open interview guide, complemented by a questionnaire for eliciting socio-demographic data and information on equipment and infrastructure of the households. The criteria for the selection of interview partners were based both in socio-demographic characteristics and in their adherence to significant groups at risk of poverty. The interviews were transcribed and analysed according to hermeneutic methods and computer-based, qualitative data analysis. On the following pages, selected results of the project will be described, focusing on energy-related housing and living conditions as well as on energy consumption practices.

\section{Housing and Living Conditions}

A large number of households display conditions of more or less severe austerity because of their low income. Often, debts, lack of provisions and economising as a way of life are the order of the day. Adopting a modest lifestyle in various dimensions is frequently a necessary long-term strategy in order to cope with the situation. Asked about desired changes in their housing conditions, the interviewees often show low demands in their responses. Answers include, for example, an additional room which can be used as a bedroom so as not to have to spend the night in the living room. This could be interpreted as a manifestation of their habitus of necessity or modesty, respectively. ${ }^{22}$

In recent decades it could be observed in numerous spheres of everyday life that the standards of what is considered normal with reference to energy consumption in our society have gradually increased (e.g. higher room temperatures, more marked hygienic standards, doing the laundry more frequently). Faced with these developments, many of the low-income households included in the survey react to the burdens they bear with a clear lowering of their living standards, adapting successively to conditions below the level of what would commonly be considered a 'normal' lifestyle. This becomes especially obvious in the case of people who have experienced a radical descent on the social ladder but are still trying to keep

21 | Anselm L. Strauss/Juliet Corbin: Basics of Qualitative Research: Grounded Theory Procedures and Techniques. London: Sage, 1990.

22 | Pierre Bourdieu: Distinction. London: Routledge, 1984. 
up their former standards of normality. On the long run, however, this venture is bound to fail. A comparative analysis shows that financially wellsituated households do not even think about some of the things that poor households already consider a luxury (e.g. heating all rooms of the house or taking a full bath). We will subsequently show that the subjectively perceived well-being is frequently adapted to a room temperature that is regarded as (apparently) financially affordable, not the other way round.

What is characteristic for many households is an attitude that already anticipates shortages and hardships. An unexpectedly high supplementary payment for energy costs, for instance, could severely exacerbate the often quite delicate financial planning - as much as a broken household device could cause great problems in coping with everyday life. Those who are tightly embedded in social networks (friends, family, social organisations) have less difficulty in managing their lives in precarious conditions and shortage of resources than those who cannot draw on these resources. Having recourse to supportive people or organisations is of immense importance as this can prevent grave consequences of any shortages that might occur (e.g. eviction or power cuts). However, feelings of shame frequently inhibit the activation of social networks.

The limited financial resources of most of the interviewees are also evident in their dwellings. The majority lives in blocks of council flats or similar blocks of flats for rent, in buildings that are often very old, badly insulated or not at all, with leaky windows and doors. Adverse conditions have a particularly strong impact when the flats cannot profit from 'coheating effects' of the neighbouring flats because of their location (ground floor, external walls). Altogether, the scope of action regarding energysaving practices is limited. Redevelopments of the housing stock are often delayed for years, especially in the case of private landlords, who see little need for immediate action. When redevelopments do take place, they are often welcomed by the residents, but also met with doubts and fears concerning possible rises in rent and running costs.

Income does not only limit the free choice of dwelling, but is frequently also reflected in household equipment and appliances. The furnishings and devices in most households at the lower scale of the income spectrum are often a mix of things - largely of a lower quality - that came with the flat, were acquired new or used, or were received as a present (mostly used). No matter how important a supporting social network may be, when it comes to household equipment it can help out in matters of basic fittings and the 
replacement of broken devices. Often, old or out-of-use devices are given to households with a low income. From an energy point of view, however, these are unintended 'Greek gifts', as they are often defective or prone to defects and energy intensive. Old household devices could even represent a safety hazard: If they are defective but are not replaced due to financial straits in the near future, makeshift solutions or workarounds representing a health hazard are opted for in some cases. Makeshift solutions also have to be accepted even in the case that functioning appliances cannot be used because of power cuts. 69-year old Ms Reisinger ${ }^{23}$, for instance, was forced to do the cooking with a gas camping cooker and 'lighting' her flat with a cheap, battery-driven camping torch for several months, as gas and electricity had been cut off in her flat. Short-term makeshift solutions, however, in some cases turn into long-term ones and become normality. When financial resources do allow the acquisition of new appliances, it is frequently the cheapest option that is purchased, implying less energy efficiency. In many cases, used devices are bought in second-hand shops or at flea markets, making the household fully functional again, but, on the other hand, also entailing diminished quality or additional repair expenses because of higher rates of failure.

For many households, high energy expenses or unexpected additional payments can cause tremendous difficulties. Even though different strategies are adopted in order to keep energy costs at a minimum and exploit every potential for economising, doubts always remain about whether the actions taken are really relevant to the problem. Frequently, they are due to a lack of feedback systems, as many of the people interviewed complained about the inability to evaluate their own attempts at saving energy. It is exactly in those households, however, that the interest in behaviour-related saving measures is particularly high, despite often already having reached the limits of their saving potentials. What remains as a source for feedback is only the annual statement, which often comes as a shock to the people interviewed - first and foremost in those cases where high additional payments jeopardise the already fragile financial management of the household. One of the major problems here is the large time gap between energy saving initiatives and the potentially resulting cost reduction. In fact, it is in most cases only the annual statement which shows whether the

23 | To safeguard the anonymity of the interviewees, fictitious names are used here. 
saving measures taken have been fruitful. Moreover, it is difficult to relate single practices to the energy consumption they entail. In some cases, a lack of monitoring in terms of consumption could even cause people to refrain from using some of the appliances in the household, trying to avoid estimated high energy expenses, and opt for a service provider instead. The following example of one interviewee serves to illustrate this point: Instead of washing his shirts at home, he engaged the services of a dry cleaner since the singular payment for this service seemed more reasonable to him than the accumulated energy use of his own washing machine.

Since the liberalisation of the energy market one possibility for lowering costs is changing the energy provider. But even though some of the interviewees considered such a change it was ultimately rarely carried out. Changes of this nature demand certain defined conditions, and therefore are considered to be high-involvement decisions. Apart from actively procuring information (some households are not equipped with internet access), physical and mental resilience as well as a systematic approach to the matter are required. However, these conditions are not always sufficiently present in low-income households. Moreover, considering the market power of some energy providers, some people doubt that an unproblematic change of providers is possible. Accounts by acquaintances about difficulties in switching the provider confirm this worry, and many interview partners complained about the lack of transparency of service charges.

Disconnections are the order of the day for some of the interviewees: More than a quarter of the people interviewed reported having been disconnected, sometimes more than once, from the power supply due to non-payment of arrears. Frequently, the debts are settled within a few days after disconnection and the services are restored. Sometimes, however, the financial crisis continues, and the household remains cut off from energy services. In the most extreme cases this situation could even last for several years. The problems disconnections cause are manifold: Besides the obvious direct consequence of having to cope without electricity and/or heating, a number of additional direct (e.g. fines and charges) and indirect (e.g. spoilage of foods) expenses resulting from this have to be taken into account in households which are considered poor or at risk of poverty. Subjective consequences like "feelings of shame", roused by the inability to afford a life in dignity with access to basic services, should be kept in mind here, too. 
The analysis of housing and living conditions yielded a number of contextual factors which affect energy behaviour in poor and at-riskof-poverty households. In the following paragraphs, empirical results focusing on two crucial energy practices will be discussed: heating and lighting. The central concern here is to describe the coping strategies ${ }^{24}$ the interviewees adopt in order to satisfy the basic needs for warmth and light in their constrained situation of limited financial resources and restricted housing and living conditions (which could even be aggravated by rising energy prices).

\section{Heating Practices}

From an economic perspective, people at risk of poverty should be saving on energy costs because of their financial situation. This would be a rationally replicable measure in reaction to rising energy prices concomitant with stagnant welfare benefits or incomes. But the real heating costs for any type of dwelling depend on a number of factors that are often beyond the reach of the interviewees, as, for instance, the cladding of the building and its windows, the heating system, the location of the flat within the house, the size of the living space, but also the severity of the winter season. Households at risk of poverty characteristically have drastically limited possibilities for investing in improvements, which is why coping strategies here mostly consist of user behaviour.

Within the sample of 50 interviewees, a large number of different coping strategies could be identified and divided into strategies for efficiency and strategies for sufficiency, both of which are characterised by low investments. Therefore, what could be termed efficiency strategies are low-cost investments which allow for increasing the efficiency of the dwelling (e.g. windows) or appliances (e.g. water-saving tops). They include sealing leaky windows and/or covering them with thick protecting curtains, or installing window blinds, all aimed at preserving heat.

All actions geared towards reducing energy consumption through cutbacks and sacrifices can be considered sufficiency strategies. Among

24 | The concept of 'strategy' is not used in the sense of a purposive-rational action in the following, but mostly to indicate more or less reflected ways of dealing with the matter. 
these strategies feature, for example, heating only the main living area or heating as little as possible during seasonal transition periods. Some of the people interviewed sat directly in front of the radiator in order to avoid loss of warmth. There were even cases of dwellings which had not been heated for several years.

In 21 of the 50 households included in the survey, the heating is turned on in only one room of the flat. This was found to be the most common coping strategy in order to reduce costs, especially in smaller flats, but was also observed in the case of larger ones. It mostly occurs when some of the rooms are not being used, or if the bedrooms are adjacent to the living room, and it is therefore sufficient to open the doors at night in order to facilitate heat circulation. This strategy is particularly popular because it permits to reduce the heating costs while at the same time still having one heated room.

In one third of the households, the cold part of the year also signifies having to put on various layers of clothing inside the house - that is, in most cases, at least two pairs of warm socks, sometimes even long underpants, and several layers of clothes on the upper part of the body. Being dressed like this provides warmth to people within the limits of their financial resources; however, it is rarely sufficient to reach the personal comfort temperature.

Another related strategy for coping with the cold inside the flat is 'slipping under the covers'. Six of the people interviewed claimed this to be part of their practices for enduring cold temperatures. As with all the coping strategies quoted, there are many different possibilities of interpreting these practices: For some, the thought of slipping under their favourite blanket is a pleasant idea; others might feel considerable mental strain having to accept that going to bed is their only choice for fighting the cold.

31 out of 50 households adopt one or more of these three strategic options aimed at lowering the heating costs.

Including technological factors into the analysis expands the horizon of a socio-economic point of view considerably. Frequently, households are not able to generate a pleasant room temperature despite the fact that they possess the necessary equipment. Ms Leitinger, for instance, is forced to regulate her storage heating meticulously in order to evenly distribute the accumulated heat throughout the day. On extremely cold days, turning up the heating would result in a cold flat later in the day because the heating 
would no longer be available after 4 p.m. Turning the heating down, on the other hand, would mean suffering from the cold during the day, but could at least stabilize the temperature at a lower level until the evening. Therefore, the heat stored by the technology used here is the determining factor for heating practices and coping strategies. Assuming that heating practices are not merely the result of individual rational decisions but are also influenced by processes of appropriation of the technologies in question, it can be asked how people actually reach an understanding of the functioning of the technology in place (e.g. heating, thermostat).

How this is dealt with shall be illustrated using the example of the accounting procedure for long-distance heating. The basic procedure here is as follows: Each radiator is equipped with an evaporimeter which measures evaporation. After the period of a year, the annual heat consumption is calculated on the basis of this data. Usually, this billing method does not influence heating practices. However, a number of the people interviewed try to comprehend this technology and the corresponding accounting method in more detail. Believing that the calculation is made for each radiator, even if it is not used, they deduce that their rate of fixed costs is too high. The truth is that fixed costs are calculated according to the size of the flat in square metres. Thus, in extreme cases, it can happen that radiators are dismantled or that the apartment is heated using only the minimum number of radiators in order to avoid evaporation on the others. This is based on the logic that fewer radiators produce lower heating costs. In the most extreme case, represented by Ms Milich, the flat is heated up to $28^{\circ} \mathrm{C}$ using two radiators in one room but none in the other rooms. This is thought to be an economical practice of heating, as several radiators remain turned off. What seems to be rationally justifiable from a subjective point of view though, can result in excessive energy costs. Often, reasoning and ideas other than economic ones can determine how people understand and appropriate technologies. Lay concepts about energy-related technology can play a major role in this. ${ }^{25}$

Heating practices are also affected by social norms. This was corroborated by the interviews, particularly regarding one point: the norm which decrees that nothing should be wasted. Regarding heating, this norm is largely binding for the majority of interviewees: If heating the entire

25 | Willett Kempton/Laura Montgomery: “Folk Quantification of Energy”, in: Energy 7 (1982), 817-27. 
apartment is regarded as wasteful (or a luxury) it is often avoided, even if it would be technologically and economically feasible. Concentrating the heat in one room is an indication of a habitus that centres on avoiding waste, which often had already developed in the interviewees' original family or has been acquired over years of living in conditions of poverty.

Apart from cost calculations, individual approaches to technology and habitual dispositions, it is also people's attitudes which influence heating practices. If, for instance, low income and high ecological awareness coincide, the chances are high that energy saving is a target, and it could even occur that ecological motives predominate. A comparative analysis of the 10 interviews conducted in households with a higher income (more than 6,000 Euro monthly) reveals that sufficiency is clearly not an issue for them and that efficiency strategies are markedly less developed here. The heating is left on until an agreeable comfort temperature is reached throughout the whole flat. Warmth represents the norm in these households and does not receive special consideration. For many households with a lower income, however, heating is an issue omnipresent in everyday life, at least during wintertime. Incertainties about the energy consumption being too high and looming consequences in the form of disconnections and energy debts are constantly present in many households. This does not apply to well-off households. In general, the people interviewed do not want to spend too much thought on heating. It simply has to function and should ideally be programmed to start in advance, so that the flat is already comfortably warm when they come home from work. The dwellings of households with a higher income represent an oasis of tranquility, relaxation, and a place for leaving behind stressful everyday realities. Being comfortable in this place is crucial, and heating practices are adjusted to facilitate this feeling of wellbeing. Investing in efficiency measures or forms of renewable energy is the exception to the rule among the group of people interviewed in this survey, although most of the heating systems are older and technically not up to date. It therefore follows that greater financial possibililties do not necessarily entail investments in the area of efficiency, even in the face of rising energy prices. 


\section{Lighting Practices}

There are a number of studies that predict a continuing rise of power consumption from residential lighting in the future. On the one hand, this is attributed to the rising number of different types of smaller households which means that energy consumption for lighting is increasing per person due to the disappearance of co-use; on the other hand, changing needs regarding lighting and forms of usage are to be held responsible. Up to the present day, however, hardly any studies have investigated the consumption of light from the consumers' point of view ${ }^{26}$, which is why the reasons for the rise still largely remain unknown.

As with heating practices, the example of illumination makes abundantly clear that energy consumption is characterised by an interplay of economic, social, cultural and technological factors. Lighting practices do not only depend on the location of the flat but also, for some part, on the seasons and times of the day and the resulting amount of daylight. According to the combination of these factors, the requirements for illumination can vary considerably. In the most extreme cases, a dense stock of trees in front of the window makes it indispensable to keep at least one source of lighting on when someone is present in order to allow for certain activities. The sample of interviews features a large number of dark dwellings, which entails an increased need for lighting.

Apart from the question of the availability of daylight, a large part of the requirements for lighting results from the necessities (factors for wellbeing) and activities of the inhabitants. If dimmed, indirect lighting is preferred for reasons of well-being and comfort; domestic tasks (reading, cooking, changing diapers, etc.) require different qualities and intensities of lighting. In this context, a large preference for brighter (and partly also more intense) light was noted; therefore, the ceiling lamp or frequently also additional sources of light are switched on.

Almost without exceptions, the results from this study prove the existence of a 'European' lighting culture, manifesting itself in the duality of the modes of illumination. 'European lighting culture' refers to the difference between 'brightness' and 'cosiness' with reference to lighting which has become apparent in intercultural studies. For example, the

26 | Mats Bladh/Helena Krantz: "Towards a Bright Future? Household Use of Electric Light: A Microlevel Study”, in: Energy Policy 36 (2008), 3521-30. 
differences between Japan and Norway that have been identified include a preference for one central source of light, suspended from the ceiling, which illuminates the room brightly in Japan, as opposed to a Norwegian preference for various smaller lamps spreading a feeling of cosiness. These cultural differences in lighting practices also have repercussions on the energy consumption: The consumption in Japanese households averages at 2.5 light bulbs per room; Norwegian households have an average of $9 \cdot 6 .{ }^{27}$

To cite one interviewee of our study, these dual modes could be termed "illumination for a purpose" and "atmospheric illumination", respectively. The first refers to central sources of light, mostly suspended from the ceiling, which illuminate the room and are mostly connected with brightness, immediacy, glaring or artificial and cold light; sometimes, they are compared to the ambience of offices and associated with the corresponding tasks and activities (work) which mostly require bright lights. "Atmospheric illumination", in contrast, provokes associations of decentralised sources of light, dimmed and indirect lighting, comfort, warmth, tranquillity, and romance. The latter form of lighting is in most cases perceived as being more pleasant and associated with ideas of a comfortable home. The results of the present study also corroborate that mood is a central factor for determining lighting practices.

The problem of the infrastructure available in the household, which is dated in many cases, also extends to lighting practices. Many of the people interviewed refer to light fittings that came with the flat or to lights they have become used to because they have been part of the household for a considerable stretch of time, and which are often seen as difficult to modify or regarded unsuitable for energy saving lights. Frequently, these fittings are chandeliers that are considered as having an extremely high consumption of power. However, even a source of light that has high-energy consumption, provokes aesthetic objections and is therefore perceived as problematic, can be integrated into the lighting practices within a prolonged process of domestication. ${ }^{28}$ It could even be integrated

27 | Harold Wilhite/Hidetoshi Nakagami/Takashi Masuda/Yukiko Yamaga: "A Cross-Cultural Analysis of Household Energy Use Behaviour in Japan and Norway", in: Energy Policy 24 (1996), 799.

28 | Thomas Berker/Maren Hartmann/Yves Punie/Katie J. Ward, eds. Domestication of Media and Technology. Maidenhead, UK: Open University Press, 2006. 
into the fittings of the dwelling, inhibiting changes. Preferences for sources of light integrated into the furniture are frequent, be it kitchen lights, the lighting of small bathroom cabinets, or the lights of a kitchen hood. They are either used as additional sources of light (in the evening) or as the only source of light (e.g. when using the toilet). Forming part of the inventory of the dwelling, they thus immediately suggest themselves for this use, even if they are extremely inefficient in their energy consumption.

Efficiency and sufficiency strategies could also be identified regarding lighting practices. Starting with sufficiency strategies, modesty regarding lighting becomes evident in many interviews, manifesting itself in accordingly adapted lighting. One strategy, for instance, consists of using the potentially available sources of light only selectively or not at all. Thus, chandeliers are sometimes only equipped with a part of the light bulbs (if some of these have broken over time they are not replaced) to dim the light. This could be attributed to economic reasons, but could also be related to the intensity of the light (too strong) in single cases. Some of the sources of light considered as having excessive energy consumption are only used scarcely or not at all (e.g. neon tubes). Moreover, using small lights instead of larger ones or generally reducing illumination (using light bulbs with less luminosity or only using one instead of many sources of lights) also belongs to these practices. In many households, the light emission from a TV set serves as the only source of illumination in the evening, justified with the argument of being sufficient for the activities that accompany watching TV. Another frequent practice is combining the light emitted by the TV set with a second, smaller source of light.

Some low-income households use candles as an additional or the main source of light - sometimes for reasons of reducing illumination, sometimes because of the warmth of the light they radiate, especially in winter.

Another strategy that is tightly linked to the respective heating practices consists in only lighting one room - in most cases, the main living room -, thus benefiting from the light for the adjacent rooms (e.g. the bathroom).

A further strategy, corresponding to the widespread norm of not wasting energy, is the practice of switching off the lights when leaving a room. This is a central practice especially in those cases where children are being trained to save energy. The parents in these cases in turn refer back to their own upbringing when explaining the roots of this attitude. Often, this practice is being taken for granted and considered to be an evidence 
of energy saving behaviour. However, some cases show the development of this attitude over time (e.g. in the case of a recent radical social descent) following a period of wasteful lighting.

Even if many of the people interviewed refer to more or less developed practices of reducing the lighting in their everyday illumination habits, there are many examples where a reduction is considered inadequate and a full illumination of the house is opted for. This seems to be the norm particularly in the presence of visiting friends or relatives: For visitors, the flat has to be bright and well-lit. Illumination, therefore, appears to be a way of showing respect, and brightness as opposed to saving money could be considered an indication of hospitality. ${ }^{29}$

Despite a considerably developed consciousness regarding energy, Christmas lights could be quoted as another example of abandoning the norm of reducing consumption. Installing these lights signifies being able to participate in cultural celebrations without restrictions, and therefore permits feeling like an integrated member of society. However, a minority of the interviewees appear not to reflect on their lighting practices in spite of their restricted conditions, nor do they show intentions of saving or identifying potentials for economising in their households.

With regard to efficiency strategies, it might be of interest to ask whether affordable 'minor investments' (e.g. energy saving bulbs) which contribute to raising energy efficiency are carried out despite limited financial resources. As the results of the study show, a fifth of the people interviewed already shifted to using mostly compact fluorescent lamps; three fifth changed at least partly to energy saving lights, and the remaining fifth does not use them at all. Consequently, more than three quarters of the households are already equipped with compact fluorescent lamps, which reveals a strikingly high tendency in low-income households towards saving energy through affordable investments.

The differences between low and high-income households that became apparent from the questionnaires about household appliances reveal that low-income households are generally already trying to operate on a low energy level and to implement many potential measures for saving energy. While households with lower incomes have 12 lamps on average (ranging between 2 and 34), better-off households own an averaged 32

29 | Harold Wilhite/Loren Lutzenhiser: "Social Loading and Sustainable Consumption”, in: Advances in Consumer Research 26:1 (1999), 281-87. 
lamps (ranging between 22 and 46 ). In low-income households, the share of energy-saving lights comprises 24 percent of the lamps used, whereas households on higher incomes only show 18 percent on average. Eight of the poorer households even use 100 percent compact fluorescent lamps, but this was not found to be the case in any of the better-off households in the current sample. Whereas other studies have explained the use of energy saving lights with motivations rooted in cost and environmental aspects ${ }^{\circ}$, the factors that clearly predominate in the impoverished households under investigation in the present study are mainly related to expenses.

\section{Conclusion}

The example of energy consumption in households with a low income and the problem of fuel poverty has served to illustrate the ways in which people from lower social classes deal with energy in the household and which difficulties rising energy prices, energy-inefficient dwellings and appliances as well as low incomes entail. Energy practices of better-off households were rudimentarily included for the purpose of comparison.

What is, then, the relevance of analyses such as these? From a social theory perspective the analysis serves to show how social inequalities become manifest in energy practices, contributing to the analysis of the connection between social differentiation and environmentally relevant consumption.

Politically, investigations of this kind are relevant in two ways: Firstly, policies and possible political measures for fighting fuel poverty could be deduced from the insights gained. The results of the NELA project clearly show that low-income and fuel-poor households are characterised by a number of energy burdens and related coping strategies. Regarding the structural framework, the factors that make households more vulnerable and are, at the same time, beyond the reach of their influence, were found to lie in inefficient construction features of buildings, heating technology and larger household appliances. Thus, if the structural framework mentioned here exerts a decisive negative influence on energy consumption and

30 | Rob Wall/Tracie Crosbie: "Potential for Reducing Electricity Demand for Lighting in Households: An Exploratory Socio-Technical Study", in: Energy Policy 37 (2009), 1021-31. 
well-being, any measures to be taken would have to start from there. The study at hand reveals that these households have great difficulties in tapping their full efficiency potentials due to the cladding of the building, the heating technology and the household equipment. Smaller and costneutral efficiency potentials are often already being exploited to a large part (for example, by using energy saving lights). For further measures, however, financial resources are often insufficient, even if there is a recognised need for greater efficiency in the building. It is exactly from this point that measures for raising the efficiency of buildings and tools could start, offering solutions that are ideally as cost-neutral as possible for the people concerned. On the long run, refurbishing the entire building would be the most efficient way of lowering energy costs and preventing fuel poverty. Besides long-term strategies like these, however, additional short-term measures to effectively combat fuel poverty are necessary. To name just a few: energy efficiency funds for the replacement of old devices, energy counselling tailored to the needs of fuel-poor households, a power-disconnection prevention system, and monthly energy bills. ${ }^{31}$ The proposed measures should, however, not be implemented separately and in an uncoordinated manner but integrated into a (national) strategy for the reduction of fuel poverty.

As mentioned in the beginning, these analyses are also politically relevant in relation to the question of managing the transition to a sustainable energy system and ecological as well as social equality. In the discussion on climate change, 'climate justice' is increasingly becoming a relevant topic. A further focus of attention is the differences between various population groups and regions in their contribution to climate change together with the fact that they are affected by the consequences in different ways. ${ }^{32}$ A study from Israel on energy consumption and use of cars by private households, for example, calculated that the Israeli

31 | For further details see Karl-Michael Brunner/Markus Spitzer/Anja Christanell: "Fuel Poverty. A Case Study of Vulnerable Households in Vienna/Austria", in: ECEEE, ed. Proceedings of the 2011 ECEEE Summer Study. Stockholm: ECEEE, 2011, 2057-68.

32 Robin Leichenko/Adelle Thomas/Mark Barnes: "Vulnerability and Adaptations to Climate Change", in: Constance Lever-Tracy, ed. Routledge Handbook of Climate Change and Society. London: Routledge, 2010, 133-51. 
population with the highest income produces emissions that are 25 times higher than those of the population with the lowest incomes. ${ }^{33}$

Sustainable politics should take these differences and related questions regarding the equality of distribution into consideration. It is necessary to test the effects of political tools (e.g. environmental taxes or trading systems) on socially and economically vulnerable groups in order to prevent pressure in the form of excessive costs on those which contribute less to the exploitation of resources anyway. In order for this to happen, however, it is necessary to obtain more data on energy consumption of different social groups.

To date, research on the socio-structural dimensions of energy consumption is still only fragmentary. In the face of the social challenges that climate change and the transition to a 'low-carbon society' entail, a more differentiated insight into energy practices of various social milieus and lifestyles is required. The project NELA has attempted to take a step in this direction.

\section{References}

Aune, Margrethe. "Energy Comes Home”, in: Energy Policy 35 (2007), 545765.

Berker, Thomas. "Energienutzung im Heim als sozio-technische Praxis“, in: Corinna Fischer, ed. Strom sparen im Haushalt. München: ökom, 2008, 175-92.

—. /Hartmann, Maren/Punie, Yves/Ward, Katie J., eds. Domestication of Media and Technology. Maidenhead, UK: Open University Press, 2006. Bladh, Mats/Krantz, Helena. "Towards a Bright Future? Household Use of Electric Light: A Microlevel Study", in: Energy Policy 36 (2008), 3521-30. Boardman, Brenda. Fixing Fuel Poverty. Challenges and Solutions. London: Earthscan, 2010.

Bourdieu, Pierre. Distinction. London: Routledge, 1984.

Brand, Karl-Werner. "Social Practices and Sustainable Consumption: Benefits and Limitations of a New Theoretical Approach", in: Matthias Gross/Harald Heinrichs, eds. Environmental Sociology: European

33 | Dan Rabinowitz/Carmit Lubanov: Climate Justice in Israel. Tel Aviv: The Association of Environmental Justice in Israel, 2011. 
Perspectives and Interdisciplinary Challenges. Dortrecht: Springer, 2010, 217-35.

Brunner, Karl-Michael. "Ernährungspraktiken und nachhaltige Entwicklung - eine Einführung“, in: Karl-Michael Brunner/Sonja Geyer/Marie Jelenko/Walpurga Weiss/Florentina Astleithner, eds. Ernährungsalltag im Wandel. Chancen für Nachhaltigkeit. Wien: Springer, 2007, 1-38.

Brunner, Karl-Michael/Spitzer, Markus/Christanell, Anja. "Fuel Poverty. A Case Study of Vulnerable Households in Vienna/Austria”, in: ECEEE, ed. Proceedings of the 2011 ECEEE Summer Study. Stockholm: ECEEE, 2011, 2057-68.

Dillman, Don D./Rosa, Eugene A./Dillman, Joye J. "Lifestyle and Home Energy Conservation in the United States", in: Journal of Economic Psychology 3 (1983), 299-315.

Druckman, Angela/Jackson, Tim. "Household Energy Consumption in the UK: A Highly Geographically and Socio-economically Disaggregated Model”, in: Energy Policy 36 (2008), 3177-92.

Elvers, Horst-Dietrich/Gross, Matthias/Heinrichs, Harald. “The Diversity of Environmental Justice: Towards a European Approach”, in: European Societies 10:5 (2008), 835-56.

Giddens, Anthony. The Politics of Climate Change. Cambridge, UK: Polity Press, 2009.

Kempton, Willett/Montgomery, Laura. "Folk Quantification of Energy”, in: Energy 7 (1982), 817-27.

Leichenko, Robin/Thomas, Adelle/Barnes, Mark. "Vulnerability and Adaptations to Climate Change", in: Constance Lever-Tracy, ed. Routledge Handbook of Climate Change and Society. London: Routledge, 2010, 13351.

Myers, Norman/Kent, Jennifer. The New Consumers. The Influence of Affluence on the Environment. Washington, DC: Island Press, 2004.

Rabinowitz, Dan/Lubanov, Carmit. Climate Justice in Israel. Tel Aviv: The Association of Environmental Justice in Israel, 2011.

Reusswig, Fritz. Ökologie und Lebensstile. Frankfurt/Main: IKO, 1994.

Rosa, Eugene A./Machlis, Gary E./Keating, Kenneth M. "Energy and Society”, in: Annual Review of Sociology 14 (1988), 149-72.

Santillán-Cabeza, Sergio Ernesto. Opinion of the European Economic and Social Committee on Energy Poverty in the Context of Liberalisation and Economic Crisis. Brussels: EESC, 2010. 
Shove, Elizabeth/Lutzenhiser, Loren/Guy, Simon/Hackett, Bruce/Wilhite, Harold. "Energy and Social Systems", in: Steve Rayner/Elizabeth L. Malone, eds. Human Choice and Climate Change. Vol. 2. Columbus, OH: Battelle Press, 1998, 291-325.

Strauss, Anselm L./Corbin, Juliet. Basics of Qualitative Research: Grounded Theory Procedures and Techniques. London: Sage, 1990.

United Nations Development Programme. Fast Facts. UNDP and Energy Access for the Poor. New York: UNDP, 2010.

Wall, Rob/Crosbie, Tracie. "Potential for Reducing Electricity Demand for Lighting in Households: An Exploratory Socio-Technical Study”, in: Energy Policy 37 (2009), 1021-31.

Warde, Alan. "Consumption and Theories of Practice”, in: Journal of Consumer Culture 5 (2005), 131-53.

Wilhite, Harold/Lutzenhiser, Loren. "Social Loading and Sustainable Consumption”, in: Advances in Consumer Research 26:1 (1999), 281-87.

Wilhite, Harold/Nakagami, Hidetoshi/Masuda, Takashi/Yamaga, Yukiko. "A Cross-Cultural Analysis of Household Energy Use Behaviour in Japan and Norway", in: Energy Policy 24 (1996), 795-803. 

Societal Perceptions of Energy Resources 



\title{
Cultural Meanings of Wood Gas as Automobile Fuel in Sweden, 1930-1945
}

\author{
HELENA EKERHOLM
}

Researchers within the social and human sciences have conducted several interesting historical studies on alternative fuels to petrol. ${ }^{1}$ Wood gas has not been given the same attention as a topic for scientific research ${ }^{2}$, despite the fact that wood gas was almost fully implemented in an automotive society, albeit for a short period of time. Although based on a variety of conceptual frameworks and theoretical terms, research on the history of alternative fuels refute the notion that technological failures have lost out due to a natural selection in which the better performer wins the race. What causes market dominance is not a clear-cut case of undisputed technological superiority or one-dimensional price issues. It is also not necessarily true that a new form of technology finds a market as soon as the necessary infrastructure is erected.

1 | Research for this article was funded by the Swedish Research Council Formas and was conducted within the programme The Fuel of the Future: A Research Programme on the Science, Technology and Selling of Biofuels in Sweden. I would like to thank my colleagues in this programme, readers and participants of the workshop 'Deified - Damned - Depleted: Energy as Resource, Symbol and Consumer Good' at the Deutsches Museum and for instructive comments on earlier manuscript drafts.

2 | For notable research on the history and user cultures of the electric vehicle see for example Michel Callon, Heidi Gjøen, Mikael Hård, Gijs Mom and David Nye. The steam engine automobile has been researched by e.g. Clay McShane, Mikael Hård and Andrew Jamison. Wood gas is currently researched by Camille Molles at L'Ecole des Hautes Etudes en Sciences Sociales, Paris. 
This article investigates the cultural meanings of wood gas as an automobile fuel in Sweden in the 1930s and during World War II. I will show how the proponents for wood gas as an alternative fuel for automobiles understated its socio-technical problems in order to achieve a politically motivated socio-technical change: a national fuel transition from petrol to domestic alternatives. This could not be realised without the practical user evaluations of a sufficiently large group of pioneer users. The second part of this article discusses how the cultural meanings of wood gas changed during World War II, as user problems known to the wood gas proponents of the 1930 s became common cultural goods. As has been shown by researchers of alternative fuels and of the automobile culture, personal transportation is more than the physical re-location from one place to another. It encompasses additional social values and symbolisms. It is therefore relevant to discuss the topic of wood gas in relation to the culture and ideals of an automotive age in formation. It is also interesting how the cultural meanings attached to wood gas related to those of other means of automotive propulsion, e.g. steam, electricity, petrol and ethanol.

Goods are neutral objects, but as an integral part of an information system goods communicate social meanings to consumers. Consumption is a ritual that takes place within and generates cultural patterns. Therefore the commodity under scrutiny must be analysed in relation to the social context in which it exists and is used. ${ }^{3}$ A problem of using consumption theories on the wood gas case relates to the definition of consumption as an act or ritual performed by a free agent driven by want or desire. ${ }^{4}$ This is true of wood gas use during the interwar years, whereas the wood gas case during the war years mainly was a matter of using wood gas as automobile fuel or not using an automobile at all. This makes wood gas a difficult commodity to make sense of from a consumption perspective, but it also raises the question of what happens to the cultural meanings of goods previously purchased and used through choice when these become more or less forced on consumers.

3 | Mary Douglas/Baron Isherwood: The World of Goods. Towards an Anthropology of Consumption. New York: Basic Books, 1979. Reprint, London: Routledge, 1996, 38-41, 44-45, 48-52; Arjun Appadurai: "Introduction: Commodities and the Politics of Value", in: Arjun Appadurai, ed. The Social Life of Things. Commodities in Cultural Perspective. Cambridge: Cambridge University Press, 1986.

4 | Douglas: The World of Goods, 36-37. 
In this article, I analyse wood gas as automobile fuel through policy ideals and praxis, technicians' (engineers and wood gas specialist mechanics) assessments of wood gas, user testimonies and symbolic associations. The source material includes public official archives from state boards responsible for wood gas related issues, governmental commissions, parliament and government. These volumes contain a variety of source material types, such as correspondence within authorities and with individual civilians, meeting protocols, commission statements, formal reports from referral bodies in the official and private sectors and news articles. Popular press material about wood gas has also been accessed through the archive at Tekniska Museet (National Museum of Science and Technology) in Stockholm. The source material includes wood gas instruction publications written for wood gas users in the civilian sector and wood gas publications by the Royal Swedish Academy of Engineering Sciences (Ingenjörsvetenskapsakademien).

\section{What is Wood Gas?}

Wood gasification technology is a British invention from the $19^{\text {th }}$ century. Initially, the technology was intended for industrial production, e.g. ironworks and smelting-houses. Stationary gasifiers were not compact enough to be used for fuelling vehicles but in the interwar years wood gasifiers for smaller, mobile internal combustion engines were developed. In Sweden, interest in wood gas as an automobile fuel arose in the $1920 \mathrm{~s}$ when engineer Axel Svedlund constructed the first Swedish automobile gasifier. ${ }^{5}$ Internationally, France and Germany were at the cutting edge, but wood gas as one of several alternative means of automobile propulsion also attracted interest in other nations with ambitions for fuel autarky, e.g. Italy, Switzerland, Yugoslavia, Lithuania, Austria, Hungary, the Soviet Union, Finland, Canada, Japan, Norway and India. ${ }^{6}$

5 | Ingenjörsvetenskapsakademien: Gengas. Svenska erfarenheter från åren 1939-1945. Stockholm: Generalstabens litografiska anstalts förlag, 1950, 1-3. 6 | Gasgeneratorkommittén, Delbetänkande, 09.12.1937, 9-12, in: Jordbruksdepartementet, konselj 56, 12.03.1938. Riksarkivet (National Archives, Sweden), henceforth abbreviated RA. 
In simple terms, the wood gasifier produced combustible carbon monoxide gas, which was used to fuel internal combustion engines adapted for petrol. The gasifier could be fuelled with wood, peat or charcoal. For the sake of simplicity, I will use the term wood gas when referring to vehicle fuel gasification regardless of gasifier fuel. Because private individual automobility was limited during the investigated time period, especially during the war years, the driving and maintenance of wood gas vehicles was mainly an activity performed by professional bus and taxi drivers and repair shop personnel. Wood gas was also widely used within the military sector, but this paper's main focus is the civilian sector.

Domestic automobile fuel alternatives were interesting for Swedish politicians because oil production, and consequently petrol, had two globally universal problems: Its import was sensitive to international crises and in peacetime there were considerable concerns about the depletion of oil reserves.7 During the interwar years, contemporary observers witnessed a steadily expanding automotive fleet. Due to the ever increasing importance of the various types of motorised vehicles, combustible oils became indispensable. ${ }^{8}$ Sweden is a nation without direct access to oil reserves, a problem which needed to be addressed as the transport sector grew in importance. Political measures were directed both at developing domestic fuel alternatives and at controlling oil import.9

\section{SUPPORTING THE FORESTRY INDUSTRY OF NORTHERN SWEDEN}

Wood gas did not arouse much interest among elected officials until a crisis struck the expanding forestry industry. Early in 1930, a member

7 | Bosse Sundin: “Från avfall till möjligheter. Etanol i början av 1900-talet”, in: Polhem. Uppsala: Svenska nationalkommittén för teknikhistoria, 2005, 72-74.

8 | Axel F. Enström: “Motorproblemet inom automobilindustrien”, in: Teknisk tidskrift: Automobil-och motorteknik, 16.04.1938, 25.

9 | Thomas Jonter: Socialiseringen som kom av sig: Sverige, oljan och USA:s planer på en ny ekonomisk världsordning 1945-1949. Stockholm: Carlssons, 1995, 13, 98-103, 140-42; Erland Mårald: "Methanol as Future Fuel: Efforts to Develop Alternative Fuels in Sweden after the Oil Crisis", in: History and Technology 26:4 (2010), 335-36, 341-42, 349; Sundin: “Från avfall till möjligheter”, 72-74. 
of parliament called into question the social situation of workers in the region of Norrland. Considered an important supplier of natural resources, this geographical area of Sweden was an industrially and economically expanding region, but it had been afflicted by reduced production and industry close-downs at the end of the 1920 s. $^{10}$ For the sake of general nationwide economic progression the state had to intervene. A governmental commission - in short called Skogssakkunniga and mainly consisting of leading figures within the forestry industry and its labour unions - was appointed to investigate how this could best be done. The commission's task was to propose policy measures for increasing the sales of domestic forestry products, predominantly from the northern regions, thereby increasing profits and creating employment opportunities." Skogssakkunniga was part of larger policy crisis deliberations including social politics and the elimination of poverty. The progress of society stood in direct relation to the state of domestic industries, of which forestry had emerged as a cornerstone.

A possibility was the automobile fuel market, as forestry could provide two promising fuel alternatives: wood gas and sulphite ethanol, both based on the profitable utilisation of forest product waste. Gasifiers could be fuelled with poor quality timber and brushwood while sulphite ethanol was derived from sulphite lye waste from pulp and cellulose production. Market stabilisation of these two fuels would be a step towards two important goals: national self-sufficiency and an expansion of one of the nation's most important industries. ${ }^{12}$

The commission engineers also listed negative aspects of wood gas usage: poor hill-climbing and acceleration capacities, consistently lower speed and inconvenient user procedures such as refilling and emptying the gasifier. The lower engine effect and thermal value of wood gas compared with petrol could be parried by an increase in the engine's compression. Thus, the engine effect was not considered to be affected to a degree that would disqualify wood gas as an important fuel, especially considering that fuel costs with wood gas would be reduced to 70 percent of the price of petrol in 1932. Appropriate wood gas users were state authorities, boards of

10 | Parliamentary bill 1930:38, second chamber.

11 | Parliamentary bill 1930:38, second chamber, 17; SOU 1933:2. Stockholm: Jordbruksdepartementet, 1933, 9, 15.

12 | SOU 1933:2, 164-72, 180, 186. 
road administration and farmers with adjoining forestry from which cheap gasifier fuel was easily accessible. ${ }^{13}$

In some parts of the report, the commission expressed optimistic hopes and visions for the future establishment of wood gas as a fuel, at least for the users mentioned above. But optimism seems to have been rhetorical. Although presenting measures for promoting increased wood gas usage, the commission made specific mention of a prevailing opinion among engineers that the technological development of charcoal gasification fuelling had not made significant progress, neither in Sweden nor abroad, during the preceding years. Nevertheless, nationalist incentives to improve national finances and diminish dependence on imported petrol motivated the introduction of a gasifier loan fund, which could aid civilian gasifier investments. The idea behind introducing gasifier loans was to achieve more widespread wood gas use without spending too much public means on a form of technology in its experimental phase. The consequence was that large costs and risks of politically desirable socio-technical change were transferred to private sector companies and some individual motorists. ${ }^{14}$

Wood gas technology was new and untried and could prove to be a risky investment, especially for farms and businesses that had felt the blow of financial crisis in the early 1930s. To sweeten the deal, the commission argued that the terms and interests of the loan should be especially favourable in order to attract loan applicants. This included compensation for expected infrastructural problems, as the commission suspected that access to charcoal briquettes would become difficult for wood gas pioneers. ${ }^{15}$ If prematurely introduced and promoted, gasifiers could become labelled a bad investment whose teething problems would become symbolically confirmed as unavoidable socio-technical characteristics.

In order to avoid negative wood gas associations among prospective users, loan stipulations were designed to counteract unreflected investments. Due to uncertainties regarding quality, loan applications had to be approved by technical experts within academia. A market overflowing with badly functioning gasifiers would, according to the commission, fail to produce the desired effect: the continuing development of wood gas technology. The loan fund was also designed in accordance with

13 | SOU 1933:2, 94-95, 183, 186, 190.

14 | SOU 1933:2, 185, 187, 190; Governmental bill 1932:212, 11, 15, 17.

15 | SOU 1933:2, 187-89. 
nationalist sentiments. Eligible loan applicants were Swedish citizens in sound economic circumstances and joint-stock companies who wished to purchase a charcoal-fuelled gasifier for use within the country. The latter condition was stipulated in accordance with the proposal's main aim, namely to promote national industry through increasing sales of domestic timber and job opportunities within Sweden. ${ }^{16}$

\section{ImMEDIATE Disappointment}

Initially, the loan fund seemed successful. After its introduction in 1932 gasifier manufacturer $\mathrm{AB}$ Gasgenerator received 250 orders for gasifiers, compared to 57 orders placed during the six months preceding the introduction. Interest had been so considerable that demand had surpassed supply, causing delivery problems. ${ }^{17}$ Due to high consumer demand, an additional 500,000 SEK (approximately 15 million SEK of today's value) was added to the loan fund for the budget year of $1933 / 1934 .^{18}$

During the same time period, however, dissatisfied wood gas pioneers dismantled their gasifiers. Low fuel effect, questionable dependability, few wood gas education opportunities for the users, inferior service and difficulties in acquiring charcoal put wood gas at a disadvantage. In 1932, 201 wood gas automobiles were in use. Gasifier producers received orders for an additional 672 gasifiers. Almost all of these orders were cancelled within a year. Approved gasifier loans dropped from 225 in 1933, to four in 1934 and 1935 respectively. In 1936, no loans at all were extended and in 1937 only a single loan was approved. The 500,000 SEK that had been added to the loan fund budget in 1933 were therefore not utilised. ${ }^{19}$

The loan fund fiasco illustrates a discrepancy between policy anticipations on the one hand and user experience on the other. More than double the original loan fund sum was added for a budget year

16 | SOU 1933:2, 1933, 187, 189.

17 | SOU 1933:2, 94-95.

18 | Parliamentary communication 1933:210. Money value recalculation through the National Museum of Economy's online re-calculator. http://www. myntkabinettet.se/web/Hem.aspx, Accessed 01.01.2011.

19 | Gasgeneratorkommittén, Delbetänkande, 09.12.1937, 13, 16, 28, in: Jordbruksdepartementet konselj 56, 12.03.1938, RA. 
when user interest dropped to near insignificancy. Wood gas had seemed promising but optimism was swayed by user discontent. For government politicians and high-ranking military officials the fuel issue was no less important than it had been in 1932. Another governmental commission (Gasgeneratorsakkunniga) was initiated in 1937 to examine how wood gas users could overcome their strained relationship with the new technology. Just as in 1932, the well-being of the Swedish forestry industry was an important factor in 1937. However, the main objective behind appointing Gasgeneratorsakkunniga was to safeguard military preparedness. The mission was to investigate the technical and economic preconditions for the wider use of wood gas for vehicles and how to guarantee sufficient production of gasifiers in peacetime - creating an infrastructure that would ease a fuel transition should war break out. Sulphite ethanol fuel was briefly addressed as a potential petrol surrogate but then dismissed, since it could not be produced in satisfactory amounts. Wood gas was deemed a more reliable surrogate fuel in both civilian and military sectors. ${ }^{20}$

Although the views regarding the usability of wood gas had changed, the commission saw questionable loan benefits and infrastructural problems as more plausible explanations for the loan fund failure. Infrastructures had been insufficient: no streamlined industrial production of gasifiers, too few education possibilities for wood gas user and inefficient charcoal distribution. Also, the price of charcoal had risen, increasing fuel costs by 40 percent in 1937 compared with 1932. Choosing wood gas over petrol was thus no longer a cost-saving measure for the user. ${ }^{21}$

During their investigations, the Gasgeneratorsakkunniga commission received letters expressing a variety of opinions from the wood gas pioneers of 1932. One factory owner claimed he had been fooled into the most deplorable investment he had ever made. After his chauffeur quit his employment in refusal to use wood gas, the factory owner had dismantled the gasifier and urged the state to cover the expenses he had incurred for

20 | Gasgeneratorkommittén, Betänkande, 08.07.1939, 6-8, in: Jordbruksdepartementet, konselj 58, 29.09.1939, RA; Gasgeneratorkommittén, Delbetänkande, 09.12.1937, 7. Jordbruksdepartementet, konselj 56, 12.03.1938, RA.

21 | Gasgeneratorkommittén, Delbetänkande, 09.12.1937, 25, in: Jordbruksdepartementet, konselj 56, 12.03.1938, RA. 
trying out wood gas. ${ }^{22}$ Experiences with unsuccessful wood gas usage had caused loan takers difficulties. Not only had gasifiers of questionable quality and durability been a bad investment. Some loan takers had incurred additional costs brought about by engine failure. ${ }^{23}$ After four years of using the Svedlund gasifier, another company compared wood gas usage to that of Lättbentyl (a 75 percent petrol and 25 percent ethanol blend fuel), arriving at the conclusion that the truck fuelled by wood gas had required two weeks longer repair service than the Lättbentyl-fuelled counterpart. Not only had maintenance been more time-consuming, the wood gas fuelled vehicle had a lower average speed than the vehicle fuelled by the petrol-ethanol blend. ${ }^{24}$

\section{New Evaluations}

Early accounts of user experiences were deemed subjective and unreliable by Gasgeneratorsakkunniga, who effected systematic user evaluations by equipping ten test groups within state road administration and private sector companies with wood gas vehicles. Usage was regularly documented and evaluated by users and the commission alike. ${ }^{25}$ Although some deemed wood gas user-friendly and reliable ${ }^{26}$, commonly reported operational problems included user inconvenience, poor effect due to moist charcoal, burnt soot filters and nozzles and starting difficulties. For two test groups, burnt soot filters and a faulty rubber packing led to severe engine failures requiring thorough repairs since soot and small gravel had leaked into the system. More dramatic examples of operational problems were carburettor fires due to gas accumulation under the engine bonnet prior

22 | Letter from Oscar Rylander, 04.03.1937, in: Gasgeneratorkommittén 1937, RA.

23 | Statement from Kommerskollegium (National Board of Trade), 2-3, in: Gasgeneratorkommittén 1937, RA.

24 | Letter arrived 26.04.1937, 2, in: Gasgeneratorkommittén 1937, RA.

25 | Gasgeneratorkommittén, Delbetänkande II, 07.02.1939, 3, in: Jordbruksdepartementet, konselj 58, 29.09.1939, RA.

26 | Letter dated 04.08.1937, 1-3, in: Gasgeneratorkommittén 1937, RA; Gasgeneratorkommittén, Betänkande, 08.07.1939, 9, in: Jordbruksdepartementet, konselj 58, 29.09.1939, RA. 
to gasifier ignition, and an explosion in a gas purifier. Roughly half of the difficulties could be repaired in only one or two hours by the driver, but the commission stated repeatedly that wood gas usage required knowledgeable and interested drivers, whose patience would not be strained by frequent small repairs. ${ }^{27}$

Despite this, the commission stated that technological development had advanced to a point where wood gas was a satisfactory surrogate fuel. ${ }^{28}$ In peacetime, wood gas was not a fuel technology that would replace petrol for all types of automobility, but it would serve the needs of certain user groups and sectors. Usage preconditions included a high total vehicle weight, sufficient engine cylinder volume and continuous long distance driving with few stops. It was concluded that wood gas was best suited for heavy trucks used for long transports of approximately 200 kilometres and ten hours of driving, during which gasifier maintenance was said to possibly constitute a welcome break. ${ }^{29}$ The availability of qualified service personnel also made the military sector a potentially appropriate wood gas consumer. ${ }^{30}$

\section{World War II - The Wood Gas Era}

The outbreak of World War II finally brought the wood gas issue to the fore. Not only had the total number of civilian vehicles increased; the armed forces were also highly dependent on motorised transportation. In the autumn of 1939, political efforts endeavoured to smoothen the transition from petrol to wood gas by addressing infrastructural problems. A state

27 | Gasgeneratorkommittén, Delbetänkande II, 07.02.1939, tabell III:1-12, in: Jordbruksdepartementet, konselj 58, 29.09.1939, RA; Gasgeneratorkommittén, Betänkande, 08.07.1939, 22a, in: Jordbruksdepartementet, konselj 58, 29.09.1939, RA.

28 | Gasgeneratorkommittén, Betänkande, 08.07.1939, 30, 62, in: Jordbruksdepartementet, konselj 58, 29.09.1939, RA.

29 | Gasgeneratorkommittén, Delbetänkande II, 07.02.1939, 20, in: Jordbruksdepartementet, konselj 58, 29.09.1939, RA; Gasgeneratorkommittén, Betänkande 08.07.1939, 22a, in: Jordbruksdepartementet, konselj 58, 29.09.1939, RA.

30 | Gasgeneratorkommittén, Delbetänkande, 09.12.1937,32-33, in: Jordbruksdepartementet, konselj 56, 12.03.1938, RA. 
wood gas board, Gengasnämnden, was set up to further the technical advancement of wood gas. To streamline its related trade, the statecontrolled Svenska gengasaktiebolaget was launched in the summer of 1940 to distribute and supervise the trade of wood and charcoal. ${ }^{31}$

Gengasnämnden stated that operational disturbances and high conversion costs put motorists off wood gas. The only factors that could make motorists use wood gas were a state forced fuel shift and the threat of Swedish capital disappearing to foreign petroleum interests. However, Gengasnämnden did not want to present drastic measures to achieve a fuel transition through scare tactics. Instead, endeavours were aimed at making a transition attractive to consumers by solving immediate problems such as the insufficient gasifier fuel distribution and hazards linked to technical flaws. Potential wood gas users would be won over with tax exemptions. ${ }^{32}$ Another issue was the plethora of different gasifiers. ${ }^{33}$ Streamlining and rationalising all levels of wood gas infrastructure was essential for a largescale wood gas launch.

With the occupation of Norway and Denmark in the spring of 1940 , the primary import routes of petrol to Sweden were cut off. Petrol import dropped dramatically, forcing a fuel transition from petrol to wood gas. ${ }^{34}$ Fuel ethanol and shale oil were reserved for emergency rescue automobiles and some military vehicles, whose purpose disallowed time-consuming maintenance and starting procedures. Electric propulsion was used to some extent for remodelled petrol-fuelled internal combustion engine trucks operating in city traffic and for motorcycles. Approximately 16 percent of all heavy motorcycles in 1942 and 1943 were electric. ${ }^{35}$ But wood gas was the primary automobile fuel.

31 | Governmental bill 1940:298.

32 | Protocol 21.12.1939, 1-2, 4, 6, in: Gengasnämnden, vol. A1. Statens bränslekommission (1940), RA; Protocol No. 27 23.11.1939, appendix C, 1-5. Gengasnämnden, vol. A2. Statens bränslekommission (1940), RA; Governmental bill 1940:298, 12.

33 | Governmental bill 1940:298, 12.

34 | Protocol 2.11.1944, 7, in: Drivmedelsutredningen 1944, vol. 3, RA; Kommerskollegium: Sveriges offentliga statistik, handel.

35 | Bevillningsutskottet (the Committee on Supply), report 1945:33, 2; Pär Gierow: “Svenska erfarenheter av elbilen", in: Teknisk tidskrift, 18.05.1946, 485, 490, 493. 
Switching to wood gas was no longer a matter of choice; it was a necessity for those wanting to continue to use an automobile. Although bus and truck transportation was maintained at a level close to that prior to the war, the number of registered civilian passenger cars dropped from circa 180,000 in 1939 to circa 32,000 in $1941 .^{36}$ In only one year, from 1940 to 1941 , the number of civilian wood gas vehicles increased from 9,141 to 68,872 . In 1943 , it peaked at 73,853 wood gas automobiles, constituting around 90 percent of the land-bound civilian motorised transportation in Sweden. ${ }^{37}$

A substantial number of passenger car owners did not acquire gasifiers, but deregistered their vehicles, putting them out of operation. This is not necessarily proof of widespread antipathy towards wood gas. It could also be a result of infrastructural problems. Moreover, purchasing a gasifier caused additional expenses that the ordinary household might not have been prepared to prioritise in times of crisis, unless individual automotive transportation was of vital importance. During the interwar years, private ownership of passenger cars and motorcycles was a luxury enjoyed by only a minority of the Swedish population. The outbreak of the war further diminished this minority. It is possible that the cultural perceptions of wood gas were affected not only by the practical issues linked to driving a wood gas fuelled automobile, but also by the fact that the majority of passenger car and motorcycle owners could not use their vehicles at all. Wood gas perception was effected by the experience of enforced privation that was characteristic of wartime consumption restrictions in general.

Although there were still infrastructural problems such as limited access to gasifier fuel ${ }^{3}$, wood gas was now the fuel that upheld motorised transportation on a diminished scale. Initially, contemporary observers were optimistic regarding the future of wood gas (Fig. 1). Although technically a wartime surrogate, the widespread usage was seen by enthusiastic optimists as the breakthrough of wood gas that would carry over into peacetime. If and when petrol returned, wood gas would retain

36 | Statistiska centralbyrån: Statistisk årsbok för Sverige. Stockholm 19241940, 1949.

37 | Ingenjörsvetenskapsakademien: Gengas, 10; Motormännens Riksförbund: Motormännens gengasbok. Stockholm 1940. Reprint, Stockholm 1941, 12-13.

38 | Parliament communication No. 93, of the extraordinary session of the Riksdag, 1940. 
a market niche. The crisis meant an opportunity for wood gas to prove its worth for users sceptical towards new technologies. ${ }^{39}$

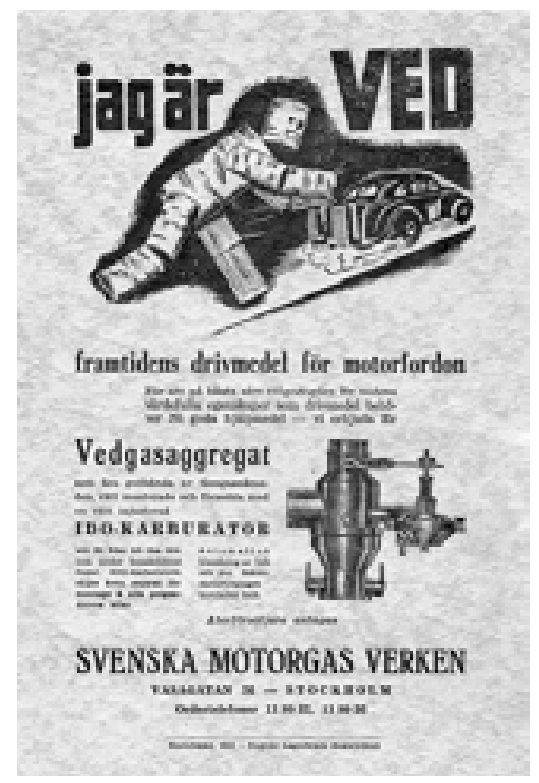

Figure 1: "I am Wood. The Automobile Fuel of the Future." During the first war years, advertisements for Swedish gasifier manufacturers expressed optimistic expectations of a bright future for wood gas usage.

39 | See for example "En knuff framåt", Aftonbladet 24.09.1940; "Gengasens definitiva genombrott i Sverige", Aftonbladet 16.11.1940; "Gengasen surrogat eller framtidens motorbränsle?", Aftonbladet 12.11.1940; “Gengasen är här för att stanna!", Gengas-journalen (special edition of Vecko-journalen) 17.11.1940; Motormännen: Motormännens gengasbok, 7, 63; “Jag tror på gengasen...", Biljournalen No. 2 1940, 3; “Se till att ni köper ett godkänt aggregat!”, Biljournalen No. 2 1940, 10; “Philipsons står rustat!”, Biljournalen No. 2 1940, 24. Bränsletekniska kommittén vid Ingenjörsvetenskapsakademien: Gengasdagen 8 juni 1943: Meddelande och diskussionsinlägg, Meddelande $n r$ 15, 1943, 3. 


\section{HAZARDS}

One of the most defining negative user associations of wood gas was danger, specifically in the forms of fire and poisoning. Between 1939 and 1944, 2,865 wood gas related fires were reported. The fire frequency was at its highest during the first two years of widespread wood gas usage, before fires caused by erroneous technical design were averted as lessons learnt led to new safety regulations.

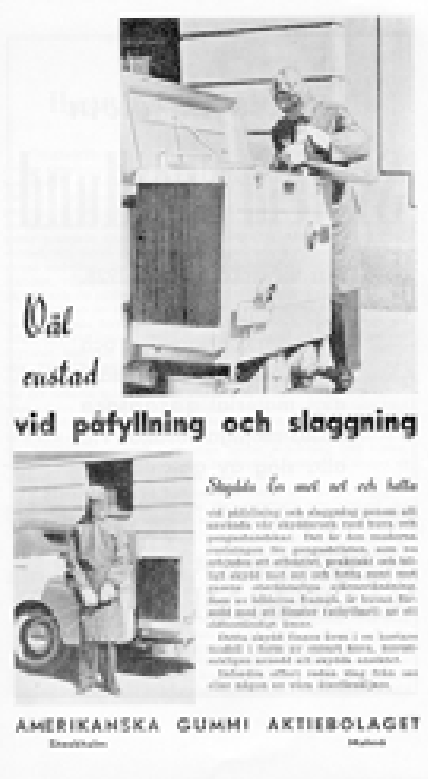

Figure 2: "Well Equipped during Gasifier Emptying and

Refilling. Protect Yourself against Soot and Heat." Due to the unpredictability and hazard associated with wood gas usage, protective gear was marketed, although with questionable success.

Gengasnämnden received several reports of flames shooting out from open gasifier fuel filling shutters, inspection hatches and ash container shutters, leading to burn injuries on the arms and faces of those standing 
in front of shutters. ${ }^{\circ}$ To avert fires caused by careless gasifier cleaning, locations especially assigned for emptying gasifiers were decreed. Wood gas fuelled automobiles had to carry fire extinguishers and a ten litre vessel for emergency fire extinguishing. Fires ascribed to the human factor also declined as users became more adept through practical experience (Fig. 2). ${ }^{41}$

Another hazard connected to wood gas usage was acute and chronic carbon monoxide poisoning. Emissions from petrol-fuelled cars consisted of 6-7 percent carbon monoxide, compared with 20-30 percent for wood gas. When inhaled, even in small doses, carbon monoxide blocks the blood cells' absorption of oxygen, causing suffocation. In 1940, 6o cases of wood gas induced acute carbon monoxide poisoning became known, seven of which resulted in death. The following year the number of known cases had increased to 901 (17 deaths) and 1,135 (eleven deaths) in $1942.4^{2}$ During the war years, carbon monoxide poisoning was so strongly associated with wood gas usage that it often was referred to as wood gas poisoning, rather than carbon monoxide poisoning.

Wood gas users and automobile mechanics were advised to never work alone and to keep a close watch on co-workers' state of health. ${ }^{43}$ As most automotive transportation and repair during World War II took place within the professional transport sector, carbon monoxide poisoning was mainly discussed as a work place hazard. ${ }^{4}$ Particularly dangerous aspects were gasifier ventilation and the gas accumulation after the engine was shut off. Gas could also leak into vehicles during driving - a consequence of poor welding and faulty packings. The cold winter season proved particularly problematic as employers and workers were less inclined to air out their premises with cold outdoor air. According to the Gengasnämnden

40 | Ingenjörsvetenskapsakademien: Gengas, 328-331; Gengasnämnden, vol. Ellbc:2. Statens bränslekommissionen (1940). RA; Gengasnämnden, vol. Ellc:1. Statens bränslekommission (1940), RA.

41 | Ingenjörsvetenskapsakademien: Gengas, 331, 333, 341; Motormännen: Motormännens gengasbok, 71-73.

42 | Ingenjörsvetenskapsakademien: Gengas, 316-317; Gengas. Stockholm: Sveriges läkarförbunds förlagsaktiebolag, 1943, 7.

43 | Ingenjörsvetenskapsakademien: Gengas, 318; Motormännen: Motormännens gengasbok, 78 .

44 | See for example Governmental bill 1945:215, 7. 
employed engineer Nils Gustafsson, faulty gasifiers and the users' negligence of safety instructions were equally common causes of carbon monoxide poisonings. ${ }^{45}$ According to carbon monoxide specialist medical doctor Ernst B. Salén, traffic accidents increased as a direct result of the obscured judgement of drivers in the early onset of acute carbon monoxide poisoning. ${ }^{46}$

Awareness of the poisoning risk linked to wood gas became widespread, resulting in several brochures on wood gas safety and chapters in wood gas maintenance instruction books and leaflets. ${ }^{47}$ Labour unions and state authorities responded to the poisoning risk by decreeing that warning signs should be hung up in all work places where wood gas was used. Carbon monoxide indicators and information campaigns became relatively effective tools for decreasing the percentage of carbon monoxide poisonings with a lethal outcome from 11.7 percent in 1940 to less than one percent in $194^{2 .} .^{8}$

Acute carbon monoxide poisoning was the first known poisoning hazard of wood gas. Gradually, however, attention was also directed towards chronic carbon monoxide poisoning (during the war more commonly referred to as chronic wood gas poisoning). Because of the correlation to wood gas usage it was defined as an occupational disease during the war years. The hypothesis behind the diagnosis was that constant exposure to small doses of carbon monoxide over a prolonged period of time caused a state of lethargy. The most common symptoms included fatigue, headache, vertigo, broken sleep, apathy, change in temperament and cardiac symptoms. Due to the diffuse nature of the condition and the difficulties in proving a somatic origin to the condition, the diagnosis became the subject of a post-war medical-scientific controversy. 49 Regardless of the

45 | Gengas. Stockholm: Sveriges läkarförbunds förlagsaktiebolag, 1943, 19-25.

46 | Ingenjörsvetenskapsakademien: Gengas, 332.

47 | Tore Leonhart: “Kontroversiell förgiftningsepidemi lade grund för yrkesmedicinen”, in: Läkartidningen 102:14 (2005), 1062.

48 | Ingenjörsvetenskapsakademien: Gengas, 318; Motormännen: Motormännens gengasbok, 325-26, 333-43.

49 | Helena Ekerholm: "Gengas och ohälsa. Den medicinsk-vetenskapliga kontroversen kring kronisk koloxidförgiftning 1944-1961”, in: Lychnos. Uppsala: Lärdomshistoriska samfundet, 2010. 
scientific controversy surrounding it, chronic carbon monoxide poisoning was often pinpointed as a serious risk of wood gas usage. From 1943 to 1944, the officially recognised cases of chronic carbon monoxide poisoning increased from circa 300 to circa 1,600..$^{\circ}$ For labour unions and Sveriges kommunistiska parti (the Swedish communist party represented in Parliament) combatting chronic carbon monoxide poisoning became a work place safety issue. Necessary measures could not wait for medical science to resolve the controversy..$^{51}$ Wood gas usage, with its negative health effects, thus became a political issue for left-wing organisations and labour unions.

\section{Troublesome Maintenance}

As the wood gas commission had stated in the interwar years, the preconditions for successful wood gas use were substantial user interest in and knowledge of the socio-technical characteristics of wood gas. However, not all drivers or repair shop personnel could summon up sufficient enthusiasm. Employers who had the good fortune of finding employees with the necessary skills for dealing with wood gas ran the risk of losing their wood gas specialist to the conscription army. ${ }^{2}$ The specific wood gas driving technique demanded special attention from the driver. ${ }^{53}$ Apart from the extra workload of emptying the gasifier and then, carefully and with precision, refilling and lighting it again, which in itself was a process that could take up to 15 minutes, driving a wood gas propelled vehicle required a different driving technique from that used by petrol-driven vehicles. The driver had to keep a constant eye on the air-gas mixture proportion in order to avoid engine stops. Engine rpm needed to be kept

50 | Preliminary report from Sabbatsbergs sjukhus, 21.09.1945, in: Drivmedelsutredningen 1944, vol 1, RA; Sveriges officiella statistik/ Riksförsäkringsanstalten: Socialstatistik. Olycksfall $i$ arbete. 1938-1951, tables 11a-b.

51 | Governmental bill 1945:215; Parliamentary bill 1945:348, second chamber; Statsutskottet (Budget Committee), formal report 1945:68, 6-7.

52 | Letters from Aktiebolaget Lovén \& Co 07.05.1940 and Motorkompaniet Linder \& Forsberg 26.04.1940, in: Gengasnämnden, vol Ela:4. Statens bränslekommission (1940), RA.

53 | Motormännens Riksförbund: Motormännens gengasbok, 63. 
at a constant level, which entailed energetic gear shifting. Stops needed to be kept to a minimum, both in occurrence and length of time. After three hours the gasifier had to be completely restarted. ${ }^{54}$ Also, due to a relatively low thermal value, wood gas propelled vehicles were slower, had poorer acceleration and hill climbing capacity than petrol and ethanolfuelled automobiles. Wood gas specific waste such as odour, grime and cinders, forced authorities to decree premises for starting, cleaning and maintenance of wood gasifiers. 55 Wood gas maintenance was described as specifically unfit for women and minors, due to the difficulties of adapting to wood gas user practice. But imagery of women engaged in wood gas maintenance was sometimes used to illustrate the simplicity of wood gas use in gasifier manufacturers' marketing strategies and cheerful articles in popular press. ${ }^{5}$ If women could use wood gas, then anyone could.

Although it could be used in a large number of application fields, wood gas did not have the multifunctional, easy-usage qualities of liquidfuelled internal combustion engine automobiles. In this capacity, wood gas vehicles could be likened to electric and steam vehicles, which also had socio-technical characteristics seen as being disadvantageous within automobile culture: slowness, starting procedures with higher demands

54 | Motormännen: Motormännens gengasbok, 31-32, 53-59; Carl Skånberg: Gengasboken. Stockholm: Saxon \& Lindströms förlag, 1940, 51-53.

55 | "Våldsam reaktion mot gengaslukten tvingar myndigheterna till handling. Generalplan för 70 'gengaskarantäner' framlägges i Stockholm. Chaufför som slaggade på gatan fick två tänder utslagna", in: Nya dagligt allehanda 09.01.1941; "Att slagga på kvällen - medel mot gengasos. Illaluktande nytändning på gatan ofrånkomlig, men det rör sig...", in: Svenska Dagbladet, 12.01.1941. Both articles from volume 5:45 at Tekniska museets motorhistoriska samling, (Archive, Tekniska museet) Stockholm. See also advertising for the gasifiers Vedi and Koli, which were advertised as clean, easy-use gasifiers that would "spare your suit” and make driving a “"pure' pleasure”, in: vol. L7, Tekniska museets motorhistoriska samling, (Archive, Tekniska museet) Stockholm.

56 | See letter from Lovén \& Co, 07.05.1940, in: Gengasnämnden, vol Ela:4. Statens bränslekommission (1940), RA; Communication to Folkhushållningsdepartementet from R. Bennet, 17.04.1940, 9, in: Gengasnämnden Ela:6. Statens bränslekommission (1940), RA. See also photo of women in wood gas related occupation in: Biljournalen 2, 1940, 16. 
for user effort and a symbolic label of old-fashionedness. ${ }^{57}$ Like wood gas vehicles, the steam automobile was considered dirty and dangerous. Fear was a common negative association with the steam engine ${ }^{5}$, and was also one of the most defining perceptions of wood gas. But a comparison also shows considerable differences between these three automobile types. The sources suggest that wood gas usage was seen primarily as an occupational activity entrenched in masculine working-class symbolism, whereas the use of an electric vehicle encompassed feminine higher strata coding. 59 The defining qualities of the wood gas, electric and steam automobiles were not in line with user practice ideals: trouble-free operation, long uninterrupted driving distances, high speed and multi-functionality.

\section{Petrol Returns}

As the prospect of peace appeared on the horizon, there was evidence in the popular press of growing hopes for a future without wood gas. The assessments of wood gas were, however, ambiguous. On the one hand, it had enabled vehicle transportation for private and enterprise consumers alike during a time of great hardship. On the other hand it was inconvenient. ${ }^{60}$

57 | Mikael Hård/Andrew Jamison: "Alternative Cars: The Contrasting Stories of Steam and Diesel Automotive Engines", in: Technology in Society 19:2 (1997), 148-49.

58 | Clay McShane: Down the Asphalt Path. The Automobile and the American City. New York: Columbia University Press, 1994, 97.

59 | About the properties of the electric vehicle see Gijs Mom: The Electric Vehicle. Technology and Expectations in the Automobile Age. Baltimore, MD: The Johns Hopkins University Press, 2004, 128, 150, 278-81.

60 | "Moren kan gå”, in: Dagens Nyheter, 03.11.1944; “Bränslet skapar nästan panik i bussbolag och verkstäder”, in: Stockholms-tidningen, 18.10.1945. Both from volume 5:45 at Tekniska museets motorhistoriska samling, (Archive, Tekniska museet) Stockholm. See also: "Moren har gjort sin plikt, moren går, säger gengasman”, in: Dagens nyheter, 02.11.1944; “Gengasen högst impopulär bland vår orts trafikbilägare”, in: Lidköpings-tidningen, 25.10.1944; “Fortsätter Ni med gengasen efter kriget? 100 svara NEJ - d.v.s. under förutsättning att bensinen inte blir alltför dyr", in: Aftonbladet, 23.07.1944; "Försvinner gengasen med kriget? Motormännen spå återgång till bensindrift”, Mellersta Skåne, 
In competition with other 'strong' and 'powerful' fuels it was expected to become a fuel to look back on, rather than having hopeful visions of. News articles on the topic of automobile fuel mainly focused on the less attractive characteristics of wood gas usage: messy maintenance, low effect and hazard. There is also an interesting comparison to ethanol which was the other main fuel alternative in Sweden during the war years. Although petrol and ethanol have been in on-and-off contestation for decades, they are quite similar when compared with other fuel alternatives. Apart from adjusting the engine for one or the other, user practice required few, if any, adjustments. Automobile design aimed at constructing engines of higher speeds, with ever increasing rpm and more horsepower, as these have been desired socio-technical characteristics of an automobile, symbolising the independence of the modern life-style. ${ }^{61}$ Speed, covered distance and maintenance procedures were technical characteristics similar enough to make petrol and ethanol symbolic equals. Whereas a bus propelled with liquid fuels was 'real', a wood gas fuelled bus was something else, even if it performed essentially the same task, namely the transport of people from point A to point B. Automobility entailed freedom of mobility with high speed and power and a minimum of operational hassles. The passenger car served as a symbol of modernity and development. ${ }^{62}$ None of these attributes were credited to wood gas usage. For the contemporary

12.08.1944. Examples of articles which address the usefulness of wood gas during war time, in spite of substantial user problems: “'Giftburkens' saga ej slut i och med det att kriget upphör”, in: Aftonbladet, 06.11.1944; “Gengasen får stor uppgift även i fred, anser Svedlund”, in: Örebro-kuriren, 04.11.1944. All from Drivmedelsutredningen 1944, vol. 1, RA.

61 I Tom McCarthy: Auto Mania. Cars, Consumers and the Environment. New Haven, CT: Yale University Press, 2007, 28, 253, 262; Wolfgang Sachs: For Love of the Automobile. Looking Back into the History of Our Desires. Berkeley: University of California Press, 1992, 91-124.

62 | Georgine Clarsen: Eat My Dust. Early Women Motorists. Baltimore, MD: The Johns Hopkins University Press, 2008, 158; Olle Hagman: Bilen, naturen och det moderna: om natursynens omvandlingar $i$ det svenska bilsamhället. Göteborg: Socialantropologiska institutionen, 1999, 69-72; Sachs: For Love of the Automobile, 8-9; Virginia Scharff: Taking the Wheel. Women and the Coming of the Motor Age. New York: Free Press, 1991. Reprint, Albuquerque: University of New Mexico Press 1992, 165-66. 
observer, the use of wood gas did not correlate to the ideals of modernity. Instead, the characteristics of wood gas usage can be likened to those of the horse and carriage at the beginning of the $20^{\text {th }}$ century: powerlessness, slowness, tangible dirt, danger and frailty. ${ }^{63}$ General Manager of Svenska gengasaktiebolaget, Gunnar Magnusson, concluded that the Swedes' inherent dislike of the relatively troublesome and dirty gasifier maintenance was likely to cause a general return to petrol. ${ }^{64}$ Similar sentiments were aired at a confidential meeting held in November 1944, at which civil servants responsible for fuel issues and representatives for the automobile industry discussed the future of wood gas. The meeting was arranged by the Swedish government to foresee the future of automobile fuels during peacetime. Although representatives for the gasifier production industry were hopeful, or at least gave that impression, others concluded that without incentives such as tax exemptions, most wood gas users would dismantle their gasifiers at the first possible opportunity. The army, some state authorities and farms were mentioned as possible wood gas using sectors in the future, although the participants at the meeting had varying opinions on the usability of wood gas even for these users. ${ }^{65}$

In 1948, Gengasaktiebolaget was dissolved. Although wood gas usage was still of value for military purposes, in the civilian sector it was not continued as petrol import was resumed. The loan fund which had not been used since World War II, was discontinued in 1961 as the social democratic Minister for Agriculture thought it unnecessary to retain the loan funds merely for the sake of military preparedness. ${ }^{66}$

63 | For the horse carriage see Sachs: For Love of the Automobile, 1992, 5-9.

64 | "Moren har gjort sin plikt, Moren går, säger gengasman”, in: Dagens nyheter, 02.11.1944; KAK, gengasenkät, appendix 5, 3, 18, in: Drivmedelsutredningen 1944, vol 2, RA.

65 | Meeting protocol 02.11.1944, in: Drivmedelsutredningen 1944, vol. 3, RA. For information about the meeting participants affiliation, see short meeting protocol summary, 7, in: Drivmedelsutredningen 1944, vol. 1, RA.

66 | Budget bill 1961:1, appendix 31:6; Parliamentary communication 1961:6. 


\section{Concluding Discussion}

At the outbreak of World War II, the replacement of petrol with wood gas was no longer a policy vision but a necessity. As wood gas usage became more common, so did voices airing discontent with the drawbacks of wood gas. Influential trade unions representing professional wood gas workers cooperated with equally influential figures in the medical profession to pursue the debate on workplace safety. Wood gas became symbolically labelled as being hazardous. Although the negative health effects of wood gas were probably the main concern, the other characteristics did little to award it even a rhetorical civilian market niche in peacetime. Users were not ready to make the necessary adjustments to the socio-technical traits of wood gas. Furthermore, one of the most important political arguments for promoting wood gas in the interwar years had been to widen the market for forestry products. Rebuilding Europe after World War II, however, meant increased sales for Swedish forestry. There were no longer an economic crisis and production surplus motivating state initiatives for wood gas promotion.

Although the use of wood gas was in line with the idea of basing Sweden's wealth on the forestry industry, wood gas breached the standards set by ideologies more influential in daily life, namely automotive culture and progress-oriented ideals. Wood gas for automotive propulsion was a chronologically younger invention, but petrol (and to some extent ethanol) propulsion had the status of symbolic modernity for interwar and World War II automobile users. The symbolic connotations of surrogate and war gave wood gas a dating, a kind of 'best-before' label, which strengthened the symbolic division between wood gas as outmoded and low-tech, and liquid fuels as innately modern.

Viewed from an environmental perspective, the contemporary definition of dirt put wood gas at a disadvantage. The sooty refuse and odorous exhausts from wood gas were highly tangible; petrol emissions were discreet to the eye, hands and nose. To sum up, if wood gas propulsion meant reversing progress and moving back in time, the use of liquid fuels, especially petrol, was the self-evident choice for the future. 


\section{References}

\section{Unpublished Primary Sources}

Riksarkivet (The National Archives), Stockholm, Sweden

Drivmedelsutredningen 1944, volumes 1 and 3.

Gasgeneratorkommittén 1937.

Gengasnämnden, volumes A1; A2; EIa:4; EIIbc:2; EIIc:1. Statens bränslekommission (1940).

Jordbruksdepartementet, konselj 56, 12.03 .1938 (The Ministry for Agriculture, Cabinet meeting file No. 56, 12.03.1938).

Jordbruksdepartementet, konselj 58, 29.09.1939 (The Ministry for Agriculture, Cabinet meeting file No. 58, 29.09.1939).

Tekniska museets motorhistoriska samling (Archive, Tekniska museet), Stockholm, Sweden

Volume L7.

Volume 5:45.

\section{Official Records}

Riksdagens protokoll med bihang (Parliament protocols with appendage) 1930-1961.

SOU 1933:2. Stockholm: Jordbruksdepartementet, 1933.

Sveriges officiella statistik/ Riksförsäkringsanstalten: Socialstatistik. Olycksfall $i$ arbete. 1938-1951.

Statistiska centralbyrån: Statistisk årsbok för Sverige. Stockholm 1924-1940.

\section{Published Primary Sources}

Biljournalen, No. 2, 1940.

Bränsletekniska kommittén vid Ingenjörsvetenskapsakademien. Gengasdagen 8 juni 1943: Meddelande och diskussionsinlägg, Meddelande $n r$ 15, 1943.

Enström, Axel F. "Motorproblemet inom automobilindustrien”, in: Teknisk tidskrift: Automobil- och motorteknik, 16.04.1938, 25-26.

Gengas. Stockholm: Sveriges läkarförbunds förlagsaktiebolag, 1943.

Gierow, Pär. "Svenska erfarenheter av elbilen”, in: Teknisk tidskrift: Automobil-och motorteknik, 18.05.1946, 485-93. 
Ingenjörsvetenskapsakademien. Gengas. Svenska erfarenheter från åren 1939-1945. Stockholm: Generalstabens litografiska anstalts förlag, 1950. Motormännens Riksförbund. Motormännens gengasbok. Stockholm 1940. Reprint, Stockholm, 1941.

Skånberg, Carl. Gengasboken. Stockholm: Saxon \& Lindströms förlag, 1940.

\section{Secondary Sources}

Appadurai, Arjun. "Introduction: Commodities and the Politics of Value”, in: Arjun Appadurai, ed. The Social Life of Things. Commodities in Cultural Perspective. Cambridge: Cambridge University Press, 1986, 3-63.

Clarsen, Georgine. Eat My Dust. Early Women Motorists. Baltimore, MD: The Johns Hopkins University Press, 2008.

Douglas, Mary/Isherwood, Baron. The World of Goods. Towards an Anthropology of Consumption. New York: Basic Books, 1979. Reprint, London \& New York: Routledge, 1996.

Ekerholm, Helena. "Gengas och ohälsa. Den medicinsk-vetenskapliga kontroversen kring kronisk koloxidförgiftning 1944-1961", in: Lychnos. Uppsala: Lärdomshistoriska samfundet, 2010, 61-85.

Hagman, Olle. Bilen, naturen och det moderna: om natursynens omvandlingar $i$ det svenska bilsamhället. Göteborg: Socialantropologiska institutionen, 1999 .

Hård, Mikael/Jamison, Andrew. "Alternative Cars: The Contrasting Stories of Steam and Diesel Automotive Engines”, in: Technology in Society 19:2 (1997), 145-6o.

Jonter, Thomas. Socialiseringen som kom av sig. Sverige, oljan och USA:s planer på en ny ekonomisk världsordning 1945-1949. Stockholm: Carlssons, 1995 .

Leonhart, Tore. "Kontroversiell förgiftningsepidemi lade grund för yrkesmedicinen", in: Läkartidningen 102:14 (2005), 1061-67.

McCarthy, Tom. Auto Mania. Cars, Consumers and the Environment. New Haven, CT: Yale University Press, 2007.

McShane, Clay. Down the Asphalt Path. The Automobile and the American City. New York: Columbia University Press, 1994.

Mom, Gijs. The Electric Vehicle. Technology and Expectations in the Automobile Age. Baltimore, MD: The Johns Hopkins University Press, 2004. 
Mårald, Erland. "Methanol as Future Fuel: Efforts to Develop Alternative Fuels in Sweden after the Oil Crisis", in: History and Technology 26:4 (2010), 335-57.

Sachs, Wolfgang. For Love of the Automobile. Looking Back into the History of Our Desires. Berkeley: University of California Press, 1992.

Scharff, Virginia. Taking the Wheel. Women and the Coming of the Motor Age. New York: Free Press, 1991. Reprint, Albuquerque: University of New Mexico Press, 1992.

Sundin, Bosse. "Från avfall till möjligheter. Etanol i början av 1900-talet”, in: Polhem. Uppsala: Svenska nationalkommittén för teknikhistoria, $2005,65-84$. 



\title{
Missing Green in the Black Gold
}

\author{
Environment in the Public Debate on West Siberian Oil \\ Production from the 1970s to the Present
}

VAlentina Roxo

West Siberia's substantial oil reserves have played a central role in Russia's geopolitical and economic rebirth. West Siberia is Russia's most highly developed oil province, producing 78 percent of all Russian oil. The process of development, which started in the late 1960 s, has been characterized by a minimal regard for environmental protection, preservation of cultural properties, or effective consultation with indigenous peoples. Over the last 50 years from a poor, sparsely populated area (around 120,000 in 1960) there emerged a highly industrialized region with a population of 15 million and the highest gross regional product.

The choice of West Siberia as the regional focus of my study has to do with the uniqueness of this area, which despite its remoteness, mirrors the entirety of Russia in several respects: Geographically, its territory stretches from the northern to the southern state borders, including almost all of Russia's climate zones. From a historical perspective, the region has experienced all major stages of development, typical for most Russian territory: conquest by the expanding Russian state, establishment of military and later total political control, agricultural cultivation, development of the processing industry along with the construction of the Trans-Siberian Railway, and forced industrialization. Ethnically, the region's population includes all three groups represented in the Russian population - Slavic, Turkic, and Finno-Ugric. In terms of politics and administration, the region has a federal structure with the problems of separation of powers and clashes between the centre and the regions - problems typical of 
Russian federalism. But most importantly, it is the development of the oil industry in West Siberia that has had a deep impact on the late Soviet and post-Soviet history of the region and of the entire country.

Russian historiography, however, clearly lacks works on the late and post-Soviet environmental history. ${ }^{1}$ Material histories concerned with the late Soviet Union and the newly created Russian Federation are just beginning to accumulate. This project attempts to fill this gap as it constructs an environmental history of the region by studying the meanings which the society attributed to the natural resource oil. ${ }^{2}$ By focusing on West Siberia, this study offers a perspective on the provinces, a much neglected area in terms of research. Existing historical works on Russian oil production either analyze political decisions regulating oil exploration ${ }^{3}$, or praise the heroism of the first geologists and oilmen. ${ }^{4}$ With the exception of anthropological ${ }^{5}$ and ethnological ${ }^{6}$ studies related to West Siberian indigenous population, humanities research on Soviet and postSoviet oil production omits the issue of environmental impact. Given both

1 | More on Russian environmental historiography in Andy Bruno: "Russian Environmental History: Directions and Potentials”, in: Kritika: Explorations in Russian and Eurasian History 8:3 (2007), 635-50.

2 | More on the subject of environmental history in Donald Worster, ed.: The Ends of the Earth. Perspectives on Modern Environmental History. Cambridge: Cambridge University Press, 1988, 289-308.

3 | Maria Slavkina: “Istoria Prinyatiya Reshenia o Promyshlennom Osvoenii Zapadnoi Sibiri" (History of Decision Making on Industrial Development of West Siberia), in: Economicheskaya Istoria 10 (2005), 146-62. Hereinafter, all Russian quotations and titles were translated by the author.

4 | See e.g. Matvey Krol, ed.: Neftianaya Epopeya Zapadnoy Sibiri (The Oil Epic of Western Siberia). Moskva: Parnas, 1995 or Sergey Kazantsev, ed.: Energia Ugry: Istoki (Energy of Yugra: the Roots). Vol. 4: Vsem Mirom (All Together). Yekaterinburg: Parkus, 2002.

5 | Marjorie Mandelstam Balzer: "The Tension between Might and Rights: Siberians and Energy Developers in Post-Socialist Binds”, in: Europe-Asia Studies 58:4 (2006), 567-88.

6 | Anna Sirina: “Oil and Gas Development in Russia and Northern Indigenous Peoples", in: Elana Wilson Rowe, ed. Russia and the North. Ottawa: University of Ottawa Press, 2009, 187-203. 
its insufficiency and policy importance, historians could contribute to the development of an environmentally conscious public discourse on oil.

This paper aims to trace the change of oil meanings over the last four decades in order to evaluate the public awareness about the environmental damage caused by West Siberian oil production, and the state's disposition to conduct a responsible energy policy. This analysis will help understand the historical background of contemporary Russian energy mentality. To fulfill this task, this work examines a bulk of oil discourse sources consisting of a variety of newspaper accounts, and articles in historical and sociopolitical journals related to West Siberian oil industry over the investigated period. This paper employs the notion of 'discourse' as an aggregate of utterances, speech acts and practices related to a certain issue and positioning this issue within the public sphere.

The meanings attributed to oil are analyzed against the backdrop of their respective political and economic contexts. What images of oil did the state impose on the society and what meanings of oil did the society in turn construct? How did people perceive the change which oil development had caused to the environment? The study pays special attention to the emergence of such themes as environmental awareness and resource finiteness in the oil discourse. When and why did the analyzed discursive themes appear? Did they signify a transition to a more environmentally sensitive society?

The investigated Soviet media dating from before 1986, as well as historical and sociopolitical journals, were heavily propagandistic and praised the progressive role of oil. Only in the late 1980 did scholarly journals begin to publish articles that described the catastrophic environmental condition of the largest oil province. But such writings have remained rare until now and are dominated by articles on the danger that oil dependence poses to the national economy. The first comprehensive works on the damage that West Siberian oil production caused to the environment, the indigenous population and the national economy appeared in the early 1990s and were published abroad. Other valuable sources for this study are transcripts of meetings of Soviet Council of Ministers behind closed doors, found in the state archive. Further primary sources, analyzed in order to put the investigated patterns of the oil debate into appropriate historical context, are governmental acts and statistics.

My research rests on the hypothesis that the collapse of the totalitarian regime in the 1990 caused a discursive shift, but that the change of oil 
perceptions to more critical ones did not mean that either the state or the society became more sensitive to environmental damage inflicted by oil production.

Russian environmentalists argue that in the past three decades Russia has seen several changes in attitudes towards environmental protection on behalf of both society and state: The state ecology experienced a rapid upsurge in the late 1980 s and a brisk rollback during Putin's presidency. ${ }^{7}$ However, this study argues that the indicated rise of environmentalism did not have any effect either on Soviet oil production in general or on the perception of the oil-related ecological problems.

The time frame of my study begins in the 1970s as it is the starting point of 'big West Siberian oil' and simultaneously the years that brought the world oil shock and first Soviet environmental legislation. The period under investigation stretches over the peak oil of the mid-1980s, the rise of environmental movements in the USSR in the late 1980s, the collapse of the Soviet Union to the transformation years until the present day. The analyzed period allows the examination of not only the beginnings of a high industry region, but also the economic and political concerns which led to a change in the implications of oil.

\section{0s: Big Oil and Cold War Geopolitics}

In 1970, West Siberia was already considered a large oil region by international standards. During the following twelve years, oil production there increased twelvefold. The Soviet government discussed intensively how to exploit the West Siberian deposits most effectively. The oil industry experts warned $\mathrm{CPSU}^{8}$ leadership and Gosplan ${ }^{9}$ that it would be impossible to increase the production at such a rapid pace in the future without facing serious technical problems. The 1965-1977 oil minister Shashin often engaged in heavy discussions with the Gosplan decision-makers, arguing that the planned extraction rates went against geological norms and that such

7 | See e.g. Vladislav Larin/Mnatsakanyan Ruben/Igor Chestin/Evgeniy Shwarts: Okhrana Prirody Rossii: ot Gorbacheva do Putin (Russia's Nature Protection: from Gorbachev to Putin). Moskva: KMK, 2003.

$\mathbf{8}$ | The Communist Party of the Soviet Union.

9| The State Planning Committee. 
policy was short-sighted. Thus, he would criticize a Gosplan representative: "You are a risk taker! Where are you taking the country with your policy, do you think about the consequences of such a production increase?"10 Yet, the party told the oil ministry there was no other choice. The Soviet premier, Aleksey Kosygin, used to call the chief of the Tyumenneftegaz (the oil and gas mining division at the time), Viktor Muravlenko, and explain the desperation of the situation: "Please give three million tons on top of the plan. The situation with bread is awful." source of Soviet hard currency earnings between 1973 and 1985. This is what Gorbachev's colleague, the Chairman of the Council of Ministers Nikolai Ryzhkov, explains in his book: "We export raw materials because nobody wants to buy anything else from us for free convertible currency." ${ }^{12}$ By the 1970s, when not enough such raw materials were available for exports, the state was on the verge of bankruptcy. Starting in 1964, the Soviet government had to increase its grain imports annually. ${ }^{13}$ Without the discovery of Siberian oil, the Soviet Union might have collapsed decades earlier simply because it would not have had enough hard currency to pay for its wheat imports. The only reason why the Soviet Union did not cease to exist after it had become the world's largest grain importer, was the discovery of West Siberian oil fields. Luckily, the new deposits were truly unique due to the shallow bedding and high flow rate. Besides, the oil was relatively light, with low content of sulfur and paraffin. In particular, oil originating from the Latitudinal Ob region has been even qualitatively better than the Brent Crude - the oil blend used as a benchmark to price two thirds of the world's internationally traded oil supplies. ${ }^{14}$ Thus, the ninth and tenth five-year

10 | Qtd. in Egor Gaydar: Gibel' Imperii. Uroki dlia Sovremennoi Rossii (The Collapse of an Empire: Lessons for Modern Russia). Moskva: Rosspen, 2006, 48.

11 Q Qtd. in Maria Slavkina: Triumf i tragedia: razvitie neftegazovofo kompleksa SSSR v 1960-1980-e godi (Triumph and Tragedy: Development of the Oil and Gas Complex in the USSR 1960s-1980s). Moskva: Nauka, 2002, 143.

12 | Nikolai I. Ryzhkov: Desyat let velikikh potryaseniy (Ten Years of Great Distress). Moskva: Assotsiatsiya “Kniga, Prosvyashenie, Miloserdie”, 1995, 229.

13 | Vneshniya Torgovlya SSSR (Foreign Trade of the USSR), 1966-1978. Ministry of Foreign Trade, Moskva: Statistica.

14 | Oil characteristics are taken from Vagit Alekperov: "Zapadno-Sibirskoye 'Chernoye Zoloto'” (West Siberian 'Black Gold'), in: Neftyanik Zapadnoy Sibiri, 31.10.2009, 2. 
plans for 1971-1975 and 1976-1980, respectively, scheduled the doubling of oil extraction. The realization of this strategy relied largely on the newly discovered oil fields in the Tyumen oblast. ${ }^{15}$

The 1973 oil shock made the Soviet government rely even more on the profits from selling Tyumen oil to pay for imported grain, equipment, and most importantly to keep military spending at its traditionally high level. The resulting excessive oil pumping did not correspond with the geological and environmental norms, leading to premature field depreciation and to long-term ecological problems. But in the 1970 s environmental issues were still far from entering the discourse on oil development. At that point, the government was mainly concerned about the sufficiency of oil export revenues to keep the stagnating economy afloat. The task of the Soviet press, however, was to persuade the people of the richness of their motherland that was supposed to be rapidly pacing toward the bright communist future. ${ }^{16}$ Newspapers were glorifying the abundance of the country's petroleum reserves: "The Soviet Union has plenty of oil and we generously share it with other countries of the socialist camp." ${ }^{17}$ Thus, the discovery of West Siberian oil created the notions of 'oil excesses' and 'oil beyond plan'. ${ }^{18}$ These notions, in turn, became convenient propaganda tools to create the myth of a prospering economy, serving as the locomotive of the entire Socialist bloc.

The geopolitical implication of the new deposits was praised in nearly every oil-related writing of the time: "Each year West Siberian oil and gas complex plays a greater international role, which strengthens the positions of the USSR on the world arena, as well as of the other socialist countries, and gives them new opportunities to compete economically with the West $[\ldots]$ and Siberian oil thus serves the development of international cooperation

15 | Tyumen Oblast (district) is the largest administrative unit in West Siberia.

16 According to The Third Program of the CPSU, adopted by the $22^{\text {nd }}$ Congress of the CPSU in 1962, the Soviet society would have built communism by 1980 , which, among others, meant that "[...] all the springs of cooperative wealth will flow more abundantly and the great principle "From each according to his abilities, to each according to his needs' will be implemented.", Program of the Communist Party of the Soviet Union. New York: International Publishers, 1963, 71.

17 | "Kuda potechyot neft?" (Where Will the Oil Flow? ), in: Pionerskaya Pravda, 13.12.1960, 1.

18 | Sergey Bogatko/Sergey Chursin: "Sopernichaya s solntsem” (Competing with the Sun), in: Pravda, 30.06.1971, 2. 
and forges peace in the whole world."19 But the structure of oil exports that was established by the beginning of the 1980 s was far from economically viable. In 1981, the USSR sold 90 million tons of crude oil to the Socialist 'brother-countries' (12\% of the oil extracted in 1981) at the average of 117-130 rubles per ton. ${ }^{20}$ In comparison, the price on the capitalist market, to which USSR exported around 65-70 million tons a year, was 250-270 USD per ton. ${ }^{21}$ Obviously the goal of this trade was to 'buy' the political obedience of the Socialist bloc. By the early 1980s, the Soviet government almost ran out of the resources that nourished this political cooperation.

\section{0s: Peak Oil and the Soviet Edition of 'Promethean' Discourse ${ }^{22}$}

In the 1970s, Soviet people sincerely believed in the imminent approach of communism, which the party had promised to achieve by 1980 . The

19 | Viktor Alekseyev: “Istoricheskiye ocherki. Otkritiye Sibirskoy nefti” (Historical Outlines. Discovering Siberian Oil), in: Voprosy Istorii 5 (1986), 79.

20 | Vneshniya Torgovlya SSSR v 1981 (Foreign Trade of the USSR in 1981), Ministry of Foreign Trade, Moskva: Statistica, 1982, 254.

21 | Vneshniya Torgovlya SSSR v 1981, 256.

22 | 'Promethean' or 'cornucopian' view of nature-human relationship emerged in the early 1980 s as a response to survivalism and was manifested first by Julian Simon in his work The Ultimate Resource (1981). Ecosystems impose no real constraints on human activity - in particular, on economic growth. In Greek mythology, Prometheus stole fire from Zeus and thereby empowered people to manipulate the world for their benefit. Prometheans perceive nature as brute matter that can be transformed into goods in order to keep the economy on a positive growth track. Any problems that might occur in the transformation, i.e. environmental problems, can and will be solved through technological innovation. These Promethean ideas match well with the Marxist-Leninist concept of natural resources and the relationship between humans and their environment, both discussed in this section. Drawing an analogy between the Soviet (and later Russian) discourse on natural resources and the Promethean discourse is helpful for the analysis of the oil-related abundance rhetoric. For further reading on the Promethean discourse see John S. Dryzek: The Politics of the Earth: Environmental Discourses. New York: Oxford University Press, 1997. 
environment, they believed, could not be endangered in the country so close to the most advanced form of society, which was comprised of flawless Soviet people. According to the leading ideologist of the official "new biology'23, the dean of the Faculty of Biology at Moscow State University, Isaac Present, the Soviet Union did not need environmental protection: "Who do you want to protect our nature from? From the Soviet people?" 24 Such ideology destroyed all elements of Soviet ecological science which had developed before 1948 .

Until the mid-1980s, environmental data was secret in the USSR. Only as the result of glasnost reforms, catalyzed by the Chernobyl disaster, the government released its measurements of contamination levels, estimations of doses of absorbed radiation, and health statistics. ${ }^{25}$ For the first time in Soviet history, it became possible not simply to conduct a full-scale ecological inspection but also to publish its results. This was the jump-start of the ecological movement in the country. The All-Russia Society for Nature Protection (the first Russian ENGO) gained political power and participated in law making. In 1988 the State Committee on Nature Protection was founded. First Western ecology textbooks were translated into Russian. ${ }^{26}$ Greenpeace and the World Wildlife Fund opened their offices in the USSR. The Sixth Congress of the Union of Writers

23 | The 'new biology' (currently referred to as 'Lysenkoism') was a pseudo-biological science, conform to Marxism-Leninism, developed in 1948 by a Ukrainian agronomist Trofim Lysenko, a political favorite of Stalin. Lysenkoism rejected the advancements of genetics and mandated that all biological research conducted in the USSR conform to a modified Lamarckian evolutionary theory. Its underlying appeal was that all organisms were not genetically constrained, which was consistent with the desire in the USSR to assert that heredity had a limited role in human development; that people living under socialism would lose any bourgeois or fascist instincts.

24 | Nikolai Vorontsov: "Dlia Nas i Potomkov. Okhrana Prirody do Lysenko, Berii, pri Nikh i Segodnia" (For Us and Our Descendants. Nature Protection before Lysenko, Beria, at Their Time and Today), in: Izvestia 228, 12.06.1989, 3.

25 | For further reading see e.g. Arthur T. Hopkins: Unchained Reactions: Chernobyl, Glasnost, and Nuclear Deterrence. Washington, DC: National Defense University Press, 1993.

26 | Eugene Odum: Ecology. 2 Vols., 1963, translated from English. Moskva: Mir, 1986. 
of the RSFSR (December 1985) turned into a tribune for protest against the project of Siberian river reversal. ${ }^{27}$ In 1987, a short novel Povorot ('The Turn') by Sergey Zalygin was published in the literary journal Novii mir. The author criticized the government's project of river rerouting as an act of tremendous violence towards nature. There was also an earlier example of literary criticism of official modernization projects, causing destructive transformation of landscape - Valentin Rasputin's 1979 novel Farewell to Matyora. However, no such literature was dedicated to gluttonous oil pumping.

The adaptation of the Decree on the Fundamental Reorganization of Nature Protection (1988) and the foundation of the State Committee for Nature Protection of the USSR (1988) were heralded by a debate, which referred to the catastrophic ecological situation around the West Siberian oil fields. Nevertheless, this issue, in contrast to the project of the river reversal, did not gain publicity. The only mention of oil in the new legislation on nature protection addressed the Ministry for Chemical and Petroleum Engineering, which was then obliged to work out guidelines for assuring that machine manufacturing was environmentally compliant. ${ }^{28}$

Despite the rise of glasnost, the critical situation in the oil sector seemed to be completely left out of the public debate. However, the developments in the oil production in the mid-1980s deserved public reaction. In 1983, for the first time, West Siberia did not fulfill its production target, being 3 million tons short of the plan and 5 million tons below the plan in $1984 .{ }^{29}$ The deteriorating national economy was losing its main source of revenue:

27 | In the 1980s, twelve of the Arctic Ocean-bound rivers were proposed to be redirected to the south, in order to supply water to the southern part of West Siberia and to Kazakhstan. The project was closed due to environmental risks it was posing, which were actively discussed by Soviet writers in the mass media and in the published literature.

28 | Postanovlenie CK KPSS, Sovmina SSSR ot 07.01.1988, N32 "0 Korennoy Perestroike Dela Okhrany Prirody v Strane" (Decree of the Central Committee of the CPSU and the Soviet of Ministers of the USSR from 17.01.1988, No. 32 "On the Fundamental Reorganization of Nature Protection in the Country"), paragraph 24. http://base.consultant.ru/cons/cgi/online. cgi?req=doc;base=ESU; $n=770$, Accessed: 06.09.2011.

29 | Matthew J. Sagers/Milford B. Green: “Transport Constraints in Soviet Petroleum”, in: Energy Policy 13:4 (1985), 376. 
But the government badly needed additional petrodollars in order to cover the budget deficit, worsened by the continuing war in Afghanistan. All existing economic plans, however, were based on the assumption that the oil production would steadily grow. From 1981 to 1986, the world oil prices decreased six-fold. This meant the collapse of the Soviet economy. The government was perfectly aware of the approaching decline, as is obvious from the minutes of a meeting at the prime-minister's office in 1989:

"Over the last 10-15 years we have increased capital investments fivefold, but there is still no growth in oil production. Since 1989 there has been a sharp decline. We import 15-18 percent of the equipment for the oil industry. In several years we will be at 30 percent. The structure of oil deposits is changing dramatically: the active deposits are becoming smaller, mining costs are rising. Export is declining. Next year we will be able to export only 60 million tons [...] and then we are going to bury everything [...] I see, if there's no oil there's no national economy." ${ }^{30}$

However, the public was not aware of such government discussions behind closed doors and was told the country needed more oil for its rapidly developing automotive and air transport. ${ }^{31}$ At his meeting with the Tyumen's oilmen, Gorbachev said they needed to extend mining in order to support the economic growth of the Soviet Union on its way to communism: "The party has put forward serious goals of increasing economic growth. And I'll be direct: for reaching them, the country has to have enough oil and gas resources at its disposal. And this primarily depends on the work of

30 | Transcript of the meeting at the office of the USSR Chairman of the Council of Ministers comrade Ryzhkov N.I. "0 postavke dlia gosudarstva nefti, gazovogo kondensata I nefteproduktov v 1990 godu" (On the state supplies of oil, gas condensate and oil products in 1990), 17.09.1989, State Archive of the Russian Federation, F. 5446, 0p. 162, D. 379, L.143.

31 | Postanovlenie XXVI S'ezda Kommunisticheskoy Partii Sovetskogo Soyuza po Proyektu CK KPSS “Osnovniye Napravleniya Economicheskogo I Sotsialnogo Razvitiya SSSR na 1981-1985 gody i na Period do 1990 goda" (Decree of the 26th Congress of the Communist Party of the Soviet Union on the Project of the Central Committee of the CPSU "The Main Directives for Economic and Social Development of the USSR for 1981-1985 as well as until 1990"), in: Pravda, 03.03.1981, 1. 
the oil- and gasmen in Tyumen. Tyumen district is the main source of hydrocarbon resources, like no other."32

Due to additional capital investments and extensive extraction, West Siberia again managed to drag the country away from unavoidable collapse, and brought another five million tons beyond the plan. ${ }^{33}$ Such headlines kept the public faith in the power of the state for a short time, during which it was de facto disintegrating and inefficient in its economic reforms. Despite the growing environmental consciousness of the 1980 , the oil discourse still lacked an ecological dimension. Not least because of the Chernobyl catastrophe of 1986 , as a result of which petroleum was seen as a more secure source of energy than nuclear power.

The firm belief of the state in its capacity to constantly manipulate complex natural systems in combination with the rejection of environmental implications of such manipulations allow the classification of the official Soviet oil discourse until the late 1980 os as a socialist edition of a 'Promethean' discourse. Notions of finiteness of natural resources as well as environmental limits were simply denied. For 'Prometheans', there are no natural resources, ecosystems and even no nature itself at the ontological level. ${ }^{34}$ Likewise the Soviet oil industry treated nature as a brute matter and a store of energy. 'Prometheans' believe that nothing should constrain human activity. The concept of ecosystem does not play any role in their discourse. Accordingly, neither the term 'carrying capacity' 35 has any useful meaning to them. Interestingly enough, only rare (and relatively recent) Russian works on oil production use this term and use it in English, as there is no established Russian equivalent for it. ${ }^{36}$ 'Prometheans' have

32 Michail S. Gorbachev: Izbrannie Rechi i Stat'i (Selected speeches and articles). Moskva: Politizdat, 1985, 237.

33 | "Sverkhplanovaya neft" (Oil beyond Plan), in: Trud, 05.11.1987.

34 | Dryzek: The Politics of the Earth, 49.

35 | 'Carrying capacity' of environment or an ecosystem is the threshold limit of use of that system without damaging the system. Every ecosystem has its resources that are used for economic development, for survival and for habitat creation. Environment and ecosystems have got the abilities to recover the loss of these resources by regenerating them over a period of time. Environments, whose carrying capacity is exceeded, generate risks.

36 | Eduard Kulpin/Oleg Yanitsky: "Resursy i Perspectivy Socialno-Ecologicheskoy Modernizatsii: Problemi Sibiri i Dalnego Vostoka" (Resources and Perspec- 
unlimited confidence in the ability of humans and their technologies to overcome any problems they would encounter. Similarly, Soviet and Russian leaders attributed the occasional resource shortages to technological imperfections, which could be easily corrected by scientists and engineers. Despite having reached the peak oil in the mid-1980s, the Soviet leadership still regarded oil depletion with skepticism: “'Limitation' of oil resources is a relative factor and can be overcome not only by prospecting activities, but also by technological improvements in oil extraction. Until recently, there was no particular urgency for elaborating such technology."37 In fact, it was not the lack of urgency, but simply the inability to increase oil production by means of technological improvements: The technological base of the Soviet oil industry was poor and obsolete, lagging far behind international standards. Thus, production growth could only be extensive. Devastating environmental effects of the extensive oil extraction had not at all been a matter of concern.

While the Soviet leaders recognized that natural resources were finite, they did not share the pessimism of many of their Western counterparts. To many Westerners, the energy crisis in 1973 was only the first symptom of a general natural resource shortage which would eventually engulf the world. ${ }^{3}$ While the USSR recognized the existence of short-term energy and raw material shortages, Moscow did not agree that they were caused by the depletion of natural resources. Instead, the shortages were attributed to the socioeconomic organization of Western capitalism. Many Soviet sources stressed that the Western fear of resource depletion was not based on fact. Soviet Foreign Minister Gromyko, referring to hypothetical energyresource depletion emphasized: "[M]ankind - and all the specialists seem to agree on this point - is not threatened by energy strangulation. Science

tives of the Socio-ecological Modernization: Problems of Siberia and the Far East), in: Rossia Reformiruyushayasya 7 (2008), 464.

37 | A. S. Astakhov/A. D. Khaitun/G. E. Subbotin: "Socio-economic Aspects of Oil and Gas Development in West Siberia", in: Annual Review of Energy 14 (1989), 124.

38 | Daniel S. Papp: “Marxism-Leninism and Natural Resources: The Soviet Outlook", in: Resource Policy 3:2 (1977), 138. 
has by no means had its final say in the development of new sources of energy."39

Other Soviet sources cited statistics to show that there was no shortterm danger of either energy or resource depletion. Sotsialisticheskaia Industriia informed its readers that, at the current rate of consumption, chemical fuels would last another 150 years and nuclear fuels substantially longer, and that much more productive energy sources would be mastered long before existing fuel resources are exhausted. $4^{\circ}$

But unlike the capitalist Prometheanism, the socialist paradigm of industrial cornucopia arising from the pages of Pravda and Sotsialisticheskaia Industriia promised that once the Soviet Union and its allies (generously fueled with West Siberian hydrocarbons) had won the socialist competition and defeated capitalism, communism would create a world of unlimited plenty for everyone. Surely, such promises were a necessary propaganda tool to justify the miserable working conditions and poor social infrastructure in the areas of petroleum production.

\section{Oil-Related Modernization: Transforming Remote Villages into Industrial Centers and 'Savages' into Communists}

West Siberia's industrial development had begun in the second half of the $20^{\text {th }}$ century and its first stages had been connected mainly with geological prospecting of oil. The oil industry transformed the city of Tyumen from 'the capital of villages' into a West Siberian metropolis. Until the early 1990 , the petroleum industry was portrayed as a driving force behind economic development and social modernization in the region. Passages like the one below were in almost every newspaper article referring to West Siberia, emphasizing the beauty of the new industrial landscape and diverting the public eye from miserable living conditions in the emerging oil cities:

39 | Vystuplenie Gromyko na VI Spetsialnoy Sessii Generalnoy Assamblei 00N (Gromyko's Speech at the VI Special Session of the UN General Assembly), in: Pravda, 12.04.1974, 4.

40 | Sotsialisticheskaia Industriia, 28.11.1974, 1. 
"The music of oil fountains woke the Tyumen North up [...] The music of motors is accompanied by the never ceasing rumble of helicopters [...] Flying in the Siberian skies has now become merrier: instead of the dull green spots of swamps - clear lines of railways and roads, electric power lines, pipelines and concrete stripes [...] Towns, production fields and roads are born faster than maps are printed. Constantly developing new fields, the conquerors of the taiga are competing with the sun, reaching new deposits faster than the sun rays." ${ }^{11}$

Soviet propaganda praised the heroes taming the wild nature for the sake of producing more and more petroleum beyond plan to fuel the socialist construction. Monuments like the 1978 "Conquerors of Samotlor" 42 were erected. The giant male figure near the town of Nizhnevartovsk is still cordially referred to as "our Alesha" (gently called after the legendary folklore giant) and despite its explicit propagandist nature has turned into one of the main landmarks of today's Tyumen region.

Soviet media also eagerly glorified as progress that indigenous people of West Siberia had been integrated into the socialist system. "Under the influence of the Great October Socialist Revolution and with the help of the glorious Russian proletariat [...] the small peoples of the North, backward in their past, whose life was dominated by semi-savagery and even genuine savagery, now contribute significantly to the [...] construction of communism." 43 In the meantime, Khants, Mansi and Nenets - the West Siberian indigenous groups whose culture dates back to the ust-poluyskaya culture $^{44}$ - were becoming a minority on their lands and began losing

41 | Bogatko: “Sopernichaya s solntsem", 2.

42 | Samotlor is Russia's largest oil field, rating as the sixth in the world, discovered in 1965.

43 | Aleksey Novgorodov: "Istoricheskaia nauka v SSSR. Retsenzii. M. E. Budarin. Put' malykh narodov Krai'nego Severa k kommunizmu” (Historical Science in the USSR. Reviews. M.E. Budarin: The Road of the Small Peoples of the Far North to Communism), in: Voprosy Istorii 6 (June 1970), 134.

44 | Ust-poluyskaya is an archaeological culture of the Iron Age (6 $6^{\text {th }}$ century BC$2^{\text {nd }}$ century $A D$ ) found on the territory of the today's Yamalo-Nenets Autonomous Okrug (an entity in the Tyumen Oblast). For further details see Elena G. Fedorova: Rybolovy i ochotniki bassejna Obi: problemy formirovaniya kul'tury khantov i mansi (Fishermen and Hunters of the Ob Bassin: Problems of Formation of Khant and Mansi Culture). Sankt-Peterburg: Evropejskiy Dom, 2000, 6. 
resources to pursue their traditional semi-nomadic family-life based on hunting. Although a number of valuable ethnographic and archeological studies about these peoples had been published in the post-war years ${ }^{45}$, most of the mass media accounts on indigenous groups (including those published in the glasnost years) were highly conformist and praised the modernization evoked by the Soviet oil industry:

"Soviet people woke the tundra up, found oil and gas in its depths and [...] as V.I. Lenin mentioned, helped the small peoples of the North to pay the cultural debt of many centuries. From the Stone Age people here stepped into Socialism! Oh, healing pains of the world, Creator of the Earth - the Working Class!" 46

Such lines, although written by a Mansi author, do not show any regrets about the loss of traditional livelihoods due to construction infrastructure for oil-extraction. The native tribes had no choice but to conform to the Soviet ideology and get involved in the propaganda of the system, which was actually destroying their traditional way of life.

Glorification of the heroic oilmen on the one hand and of the progress to socialism of the indigenous people on the other clearly showed that in the minds of the Soviet elites, oil production was not just a process of acquiring an energy source. Its intention was also to ideologically conquer such remote and underdeveloped territories and set them on a socialist path.

Klaus Gestwa, who recently published a study about large-scale Stalinist projects, put forward the idea that erecting gigantic industrial complexes particularly in the energy sector was a form of technological colonization. ${ }^{47}$ This paradigm perfectly fits the development of the West Siberian oil industry in the 1970 s and 1980s. Transformation of virgin landscapes into highly industrial regions was linked to the hope that the society and its individual members could be similarly transformed. What Gestwa says about the transformation of the river landscapes in the post-war years

45 | Valentina I. Moshinskaya: Archeologicheskiye pamiatniki severa Zapadnoi Sibiri (The Artifacts of the North of West Siberia). Moskva: SAI, 1965.

46 | Yuvan Shestalov: "S vysoty rodnogo ochaga" (From the Height of My Native Hearth), in: Pravda, 20.11.1985, 3.

47 | Klaus Gestwa: Die Stalinschen Großbauten des Kommunismus. Sowjetische Technik- und Umweltgeschichte, 1948-1964. München: Oldenbourg, 2010. 
is a perfect illustration of the landscapes surrounding West Siberian oil fields: By producing energy, the gigantic constructions sites also produced illusions for the Soviet people. The large industrial construction projects also functioned as "stages of the Soviet modernity" 48 with the task of delighting the public. At the same time the 'construction giants' became sites of tragic confrontation and ecological disaster zones. But in the case of West Siberian oil industry the confrontation of interest groups and the recognition of the disastrous environmental impact arrived only after the demise of the system that had created this industry.

Ideologically, this technological colonization was largely based on the Marxist-Leninist tenet of continually expanding production which remained a major concern of the Soviet government. Accelerating economic growth was kept in high esteem in the socialist system, whereas Western scholars at that time began to advocate economic constancy and zero growth, in an effort to conserve scarce natural resources. The creation of the 'material and technical basis of communism' remained as important to Gorbachev in the late 1980 os as it had been to Brezhnev, Khrushchev and even Vladimir Lenin in 1918. The concept of zero growth to conserve natural resources was decried by Soviet authorities. Without the growth of productive capabilities, they argued, attainment of communism would be impossible. Thus, keeping up growing oil production - at least on the pages of printed media - was an essential tool of legitimization. The denial of oil's finiteness was certainly connected to these ideas and allowed Soviet politicians to present the future in a more optimistic light and thus justify the aspired conquest.

\section{Dispelling the Soviet Oil Myths}

The Soviet oil-related progress rhetoric was nothing but a propaganda tool. Only as late as after glasnost reforms, the true recognition of the destructive effect of the oil industry on the local population entered public debate. This time, the first critique came not from academic circles, but from oil workers themselves. An electrician from Nizhnevartovsk sent a letter to the historical journal Voprosy Istorii where alongside with unpaid salary, food and electricity shortages, he lamented gasoline deficit: "Here, where we

48 | Gestwa: Die Stalinschen Großbauten, 46. 
send hundreds of millions of tons of oil and gas to the entire country and abroad, there is not enough gas to fill up our cars!" Despite a commonly held assumption in many Western historical journals that oilmen had been the adversaries of indigenous people because of conflicts over land use and cultural rights, it was this electrician from a Nizhnevartovsk oil field who as one of the first posed a very daring question: "And who should be held responsible for the tragedy of Khanty, Mansi, Nenets and Selkupy? [...] Doctors are begging for help: Tuberculosis is taking over! [...] Contamination of the River $\mathrm{Ob}$ is 90 times higher than the permissible norms! [...] The Nizhnevartovsk district alone throws annually more than 300 thousand tons of petrochemicals in the river! Who is to be held responsible for that?!"49

A response from the academic world came in another analytical journal from Vladimir Sangi, a scholar of Nivkh origin. Sangi was among the first to pinpoint the value of the ethical principles, which regulated the relation of the indigenous peoples of the North to nature: "These principles appear to us as an [...] unreachable ideal from the future, [...] not the conquest and merciless exploitation, but the principle of consent and unity with nature." 50

According to the customary law of the indigenous peoples of West Siberia, one is not allowed to take any unnecessary excesses from the earth, but rather only resources needed for oneself and one's children. Khanty, Mansi and Nenets barely store up. Two very contradicting models of resource use: The sustaining approach of the indigenous population and the Soviet exploitive approach have been the essence of the conflicting situation in the oil province. The Khanty and Mansi families are de jure entitled to compensation from the oil-extracting companies operating on their tribal lands. De facto, such compensations have only rarely been paid and often not to the full extent..$^{1}$ However, based on the oversimplified but widely spread confrontation line 'oilmen - indigenous peoples of the

49 | Nikolai Nosonovich: Nizhnevartovsk Tyumenskoi oblasti. Pisma v redaktsiyu (Readers' Letters), in: Voprosy Istorii 10 (1989), 178.

50 | Vladimir Sangi/Anna Dmitrieva: “Spasti narodnosti severa, sokhranit' ikh kul'turu" (Save the Ethnic Groups of the North and Preserve Their Culture), in: Voprosy Literatury 3 (1989), 5.

51 | N. I. Novikova: “'Rodovyie ugodia’: Perspektivy Pravovogo Plzuralisma (Predstavlenia Predstavitelei Korennikh Narodov i Zakonodateley) ('Tribal 
North' in the media, the non-indigenous inhabitants of West Siberia envy Khanty and Mansi for their alleged privileges: “There are people in our country, who manage to get rent from the deposits, which belong to the whole nation, but are situated on their land. [...] To be able to work on these territories, oil companies have to pay the masters of the taiga in cash and in kind: with flour, butter, vodka and kitchenettes." 52

It was the researchers from the Institute of Geography of the USSR Academy of Sciences who among the first in the early 1990 s spoke about a broader spectrum of problems, namely "the conflict between the natural environment, the oil industry and the population." 53 Such works were soon followed by articles further dispelling oil's progressive role.

An important element of the new oil discourse was the oil city with its poor social infrastructure. The city was never on top of the socialist agenda. Oil revenues were largely reinvested in increased production and the search for new fields as well as other heavy industries. Thus, West Siberian cities constructed for the oilmen, whose work was sustaining the whole country, looked like "skinny teenagers, whose heart is just not capable of pumping enough blood for all the organs of the weak body, bizarre cities - wherever one touches them, it hurts." 54 Poor living conditions caused by factors such as lack of running water, no central heating and unreachable health care were cloaked in the supposed romanticism and heroism of the socialist regime. It was only after the collapse of the Soviet Union that oil production began to be portrayed as evil for the social and communal sector.

Lands': Potential for Legal Pluralism [Perspectives of the Indigenous Peoples and Law-makers]), in: Gosudarstvo i pravo 6 (2000), 105.

52 | "Za neft' platiat mukoi'" (Paid with Flour for Oil), in: Argumenty i fakty, 02.10.2002.

53 | Among several works in Russian some were published in English and even abroad, as for example: Gregory Vilchek/Olga Bykova: "The Origin of Regional Ecological Problems within the Northern Tyumen Oblast, Russia”, in: Arctic and Alpine Research 24:2 (1992), 99-107.

54 | A. I. Prishepa: "Gradostroenie v Surgute vo vtoroy polovine XX veka" (CityPlanning in Surgut in the Second Half of the $20^{\text {th }}$ Century), in: Otechestvennaya Istoria 2 (2007), 96. 
In the mid-199os, printed media and scientific literature opened a large-scale debate on the issue of associated gas flaring. ${ }^{55}$ Until now, this has been a major oil-related environmental problem in Russia as the Khanty Mansi Autonomous District (KMAO) is the world's leader in the amount of the associated gas explosions. This makes this West Siberian district the brightest spot on the world's map. Officially 20 billion cubic meter of associated gas is burned here every year, but Russian environmentalists estimate it being closer to 50 billion. Following this discursive theme and the 1994 oil spill in the city of Usinsk ${ }^{5}$, both media and scholarship pinpointed the lack of environmental awareness, typical for the oil sector ever since its foundation. This time, the discourse gained some apocalyptic rhetoric, which is well illustrated by a quote from a book published in 1995. Commemorating fathers of the West Siberian oil industry, it states: "We now again realize our connection to and dependence on nature and understand that a human being cannot survive without the biosphere." 57 As the prominent Russian mathematician and ecologist Nikolai Moiseyev once said: “The Cro-Magnon man managed to survive the ice age. But I am afraid, our civilization will not even be able to survive the real oil crisis that we are approaching." ${ }^{8}$ Similar utterances were also to be found in the printed media, for instance, in the weekly Argumenty $i$ Facty, which published an account of an enormous increase

55 | Associated gas is natural gas found dissolved in oil at the high pressures existing in a reservoir, and it can be present as a gas cap above the oil. Traditionally, this type of gas is released as a waste product of the oil extraction industry and burnt off in flares. Associated gas flaring produces ca. $1 \%$ of total global emissions of greenhouse carbon dioxide. The annual global volume of natural gas currently flaring is equivalent to $30 \%$ of natural gas consumption by the EU, $25 \%$ of U.S. consumption or $75 \%$ of Russian natural gas exports and results in the emission of 400 million tons of carbon dioxide. See À. Knizhnikov/N. Poussenkova: "Russian Associated Gas Utilization: Problems and Prospect”, WWF-Russia, Institute of World Economy and International Relations of RAN, Moscow, 2009, http://www. wwf.ru/data/pub/oil/poputnygaz_eng.pdf, Accessed: 23.09.2011.

56 | Usinsk's on the ground spill of around 100,000 tons of oil is the largest in history, and although the town is not situated in the West Siberian oil province, its notorious oil spill shook the entire discourse on fossil fuels and environment.

$\mathbf{5 7}$ | Krol: Neftianaya epopeya, 327.

58 | Nikolai Moiseev qtd. in Krol: Neftianaya epopeya, 329. 
in oncological diseases (over 90 percent), especially in lung cancer, in the Tyumen Oblast in the post-Soviet years. The article blames the authorities for allowing associated gas flaring and paying for the "black gold" with human lives. 59

\section{0s: Primacy of Economics and Neglected ECOLOGICAL Disasters}

Considering the increased environmental awareness of the early postSoviet discourse, it is strange that one notorious case of environmental damage caused by oil extraction still has not gained domestic publicity. In June 2000, the World Bank declared the West Siberian Samotlor oil field "an ecological disaster zone." ${ }^{60}$ This caused a lively debate on the environmental deterioration of Russia's 'Wild East' in the Western media and to some extent in Russian scholarship. ${ }^{61}$ However, the discursive shift towards the oil-related environmental damage barely took place in the Russian media. Right up to the present day, the oil discourse has been dominated by economic matters rather than environmental ones. Thus, within Russia the tragedy of Samotlor is regarded either as an outcome of the absent economic rationale ${ }^{62}$ or as a failure of the system to resist the interests of the Soviet elites. Most analysts simply regret that the oil deposit was ruined as several million tons of oil was not extracted due to

59 | Yuriy Zviagintsev: "Chernoye zoloto tsenoy zdorovia” (Paying with Health for the Black Gold), in: Argumenty i Facty, 15.08.1996, 3.

60 | Qtd. in West Siberia Oil Industry: “Environmental and Social Profile”, Final Report by IWACO BV Consultants for Water and Environment, June 2001, 63. http://www.greenpeace.org/raw/content/nederland-old/reports/west-siberia-oilindustry-envi.pdf, Accessed: 11.04.2010.

61 | See e.g. Oliver Morgan: "Black Cloud over BP Oil Deal," in: The Observer, 19.10.2003, http://www.guardian.co.uk/business/2003/oct/19/oilandpetrol.russia, Accessed: 22.06.2011 and Stanislav Meshcheryakov: "Environmental Problems in the Fuel-Energetics Complex of Russia," in: Chemistry and Technology of Fuels and Oils 36:2 (2000), 78.

62 | Viktor S. Smirnov: “Diskussii i Obsuzhdenia. Economicheskie Prichiny Krakha Sotsialisma v SSSR" (Discussions and Debates. Economic Reasons for the Collapse of Socialism in the USSR), in: Rossiiskaia Istoriia 6 (2002), 106. 
technological mistakes of the 1970s and 1980s. Until today, none of the investigated media sources have reported about the natural catastrophe caused by irrational exploitation. Not a single Russian source mentions the 6,500 hectares of heavily polluted soil or the people exposed to major health risks through contaminated drinking water and air. Only Western statistics document that in the last 5 years, 97 percent of the drinking water from the Vakh River has been contaminated with oil. ${ }^{63}$

Obviously the current discourse is focused on the destructive effect of the oil dependence on the national economy. Although by the late 1990s, Russian oil mining companies completed structural reforms and increased efficiency, the state underwent another type of restructuring. It became more dependent on oil prices than ever before. Since 1997 there has been a clear correlation between oil prices and Russia's economic growth. ${ }^{64}$ This is especially dangerous because petroleum is a commodity whose position on the market is subject to steep fluctuation cycles. Such strong dependence of the national economy on oil revenues and the resulting underdevelopment of its other branches are symptoms of the so-called Dutch disease. ${ }^{65}$ The Russian oil curse, namely the ease and speed with which oil revenues are received, makes the country unable to use such wealth to boost its economy. Together with the high rate of oil-related crime

63 | West Siberia Oil Industry: "Environmental and Social Profile".

64 | Fiona Hill: Energy Empire. Oil, Gas and Russia's Revival. London: The Foreign Policy Centre, 2004, 33.

65 | 'Dutch disease', also called the 'resource curse' or the 'curse of oil', is the damaging effect on an economy as a result of the exploitation and export of natural resources. Rapidly acquired resource wealth tends to give rise to a fight over existing resources, which in turn leads to poor institutional quality and lower growth. The argument here is that the large rents that can be obtained from natural resources create incentives for governments and private agents to engage in rent-seeking behavior, voracity and corruption, thus hindering entrepreneurial activity and other pro-growth activities. Recommended further reading: Nienke Oomes/Katerina Kalcheva: "Diagnosing Dutch Disease: Does Russia Have the Symptoms?", International Monetary Fund, WP/07/102 (2007), http://www.imf.org/external/pubs/ft/wp/2007/wp07102.pdf, Accessed: 08.09. 2011. 
and the approaching "end of oil history"66, this pathological dependence poses a threat to Russia's national economic security. Moreover, one of the complications of the Russian mutation of the Dutch disease has been a slowdown of institutional reforms. ${ }^{67}$ This has to do with the low demand for reforms on behalf of big business (mostly oil businesses) and insufficient reform offers from the state, since both parties are interested in maintaining the status quo, e.g. easy revenues from fossil fuels. In this respect, Russia resembles many emerging economies cursed by their wealth in natural resources. Governments that are not dependent on the wealth of the citizens just do not need to care about their own people and hope for the never-ending plenty of precious hydrocarbons.

The discovery of Siberian oil riches at the moment of dramatic economic decline of Brezhnev's stagnation era has set the trend of keeping the national economy afloat with the help of oil-export revenues. This habit had its ideological grounds in the Marxist-Leninist concept of natural resources, which challenges the very existence and gravity of environmental issues. Despite the fact that the 'green wave' of the 1980 s put environmental protection institutions in place, there has not been an environmental breakthrough in the oil debate.

West Siberian oil has been used to create an illusion of saving the country from an unavoidable collapse in the last decades of the Soviet rule. The illusion of oil plenty, deeply ingrained into people's minds through Soviet propaganda, lives on. Today, the exploitation of oil fields has become even more predatory than in the Soviet period and sustaining national economy by pumping more and more natural resources turned into an addiction. The traditional strategy of plundering West Siberia put the whole country on the 'oil needle'.

Although the discourse on oil-related environmental problems in Russia has grown over the past two decades, it has had little effect on the political action undertaken to make the industry cleaner and to effectively look for alternative energy sources. Despite the fact that science recognizes the environmental limits of oil extraction, politics, businesses and society

66 | Yuriy Latov: “Vliyanie neftegazovogo komplexa na national'nuyu economicheskuyu bezopasnost' Rossii" (Influence of Oil and Gas of Russia's National Economic Security), in: Terra Economicus 7:1 (2009), 101.

67 | Sergey Guriyev/Konstantin Sonin: “Economica 'resursnogo proklyatia'” (Economics of 'The Resource Curse'), in: Voprosy economiki 4 (2008), 65. 
do not wish to respect these limits. However, a functioning system of environmental protection potentially can pose hurdles to the traditionally extensive mining. The recognition by the government of the vital importance of the oil wealth for the national economy has had two dramatic results: deecologization of the state energy policy and of the energy mentality of the Russian people. And if the society remains indifferent to environmentally conscious energy policy, what are the chances that the state will become greener? As long as there are no structural improvements in the economy and no progress in the development of civil society in Russia, there will be no transition from a resource exploitive to a sustainable society.

\section{References}

\section{Primary Sources}

Alekperov, Vagit. "Zapadno-Sibirskoye 'Chernoye Zoloto” (West Siberian 'Black Gold'), in: Neftyanik Zapadnoy Sibiri, 31.10.2009, 1-2.

Alekseyev, Viktor. "Istoricheskiye Ocherki. Otkritiye Sibirskoy Nefti” (Historical Outlines. Discovering Siberian Oil), in: Voprosy Istorii 5 (1986), 68-79.

Astakhov, A. S./Khaitun, A. D./Subbotin, G. E. “Socio-economic Aspects of Oil and Gas Development in West Siberia”, in: Annual Review of Energy 14 (1989), 117-30.

Bogatko, Sergey/Chursin, Sergey. "Sopernichaya s Solntsem” (Competing with the Sun), in: Pravda, 30.06.1971.

Fedorova, Elena G. Rybolovy i Ochotniki Bassejna Obi: Problemy Formirovaniya Kul'tury Khantov i Mansi (Fishermen and Hunters of the Ob Bassin: Problems of Formation of Khant and Mansi Culture). Sankt-Peterburg: Evropejskiy Dom, 2000.

Gorbachev, Michail S. Izbrannie Rechi i Sta'i (Selected Speeches and Articles). Moskva: Politizdat, 1985.

Guriyev, Sergey/Sonin, Konstantin. “Economica 'resursnogo proklyatia” (Economics of “The Resource Curse”), in: Voprosy economiki 4 (2008), 61-74.

Lzvestiia, o8.11.1974.

“Kuda potechyot neft?” (Where Will the Oil Flow?), in: Pionerskaya Pravda, 13.12.1960, 1. 
Kulpin, Eduard/Yanitsky, Oleg. "Resursy i Perspectivy Ssocialno-ecologicheskoy Modernizatsii: Problemi Sibiri i Dalnego Vostoka” (Resources and Perspectives of the Socio-ecological Modernization: Problems of Siberia and the Far East), in: Rossia Reformiruyushayasya 7 (2008): 46392.

Latov, Yuriy. "Vliyanie neftegazovogo komplexa na national'nuyu economicheskuyu bezopasnost' Rossii” (Influence of Oil and Gas of Russia's National Economic Security), in: Terra Economicus 7:1 (2009), 91-104.

Meshcheryakov, Stanislav. "Environmental Problems in the Fuel-Energetics Complex of Russia," in: Chemistry and Technology of Fuels and Oils 36:2 (2000), 78-81.

Morgan, Oliver. "Black Cloud over BP Oil Deal," in: The Observer, 19.10.2003, http://www.guardian.co.uk/business/2003/oct/19/oilandpetrol.russia, Accessed: 22.06.2011.

Moshinskaya, Valentina I. Archeologicheskiye pamiatniki severa Zapadnoi Sibiri (The Artifacts of the North of West Siberia). Moskva: SAI, 1965.

Nosonovich, Nikolai. Nizhnevartovsk Tyumenskoi oblasti. Pisma v redaktsiyu (Readers' Letters), in: Voprosy Istorii 10 (1989-10-31), 171-78.

Novgorodov, Aleksey. "Istoricheskaia Nauka v SSSR. Retsenzii. M. E. Budarin. Put' Malykh Narodov Krai'nego Severa k Kommunizmu” (Historical Science in the USSR. Reviews. M. E. Budarin: The Road of the Small Peoples of the Far North to Communism), in: Voprosy Istorii 6 (1970), 134-36.

Novikova, N. I. “'Rodovyie Ugodia': Perspektivy Pravovogo Plzuralisma (Predstavlenia Predstavitelei Korennikh Narodov i Zakonodateley), ("Tribal Lands": Potential for Legal Pluralism [Perspectives of the Indigenous Peoples and Law-Makers]), in: Gosudarstvo i pravo 6 (2000), 102-07.

Postanovlenie CK KPSS, Sovmina SSSR ot 07.01.1988, N32 "O Korennoy Perestroike Dela Okhrany Prirody v Strane" (Decree of the Central Committee of the CPSU and the Soviet of Ministers of the USSR from 17.01.1988, No. 32 "On the Fundamental Reorganization of Nature Protection in the Country"), paragraph 24, http://base.consultant.ru/cons/ cgi/online.cgi?req=doc;base=ESU;n=770, Accessed: 06.09.2011.

Prishepa, A. I. "Gradostroenie v Surgute vo Vtoroy Polovine XX veka" (CityPlanning in Surgut in the Second Half of the $20^{\text {th }}$ Century), in: Otechestvennaya Istoria 2 (2007), 95-100. 
Program of the Communist Party of the Soviet Union. New York: International Publishers, 1963.

Sangi, Vladimir/Dmitrieva, Anna. “Spasti Narodnosti Severa, Sokhranit' Ikh Kul'turu" (Save the Ethnic Groups of the North and Preserve Their Culture), in: Voprosy Literatury 3 (1989), 3-29.

Shestalov, Yuvan. "S vysoty rodnogo ochaga" (From the Height of My Native Hearth), in: Pravda, 20.11.1985, 3.

Smirnov, Viktor S. "Diskussii i obsuzhdenia. Economicheskie prichiny krakha sotsialisma v SSSR” (Discussions and Debates. Economic Reasons for the Collapse of Socialism in the USSR), in: Rossiiskaia istoria 6 (November 2002), 91-110.

Sotsialisticheskaia Industriia, 28.11.1974.

“Sverkhplanovaya Neft" (Oil Beyond Plan), in: Trud, 05.11.1987.

Transcript of the meeting at the office of the USSR Chairman of the Council of Ministers comrade Ryzhkov N. I. "O Postavke dlia Gosudarstva Nefti, Gazovogo Kondensata i Nefteproduktov v 1991 godu” (On the State Supplies of Oil, Gas Condensate and Oil Products in 1991), 17.09.1990, State Archive of the Russian Federation, F. 5446, Op. 162, D. 379, L. 143 .

Vilchek, Gregory/Bykova, Olga. “The Origin of Regional Ecological Problems within the Northern Tyumen Oblast, Russia”, in: Arctic and Alpine Research 24:2 (1992), 99-107.

Vneshniya Torgovlya SSSR (Foreign Trade of the USSR), for the years 1966-1988, Ministry of Foreign Trade, Moskva: Statistica.

Vorontsov, Nikolai. “Dlia Nas i Potomkov. Okhrana Prirody do Lysenko, Berii, pri Nikh i Segodnia” (For Us and Our Descendants. Nature Protection before Lysenko, Beria, at Their Time and Today), in: Izvestia 228 (1989), 3 .

Vystuplenie Gromyko na Shestoy Spetsialnoy Sessii Generalnoy Assamblei OON (Gromyko's Speech at the Sixth Special Session of the UN General Assembly), in: Pravda, 12.04.1974, 4.

West Siberia Oil Industry. "Environmental and Social Profile, Final Report", June 2001, IWACO BV Consultants for Water and Environment, http://www.greenpeace.org/raw/content/nederland-old/reports/westsiberia-oil-industry-envi.pdf, Accessed: 11.03.2011.

"Za Neft' Platiat Mukoi”" (Paid with Flour for Oil), in: Argumenty i Facty, 02.10 .2002 . 
Zviagintsev, Yuriy. "Chernoye zoloto tsenoy zdorovia” (Paying with Health for the Black Gold), in: Argumenty i Facty, 15.08.1996.

\section{Secondary Sources}

Balzer Mandelstam, Marjorie. “The Tension between Might and Rights: Siberians and Energy Developers in Post-Socialist Binds", in: Europe-Asia Studies 58:4 (June 2006), 567-88.

Bruno, Andy. "Russian Environmental History: Directions and Potentials", in: Kritika: Explorations in Russian and Eurasian History 8:3 (2007), 63550.

Dryzek, John S. The Politics of the Earth: Environmental Discourses. New York: Oxford University Press, 1997.

Gestwa, Klaus. Die „Stalinschen Großbauten des Kommunismus“. Sowjetische Technik- und Umweltgeschichte, 1948-1964. München: Oldenbourg, 2010.

Gaydar, Egor. Gibel' Imperii. Uroki dlia Sovremennoi Rossii (The Collapse of an Empire: Lessons for Modern Russia). Moskva: Rosspen, 2006.

Hill, Fiona. Energy Empire. Oil, Gas and Russia's Revival. London: The Foreign Policy Centre, 2004.

Hopkins, Arthur T. Unchained Reactions: Chernobyl, Glasnost, and Nuclear Deterrence. Washington, DC: National Defense University Press, 1993.

Kazantsev, Sergey, ed. Energia Ugry: Istoki (Energy of Yugra: the Roots). Vol. 4: Vsem Mirom (All Together). Yekaterinburg: Parkus, 2002.

Knizhnikov, A./Poussenkova, N. "Russian Associated Gas Utilization: Problems and Prospects". WWF-Russia, Institute of World Economy and International Relations of RAN, Moscow, 2009, http://www.wwf. $\mathrm{ru} /$ data/pub/oil/poputnygaz_eng.pdf, Accessed: 23.09.2011.

Krol, Matvey, ed. Neftianaya Epopeya Zapadnoy Sibiri (The Oil Epic of Western Siberia). Moskva: Parnas, 1995.

Larin, Vladislav/Mnatsakanyan, Ruben/Chestin, Igor/Shwarts, Evgeniy. Okhrana Prirody Rossii: ot Gorbacheva do Putina (Russia's Nature Protection: From Gorbachev to Putin). Moskva: KMK, 2003.

Odum, Eugene. Ecology. 2 Vols. 1963, translated from English. Moskva: Mir, 1986.

Oomes, Nienke/ Kalcheva, Katerina. “Diagnosing Dutch Disease: Does Russia Have the Symptoms?”. International Monetary Fund, WP/O7/102 (2007), http://www.imf.org/external/pubs/ft/wp/2007/wpo7102.pdf, Accessed: 08.09.2011. 
Papp, Daniel S. “Marxism-Leninism and Natural Resources: The Soviet Outlook", in: Resource Policy 3:2 (1977), 134-48.

Ryzhkov, Nikolai I. Desyat Let Velikikh Potryaseniy (Ten Years of Great Distress). Moskva: Assotsiatsiya “Kniga, Prosvyashenie, Miloserdie”, 1995.

Sagers, Matthew J./Green, Milford B. “Transport Constraints in Soviet Petroleum”, in: Energy Policy 13:4 (1985), 371-80.

Sirina, Anna. "Oil and Gas Development in Russia and Northern Indigenous Peoples", in: Elana Wilson Rowe, ed. Russia and the North. Ottawa: University of Ottawa Press, 2009, 187-203.

Slavkina, Maria. Triumf $i$ tragedia: razvitie neftegazovofo kompleksa SSSR v 1960-1980-e godi (Triumph and Tragedy: Development of the Oil and Gas Complex in the USSR 196os-1980s), Moskva: Nauka, 2002.

—. "Istoria Prinyatiya Reshenia o Promyshlennom Osvoenii Zapadnoi Sibiri" (History of Decision Making on Industrial Development of West Siberia), in: Economicheskaya Istoria 10 (2005), 146-62.

Worster, Donald, ed. The Ends of the Earth. Perspectives on Modern Environmental History. Cambridge: Cambridge University Press, 1988. 



\title{
Publics in the Pipeline
}

\author{
On Bioenergy and its Imagined Publics in
}

Norway and Sweden

Tomas Moe Skjølsvold

In 2009, I attended the Norwegian Bioenergy Days - a conference where the bioenergy industry gathered to discuss the state of their bioenergy fuels, technology and markets. ${ }^{1}$ Recurring themes at the conference were red numbers, difficult markets and bankruptcies. Many participants had a bleak outlook because they were unable to generate profits. One presenter asked: "Is something going to happen soon, or should we find another industry?" 2 The discussions circled around flawed policy, but also around the relationship between bioenergy and competing technologies. ${ }^{3}$ The conference participants claimed that other renewable energy technologies like wind and solar power were seen as better alternatives to bioenergy. This, they claimed, was reflected in the media coverage on bioenergy and in the way politicians spoke of it. Most importantly, they pointed to a broader

1 | The Norwegian bioenergy industry is quite small, but includes players working with many fuels and technologies like pellets, wood chips, biogas, biodiesel and ethanol. See Norsk Bioenergiforening: Bioenergi i Norge. Oslo: Nobio, 2010.

2 | Geir Skjervak: “Kvar Blir det av det Store Pelletsløftet i Noreg?”, Conference paper, “Bioenergidagene 2009”, Rica Nidelven Hotell, 23.-24.11.2009.

3 | 'Bioenergy' refers to energy derived from biological sources. It is considered a renewable form of energy and often highlighted in policies, meant to increase the share of renewable energy technologies. See e.g. European Parliament: "Directive 2009/28/EC of the European Parliament and of the Council of 23 April 2009 on the Promotion of the Use of Energy from Renewable Sources", in: Official Journal of the European Union, 05.06.2009. 
collective referred to as 'the public's as either unaware of the possibilities offered by bioenergy or holding negative attitudes towards it.

From an industry perspective, bioenergy had an image problem. The industry's concerns about public ignorance and negative attitudes paved the way for presentations about how they could engage the public to improve the perception of bioenergy. As an outsider observing from a science and technology studies perspective, I found this illuminating. The bioenergy industry's efforts to improve the reputation of bioenergy are examples of what Bruno Latour and others refer to as translation; that is strategies to enlist and interest others to their technology. ${ }^{5}$ Thus, the conference participants had moved beyond the ideas postulated in the linear models of innovation and diffusion where the success or failure of technologies is largely seen as determined by the technology's technical and economic properties. ${ }^{6}$ Rather, the participants proposed translation strategies that sought to attach bioenergy to positive symbolic universes, for example through presenting it as a futuristic, simple, climate friendly or economically sound competitor to other energy technologies. ${ }^{7}$

4 | 'The public' as a concept has a long tradition in philosophy and political science. See e.g. Jürgen Habermas: The Structural Transformation of the Public Sphere. Cambridge, MA: MIT Press, 1989. In my paper, I use the notion of 'the public' as it appears in the literature on 'Public Understanding of Science and Technology'. Here, 'the public' is used pragmatically, to describe actors implicated by scientific or technological activity. For more, see the section entitled "From Publics to Imagined Publics" in this paper.

5 | Bruno Latour: Science in Action. Cambridge, MA: Harvard University Press, $1987,132$.

6 | The linear model of innovation's origin is unclear. See Benoit Godin: "The Linear Model of Innovation. The Historical Construction of an Analytical Framework", in: Science, Technology \& Human Values 36:4 (2006), 639-67 for a discussion of how the model has shaped thinking on innovation and technology diffusion over the last 50 years.

7 | E. g. Anne Jordal: "Korleis Utvikle og Lansere Meir Konkurransedyktige Pelletskaminar?", Conference paper, “Bioenergidagene 2009”, Rica Nidelven Hotell, 23.-24.11.2009, discussed framing pellet ovens as 'future heat' or 'automated stoves' arguing that this would convince 'the public' about the environmental potential and convenience of pellet heaters. These symbolic frames would bring customers to pellets who would otherwise buy air-to-air heat pumps. 
Inspired by this, the point of departure for this paper is an interest in the development of such strategies. Specifically, I am interested in the rationale behind their formulation. In most presentations at the conference this rationale was anchored in beliefs about the nature of the collective referred to as 'the public' and beliefs about 'public' perception of bioenergy. In this paper, I examine the relationship between the bioenergy industry and this collective from the perspective of industry actors, policy and decision makers. Empirically, I will examine two questions:

1. How do the actors who work to improve the position of bioenergy perceive this collective? How do they imagine 'the public'?

2. How do such imagined publics influence the formulation of strategies of public engagement?

I pursue these questions comparatively, looking at Norway and Sweden. The paper is based on fieldwork from these countries conducted in 20092010, and on studies of newspapers from 2007-2009.

The paper is structured as follows. I set out to outline the theoretical foundations of the concept 'imagined publics', before looking at earlier studies of imagined publics of renewable energy. I proceed to present the paper's methodology before examining the context for this discussion: Norway and Sweden as energy regimes, focusing on bioenergy. Also, a brief analysis of how Norwegian and Swedish newspapers have covered bioenergy is presented. I then move on to the discussion on bioenergy and its imagined publics in Norway and Sweden.

\section{From Publics to Imagined Publics}

For the last 25-30 years a body of literature has been engaged with what has been labelled 'public understanding of science and technology' (PUS). ${ }^{8}$ This line of thought emerged in response to the influence of 'the

8 | Steve Miller: "Public Understanding of Science at the Crossroads", in: Public Understanding of Science 10:1 (2001), 115-20 dates the start of this intellectual tradition to a publication by the Royal Society in the UK entitled "The Public Understanding of Science" from 1985. 
deficit model of public understanding' ${ }^{9}$ Here, public opposition to and concerns about scientific and technological development is rooted in a lack of public knowledge or understanding of science and technology. ${ }^{10}$ Thus, technologies or science are not seen as problems, 'the public' is. A typical policy response to this understanding of public agency has been to employ top-down approaches to by-pass public concerns. ${ }^{11}$

This has been criticized by the PUS literature, first by a call for attention to possible 'public' participation in science and technology ${ }^{12}$, a critique highlighting "opposition between technocracy and public participation."13 Now the idea of public participation has been refined to the point where 'participation' is no longer necessarily a goal, but one of many forms of 'public engagement' with science and technology. ${ }^{14}$ Recently, scholars have found 'engagement' with the public to be an industry and government norm, particularly for those working with controversial science or technology. 15

9 | See Alan G. Gross: "The Role of Rhetoric in the Public Understanding of Science”, in: Public Understanding of Science 3:1 (1994), 3-23 for a discussion on this model's influence.

10 Steve Rayner: "Democracy in the Age of Assessment: Reflections on the Roles of Expertise and Democracy in Public-Sector Decision Making”, in: Science and Public Policy 30:3 (2003), 163-70.

11 | E.g. John Durant: "Participatory Technology Assessment and the Democratic Model of the Public Understanding of Science", in: Science and Public Policy 26:5 (1999), 313-19.

12 | E.g. Edna F. Einsiedel/Erling Jelsøe/Thomas Breck: "Publics at the Technology Table: The Consensus Conference in Denmark, Canada and Australia", in: Public Understanding of Science 10:1 (2001), 83-98 or Heather Dietrich/Renato Schibeci: "Beyond Public Perceptions of Gene Technology: Community Participation in Public Policy in Australia", in: Public Understanding of Science 12:3 (2003), 381-401.

13 | Noortje Marres: "The Issues Deserve More Credit", in: Social Studies of Science 37:5 (2007), 766.

14 | Gene Rowe/Lynn J. Frewer: “A Typology of Public Engagement Mechanisms", in: Science, Technology and Human Values 30:2 (2005), 251-90.

15 | Related to renewable energy see Julie Barnett/Kate Burningham/Gordon Walker/Noel Cass: "Imagined Publics and Engagement around Renewable Energy Technologies in the UK", in: Public Understanding of Science, published 
A related question deals with how industry and policy makers formulate strategies of public engagement - and further, about the rationale behind their formulation. These are the questions that primarily interest me in this paper. One way to address this is to look for subtle and indirect links between collectives like 'the public', the industry and policy makers. Inspired by what Allesandro Maranta and colleagues coined 'imagined laypersons ${ }^{16}$ in a discussion of how experts think non-experts relate to their activity, a recent strain of literature has studied such matters via the idea of 'imagined publics' ${ }^{17}$ Their premise is simple. These authors claim that 'the public' does not only carry agency through action. Rather, 'the public' is also powerful as an idea. When industrialists and policy makers make decisions, they do so in light of an imagined public response. ${ }^{18}$ Imagined publics give life to "shared repertories and expectations amongst actors in technical-industrial networks", expectations which are "anticipated and internalised into organisational practices and working practices." ${ }^{19}$ Thus, there is reason to believe that while studying the Norwegian and Swedish

online before print on June 30, 2010, http://pus.sagepub.com/content/early/2010/06/21/0963662510365663.abstract, Accessed: 15.12.2011.

16 | Allesandro Maranta/Michael Guggenheim/Priska Gisler/Christian Pohl: “The Reality of Experts and the Imagined Lay Person", in: Acta Sociologica 46:2 (2003), 150-65.

17 | E.g. Brian Wynne: "Reflexing Complexity. Post-genomic Knowledge and Reductionist Returns in Public Science”, in: Theory, Culture and Society 22:5 (2005), 67-94.

18 | These ideas are not entirely new. In 1927, John Dewey wrote that political orders "impute a public only to support and substantiate the behaviour of officials" - thus, publics are imagined to legitimate and give substance to government systems. Dewey cited in Rebecca Ellis/Claire Waterton: "Environmental Citizenship in the Making: The Participation of Volunteer Naturalists in UK Biological Recording and Biodiversity Politics", in: Science and Public Policy 31:2 (2004), 103.

19 | Gordon Walker/Noel Cass/Kate Burningham/Julie Barnett: “Renewable Energy and Sociotechnical Change: Imagined Subjectivities of 'the Public' and Their Implications", in: Environment and Planning 42:4 (2010), 943. 
bioenergy industry, I will find links between their imagined publics and their actual practice of public engagement. ${ }^{20}$

Studies of imagined publics are particularly pertinent if the science or technology is controversial. Earlier studies show that renewable energy projects generally ${ }^{21}$ and bioenergy projects particularly ${ }^{22}$ are prone to controversy; frequently surrounded by supporters, protesters and debate. This is probably why there already exist a number of studies dealing with the imagined publics of renewable energy technology. What can be learned from these studies?

Most existing literature is concerned with the imagined publics of the renewable energy industry in the UK. Gordon Walker and Noel Cass argue that prior to the liberalisation of the UK energy utilities and infrastructure in 1989 , 'the public' was imagined as “'end-of-wire' captive consumers."23 Following the liberalisation and the tailing variety in modes of energy production, the importance of 'the public' has increased and its roles have multiplied. The authors identify publics imagined as captive consumers, active consumers, service users, green investors, local beneficiaries, project protestors, project supporters, project participants, technology hosts and energy producers. ${ }^{24}$ This plurality is reflected elsewhere. Kate Burningham and colleagues found publics imagined as 'users' or as

20 | Several studies dealing with 'public perception' of bioenergy exist. Typically, they use quantitative methods to measure 'public attitudes' towards bioenergy. E.g. Henrik Karlstrøm: Den Deregulerte Forbruker. Trondheim: Institutt for Tverrfaglige Kulturstudier, 2010 finds roughly 70 percent of Norwegians to be positive towards bioenergy. A focus on 'imagined publics' complements this approach, by showing how public imaginaries inform industrial behaviour.

21 | Gordon Walker: "Renewable Energy and the Public", in: Land Use Policy 12:1 (1995), 49-59.

22 | Bishnu Raj Upreti/Dan van der Horst: “National Renewable Energy Policy and Local Opposition in the UK: The Failed Development of a Biomass Electricity Plant", in: Biomass and Bioenergy 26:1 (2004), 61-69.

23 | Gordon Walker/Noel Cass: “Carbon Reduction, 'the Public' and Renewable Energy: Engaging With Socio-Technical Configurations”, in: Area 39:4 (2007), 466.

24 | Walker: “Carbon Reduction, 'the Public' and Renewables”, 465. 
'neighbours'. ${ }^{25}$ Julie Barnett and colleagues ${ }^{26}$ found publics imagined as ignorant or concerned about renewable energy developments and that the renewable energy industry imagined the public through the 'deficit model of public understanding'. ${ }^{27}$ This public imaginary, the authors claim, led to the formulation of strategies of public engagement meant to educate the public, and to rectify public concerns. Similarly, Gordon Walker and colleagues $^{28}$ found the renewable energy industry to imagine its publics as opposed to renewable energy based on the NIMBY ('not in my back yard') concept. ${ }^{29}$ Thus, the industry sees publics mostly as hostile obstacles to their development. To summarize past research on imagined publics of renewable energy, Dandy Norman's words seem fitting: “The actors in the renewable energy industry have a strong tendency to define 'the public' as 'concerned". Further, he notes that this has "strong impacts on the 'engagement' activities" of the actors involved. . $^{\circ}$

Based on the studies from the UK cited above, it is likely that the study of the Norwegian and Swedish bioenergy players will reveal a plurality of imagined publics. One way to categorise this plurality is Mike Michael's differentiation between 'publics in particular' (PiPs) and 'publics in general' (PiGs)..$^{31}$ While discussing publics in relation to science, his argument

25 | Kate Burningham/Julie Barnett/Anna Carr/Roland Clift/Walter Wehrmeyer: "Industrial Constructions of Publics and Public Knowledge: A Qualitative Investigation of Practice in the UK Chemicals Industry", in: Public Understanding of Science 16:1 (2008), 23-43.

26 | Barnett: "Imagined Publics and Engagement in the UK".

27 | Gross: "The Role of Rhetoric in the Public Understanding".

28 | Walker: "Renewable Energy and Sociotechnical Change".

29 | The NIMBY concept has been criticised as a theoretical model for explaining negative attitudes towards renewable energy. However, empirical research suggests that NIMBYism is still understood by industrial players and policy makers as the main obstacle to renewable energy developments. See e.g. Patrick Devine-Wright: "Beyond NIMBYism: Towards an Integrated Framework for Understanding Public Perceptions of Wind Energy", in: Wind Energy 8:2 (2005), 125-39.

30 | Dandy Norman: Stakeholder Perceptions of Short-Rotation Forest for Energy. Farnham: Forrest Research, 2010, 11.

31 | Mike Michael: "Publics Performing Publics: Of PiGs, PiPs and Politics", in: Public Understanding of Science 18:5 (2009), 617-31. 
is that PiGs are defined in relation to 'science' in general while PiPs are defined in relation to particular scientific enterprises. As an example, 'science' has one public (PiG), while the human genome project has another (PiP). This differentiation is applicable also to bioenergy. 'Bioenergy' as a generic concept has one public (PiG), particular bioenergy enterprises such as a combined heat and power plant or a particular bioenergy company might have another (PiP). In Michael's account, PiPs tend to form around particular issues, resulting in publics having strong interests. Therefore, they are often either project protesters or project supporters. ${ }^{32}$ It will be interesting to see if Norwegian and Swedish bioenergy actors differentiate between PiPs and PiGs, and whether or not they have moved beyond imagining the public through the deficit model of public understanding.

\section{Methodology}

The methodology mobilized here is two-fold. First, I set out to analyse how Norwegian and Swedish newspapers cover bioenergy. By studying 437 Norwegian and 598 Swedish newspaper articles ${ }^{33}$, I shed light on how bioenergy is communicated in contemporary Norway and Sweden. This information is used to generate hypotheses about Norwegian and Swedish bioenergy actors and their imagined publics.

The second source of data consists of interviews with 44 persons in Norway and Sweden ${ }^{34}$, six issues of the Norwegian professional journal

32 | Walker: “Carbon Reduction, 'the Public' and Renewable Energy”.

33 | Three Norwegian and Swedish newspapers were accessed. The Norwegian papers were Adresseavisen, Aftenposten and Verdens Gang; the Swedish were Östgöta Correspondenten, Svenska Dagbladet and Aftonbladet. The papers were accessed via the media database Retriever.

34 | All interviews used as data for this paper was carried out by the author with the exception of three Norwegian interviews conducted together with Gard $\mathrm{H}$. Hansen. The interviews were conducted in Norwegian and Swedish. All quotes in this paper, both from interviews and written sources have been translated to English by the author. The interviewees have been anonymized and are presented with pseudonyms. 
Bioenergi35 and six issues of the Swedish equivalent journal ${ }^{36}$ (also named Bioenergi). The interviewees were players in the bioenergy industry, public employees and decision makers working with bioenergy as well as scientists working with bioenergy. The interviews were 40 minutes to two hours long and recorded and transcribed before they were coded and analysed. The analysis and coding were inspired by Grounded Theory. 37 Here, pieces of data are compared with each other and with the emergence of similarities and differences, groups of categories are formed. These categories form the basis for the analysis of how the Norwegian and Swedish bioenergy actors imagine the publics of bioenergy.

\section{The Need to Introduce Bioenergy: Norway and Sweden as Energy Regimes}

Norway and Sweden are ideal contrasts since they represent different 'energy regimes'. In Norway, almost all electricity is hydropower. ${ }^{38}$ Much of this is used for space heating. ${ }^{39}$ In principle, this stationary energy base is 'green', which could indicate that there is little need to introduce bioenergy. Two aspects complicate this. First, Norway is actually a net importer of electricity in a 'normal' year ${ }^{\circ}$, which means that the consumed electricity

35 | Bioenergi: 3-6, 2009 and 1-3, 2010. Professional journal published by the Norwegian bioenergy association.

36 | Bioenergi: 3-6, 2009 and 1-3, 2010. Professional journal published by the Swedish bioenergy association.

37 | Anshelm Strauss/Juliet M. Corbin: Basics of Qualitative Research: Grounded Theory Procedures and Techniques. Newbury Park, CA: Sage, 1990.

38 | IEA Energy Statistics: “Electricity/Heat in Norway in 2008”, 2008, http:// iea.org/stats/electricitydata.asp?COUNTRY_CODE=NO, Accessed: 01.09.2011.

39 | Norway uses the largest share of electricity for space heating of all countries studied by the IEA. See Fridtjof Unander/Ingunn Ettestøl/Mike Ting/ Lee Schipper: "Residential Energy Use: An International Perspective on LongTerm Trends in Denmark, Norway and Sweden”, in: Energy Policy 32:12 (2004), 1395-1404.

40 | Marit Tyholt/Anne Grete Hestnes: "Heat Supply to Low-Energy Buildings in District Heating Areas: Analysis of $\mathrm{CO}_{2}$ Emissions and Electricity Supply Security", in: Energy and Buildings 40:2 (2008), 131-39. 
is not necessarily 'green'. Second, there has been an increased focus on energy efficiency and energy quality. In this perspective, it is better to use electricity for purposes other than space heating. ${ }^{41}$ Thus, bioenergy has primarily been given political attention in Norway as a potential replacement for space heating based on hydroelectricity. ${ }^{42}$ Parliament representative Trond Martin Sæterhaug summarized this notion in 2009 stating that "using electrical power for space heating is like bathing in champagne." 43

Despite its 'green' and 'efficient' qualities, bioenergy is a marginal technology in Norway with an annual consumption of $14.5 \mathrm{TWh}^{44}$ or around 6 percent of all energy consumed. ${ }^{45}$ Even if the goal of doubling this by $2020^{46}$ is met, it will remain a niche, a modest addition to the Norwegian energy total. Instead, the major Norwegian energy-political effort over the last years has been geared towards developing carbon capture and storage (CCS) and the employment of this in gas power plants. ${ }^{47}$

The Swedish situation is different with a historically more diverse energy production. Fossil fuels, hydroelectricity, and nuclear power have

41 | Ivar S. Ertesvåg/Michael Mielnik: "Exergy Analysis of the Norwegian Society”, in: Energy 25:10 (2000), 957 say: “The notion of energy quality follows from the second law of thermodynamics. Some forms of energy can be converted into any other form, whereas other forms cannot. Electricity can be converted into mechanical work or into heat. For practical purposes, hot-water thermal energy can most often only be used for heating. On the other hand, for space heating hot waste-water suffices, whereas an aluminium plant requires electrical energy."

42 | Olje og Energidepartementet: Strategi for økt utbygging av bioenergi, Oljeog Energidepartementet, 2008, http://www.regjeringen.no/upload/OED/Bioenergistrategien2008w.pdf, Accessed: 04.07.2011.

43 | Håkon Arntsen/Sivert Rossing: "Fikk 15 Millioner til Strømsparing i Fylket", in: Trønderavisa, 15.09.2009.

44 | Olje og Energidepartementet: Strategi for økt utbygging av bioenergi, 7.

45 | This number includes the transport sector. See Statistisk Sentralbyrå: “Energi". http://www.ssb.no/energi/, Accessed: 01.09.2011.

46 | Olje og Energidepartementet: Strategi for $ø$ kt utbygging av bioenergi, 12.

47 | Andreas Tjernshaugen: "Fossil Interests and Environmental Institutions: The Politics of $\mathrm{CO}_{2}$ Capture and Storage" (Unpublished Ph.D diss. Universitetet i Oslo, 2009). 
all been important..$^{8}$ Today, Sweden has one of the highest consumption rates of bioenergy in the world. ${ }^{49}$ Bioenergy started to receive attention in Sweden in the 1970s. It was first seen as a means to rid Sweden of its dependence on foreign fossil fuels and nuclear power, and later as a tool to mitigate climate changes..$^{\circ}$ Bioenergy broke through to the mainstream of Swedish energy technologies in the early $1990 \mathrm{~s}^{51}$, a decade characterised by a 'greening' of the Swedish welfare state. It has been at the core of Swedish energy policy since $1997^{52}$, acting as a 'politically harmonizing technology' by bridging a gap that existed between advocates of nuclear power and renewable energy technologies. ${ }^{53}$ Today, bioenergy accounts for roughly one third of the total Swedish consumption. Its share is larger than fossil fuels, nuclear power and hydroelectricity. ${ }^{54}$

Thus, the roles of bioenergy in Norway and Sweden are substantially different. In Norway, it is a niche technology, primarily introduced to replace electricity for space heating. In contrast, it is at the core of Swedish energy policy and is currently the largest energy-producing technology in this setting. How will these circumstances influence the imagined publics of bioenergy in Norway and Sweden? To generate hypotheses about this, I will now look briefly at how Norwegian and Swedish newspapers have covered bioenergy.

48 | See e.g. Arne Kaijser/Marika Hedin: Nordic Energy Systems. Historical Perspectives and Current Issues. Canton, MA: Watson Publishing International, 1995.

49 | Energimyndigheten: Energiförsörjingen i Sverige. Energimyndigheten, 2009.

50 | Jonas Anshelm: Att ersätta kärnkraften med bioenergi - om en omstridd idé i den offentliga energipolitiska debatten i Sverige 1979-2000. Linköping: Tema T, Linköpings Universitet, 2009; Ann-Sofie Kall: “Förnyelse med förhinder” (Unpublished Ph.D diss. Linköpings Universitet, 2011).

$\mathbf{5 1}$ | Kall: Förnyelse med förhinder, 143-99.

$\mathbf{5 2} \mid$ E.g. Atle Midttun/Mari Hegg Gundersen/Anne Louise Koefoed: “Greening of Nordic Electricity Industry: Policy Convergence and Diversity”, in: Energy \& Environment 15:4 (2004), 633-56.

53 | Kall: Förnyelse med förhinder, 172.

54 | Energimyndigheten: Energiförsörjingen i Sverige, 35. 


\section{Broadening the Context: Norwegian and Swedish Media Coverage of Bioenergy}

The reading of the analysed newspapers shows substantial differences between the coverage of bioenergy in Norway and Sweden. In summary, the Swedish newspapers are more supportive of bioenergy than the Norwegian. The Swedish newspapers support bioenergy through presenting it as 'green' or 'environmentally friendly'55, but also as competitive in other ways. Bioenergy is presented as a safe and comfortable technology ${ }^{56}$ that has brought wealth and prosperity to local communities..$^{57}$ It is frequently described in patriotic terms, as a 'Swedish' way of being green, an area where the rest of the world seeks Swedish aid..$^{8}$ In summary, the technology is presented as good for the wallet, good for the climate, and good for Sweden.

The Norwegian press is less supportive. It does not portray bioenergy negatively, but with ambiguity and ambivalence. Bioenergy is presented as 'green'59, but this is not sufficient, because it is always compared with other energy technologies that are seen as technically and economically superior. ${ }^{60}$ In other words, the Norwegian story about bioenergy is a story

55 | Svenska Dagbladet: Satsar Stenhårt på att Förse Polen med Miljövennlig Fjärrvarme, 29.07.2009 is a typical example highlighting the 'green' aspect of the technology.

56 | E.g. Svenska Dagbladet: Elda snyggt och säkert, 12.12 .2009 notes how bioenergy heating solutions are better than other solutions at providing heat, but also in terms of aesthetics and safety.

57 | E.g. Östgöta Correspondenten: Linköpingsföretag gör Milliardaffär, 05.06.2010 discusses bioenergy primarily as a local-industrial stimulant and generator of wealth.

58 | E.g. Östgöta Correspondenten: Sydkoreansk Stad vill Lära av Linköping, 12.05.2010 shows how a South-Korean town wants to learn from a Swedish town, while Östgöta Correspondenten: Världsnaturfonden Lyfter Fram Linköpingsföretag, 30.09.2010 highlights how the World Wildlife Fund praised a Swedish bioenergy company.

59 | E.g. Aftenposten: Lover mer enn Enoksen, 22.09.2007 portrays bioenergy as the 'green coal of the future'.

60 | Adresseavisen: Spår Vannkraft-Boom i Norge, 25.09.2009 suggests that hydroelectricity and gas power-plants are the future while Adresseavisen: Søker 
about a 'green' technology, but as energy technology it is seen as falling short based on technical and economic arguments.

Furthermore, bioenergy was described in the newspapers with a third set of arguments in both countries. The production of bioenergy was cast against the production of food, resulting in bioenergy being framed as a controversial symbol of the North's dominance over the South. ${ }^{61}$

How does all of this influence the investigation of imagined publics of bioenergy in Norway and Sweden? First, earlier research has found publics imagined as 'concerned' about or opposed to renewable energy developments ${ }^{62}$, framed through the deficit model of public understanding. ${ }^{63}$ In the following, I expect to find such imagined publics in both Norway and Sweden. Second, the role of bioenergy differs in Norway and Sweden. As a marginal Norwegian technology, its expansion will be accompanied by the construction of facilities changing landscapes, creating noise and smell, increasing traffic and creating other controversial side-effects. The ambivalent Norwegian newspaper coverage might be a hint of such controversy. There is less of this in Sweden, since much infrastructure needed to distribute bioenergy is already in place. Thus, I expect publics explicitly imagined through mobilisation of the NIMBY concept in Norway while I believe there will be less of this in Sweden. Third, the patriotic coverage of bioenergy in Swedish newspapers and the position of bioenergy in Sweden suggest publics to be imagined more positively.

om forlengelse, 22.12.2008 writes that compared to competing technologies bioenergy is 'unsuitable'.

61 | Verdens Gang: Matvaregiganter i Heftig Krangel, 10.08.2007, Aftenposten: Det Sier seg Selv at vi har et Problem, 11.09.2009, Aftonbladet, Etanolen Skövlar Naturen, 28.07.2007 and Svenska Dagbladet, Världensbanken Pekar på Biobrensle, 07.07 .2008 are all examples of coverage presenting bioenergy primarily as a competitor to food production.

62 | Barnett: "Imagined Publics and Engagement"; Walker: "Carbon Reduction, 'the Public' and Renewable Energy"; Walker: "Renewable Energy and Sociotechnical Change"; Norman: Stakeholder Perceptions.

63 | Gross: "The Role of Rhetoric in the Public Understanding". 


\section{Imagining the Publics of Bioenergy in NORWAY AND SWEDEN}

The interviewees in both countries had clear ideas about 'the publics' of bioenergy. Altogether five ideal typical domestic imagined publics were found; two Swedish and three Norwegian. Further, many Norwegian actors related their stories so explicitly to Sweden that they ended up imagining a Swedish public. As we shall see, the imagined publics frequently informed the bioenergy players' strategies of public engagement.

\section{The Local Publics}

In both countries, the most prominent imagined publics were 'local' publics. In Norway, local publics were imagined as 'neighbours' or 'protesters' of specific projects. Local publics were imagined as $\mathrm{PiPs}^{64}$ (publics in particular) with strong interests related to particular facilities, products or companies. As expected, these publics were regarded in light of the NIMBY concept and understood by the interviewees as selfishly concerned about how bioenergy developments would disturb local communities in terms of aesthetics and safety. This was related to issues like visual pollution, increased traffic, reduced air quality, foul smell, and so forth. One example was given by the manager of one of the largest Norwegian biogas facilities. He imagined the public in relation to the companies' experiences with the construction of a biogas plant a few years back:

"Well, we were not allowed to build the plant where we wanted. It was a political decision. [...] Basically the decision was based on fear. Fear of birds [and other vermin that the plant might attract, T. S.], smell, all kinds of stuff. The public was very much against us. There were demonstrations and we didn't really get the message across. It's not so easy when everyone is against you, and this is quite typical for our kind of operation." ${ }^{n 5}$

While some imagined the publics based on earlier interaction with groups of opponents, other accounts were anchored in what appeared as an industrial mode of 'common sense' regarding how publics of bioenergy act.

64 | Michael: "Publics Performing Publics: Of PiGs and PiPs".

65 | Interview with manager Andre Jørgensen in his office, 30.09.2009. 
For example, the head of a district heating company imagined the public as responding to their technology instinctively based on NIMBY logic:

"I think it's the same everywhere, at least for the technology we work with. Every time someone has a new project, there are these reactions, especially from the neighbours who begin with their protests as soon as they hear about it. It's not simple, of course. The public suddenly doesn't care so much about the climate and the environment when it comes to this." 66

The development of a bioenergy industry in Norway will affect local communities substantially through construction work. In many cases the result will be an altered landscape with new industrial facilities. As in the quotes above, the bioenergy industry imagines the publics as opposed to such development. This view often leads the industry to craft strategies of public engagement meant to limit the impacts of opposition. The manager of the district heating department of a large energy utility explained how engaging with the public was vital prior to announcing the construction of a new facility:

“Well, you can't just go ahead and say that you have decided about the location of a plant. For us, we take preliminary rounds with different departments at the administrative level, and we have meetings with the boards of various cooperative housing associations nearby, very lively meetings. Then we inform the municipal opposition, and then the board of the neighbourhood. We do all this before officially saying what we have decided, because keeping a dialogue with the public is considered important. Although all this takes some time, it minimizes the risk of having the regulation application thrown back in our faces with an answer of finding an alternative location." 67

The quote illustrates how 'public engagement' through communication at various levels is considered an industry norm. However, it is not done for the sake of the public. The goal is not public participation in the decision

66 Interview with manager Bernt Knutsen at district heating facility, 20.10.2009.

67 Interview with department manager Christian Haugen in his office, 12.10.2009. 
making process, the engagement is meant to limit the impact of expected opposition.

The local imagined publics in Sweden were different. These were not imagined as neighbours or protesters, but as passive consumers. As such, however, they were imagined as a group without a direct relationship to bioenergy. Instead, they were considered consumers of services, hooked up to an infrastructure where bioenergy was important. In other words, this public was imagined to buy heat, electricity, bus fares and cars, while bioenergy was imagined as 'invisible' to the public. The Swedish interviewees did not imagine publics via the NIMBY concept found in Norway or the UK. ${ }^{68}$ A manager at a large Swedish wood chips and pellet producer described the situation in this manner:

"The Swedish public, I guess, is largely positive towards bioenergy, or perhaps more precisely: it is ignorant about it. I mean, I don't think most people are aware of how important it is, and that it heats their homes and actually provides the light in their light bulbs. And I think this is a good sign - as long as it works, people don't care where the energy comes from." ${ }^{69}$

Similar sentiments were expressed by a market trader for stationary biofuels:

"The average Swede [...] does not care about bioenergy. He has a vague idea about it being something other than coal and fossil fuels, and the label 'bio' suggests that it is green. As long as it works, the Swede is quite happy."70

It is noteworthy that the interviewees did not see the imagined public's ignorance as a problem; in fact some respondents interpreted it as a seal of approval. A senior employee at the transport office of Linköping Municipality highlighted this by showing that the ignorance and approval had not always been there. When bioenergy was introduced, it was associated with occasional problems, resulting in bioenergy becoming the scapegoat:

68 | E.g. Walker: "Renewable Energy and Sociotechnical Change".

69 | Interview with manager Dan Eklund in his office, 07.04.2010.

70 | Interview in market trader Einar Carlström in his office, 20.04.2010. 
"People are not riding the bus because it is powered by biogas; they ride the bus because they need to go somewhere. And today, biogas works as well as any other fuel, and the air quality is much better now than when the buses used diesel. But in the beginning, there were some problems with the biogas buses. They did not work properly in the winter, and as you know it can be quite cold in Linköping during those months. And then some people certainly raised their voices against biogas." ${ }^{71}$

This illustrates the difference between imagining publics of novel, potentially controversial technology and of a smoothly working infrastructure. This point might seem trivial, but it suggests that while the technology improves, the nature of the relationships between 'publics' and industry changes. The imagined public is altered from active complainers to ignorant and unaware consumers. This also seems to have had an influence on how the industry players reflect on the need for public engagement. One interviewee highlighted that the most important thing they could do was to "produce as good services as we possibly can so that they stay happy."72 Another said it was important to "listen if the public reported any concerns." 73 In other words, public engagement appeared less important when the publics were not imagined as problems.

In summary, bioenergy in Sweden has been described as invisible and the publics imagined as blissfully ignorant. For the majority of bioenergy players, this was unproblematic. As we will see, however, there was one deviation from this way of framing the relationship between bioenergy and its publics. Here too, bioenergy was seen as an invisible aspect of daily life, but this was considered a democratic deficiency problem. The argument was that the public needed to know and understand the energy technology if they were to make informed decisions, a concern that was first and foremost raised by the Swedish bioenergy association through the industry journal Bioenergi. One article stated:

71 | Interview with senior employee Frederica Jansson in her office, 24.04.2010.

72 | Interview with manager Gunnar Lögnes in his office, 13.04.2010.

73 Interview with senior employee of company producing wood chips, Harald Ström at production site, 17.04.2010. 
"Ask your neighbour, your cousin or a large share of the Swedish public [...] and most will completely have missed the remarkable development that has happened and that continues today." 74

A similar article highlighted that the public should "wake up and realise how important bioenergy is." 75 This image of deficiency on behalf of the public was accompanied by voices highlighting that the public needed to be engaged through information. An editorial stated:

"First and foremost we want the energy authorities to do a better job when they present statistics so that journalists and others can do a good job when informing the public [...] [I]f this is not done we have to fill that gap [...] [I]n a democracy it is important that the public gets relevant or accurate information, or they cannot produce informed opinions." 76

Thus, where some saw the imagined publics' ignorance as unproblematic; others saw it as a problematic call for public engagement, primarily through strategies of information.

\section{The Public as Customers}

In both countries, I also discovered publics imagined as customers. These are examples of publics in particular, imagined in relation to specific bioenergy products. In Norway, such publics were understood via the deficit model of public understanding as ignorant and disinterested in relation to the products offered by the bioenergy industry. Here, the disinterest was seen as a problem for the industry since it was understood to result in nonconsumption.

This articulation of the public was particularly prominent amongst respondents working with pellets. These actors imagined their public as people in the market for a new heating solution. The interviewees claimed that this group was uninformed about the possibilities of bioenergy and

74 | Anders Haaker: “Är Bioenergi Något Nytt?”, in: Bioenergi 1 (2010), 9.

75 | Jan Ridfeldt/Gun Blomquist Bergman: "Underskatta Inte Bioenergins Betydelse!", in: Bioenergi 3 (2010), 44-45.

76 | Gustav Melin: “Kylan, Värmen och Elen”, in: Bioenergi 1 (2010), 11. 
therefore chose competing solutions. The manager of a leading pellets company framed the problem in the following way:

"We have tried everything to increase the sales, but it feels as difficult as cracking the DaVinci code. The problem for us is that people don't know about pellet heaters. The sales persons have to spend a lot of time explaining how they work, and the consumers take a long time to decide. For us, branding and information towards the public are prioritised tasks." 77

Similar sentiments were presented by a senior representative of a company that shortly before I interviewed them had decided to abandon the private market in favour of the municipal heating market. Public ignorance and lack of knowledge were highlighted as integral to the decision:

"Selling to municipalities and public agencies is one thing. They are professionals. They have engineers that make decisions and personnel such as janitors that can be trained. Individuals and normal households do not have this, so they generally tend to choose other solutions such as heat pumps - often because of misunderstandings." 78

Several respondents related the perceived knowledge deficit to aspects like lack of trust, familiarity or experience with the technology. Thus, they engaged the public to increase its knowledge of the technology. This was done through standard information and advertisement campaigns, but also through more direct engagement. In one case, a company tried to establish a new network of pellet users by providing the public with technology free of charge:

"We are trying to get the information directly to the customers. And we think that if they know someone who uses a pellet heater and is happy with it they might consider it themselves. So what we did was to produce flyers that we gave to every household in the region where we highlighted the benefits of pellets and promised that we would install pellet heaters and allow people to use them - free

77 | Interview with manager Ingrid Johnsen over the telephone, 22.07.2009.

78 Interview with senior representative Jan Andresen in company sales hall, 19.05.2009. 
of charge - for a period of time. If they were not happy, we would also collect the heater, free of charge." 79

When Swedish respondents imagined the public as customers, they did so differently. Their imagined public was quite local in character, probably due to the situation in the area where the interviews were conducted. The public as customers were not the imagined publics of 'bioenergy', but rather the imagined public of a cluster of companies and research institutions that worked with biogas.

This public was imagined as supportive of bioenergy both by politicians and companies with a regional profile. They clearly imagined the publics outside the deficit model of public understanding as a proud group of customers with a preference for 'green' products. The head of one large regional biogas company explained:

"The public is very interested in what we do, and I actually think they are somewhat proud of this company. This is one of the few things that we here at this little place are best at in the world, and I have the feeling they appreciate that." 80

The public was imagined as a resource, a source of opportunity and potential. A representative of the environmental office in Linköping municipality elaborated:

"Bioenergy is popular, absolutely. Take biogas as an example. More and more customers are buying biogas cars, more and more people are thinking about it. There is a great public acceptance of the technology, and I will also claim - a pride in it." 81

Many actors highlighted an appreciation for the public support, and that their engagement with the public was aimed at maintaining the positive relationship. A senior employee at the traffic department of Linköping municipality gave an example:

79 | Interview with manager Kristine Vold over the telephone, 03.08.2009.

$\mathbf{8 0}$ Interview with manager Lars Knutson in his office, 20.04.2010.

$\mathbf{8 1}$ Interview with environmental office representative Monica Fall in municipal office, 15.04.2010. 
"A few times a year we have these events that we call 'open municipality'. Basically, what happens is that the different offices of the municipality set up stands at town square, and then people can come chat with us about whatever they want. And this has been important, for instance in relation to the biogas projects, to avoid any confusion. I mean, there have been instances when someone has been concerned, but through these events there is a direct line of sorts, and most of the times we are able to cool down the worries." 82

In other words, the respondents still deemed public engagement through conveying positive images of bioenergy important, despite the unproblematic relationship with the public, and maintained that this was best done through two-way communication.

\section{The Strange Norwegian Pig and its Swedish Cousin}

So far, the publics have been imagined as publics in particular in relation to specific bioenergy projects or specific bioenergy products. In Norway, I also discovered an imagined public in general (PiG), primarily imagined by 'experts' - scientists, employees of public agencies, and others more indirectly related to the bioenergy industry. They imagined 'the public' as less tangible and locatable than 'neighbours', 'protesters' or 'customers'. Instead, they imagined an abstract 'Norwegian public' that was opposed to bioenergy because it was incompatible with the idea of 'pure nature', an idea believed to be cherished by the Norwegian public. An employee of a public agency working with bioenergy in Sør-Trøndelag explained how this mentality differed between Sweden and Norway:

"There is a difference in mentality between Sweden and Norway. I mean, hacking away on the forests with the goal of extracting as much as possible biomass would be politically very difficult here. Take this thing with stumps. People wouldn't accept the kinds of large scale interventions into nature that we would need to extract them at any reasonable scale here in Norway. That would be extremely controversial." ${ }^{83}$

$\mathbf{8 2}$ | Interview with senior employee Nils Åkerfeldt in traffic office, 13.04.2010.

83 | Interview with employee Ola Nordmann in his office, 30.09.2009. 
The imagined publics' reaction to bioenergy was a question of bioenergy vs. nature; a battle lost by bioenergy. As in the quote above, many interviewees contrasted the Swedish public to the Norwegian. The Swedish public was seen as an 'ideal public', readily accepting issues seen as problematic in Norway. Thus, the respondents not only imagined a Norwegian PiG, but also a Swedish PiG, more positive towards bioenergy than reported by the Swedes. Another example of the public imagined this way was presented by a Swedish professor working at a Norwegian university:

"It is a sort of strange thing this bioenergy here in Norway. In many ways it has become something negative, something bad. Take the environmental movement, for example. You can almost say that in Sweden, they are pro bioenergy, whereas they are basically against it here in Norway. And if you go to an industry conference here in Norway and look at the average age of the participants, you will not exactly see a young crowd. And this says something about the position of bioenergy with the general public, I think." 84

\section{Imagined Publics - Real Effects}

In the last paragraphs, I have studied how bioenergy in Norway and Sweden have imagined their respective 'publics'. This exercise has illustrated that technology developments are not value-free processes of diffusion, but that the adoption of energy technologies occurs in a complex setting where the agency of multiple actors influences the outcome. 'The public' in its various guises can be a player who can protest, participate and support. The notion of 'imagined publics' illustrates that 'the public' may appear in these processes more indirectly. The public does not actually have to protest a development in order to influence the process, if those trying to implement the technology believe protests to be likely.

In Norway and Sweden, the publics were imagined differently. The Swedish publics were imagined either as ignorant consumers or supportive customers. In Norway, they were imagined as concerned about or opposed to bioenergy based on NIMBY logic, as ignorant non-customers or opponents to bioenergy because it interfered with the idea of 'pure nature'. These ways of imagining the publics resulted in different strategies of

84 | Interview with Professor Pär Vargas over the telephone, 07.10.2009. 
public engagement. Some Swedish players saw public ignorance as a democratic problem and concluded it would be their task to enlighten the public. The Swedes who imagined the public as supporters wanted to preserve the situation and considered the best way to be open two-way dialogue. In Norway, the industry pre-emptively responded to expected NIMBY responses through meetings with perceived stakeholders, mainly to limit the consequences of protests. The ignorant non-consumers were engaged through information campaigns as well as more active attempts to bring them on board as trustworthy users of the technology.

The ways that the publics of bioenergy are imagined in Norway and Sweden also tells us something about the role of bioenergy in Norwegian and Swedish culture. In particular, the notion of bioenergy as invisible to the Swedish publics even though it is the major energy technology in the country stands out as a contrast to the Norwegian situation where bioenergy, a marginal technology, appears controversial. It is likely that this can be attributed to the historical circumstances by which bioenergy was introduced in Sweden, that is through familiar infrastructure for district heating and combined heat and power.

\section{BibLIOGRAPHY}

\section{Primary Sources}

Adresseavisen, 2007-2009 [Sør-Trøndelag, Norway]

Aftenposten, 2007-2009 [Norway]

Aftonbladet, 2007-2009 [Sweden]

Bioenergi, 3-6, 2009 and 1-3, 2010 [Norway]

Bioenergi, 3-6, 2009 and 1-3, 2010 [Sweden]

Interviews, 2009-2010

Svenska Dagbladet, 2007-2009 [Sweden]

Verdens Gang, 2007-2009 [Norway]

Östgöta Correspondenten, 2007-2009 [Östgötaland, Sweden] 


\section{Secondary Sources}

Anshelm, Jonas. Att Ersätta Kärnkraften med Bioenergi - Om en Omstridd Ide i den Offentliga Energipolitiska Debatten I Sverige 1979-2000. Linköping: Tema T, Linköpings Universitet, 2009.

Arntsen, Håkon/Rossing, Sivert. "Fikk 15 Millioner til Strømsparing i Fylket”, in: Trønderavisa, 15.09.2009. http://www.t-a.no/nyheter/article75326.ece, Accessed 01.09.2011.

Barnett, Julie/Burningham, Kate/Walker, Gordon/Cass, Noel. "Imagined Publics and Engagement Around Renewable Energy Technologies in the UK", in: Public Understanding of Science, published online before print on June 30, 2010. http://pus.sagepub.com/content/early/2010/06/21/0963662510365663.abstract, Accessed: 15.12.2011.

Burningham, Kate/Barnett, Julie/Carr, Anna/Clift, Roland/Wehrmeyer, Walter. "Industrial Constructions of Publics and Public Knowledge: A Qualitative Investigation of Practice in the UK Chemicals Industry", in: Public Understanding of Science 16:1 (2008), 23-43.

Devine-Wright, Patrick. "Beyond NIMBYism: Towards and Integrated Framework for Understanding Public Perceptions of Wind Power", in: Wind Energy 8:2 (2005), 125-39.

Dietrich, Heather/Schibeci, Renato. "Beyond Public Perceptions of Gene Technology: Community Participation in Public Policy in Australia”, in: Public Understanding of Science 12:3 (2003), 381-401.

Durant, John. "Participatory Technology Assessment and the Democratic Model of the Public Understanding of Science", in: Science and Public Policy 26:5 (1999), 313-19.

Einsiedel, Edna F./Jelsøe, Erling/Breck, Thomas. "Publics at the Technology Table: The Consensus Conference in Denmark, Canada and Australia", in: Public Understanding of Science 10:1 (2001), 83-98.

Ellis, Rebecca/Waterton, Claire: "Environmental Citizenship in the Making: The Participation of Volunteer Naturalists in UK Biological Recording and Biodiversity Politics", in: Science and Public Policy 31:2 (2004), 95-105.

Energimyndigheten. Energiförsörjingen i Sverige. Stockholm: Energimyndigheten, 2009.

Ertesvåg, Ivar S./Mielnik, Michael: "Exergy Analysis of the Norwegian Society”, in: Energy 25:10 (2000), 957-73. 
European Parliament: "Directive 2009/28/EC of the European Parliament and of the Council of 23 April 2009 on the Promotion of the Use of Energy from Renewable Sources", in: Official Journal of the European Union, 05.06.2009.

Godin, Benoit. "The Linear Model of Innovation. The Historical Construction of an Analytical Framework", in: Science, Technology and Human Values 36:4 (2006), 639-67.

Gross, Alan G. "The Role of Rhetoric in the Public Understanding of Science", in: Public Understanding of Science 3:1 (1994), 3-23.

Habermas, Jürgen. The Structural Transformation of the Public Sphere. Cambridge, MA: MIT Press, 1989.

IEA Energy Statistics: “Electricity/Heat in Norway in 2008”, 2008, http:// iea.org/stats/electricitydata.asp?COUNTRY_CODE=NO, Accessed o1. 09.2011.

Jordal, Anne. “Korleis Utvikle og Lansere Meir Konkurransedyktige Pelletskaminar?", Conference Paper. "Bioenergidagene, 2009”, Rica Nidelven Hotell, 23.11.2009.

Kaijser, Arne/Hedin, Marika, eds. Nordic Energy Systems. Historical Perspectives and Current Issues. Canton, MA: Watson Publishing International, 1995 .

Kall, Ann-Sofie. "Förnyelse med Förhinder” (Unpublished Ph.D. diss., Linköpings Universitet, 2011).

Karlstrøm, Henrik. Den Deregulerte Forbruker. Trondheim: Institutt for Tverrfaglige Kulturstudier, 2010.

Latour, Bruno. Science in Action. Cambridge, MA: Harvard University Press, 1987.

Maranta, Allesandro/Guggenheim, Michael/Gisler, Priska/Pohl, Christian. "The Reality of Experts and the Imagined Lay Person", in: Acta Sociologica 46:2 (2003), 150-65.

Marres, Noortje. “The Issues Deserve More Credit”, in: Social Studies of Science 37:5 (2007), 759-80.

Michael, Mike. "Publics Performing Publics: Of PiGs, PiPs and Politics", in: Public Understanding of Science 18:5 (2009), 617-31.

Midtun, Atle/Gundersen, Mari Hegg/Koefoed, Anne Louise. “Greening of Nordic Electricity Industry: Policy Convergence and Diversity”, in: Energy Q Environment 15:4 (2004), 633-56.

Miller, Steve. "Public Understanding of Science at the Crossroads", in: $\mathrm{Pu}$ blic Understanding of Science 10:1 (2001), 115-20. 
Norman, Dandy. Stakeholder Perceptions of Short-Rotation Forest for Energy. Farnham: Forest Research, 2010.

Norsk Bioenergiforening. Bioenergi i Norge. Oslo: Nobio, 2010.

Olje og Energidepartementet. Strategi for økt Utbygging av Bioenergi. Oslo: OED, 2008. http://www.regjeringen.no/upload/OED/Bioenergistrategien2008w.pdf, Accessed: 04.07.2011.

Rayner, Steve. "Democracy in the Age of Assessment: Reflections on the Roles of Expertise and Democracy in Public-Sector Decision Making”, in: Science and Public Policy 30:3 (2003), 163-70.

Rowe, Gene/Frewer, Lynn J. "A Typology of Public Engagement Mechanisms”, in: Science, Technology and Human Values 30:2 (2005), 251-90.

Skjervak, Geir. “Kvar Blir det av det Store Pelletsløftet i Noreg?”, Conference Paper. "Bioenergidagene, 2009", Rica Nidelven Hotell, 23.11.2009.

Statistisk Sentralbyrå. "Energi", 2011, http://www.ssb.no/energi/, Accessed: 01.09.2011.

Strauss, Anshelm/Corbin, Juliet M. Basics of Qualitative Research: Grounded Theory Procedures and Techniques. Newbury Park, CA: Sage, 1990.

Tjernshaugen, Andreas. "Fossil Interests and Environmental Institutions: The Politics of $\mathrm{CO}_{2}$ Capture and Storage" (Unpublished Ph.D. diss., Universitetet i Oslo, 2009).

Tyholt, Marit/Hestnes, Anne Grete. "Heat Supply to Low-Energy Buildings in District Heating Areas: Analysis of $\mathrm{CO}_{2}$ Emissions and Electricity Supply Security", in: Energy and Buildings 40:2 (2004), 131-39.

Unander, Fridtjof/Ettestøl, Ingunn/Ting, Mike/Schipper, Lee. "Residential Energy Use: An International Perspective on Long-Term Trends in Denmark, Norway and Sweden", in: Energy Policy 34:12 (2008), 13951404 .

Upreti, Bishnu Raj/van der Horst, Dan. "National Renewable Energy Policy and Local Opposition in the UK: The Failed Development of a Biomass Electricity Plant”, in: Biomass and Bioenergy 26:1 (2004), 61-69.

Walker, Gordon. "Renewable Energy and the Public", in: Land Use Policy 12:1 (1995), 49-59.

-. /Cass, Noel. "Carbon Reduction, 'the Public' and Renewable Energy: Engaging with Socio-Technical Configurations”, in: Area 39:4 (2007), 458-69.

-. /Cass, Noel/Burningham, Kate/Barnett, Julie. "Renewable Energy and Sociotechnical Change: Imagined Subjectivities of 'the Public' and Their Implications", in: Environment and Planning 42:4 (2010), 931-47. 
Wynne, Brian. "Reflexing Complexity. Post-genomic Knowledge and Reductionist Returns in Public Science", in: Theory, Culture and Society 22:5 (2005), 67-94. 



\title{
Patterns of Energy Transitions
}

\author{
The Long-Term Role of Energy in the Economic \\ Growth of Europe
}

Silvana Bartoletto

Debates and analyses on the role of energy consumption in economic growth and its environmental impact are of central interest today. Most studies, however, rely on post-1960 data and they usually focus on a single country or region, with a limited perspective on the past. In this article, the topic of energy will be analyzed from the viewpoint of economics, with a long-term historical perspective, over a period of almost 150 years. Several Western European countries will be considered (England, Italy, the Netherlands, Spain and Sweden).

In the transition from the old to a modern economy, energy is of central importance. In recent studies, energy has been recognized as a main determinant of the divergence of Europe from the rest of the world in the $19^{\text {th }}$ century and as the main cause of its success. ${ }^{1}$ Despite the central importance of energy, historians dealt for a long time only sporadically with energy problems. John Nef was the first historian who analyzed energy as the main pillar of the industrial revolution. ${ }^{2}$ After the energy crisis of the 1970s, much empirical research took place on energy, within the context of

1 | Kenneth Pomeranz: The Great Divergence. China, Europe and the Making of the Modern World Economy. Princeton, NJ: Princeton University Press, 2010, $37-$ 47; Paolo Malanima: Pre-Modern European Economy. One Thousand Years (10 ${ }^{\text {th }}$ $19^{\text {th }}$ Centuries). Leiden: Brill, 2009, 49-94.

2 | John Nef: The Rise of the British Coal Industry. London: Routledge \& Sons, 1932 and John Nef: La Naissance de la Civilisation Industrielle et le Monde Contemporain. Paris: Colin, 1954. 
both economic and environmental history. In 1988, Tony Wrigley analyzed the historical transition from organic to mineral resources in the course of industrialization of the British economy, stressing the importance of energy in the industrial revolution. ${ }^{3}$ Vaclav Smil dealt with energy transitions in a long historical perspective. ${ }^{4}$ Joachim Radkau analyzed the connections between forest history and technological developments from the $16^{\text {th }}$ to the $19^{\text {th }}$ century and the energy transition in the wider context of environmental history. ${ }^{5}$

The aim of this article is to examine the role of energy in long-term economic growth. The analysis relies on new data that so far have been mostly used in analyses of long-term trends in energy consumption. ${ }^{6}$ In the first part, I will explain the main changes which have taken place in the energy system over the past two centuries, and in particular the energy transition from traditional to modern energy sources. In the second

3 | Edward Anthony Wrigley: Continuity, Chance and Change: The Character of the Industrial Revolution in England. Cambridge: Cambridge University Press, 1988.

4 | Vaclav Smil: Energy in World History. Boulder, C0: Westview Press, 1994.

5 | Joachim Radkau: Nature and Power. A Global History of the Environment. Cambridge: Cambridge University Press, 2008. On these aspects see also Rolf P. Sieferle: The Subterranean Forest. Energy Systems and the Industrial Revolution. Cambridge: White Horse Press, 2001; Clive Ponting: Storia Verde del Mondo. Torino: Società Editrice Internazionale, 1991.

6 | Long-term trends in energy consumption have been quantified by the Energy, Growth and Pollution Network which was set up in 2003 to link together historians working on the history of energy use and its consequences for the economy and environment in Europe from ca. 1500 to the present. The first stage of the group's work has consisted of developing a common methodology for quantifying energy inputs into the economy and publishing sets of data as the basis for further research, including the first detailed and reliable quantification of consumption of 'traditional' energy carriers in the pre-industrial and modern era for a wide range of countries. This provides a reliable quantitative basis for investigation of the role of energy in economic growth, especially the impact and cause of transition between 'energy carriers'. Other areas of study include the relationship between energy consumption and income levels (energy intensity) in the longterm, $\mathrm{CO}_{2}$ emissions and energy use. For further details see www.histecon.magd. cam.ac.uk/ees/energy_and_growth.html. 
part, I will reconstruct the current structure of energy consumption. The next section will explore the relation between energy, economy and technological change. Energy intensity, i.e. the ratio of energy to output, and its reciprocal, i.e. energy productivity, will be reconstructed and I will try to show the relative importance both of rising consumption and of changes in the productivity of energy in growth of per capita output. In the final part, I will discuss the constraints of the current energy system. The paper's long-term outlook may serve to clarify contemporary trends and provide perspectives on the impact of policy decisions on the energy problem.

\section{The Energy Transition}

Over the past two centuries there has been a massive and continuing increase in the consumption of fossil fuels: first coal and then oil and natural gas. Large-scale use of fossil fuels has led to greatly increased energy consumption. Since 1800 , energy consumption in Western Europe has grown about six fold, in per capita terms (Fig. 1) and 26 fold in total terms.

At the end of the $18^{\text {th }}$ century, the main sources of energy were food, firewood and fodder for working animals. A relatively small contribution came from two other carriers: falling water, utilized by watermills, and wind, exploited by sailboats and mills. Modern growth, from about 1820 to the present, has marked a sharp rise both in the energy sources and in the efficiency of their utilization. This change can be defined as an 'energy transition'. The transition to modern growth is explained as a discontinuity founded on the increase in productive capacity, due to the introduction of new energy carriers (fossil fuels) and engines able to transform energy into mechanical work. Although other deep changes occurred in the use of energy before the modern era ${ }^{7}$, this transition is considered a watershed between past and present.

7 | For instance the use of fire, which represented the most fundamental conquest in the history of energy. 


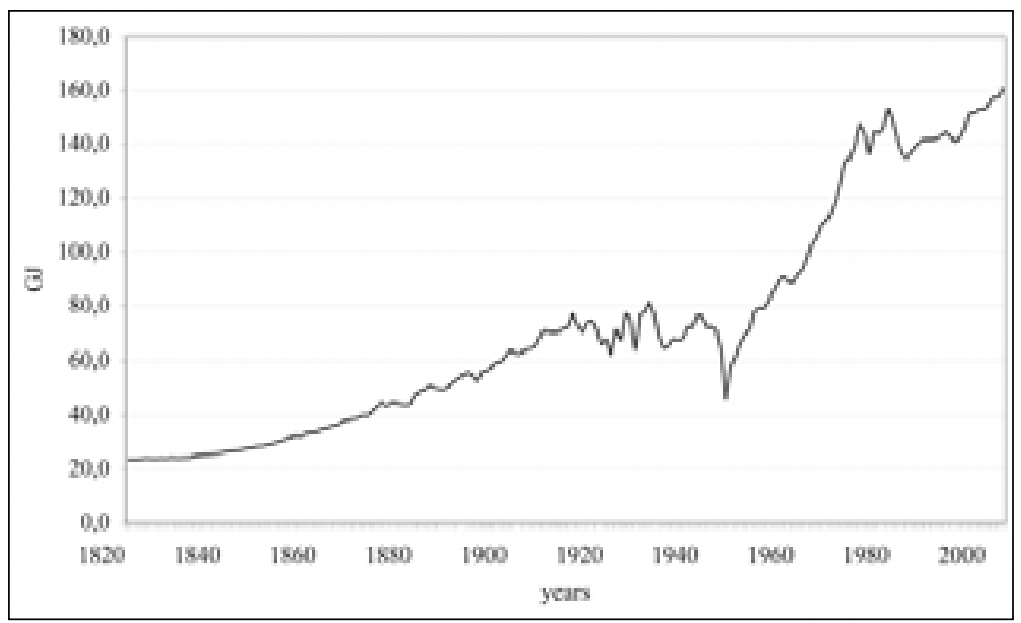

Figure 1: Per Capita Energy Consumption in Europe, 1820-2003 (Gigajoules)

The profound and rapid changes, which took place especially in the second half of the $19^{\text {th }}$ century and the early $20^{\text {th }}$ century, accelerated the process of transition to the new energy system. The strong population growth, worsening climate conditions and the decline of per capita amount of traditional energy sources are the main causes. Especially in the first half of the $19^{\text {th }}$ century, there was a marked acceleration in the rate of population growth. In just 50 years, from 1800 to 1850 , Europe's population expanded from 189 to 288 million. ${ }^{8}$ The balance between the established renewable energy sources on the one hand and the growing population on the other was becoming increasingly difficult to maintain within the prevailing energy system. Wood, the main energy source until the eve of the Industrial Revolution, became increasingly scarce. The energy crisis played an important role for the urbanization process. To feed the growing urban population, the surrounding countryside needed to produce an adequate exchange and agricultural surplus. ${ }^{9}$ However, the

8 | Malanima: Pre-Modern European Economy, 49-94.

9 | With the widespread use of coal instead of wood, cities began to change and grow rapidly, especially since the beginning of the $19^{\text {th }}$ century. For the case of London see Robert C. Allen: The British Industrial Revolution in Global Perspective. Cambridge: Cambridge University Press, 2009; for the case of Naples and other Italian cities see Silvana Bartoletto: "Dalla Legna al Carbon Fossile. I Consumi di 
whole system reached a critical point when population growth exceeded that of agricultural production.

Deforestation for claiming more arable land had already sharply reduced the availability of wood, but it was the acceleration of a series of industrial and commercial activities which brought about a real energy crisis. The food, glass and soap industries consumed enormous quantities of wood, but the highest demand came from shipbuilding and iron production. To understand the magnitude of the energy crisis, it must be kept in mind that wood was the dominant industrial resource as it was used as a fuel and as raw material for instruments, machines, tools and equipment, but also for many end products. It had the same importance as fossil fuels today. ${ }^{10}$ Jeremy Rifkin introduced the concept of 'watershed entropy' to explain the transition from one energy system to another: It was the scarcity of wood that determined its replacement by coal. However, it was not simply the substitution of one energy source with another, but it resulted in a radical change in the way of life. ${ }^{11}$

There are, however, quite a few dissenting opinions on the subject of 'energy crises'. Joachim Radkau for instance, has criticized the thesis that the Industrial Revolution should be seen as a consequence of the catastrophic shortage of wood resources that necessitated the transition to coal, first in England and then in other parts of Europe. ${ }^{12}$ Robert Allen has recently maintained that there was no energy crisis in the $18^{\text {th }}$ century..$^{13}$ Instead, coal was abundant and cheap in Britain and wages were high in

Combustibile a Napoli nel Corso dell'Ottocento", in: Mélanges de l'Ecole Française de Rome 116 (2004), 705-21; Silvana Bartoletto: “L'Energia delle Città. Percorsi di Ricerca, Muovendo dal Caso di Napoli”, in: Gabriella Corona/Simone Neri Serneri, eds. Storia e Ambiente. Città, Risorse e Territori nell'Italia Contemporanea. Roma: Carocci, 2007, 218-33; Silvana Bartoletto: “Energy Consumption in Naples between the $19^{\text {th }}$ and the $20^{\text {th }}$ Centuries", in: Working Papers Department of Economic Studies, University of Naples Parthenope 3, 2009.

10 | Lewis Mumford: Tecnica e Cultura. Milano: il Saggiatore, 1961. Original: Technics and Civilization. New York: Brace \& Company, 1934.

11 | Jeremy Rifkin: Entropia. Milano: Baldini \& Castoldi, 2000.

12 | Radkau: Nature and Power, 195.

13 | Robert C. Allen: “Was There a Timber Crisis in Early Modern Europe?”, in: Simonetta Cavaciocchi, ed. Economia e Energia secc. XIII-XVIII, Istituto Internazionale di Storia Economica. Firenze: Le Monnier, 2003, 469-82. 
comparison to other countries in Europe and Asia. Thus, it was profitable for Britain to replace workers by machines, and that is why the use of coal and steam engines increased rapidly. ${ }^{14}$ Paolo Malanima, by contrast, emphasized the role of energy crises in the energy transition. ${ }^{15}$ He argued that "Allen's conclusion is only correct if we look at pre-modern energy sources in a partial way; that is if we consider firewood and fuels as the only sources of energy, excluding others. However, considering energy in a wider perspective, including, that is, food for humans and animals, we can not but disagree with Allen's view." ${ }^{\prime 6}$

The analysis of the times and ways of the passage from an energy system based on traditional energy sources to another based on fossil fuels reveals considerable differences between countries. The energy transition occurred very rapidly in northern Europe, particularly in England and Wales, where in the mid-1 $9^{\text {th }}$ century fossil fuels represented about $9^{1}$ percent of total consumption while the percentage of traditional energy sources dropped to only 9 percent (Tab. 1). In the Netherlands in 1850 , traditional energy sources represented the largest part of total consumption, but fossil fuels had already gained an important position with 41 percent of the total. The profile of energy balance that emerges from comparative data for Sweden, Italy and Spain is very different. In these three countries in 1850 , the role of fossil fuels was very marginal. In Southern Europe at the beginning of the $20^{\text {th }}$ century, the traditional sources of energy accounted for $70-80$ percent of the energy consumed. ${ }^{17}$

14 | Allen: The British Industrial Revolution; Joseph Zeira: "Workers, Machines and Economic Growth", in: The Quarterly Journal of Economics 113:4 (1998), 1091-117.

15 | Paolo Malanima: "Energy Crisis and Growth 1650-1850: The European Deviation in a Comparative Perspective," in: Journal of Global History 1 (2006), 101-21.

16 | Paolo Malanima: "The Path Towards the Modern Economy. The Role of Energy”, in: Bruno Chiarini, Paolo Malanima, eds. From Malthus' Stagnation to Sustained Growth, Rivista di Politica economica (aprile-giugno 2010/2011), 89.

17 | Silvana Bartoletto/Mar M. Rubio: "Energy Transition and $\mathrm{CO}_{2}$ Emissions in Southern Europe: Italy and Spain (1861-2000)", in: Global Environment 2 (2008), 46-81. 
Table 1: Composition of Energy Consumption in 1850 (\%)

\begin{tabular}{lrrrrr}
\hline & $\begin{array}{r}\text { England \& } \\
\text { Wales }\end{array}$ & Sweden & $\begin{array}{r}\text { Nether- } \\
\text { lands }\end{array}$ & Italy & Spain \\
\hline Muscle & 7 & 25 & 38 & 41 & 50 \\
Firewood & 0 & 73 & 11 & 51 & 46 \\
Wind, water & 2 & $<1$ & 10 & 1 & 2 \\
Fossil fuels & 91 & 2 & 41 & 7 & 2 \\
\hline
\end{tabular}

In Italy and Spain in particular, only on the eve of World War II was the contribution of traditional energy sources reduced to less than half of total consumption. In Italy, the scarcity of fossil fuels resulted in fuel costs 3 to 5 times higher than in competing Western European economies. In order to get a clearer view of these differences we can also consider production quantities. In 1910, the United Kingdom produced about 270,000 tons of coal per year, Germany 150,000, and Italy only 3,000. ${ }^{18}$ The scarcity of energy resources has seriously affected the process of industrialization in Italy, which has followed a different path compared to countries like England where the industrial revolution came about much earlier. In fact, Italy has been specializing in industries with a high intensity of labor, which has been abundantly available, and a low intensity of energy, which has been scarce. This confirms the thesis that the adoption of energy intensive technologies (e.g. the steam engine) was not beneficial everywhere, but depended crucially on the price of production factors. ${ }^{19}$

\section{Energy Consumption}

Currently, energy consumption in Europe is about 1,759 Million Tons of Oil Equivalent (Mtoe) and fossil fuels represent 80 percent of total consumption. Oil is the main energy source, with a percentage of about 33 percent, followed by natural gas (24.6 percent) and coal (18.8 percent). In comparison, the role of renewable energy remains very marginal,

18 | Carlo Bardini: Senza Carbone nell'Età del Vapore. Gli Inizi dell'Industrializzazione Italiana. Milano: B. Mondadori, 1998.

19 | Zeira: “Workers, Machines and Economic Growth”, 1091-117. 
representing only 8 percent of total consumption (Fig. 2). If we examine the evolution of the structure of fossil fuel consumption in a longterm perspective, it is possible to identify three main phases: the first, culminating in the early 1950s, which saw coal in first place in order of importance of fossil fuels; a second phase, during which the consumption of oil exceeds that of coal; a third phase, following the energy crises of the 1970 , which saw the emergence of natural gas as an energy source and the growth of nuclear power, while the use of oil remains predominant, not only in Europe but also worldwide.

Figure 2: Energy Consumption in Europe in 2007 by Energy Sources (percentages)

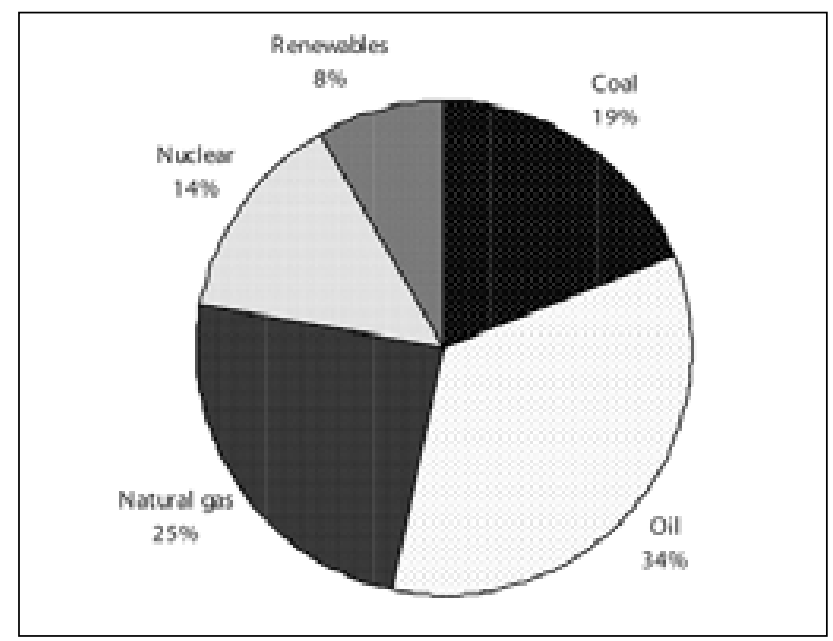

Note: Renewables include hydro (1.51 percent), geothermal (0.32), solar/wind/other (0.61), renewable and waste (5.7).

In the years following the oil crises, one of the main objectives of European energy policy and more generally of industrialized countries has been to shift the supply and demand of energy to the non-oil sources, since they were considered politically more secure. Achieving this goal would entail, on the industrial level, the expansion of nuclear power and increased use of coal in thermoelectric generation besides the intensification of the uses of natural gas not only in industry but especially in residential heating and cooking. 
Final energy consumption in Europe is about 1,224 Mtoe, corresponding to 15 percent of the world's final energy consumption. ${ }^{20}$ Over time, energy consumption in various sectors has changed (Fig. 3).

Figure 3: Final Energy Consumption in Europe in 2007, by Sectors (percentages)

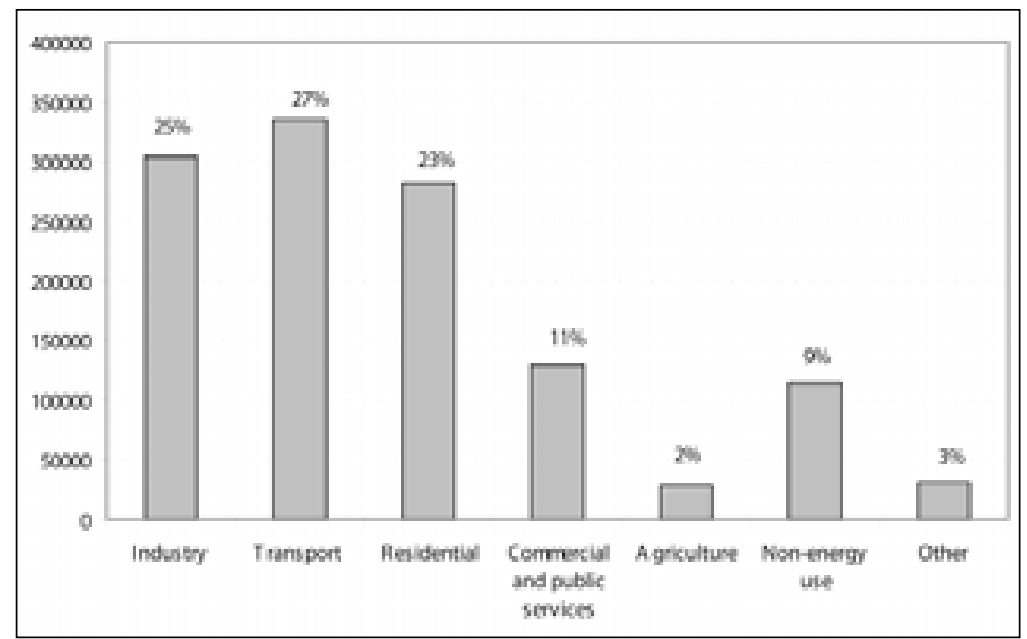

Note: Data refers to EU 27.

The agricultural sector has lost ground to the industry, transport and service sectors, the latter being more intensive in energy use and making almost exclusive use of modern energy sources. The transport sector represents about 27 percent of total final consumption, while industry's share amounts to 25 percent. The tertiary sector, which includes the residential, commercial and public sectors, represents 34 percent of the total. Energy consumption in the industrial sector has decreased since 1973, not only percentage-wise, but also in absolute terms.

20 | Total final energy consumption is the sum of consumption by the different end-use sectors: industry, transport, residential, commercial and public services, agriculture, forestry, fishing. Non energy-use covers those fuels that are used as raw materials in the different sectors and are not consumed as a fuel or transformed into another fuel. 
Typically, over the course of economic development, the output mix changes. In the earlier phases of development, there is a shift away from agriculture towards heavy industry, and in the later stages there is a shift from the more resource-intensive extractive and heavy industrial sectors toward services and lighter manufacturing. Different industries have different energy intensities. This typically results in an increase in energy used per unit of output in the earlier stages of economic development and a reduction in energy used per unit output in later stages.

\section{ENERGY INTENSITY}

To analyze the relation between energy and economic growth it is important to consider two indicators, energy intensity and its reciprocal, energy productivity.

Energy intensity is the ratio of consumed energy to the gross domestic product (GDP) and expresses the energy required to produce one monetary unit of income. In particular, primary energy intensity is calculated as the ratio of gross domestic energy consumption to GDP, while final energy intensity is obtained by dividing the final consumption of energy by GDP.

As a first approximation, a decline over time in energy intensity beyond a certain level of income could be interpreted in terms of increased efficiency of economic systems. What does increase or decrease the ratio of energy intensity is the change in energy consumption (numerator) compared to GDP denominator. If the numerator (energy) increases less than the denominator (GDP), then the energy intensity decreases. The indicator shows to what extent there is a decoupling between gross energy consumption and economic growth, but not the reasons for the trend. It is, in fact, an indicator that enables us to grasp the complexity of the energyeconomy link. To consider it as a measure of the efficiency of an economic system may lead to erroneous conclusions. The change in energy intensity of a given country over time reflects the different nature of the relationship between the growth of energy consumption and the underlying level of economic development. The energy intensity curve shows a trend that varies depending on the state of economic growth. In particular, if the calculation of energy consumption only includes modern energy, the curve grows rapidly during the industrialization phase and reaches its peak at the stage of industrial maturity; afterwards, the energy intensity tends to 
decrease with increasing income, therefore the corresponding curve also decreases thanks to the growth of the services with high added value.

According to an interpretation widespread among economists, energy consumption does not increase in proportion to GDP. The relationship between energy and GDP (energy intensity) shows a pattern which resembles an inverted U-shaped curve or a curve that grows in the early stages of industrialization and subsequently declines during the postindustrial period. This theory was supported in an influential article of Jose Goldenberg and Amulya Reddy, published in the Scientific American in $1990 .{ }^{21}$ This study, however, did not take into account traditional energy sources that were consumed before the introduction of fossil fuels. More recent studies, conducted with reference to countries such as Italy, Spain, Sweden and the Netherlands, have shown that in the longer term, energy intensity tends to decrease and the respective curve does not show an inverted U-shape if the calculation also includes traditional energies (Fig. $4) .^{22}$

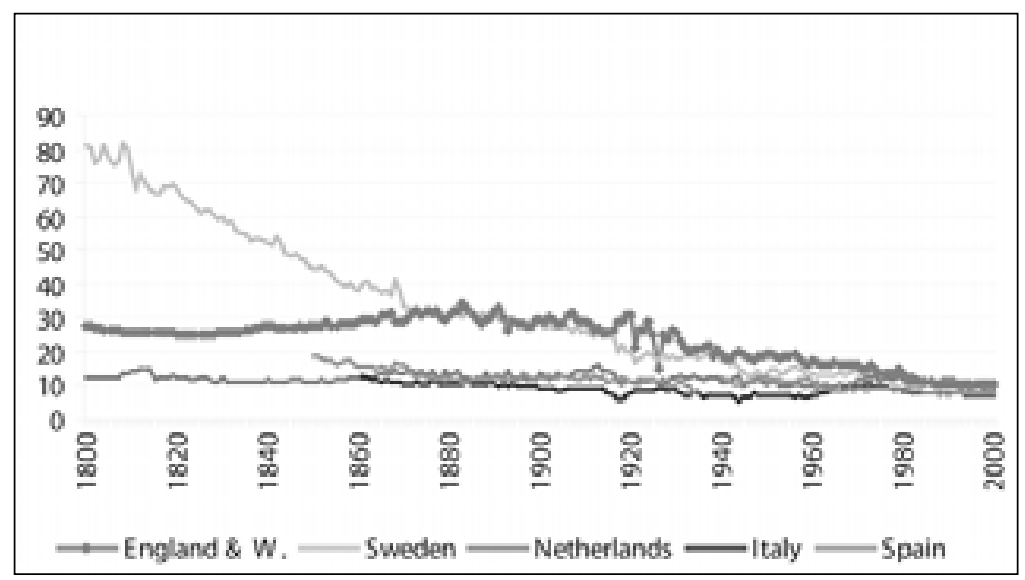

Figure 4: Energy Intensity in Europe, 1800-2000 (Megajoules/1990 \$ ppp)

21 | Jose Goldenberg/Amulya Reddy: “Energy for the Developing World”, in: Scientific American 263:3 (1990), 111-18.

22 | Ben Gales/Astrid Kander/Paolo Malanima/Mar M. Rubio: "North versus South. Energy Transition and Energy Intensity in Europe over 200 Years", in: European Review of Economic History 11 (2007), 219-51. 
For England and Wales, the estimated trends diverge widely prior to 1850 , depending on which estimates for GDP have been chosen. Energy intensity rose steadily peaking in 1883 . After 1883 , with a few exceptions, energy intensity showed a steadily declining level until the 1990s, with particularly rapid drops in periods when the traditional manufacturing industry was struggling: the early 1930 s and $1973-88 .^{23}$

There is no consensus on the causes of the downward trend in energy intensity. For Italy, Spain, Sweden and the Netherlands, more recent studies have shown that the growth of services in economic structure determines only about 15 percent of the total reduction in energy intensity. Technological change has played a more important role in this decline than services' growth. Thanks to mainly technological progress, further economic growth with decreasing energy intensity becomes possible. Not only technical changes but also many other variables have affected progress in energy intensity trends, e.g. structural changes, energy prices and the quality of energy. Since technical and structural changes occur simultaneously in the economy, it is hard to determine which of the two variables is responsible for changes in energy intensity. The use of new energy sources stimulated and, at the same time, came about as a result of the exploitation of new technologies which in turn, had an impact on productivity, the prices of commodities and their consumption.

Production can be boosted either by means of a quantitative increase of production factors or by increasing overall productivity. Investment and capital increases are one of the most important growth factors in industrialized countries. However, as far as energy intensity is concerned, the quality of production factors is far more important than their quantity. In the industrial sector, for example, microelectronics has facilitated automation and coordination of production systems, and this has affected both labor demand and energy consumption. Microelectronics has also had a decisive impact on other sectors of the economy. ${ }^{24}$ Automobiles, TV-sets,

23 | Paul Warde: Energy Consumption in England and Wales. Naples: Consiglio Nazionale delle Ricerche, Istituto di Studi sulle Società del Mediterraneo, 2007.

24 | I refer especially to the semiconductor, which is considered the most spectacular macroinvention of the $20^{\text {th }}$ century (Joel Mokyr: The Gifts of Athena. Princeton, NJ: Princeton University Press, 2002, 112). For a deeper analysis of the role of technological and scientific knowledge in the economic development during the past two centuries, see also Mokyr's The Lever of Riches: Technological 
radios, and household appliances all rely on electronic circuitry, and this affects energy consumption. Going back in time, in the industrial sector, assembly-line production was important for specialization and economies of scale, and electricity played a decisive role in raising productivity in assembly lines since they employed electric motors.

Energy prices have a crucial impact on the development of energy intensity. When prices rise, energy intensity tends to decrease for a more efficient use of energy thanks either to increasingly efficient energy utilization or to a structural shift. In fact, the reduction in energy intensity means energy savings per unit of output and it is caused, first of all, by the desire to save money in the production process in order to maintain or increase profits, as demonstrated by past experiences. During the $1950 \mathrm{OS}$ and Gos, when energy was plentiful and cheap, energy intensity was high.

Following the oil crises of the 1970s and the large increase in oil prices, total world energy intensity has decreased. From 0.32 (toe/thousand 2000 U.S. \$ ppp) in $1971^{25}$, the intensity dropped to 0.20 in 2007 (Fig. 5).

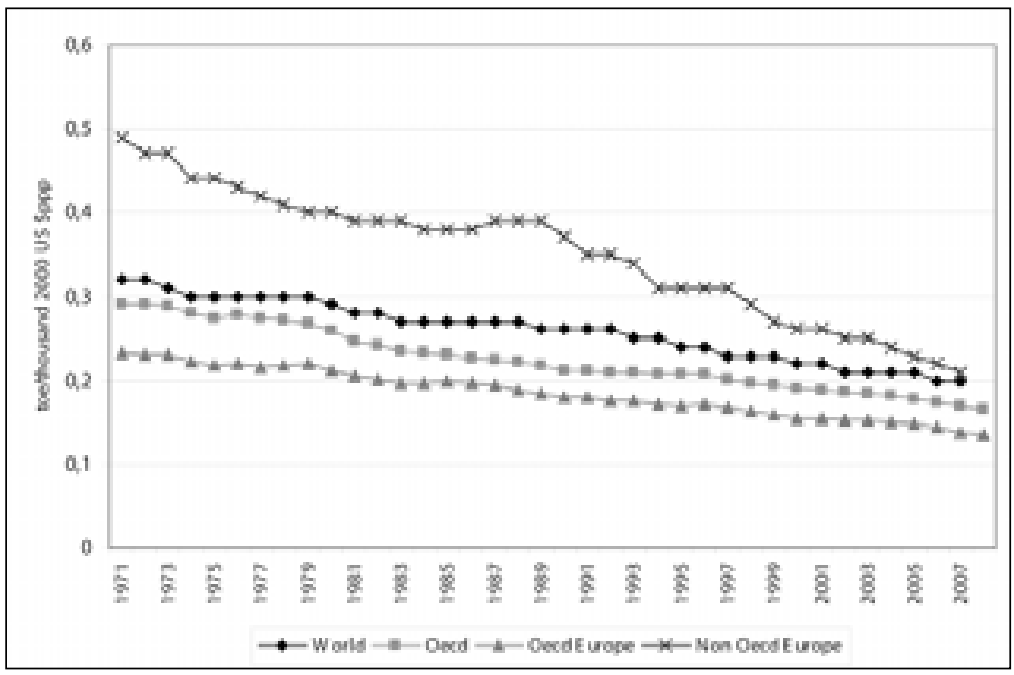

Figure 5: Energy Intensity Trends in Europe (1971-2008)

Creativity and Economic Progress. New York: Oxford University Press, 1990 and Leggere la Rivoluzione Industriale. Bologna: il Mulino, 1997.

25 | Energy consumption is expressed in tons oil equivalent (toe), while GDP is expressed in $2000 \$$ at purchasing power parity (ppp). 
As for European countries, there are very stark differences between those that are members of OECD and those that are not. Non-OECD countries have much higher energy intensity, although over the last forty years, the decline was much sharper than that of other European countries.

However, the energy intensity indicator alone is not sufficient to understand the complexity of the link between energy, economy and environment. In particular, from an environmental point of view, everything depends on the amount of energy consumed and the mix of fuels used. Even if two countries have the same energy intensity or show the same trends during a certain time period, there may be significant environmental differences between them. In other words, even without a significant reduction in energy intensity, the environmental impact of energy consumption can be reduced, for example as a result of a change in fuel mix. Emblematic are the cases of China and the United States which, despite the reduction in their energy intensities, remain the two biggest polluters of the earth.

\section{Energy Productivity}

There is no direct link between the energy converted in the production of goods and their economic value. Very small amounts of energy conversion can create large value and vice versa. The size of energy flow is not necessarily correlated with the value we give to a particular economic output. At the same time, there is a difference between the thermodynamic efficiency of the physical conversion of energy from one form to another and the economic efficiency in turning energy into value. Energy carriers, whether primary or secondary, are converted into energy services, which are heat, motion and light. In line with the second law of thermodynamics, all these conversions of energy from one form to another entail losses. Thermodynamic efficiency $(\eta)$ can be expressed through the ratio (and then multiplied by 100)

$$
\eta=\frac{E_{u}}{E_{i}}
$$

where Eu is useful energy (or energy services) and Ei is the input of energy in the form of a primary or secondary source. 
The measure of economic and not only thermodynamic efficiency is called energy productivity

$$
\pi=\frac{Y}{E}
$$

where $\mathrm{Y}$ is output in monetary terms and $\mathrm{Ei}$ is the raw input of energy (and not energy services) into the economic flow. As far as we know, increases in thermodynamic efficiency imply increases in energy productivity. For example, the transition from biological engines to mechanical engines, which is the main recent change in the energy system, implied both a rise in energy yield or efficiency and energy productivity. However, while the first formula deals with the mere technical structure of an engine or a series of engines, the second is more comprehensive and includes, at the same time, both technical and organizational and institutional changes. Productivity of energy is not only influenced by the technical capacity of conversion, but also by other variables, such as the specialization of economy in particular sectors and sub-sectors. If parts of the economy that are more energyefficient than others grow faster and provide a greater share of national income, the energy productivity of the economy will increase even though technical knowledge has not changed. Many variables can influence energy productivity such as climate and the structure of the economy. In a northern country, specialized in heavy industry, energy productivity can be much lower than in a southern region specialized in light industry.

Also, the level of gross output and changes in the institutions that rule the economy, society and the performance of economic variables all influence energy productivity. 
Table 2: Energy Productivity, Energy Consumption and Population in 12 Western European Countries (1820-2001)

\begin{tabular}{cccc}
\hline & Energy productivity & Energy consumption & Population \\
\hline 1820 & $(\mathrm{GDP} / \mathrm{GJ})$ & $(\mathrm{PJ})$ & (million) \\
1850 & 52.71 & 2,707 & 115 \\
1870 & 56.48 & 4,222 & 144 \\
1890 & 52.57 & 6,450 & 162 \\
1913 & 48.24 & 10,259 & 187 \\
1921 & 47.72 & 17,617 & 228 \\
1931 & 53.27 & 13,832 & 222 \\
1941 & 58.27 & 16,467 & 237 \\
1951 & 69.80 & 17,941 & 248 \\
1961 & 67.67 & 20,107 & 258 \\
1971 & 84.75 & 25,794 & 276 \\
1981 & 83.29 & 40,107 & 298 \\
1991 & 99.60 & 43,133 & 306 \\
2001 & 117.76 & 45,503 & 314 \\
\hline
\end{tabular}

Note: This table includes 12 Western European countries: Austria, Belgium, Denmark, Finland, France, Germany, Italy, Netherlands, Norway, Sweden, Switzerland and United Kingdom.

From the analysis of energy productivity in Europe (Tab. 2), it may be noted that the introduction of modern energy carriers and machines implied a rise in energy productivity only from the end of the $19^{\text {th }}$ century onwards. ${ }^{26}$ Replacing the work of humans (or draught animals) by that of machines can bring about either an increase or a reduction in energy productivity,

26 | For data on energy productivity in Western European countries see Silvana Bartoletto: “Energy and Economic Growth in Europe. The Last Two Centuries", in: Bruno Chiarini/Paolo Malanima, eds.: From Malthus' Stagnation to Sustained Growth, Rivista di Politica economica (aprile-giugno 2010/2011), 57-75; Angus Maddison: The World Economy. Historical Statistics. Paris: OECD, 2002. 
depending on the efficiency of machines versus muscle power. In the early $19^{\text {th }}$ century, machines were less energy-efficient than human beings and animals; only gradually did the machines' energy-efficiency surpass that of living beings. As long as machines remained less efficient, the increase of the machine-work ratio resulted in a reduction in energy productivity. And conversely, ever since machines became more efficient than living beings, every increase in the ratio of machine work to human or animal muscle power has determined an increase in overall energy productivity.

In the case of Western Europe, energy productivity fell from 52.71 (GDP/ GJ) in 1820 to 47.72 (GDP/GJ) in 1913 (Tab. 2). During this period, the GDP increase depended totally on the growth of energy consumption. From the First World War to the Second World War, there was an important increase in energy productivity. Improvements in the efficiency of the techniques of energy exploitation played a very important role. Otherwise, in the 1950 s and 6os, economic growth was sustained not only by an increase in energy productivity, but also by a strong increase of energy consumption. Oil was the main energy source and since it was abundant and cheap, no particular attention was paid to energy saving methods. After the 1970s oil crises, the productivity of energy played a more important role than energy consumption.

In order to better understand the relative importance of the input of energy and the efficiency of its exploitation, we can carry out a decomposition analysis of per capita GDP. Per capita GDP (Y/P) is, in fact, the product of energy consumption per capita $(\mathrm{E} / \mathrm{P})$ multiplied by the productivity of energy (Y/E):

\section{$\frac{Y}{P}=\frac{E}{P} \cdot \frac{Y}{E}$}

If we assume:

$\mathrm{y}$ as the rate of growth of $\mathrm{Y} / \mathrm{P}$;

e as the rate of growth of $\mathrm{E} / \mathrm{P}$; and

$\pi$ as the rate of growth of $\mathrm{Y} / \mathrm{E}$;

we can specify the relative importance of e and $\pi$ in the growth of $y$, during the period concerned; that is the years from 1820-30 until 2000. Thus: 
Table 3: Rates of Growth of Per Capita GDP (y), Per Capita Energy Consumption (e) and Productivity of Energy ( $\pi$ ) 1820-2000 in Western Europe

\begin{tabular}{lccc}
\hline & $y$ & $e$ & $\pi$ \\
\hline $1820-1850$ & 0.42 & 0.32 & 0.10 \\
$1850-1870$ & 0.50 & 0.65 & -0.16 \\
$1870-1890$ & 0.51 & 0.70 & -0.19 \\
$1890-1913$ & 0.63 & 0.65 & -0.02 \\
$1913-1921$ & -0.58 & -1.18 & 0.60 \\
$1921-1931$ & 0.86 & 0.47 & 0.39 \\
$1931-1941$ & 0.96 & 0.18 & 0.78 \\
$1941-1951$ & 0.19 & 0.32 & -0.13 \\
$1951-1961$ & 1.76 & 0.78 & 0.98 \\
$1961-1971$ & 1.51 & 1.59 & -0.08 \\
$1971-1981$ & 0.98 & 0.20 & 0.78 \\
$1981-1991$ & 0.84 & 0.11 & 0.73 \\
$1991-2001$ & 0.70 & 0.37 & 0.33 \\
\hline
\end{tabular}

From 1820 until the First World War, a remarkable decline took place in energy productivity, especially during the period $1850-1890$ (Tab. 3). The input of energy contributed more than the productivity of energy to the growth of GDP. From 1913, both the contribution of rising consumption and its more efficient use determined a growth in GDP, with some differences. The rate of growth of energy productivity was much higher than the rate of growth of per capita energy consumption during the periods 1913-1921, 1931-1941 and 1971-1991, reaching a maximum during the decade 1951-1961. During the 1960s, energy productivity slowly diminished because energy, especially oil, was both abundant and cheap and energy use was less efficient. After the severe oil crises of the 1970s, the higher price of energy encouraged more efficient exploitation and a decline of energy consumption in the industrial sector. Compared to other continents, Europe today has the highest energy productivity and the lowest energy intensity. Because of the high dependence on fossil fuels, the reserves of which are finite, and the high price of energy, Europe's energy policies are 
aimed at increasing the ratio of renewable energy and improving energy efficiency.

\section{The Constraints of the Current Energy System}

Currently, world total primary energy consumption is 12,267 Mtoe and it has doubled since the beginning of the 1970s. ${ }^{27}$ The increase has been determined by several causes. Not only population growth, but also the increase of final energy consumption played a very important role. In 1973, about 60 percent of total final energy consumption was concentrated in OECD countries. During the following years, this percentage declined and in 2008 final energy consumption in OECD countries was 43.8 percent. In contrast, in China and Asia, total final energy consumption has doubled. It also increased significantly in the former Soviet Union and in the Middle East. From 1973 to 2008 , the percentage of oil consumption on total final energy consumption in the world declined from 48.1 to 41.6 percent. Coal is employed mainly in industry (78.5 percent), oil is consumed mostly for transport (61.4), while gas is used mainly in the tertiary sectors but also plays an important role in industry (35.1).

The world energy balance is changing due to the enormous growth in the energy consumption of China and India, whose role in international trade of fossil fuels continues to increase. The strong economic growth of these two countries in recent years has resulted in a significant increase in their demand for energy, which is increasingly met through imports. The energy resources of China, especially coal, are substantial, but not enough to completely satisfy its growing needs. In the first half of 2007 , China became a net importer of coal. ${ }^{28}$ In India, coal remains the main fuel. It is expected that over the next 20 years India will even triple its coal consumption. ${ }^{29}$ The growing worldwide demand for energy has led

27 | International Energy Agency (IEA): Key World Energy Statistics 2010. Paris: OECD/IEA, 2010. Data on total world energy consumption refers to 2008.

28 | On the Chinese energy transition pattern see also Vaclav Smil: Energy Transitions - History, Requirements, Prospects. Santa Barbara, CA: Praeger, 2010, 95-99.

29 I International Energy Agency (IEA): World Energy Outlook 2007. Paris: OECD/IEA, 2007, 3. 
to considerable concern about the security of energy supplies because of growing competition between countries for supplies and the increasing dependence of the consuming countries on few producing countries, which are often politically unstable. The concentration of oil and gas reserves in a small group of countries, particularly in Russia and the countries of the Middle East members of OPEC, determines their market dominance. The greater the increase in the demand for oil and gas in these regions, the greater the likelihood of rising prices. In Europe, the problem of secure energy supplies has become an issue as a result of increasing energy dependence. ${ }^{30}$ Since 1990 , the energy dependence of Europe has grown from 45 to 55 percent (Fig. 7).

Figure 6: Energy Dependency in Europe, 1990-2007 (Mtoe)

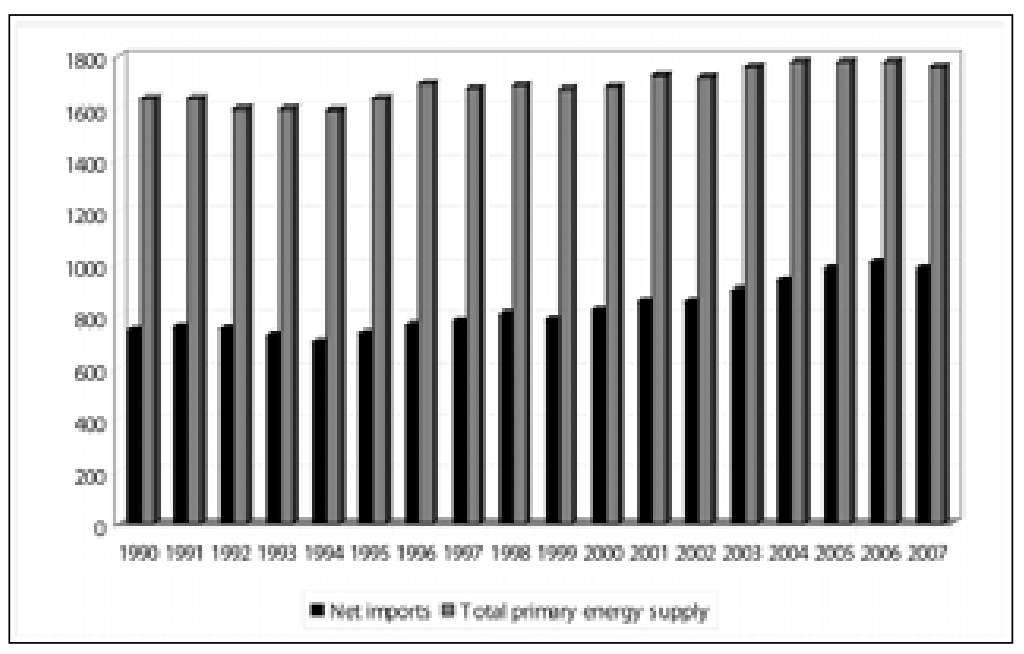

From the mid $18^{\text {th }}$ century until the first half of the $20^{\text {th }}$ century, coal was the main energy source on which Europe built its industrial power, largely under conditions of energy autonomy. With the outset of the age of oil and later of natural gas, imports of energy sources have become inevitable and are steadily growing. Only after the energy crises of the 1970 s did the

30 | Energy dependency is calculated as net imports (imports-exports) divided by total energy consumption. 
problem of energy dependence and security of energy supply in Europe capture the attention of the economic policy debate.

Italy is certainly one of the countries with the highest levels of energy dependency, as about 90 percent of its energy demand is met by fossil fuel imports, notably through oil and natural gas. Following the oil crises of the 1970s, natural gas consumption has greatly increased in Italy, currently representing 39 percent of total demand. However, oil remains the main source of energy, because it represents 42 percent of total demand. ${ }^{31}$ In Italy, energy policies have failed to reduce the degree of dependence. The diversification of the energy sources supply has been only marginal, replacing imported oil with imported natural gas. Not only Italy, but also other European countries have invested in natural gas. In fact, the greater part of new thermoelectric capacity installed in Europe over the past ten years is fuelled by gas, which currently provides about a quarter of Europe's electricity production, compared to 7 percent in the early 1980 s. ${ }^{32}$ However, having focused so strongly on natural gas, for the European Union this has meant a greater dependence on imports.

After the oil crises, several European countries have invested heavily in nuclear power. In France, for example, nuclear power is the main energy source, with a share of 43 percent of total demand. In Sweden, nuclear power represents 33 percent of total consumption.

The recent disaster at the Fukushima nuclear plant has reignited the debate on the use of nuclear power, leading some countries to abandon it permanently. In Germany, where nuclear power currently accounts for 22 percent of the electricity needs of the country, the government has decided to shut down all reactors by 2020 , following strong protests against the use of atomic energy. In Italy in 2008, the Berlusconi government had announced it would resume its nuclear program through the construction of four third-generation nuclear power plants, with the aim of covering at least 10 percent of Italy's energy demand. But, after the Fukushima disaster, following the referendum in June of 2011, Italy has once again abandoned the project to produce electricity by splitting the atom. Risks associated with the process of nuclear power generation are very serious, as amply demonstrated by the disasters of Fukushima (2011) and Chernobyl in the

31 International Energy Agency (IEA): Energy Balances of OECD Countries, 2009 edition. Paris: OECD/IEA, 2009.

32 | Alberto Clô: Il Rebus Energetico. Bologna: il Mulino, 2008, 45-82. 
Ukraine (1986). Another serious problem is how to deal with radioactive waste from nuclear power plants. The approximately 440 existing nuclear reactors in 31 countries produce thousands of tons of waste annually. ${ }^{33}$ In addition, there is the risk that certain countries that have nuclear technology may use it to develop nuclear weapons.

Thus, in seeking a more secure and reliable energy system, increased deployment of renewable energy sources is essential. The heated political and economic debate on unsustainable present-day energy consumption encourages the development of a more secure and sustainable energy consumption model. Great hopes are placed especially on wind, hydroelectric, and solar energy. The capital intensity of renewable energy is greater than that of fossil fuels and therefore the investment required to create additional generating capacity from renewable sources is very high. Thus, energy policies should focus on the goal of increasing the importance of the combination of different renewable energy sources, as approved in the package "Climate Action and Renewable Energy", adopted by the European Council on April 6, 2009. Here, member states have agreed to reduce emissions of greenhouse gases by 20 percent below 1990 levels by 2020 and to increase energy efficiency by 20 percent, reaching a quota of 20 percent renewable energy for end use by 2020 . Of course, the answers to the problem vary from country to country. Oil is the main source of energy in the world and will remain so for a long time, even under the most optimistic assumptions about growth rates and diffusion of alternative technologies. A quantitatively significant transition from fossil fuels to new renewable sources cannot be seen only in the long term perspective. A market penetration of renewables will require strong public support for a rapid development of technologies to reduce costs of producing and using renewable energy.

\section{Concluding Remarks}

In recent years, the emphasis on energy within the transition from the old to the modern economy has received new attention. During the last two centuries, the energy system has changed, shifting from renewables to non-renewable energy sources. Currently, fossil fuels represent 80 percent

33 | Clô: /l Rebus Energetico, 97-109. 
of total consumption in Europe and in the world. Following large-scale use of fossil fuels, energy consumption grew exceptionally strongly, especially after the Second World War.

The transition from traditional renewable energy sources to fossil fuels was a slow process because the two sources have coexisted for a long time. We could say that the present energy balance represents the result of a long and slow evolution of the energy system and of technologies used to transform energy into work. In Europe, the use of coal during the $17^{\text {th }}$ century and much of the $18^{\text {th }}$ century remained modest and devoid of real importance in the economy. An exception is northern England and the Netherlands, whose economic success, especially since the $17^{\text {th }}$ century, was largely dependent on the exploitation of new energy sources. Until the early decades of the $20^{\text {th }}$ century, much of Western Europe still depended significantly on traditional energy sources. Working animals continued to play an important role in agriculture and transport. Wood was still widely used for heating and cooking. Not only that, but in vast regions, wood, water and wind represented the major sources of energy in industry even in the late $19^{\text {th }}$ century. The advantages of energy-intensive manufacturing and transport technologies are immediately visible in the trend of energy productivity $(\mathrm{Y} / \mathrm{E})$, which is the reciprocal of energy intensity formula $(\mathrm{E} / \mathrm{Y})$. Analyzing the trend of energy productivity in Europe, we can identify four periods during which the energy-growth relationship has presented different characteristics. A first phase, which covered the time span from 1820 to the end of the $19^{\text {th }}$ century, is characterized by a reduction of energy productivity. A second phase lasted from the beginning of the $20^{\text {th }}$ century until the Second World War. In this period, the improvements in the efficiency of techniques of energy utilization played a more important role for economic growth than the amount of energy used. In a third phase, from post-World War II until the energy crises of the 1970s, the output growth was sustained mainly by the increase in the availability of energy sources and not by increases in the thermodynamic efficiency of techniques used. During the fourth phase following the oil crises, improvements in the efficiency of energy exploitation played and continue to play an important role in economic growth. Despite growing awareness of European dependency on finite fossil energy sources and the growth of $\mathrm{CO}_{2}$ emissions, the consumption of renewable energy sources remains marginal. If in the past century, the transition to fossil fuels was an important condition to overcome the limits to growth, today we risk 
a new 'trap' without a new transition path towards a new energy system where renewable energy will play an important role.

\section{UNITS OF MeAsure}

Kilocalorie (Kcal): 4,1868 Joule

Joule (J) or kilojoule: $0,239 \mathrm{kcal}$

Gigajoule (Gj): 1 million of kilojoule

Petajoule $(\mathrm{Pj})$ : 1 million of gigajoule

Tons oil equivalent (toe): 10 million of kcal

\section{References}

Allen, Robert C. "Was There a Timber Crisis in Early Modern Europe?”, in: Simonetta Cavaciocchi, ed. Economia e Energia secc. XIII-XVIII, Istituto Internazionale di Storia Economica. Firenze: Le Monnier, 2003, 469-82.

-. The British Industrial Revolution in Global Perspective. Cambridge: Cambridge University Press, 2009.

Bardini, Carlo. Senza Carbone nell'Età del Vapore. Gli Inizi dell'Industrializzazione Italiana. Milano: B. Mondadori, 1998.

Bartoletto, Silvana. "Dalla Legna al Carbon fossile. I Consumi di Combustibile a Napoli nel Corso dell'Ottocento", in: Mélanges de l'Ecole Française de Rome 116 (2004), 705-21.

* —. "I Combustibili Fossili in Italia dal 1870 a Oggi”, in: Storia Economica 2 (2005), 281-327.

—. "L'Energia delle Città. Percorsi di Ricerca, Muovendo dal Caso di Napoli”, in: Gabriella Corona/Simone Neri Serneri, eds. Storia e Ambiente. Città, Risorse e Territori nell'Italia Contemporanea. Roma: Carocci, 2007, 218-33.

- . "Energy Consumption in Naples between the $19^{\text {th }}$ and the $20^{\text {th }}$ Centuries”, in: Working Papers Department of Economic Studies, University of Naples Parthenope 3, 2009.

* —. “L'Energia. L'Intensità Energetica nei Paesi del Mediterraneo” in: Malanima Paolo, ed. Rapporto sulle Economie del Mediterraneo. Edizione 2010. Bologna: il Mulino, 2010, 213-37.

* _. "Energy and Economic Growth in Europe. The Last Two Centuries", in: Bruno Chiarini/Paolo Malanima, eds. From Malthus' Stagnation to 
Sustained Growth, Rivista di Politica economica (aprile-giugno 2010/2011), 57-75.

* —. "Energia e Ambiente in Europa (1800-2010)", in: Rivista di Studi sulla sostenibilità 2 (2011), 59-78.

-./Rubio Mar M. "Energy Transition and $\mathrm{CO}_{2}$ Emissions in Southern Europe: Italy and Spain (1861-2000)", in: Global Environment 2 (2008), 46-81.

Clô, Alberto. Il Rebus Energetico. Bologna: il Mulino, 2008.

Gales, Ben/Kander, Astrid/Malanima, Paolo/Rubio, Mar M. "North versus South. Energy Transition and Energy Intensity in Europe over 200 Years", in: European Review of Economic History 11 (2007), 219-51.

Goldenberg, Jose/Reddy, Amulya. "Energy for the Developing World”, in: Scientific American 263:3 (1990), 111-18.

International Energy Agency (IEA). World Energy Outlook 2007. Paris: OECD/IEA, 2007.

-. Energy Balances of OECD Countries. 2009 edition. Paris: OECD/IEA, 2009.

—. Key World Energy Statistics 2010. Paris: OECD/IEA, 2010.

* Kander, Astrid. Economic Growth, Energy Consumption and $\mathrm{CO}_{2}$ Emissions in Sweden 1800-2000. Stockholm: Almqvist \& Wicksell International, 2002.

* Maddison, Angus. The World Economy. Historical Statistics. Paris: OECD, 2003 .

* - Contours of the World Economy, 1-2030 AD. Essays in Macro-Economic History. Oxford: University Press, 2008.

* Malanima, Paolo. Energy Consumption in Italy in the $19^{\text {th }}$ and $20^{\text {th }}$ Centuries. Napoli: Consiglio Nazionale delle Ricerche, 2006.

-. "Energy Crisis and Growth 1650-1850: The European Deviation in a Comparative Perspective”, in: Journal of Global History 1 (2006), 101-21.

-. Pre-Modern European Economy. One Thousand Years $\left(10^{\text {th }}-19^{\text {th }}\right.$ Centuries). Leiden: Brill, 2009 .

-. "The Path Towards the Modern Economy", in: Bruno Chiarini/Paolo Malanima, eds. From Malthus' Stagnation to Sustained Growth, Rivista di Politica economica (aprile-giugno 2010/2011), 77-105.

Mokyr, Joel. The Lever of Riches: Technological Creativity and Economic Progress. New York: Oxford University Press, 1990.

—. Leggere la Rivoluzione Industriale. Bologna: il Mulino, 1997.

-. The Gifts of Athena. Princeton, NJ: Princeton University Press, 2002. 
Mumford, Lewis. Tecnica e Cultura. Milano: il Saggiatore, 1961. Original: Technics and Civilization. New York: Brace \& Company, 1934.

Nef, John. The Rise of the British Coal Industry. London: Routledge \& Sons, 1932.

-. La Naissance de la Civilisation Industrielle et le Monde Contemporain. Paris: Colin, 1954 .

Pomeranz, Kenneth. The Great Divergence. China, Europe and the Making of the Modern World Economy. Princeton, NJ: Princeton University Press, 2010.

Ponting, Clive. Storia Verde del Mondo. Torino: Società Editrice Internazionale, 1991.

Radkau, Joachim. Nature and Power. A Global History of the Environment. Cambridge: Cambridge University Press, 2008.

Rifkin, Jeremy. Entropia. Milano: Baldini \& Castoldi, 2000.

Sieferle, Rolf P. The Subterranean Forest. Energy Systems and the Industrial Revolution. Cambridge: White Horse Press, 2001.

Smil, Vaclav. Energy in World History. Boulder, CO: Westview Press, 1994.

-. Energy Transitions. History, Requirements, Prospects. Santa Barbara, CA: Praeger, 2010.

Warde, Paul. Energy Consumption in England and Wales. Naples: Consiglio Nazionale delle Ricerche, Istituto di Studi sulle società del Mediterraneo, 2007.

Wrigley, Edward Anthony. Continuity, Chance and Change: The Character of the Industrial Revolution in England. Cambridge: Cambridge University Press, 1988.

Zeira, Joseph. "Workers, Machines and Economic Growth", in: The Quarterly Journal of Economics 113:4 (1998), 1091-117.

* Data used in the figures and tables have been taken from these titles. 


\section{Authors}

Karl-Michael Brunner (Ph.D.) is Associate Professor at the Institute for Sociology and Social Reaearch at Vienna University of Economics and Business. His research interests are environmental sociology, sustainable consumption, lifestyles, food and energy as well as poverty.

Silvana Bartoletto (Ph.D.) is currently lecturer (ricercatore) and Assistant Professor of Economic History at University of Naples Parthenope, Department of Economic Studies "S. Vinci". She works on the economic and environmental history of Italy and Europe. Her interests focus upon the long-term history of energy use and its relationship with economic development and environmental change. She is a member of "The Energy, Growth and Pollution Network", which links together historians working on the history of energy use. She is currently affiliated with the Italian National Research Council, Institute for Studies on Mediterranean Societies, where she studies energy production and consumption in Mediterranean countries from the 1970 os onwards.

Yves Bouvier (Ph.D.) is Assistant Professor of Contemporary History at the University of Savoie (Chambéry, France). From 2003 to 2011, he has served as scientific secretary of the Committee for the History of Electricity at the EDF Foundation. His research fields are the history of energy and the history of communication in France (business history and public policies history).

Anja Christanell (Ph.D.) is senior researcher and managing director of the Austrian Institute for Sustainable Development in Vienna. Her research 
interests are sustainable consumption, fuel poverty, local knowledge systems, youth and sustainability.

Helena Ekerholm is a Ph.D. candidate at the Department of Historical, Philosophical and Religious Studies at Umeå University in Sweden. Her doctoral thesis deals with alternative automobile fuels in Sweden during the interwar years and World War II. Her research is part of the Swedish Research Council Formas funded research programme "Fuel of the Future? A Research Programme on the Science, Technology and Selling of Biofuels in Sweden" under Christer Nordlund, Professor in History of Science and Ideas at Umeå University.

Sophie Gerber (MMag. phil.) is a Ph.D. candidate and research associate at the Department of the History of Technology at the Technical University of Munich, focusing on the history of energy consumption. She studied History, Social and Cultural Anthropology and Philosophy at the University of Vienna. Her research interests are object studies and material culture, the history of consumption, the mechanization of the kitchen, environmental history, gender studies and the history of technology and everyday life.

Nina Lorkowski (M.A.) is a Ph.D. candidate at the Department of the History of Technology at the Technical University of Munich. Holding a degree in European Ethnology of the Philipps University Marburg, her research is focused on everyday technology as material culture and the interaction of consumption and technology. As research associate in the project "Objects of Energy Consumption," she wants to understand how the bathroom became a highly mechanized place that is characterized by energy-intensive consumption practices.

Nina Möllers (Ph.D.) is postdoctoral researcher at the Deutsches Museum and exhibition curator at the Rachel Carson Center in Munich. Her current research is concerned with the history of museums and exhibitions as mediators of technology and energy-intensive household consumption patterns. She studied in Palo Alto, CA, Tübingen and Nashville, Tennessee and received her Ph.D. from the University of Trier with a dissertation on the Creoles of Color in New Orleans. Before coming to the Deutsches Museum, she worked at the Museum of Technology and Labor in 
Mannheim. Her research interests are the cultural history of technology, gender studies, museum studies and the American South.

Mathias Mutz (Ph.D.) received his doctoral degree from the Georg-AugustUniversity in Göttingen in 2010. He was a fellow of the DFG Research Training Group "Interdisciplinary Environmental History" and held a position as Research Assistant at the Institute for Economic and Social History in Göttingen. Since October 2010, he is a Research Assistant at the Department of History at Humboldt University Berlin. He is especially interested in the environmental history of industrialization, transnational business history, and the history of time regimes.

Valentina Roxo (M.A.) received her master's degree in East European Studies from the Ludwig-Maximilians-University in Munich where she is currently a Ph.D. candidate in cooperation with the Rachel Carson Center. She also holds a Diploma in International Relations from the Urals State University, Russia and a Diploma Supplement in Scientific Communications. She worked as a Project Manager for the Financing of Energy Projects in Russia, Azerbaijan and Kazakhstan.

Tomas Moe Skjølsvold (M.A.) is a Ph.D. candidate at the Norwegian University of Science and Technology, Department of Interdisciplinary Studies of Culture. He holds a master's degree in sociology from the Department of Sociology and Political Science at the same university. His research interests revolve around science, technology and environmental issues with a current focus on renewable energy technologies and climate change.

Markus Spitzer (M.A.) received his master's degree in political science. He is currently researcher at the Austrian Institute for Sustainable Development in Vienna. His research interests are fuel poverty, new work, sustainable development and international development.

Karin Zachmann (Ph.D.) is Professor for the History of Technology at the School of Education at the Technical University Munich. She teaches a broad range of courses, including ones on Technology and the Cold War, Material Culture of Technological Society, and Technology and Foodways. MIT Press has recently published her jointly-edited (with Ruth Oldenziel) 
volume, Cold War Kitchen: Americanization, Technology, and European Users. Her current research focuses on the industrialization of food and foodways and includes transnational chapters on food irradiation. 


\section{Figures and Tables}

\section{Nina Möllers}

Figure 1: Hubert Howe Bancroft: The Book of the Fair. Chicago: Bancroft, $1893,410$.

Figure 2: Hubert Howe Bancroft: The Book of the Fair. Chicago: Bancroft, $1893,418$.

Figure 3: Pamphlet "Electricity at Work", Century of Progress 1933-34

World's Fair Collection, University of Chicago, Special Collections, http://century.lib.uchicago.edu/.

Figure 4: Pamphlet "Electricity at Work", Century of Progress 1933-34

World's Fair Collection, University of Chicago, Special Collections, http://century.lib.uchicago.edu/.

Figure 5: Cheryl Ganz: The 1933 Chicago World's Fair. A Century of Progress.

Urbana: University of Illinois Press, 2008, n. p.

Figure 6: Stanley Appelbaum, ed.: The New York World's Fair 1939/1940 in

155 Photographs by Richard Wurts and Others. New York: Dover, 1977, 57. Figure 7: Stanley Appelbaum, ed.: The New York World's Fair 1939/1940 in

155 Photographs by Richard Wurts and Others. New York: Dover, 1977, 62. Figure 8: This is America. Official United States Guide Book Brussels World's Fair 1958. New York: Office of the United States Commissioner General, 1958, 20.

Figure 9: This is America. Official United States Guide Book Brussels World's Fair 1958. New York: Office of the United States Commissioner General, $1958,10$.

\section{Sophie Gerber}

Figure 1: Bewag-Archiv/Vattenfall, Berlin.

Figure 2 and 3 : Archiv der HEA, Berlin. 


\section{Yves Bouvier}

Figure 1: SODEL/Médiathèque EDF/DR.

Figure 2: Havas Conseil/Réal: J\&C Clerfeuille/Médiathèque EDF/DR.

Figure 3: SODEL/Citeca. Réal: Jacques Monnet/Médiathèque EDF/DR.

Figure 4: Compagnie corporate/Telema/Médiathèque EDF/DR.

Figure 5: Callegari Berville/La Pac/Médiathèque EDF/DR.

Figure 6: Euro RSCG/Réal: Frédéric Planchon/Médiathèque EDF/DR.

Table 1: Henri Duhamel: “Un usage domestique: le cas de l'électroménager”, in: Henri Morsel, ed. Histoire de lélectricité en France, tome 3. Paris: Fayard, 1996, 924.

Table 2: Jean Dubois: "La société de consommation électrique", in: Henri Morsel, ed. Histoire de l'électricité en France, tome 3. Paris: Fayard, 1996, 578.

\section{Nina Lorkowski}

Figure 1: Bewag-Archiv/Vattenfall, Berlin.

\section{Mathias Mutz}

Figure 1: Mathias Mutz. Data from Time and Date AS. "The World Clock - Time Zones". http://www.timeanddate.com/worldclock, Accessed: 15.07.2011.

\section{Helena Ekerholm}

Figure 1: Motormännens Riksförbund: Motormännens gengasbok. Stockholm: Motormännens Riksförbund, 1940. Reprint, Stockholm, 1941, back cover.

Figure 2: Motormännens Riksförbund: Motormännens gengasbok. Stockholm: Motormännens Riksförbund, 1940. Reprint, Stockholm, 1941, 29.

\section{Silvana Bartoletto}

Figure 1: Data from Paolo Malanima: Pre-Modern European Economy. One Thousand Years (10 th $-19^{\text {th }}$ Centuries). Leiden: Brill, 2009.

Figure 2: Data from International Energy Agency (IEA): Energy Balances of OECD Countries, 2009 edition. Paris: OECD/IEA, 2009.

Figure 3: Data from International Energy Agency (IEA): Energy Balances of OECD Countries, 2009 edition. Paris: OECD/IEA, 2009. 
Figure 4: Data concerning energy intensity in England and Wales from Paul Warde: Energy Consumption in England and Wales. Naples: Consiglio Nazionale delle Ricerche, Istituto di Studi sulle società del Mediterraneo, 2007; for energy consumption in other countries, data from Ben Gales/Astrid Kander/Paolo Malanima/Mar M. Rubio: "North versus South. Energy Transition and Energy Intensity in Europe over 200 Years", in: European Review of Economic History 11 (2007), 219-51.

Figure 5: Data from International Energy Agency (IEA): Energy Balances of OECD Countries, 2009 edition. Paris: OECD/IEA, 2009; Silvana Bartoletto: “L'Energia. L'Intensità Energetica nei Paesi del Mediterraneo” in: Paolo Malanima, ed. Rapporto sulle Economie del Mediterraneo. Edizione 2010. Bologna: il Mulino, 2010, 213-37.

Figure 6: Data from International Energy Agency (IEA): Energy Balances of OECD Countries, 2009 edition. Paris: OECD/IEA, 2009; Silvana Bartoletto: "Energia e Ambiente in Europa (1800-2010)", in: Rivista di Studi sulla Sostenibilità 2 (2011), 59-78.

Table 1: For Italy, data from Silvana Bartoletto: "I Combustibili Fossili in Italia dal 1870 a oggi”, in: Storia Economica 2 (2005), 281-327 and Paolo Malanima: Energy Consumption in Italy in the $19^{\text {th }}$ and $20^{\text {th }}$ Centuries. Napoli: Consiglio Nazionale delle Ricerche, Istituto di Studi sulle Società del Mediterraneo, 2006; for England and Wales, data from Paul Warde: Energy Consumption in England and Wales. Naples: Consiglio Nazionale delle Ricerche, Istituto di Studi sulle Società del Mediterraneo, 2007; for Sweden, data from Astrid Kander: Economic Growth, Energy Consumption and $\mathrm{CO}_{2}$ Emissions in Sweden 1800-2000. Stockholm: Almqvist \& Wicksell International, 2002; for Netherlands and Spain, data from Ben Gales/Astrid Kander/Paolo Malanima/Mar M. Rubio: “North versus South. Energy Transition and Energy Intensity in Europe over 200 Years", in: European Review of Economic History 11 (2007), 219-51.

Table 2: Data for energy productivity from Silvana Bartoletto: "Energy and Economic Growth in Europe. The Last Two Centuries", in: Bruno Chiarini/Paolo Malanima, eds. From Malthus' Stagnation to Sustained Growth, Rivista di Politica economica (aprile-giugno 2010/2011), 57-75; data for energy consumption from Paolo Malanima: "The Path Towards the Modern Economy”, in: Bruno Chiarini/Paolo Malanima, eds. From Malthus' Stagnation to Sustained Growth, Rivista di Politica economica (aprile-giugno 2010/2011), 77-105; data for population and GDP from 
Angus Maddison: The World Economy. Historical Statistics. Paris: OECD, 2002 and Angus Madison: Contours of the World Economy, 1-2030 AD, Essays in Macro-Economic History. Oxford: University Press, 2008.

Table 3: Data from Silvana Bartoletto: "Energy and Economic Growth in Europe. The Last Two Centuries”, in: Bruno Chiarini/Paolo Malanima, eds. From Malthus' Stagnation to Sustained Growth, Rivista di Politica economica (aprile-giugno 2010/2011), 57-75. 